$$
\begin{aligned}
& \text { Universidade de Brasília - UnB } \\
& \text { Instituto de Psicologia - IP } \\
& \text { Departamento de Psicologia Clínica - PCL }
\end{aligned}
$$

Programa de Pós-Graduação em Psicologia Clínica e Cultura - PPG PsiCC

\title{
"Ela não precisava chamar a polícia...": anestesias relacionais e duplo-vínculos na perspectiva de homens autores de violência conjugal
}

\author{
FABRÍCIO LEMOS GUIMARÃES
}

TESE DE DOUTORADO

Brasília

Dezembro 2015 
Universidade de Brasília - UnB

Instituto de Psicologia - IP

Departamento de Psicologia Clínica - PCL

Programa de Pós-Graduação em Psicologia Clínica e Cultura - PPG PsiCC

\section{"Ela não precisava chamar a polícia...": anestesias relacionais e duplo-vínculos na perspectiva de homens autores de violência conjugal}

Doutorando: Fabrício Lemos Guimarães

Tese apresentada ao Programa de PósGraduação em Psicologia Clínica e Cultura como requisito parcial para obtenção do grau de Doutor em Psicologia Clínica e Cultura.

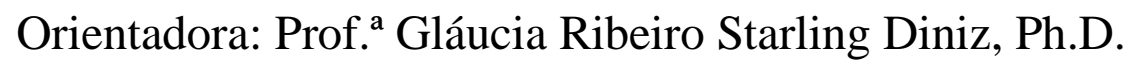

Brasília

2015 


\author{
$\checkmark$ \\ Universidade de Brasília - UnB \\ Instituto de Psicologia - IP \\ Departamento de Psicologia Clínica - PCL \\ Programa de Pós-Graduação em Psicologia Clínica e Cultura - PPG PsiCC
}

"Ela não precisava chamar a polícia...": anestesias relacionais e duplovínculos na perspectiva de homens autores de violência conjugal

Banca Examinadora:

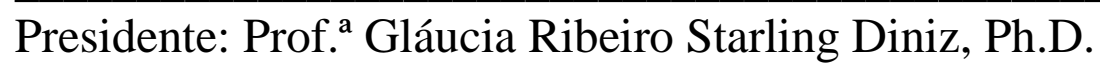

Programa de Pós-Graduação em Psicologia Clínica e Cultura - PPG PsiCC/PCL/IP/UnB

Membro Externo: Prof ${ }^{\mathrm{a}}$. Dr ${ }^{\mathrm{a}}$ Ana Maria Fonseca Zampieri

Universidad del Salvador - USAL

Membro Externo: Prof. Dr. Fábio Pereira Angelim

Universidade Paulista - UNIP / Superior Tribunal de Justiça - STJ

Membro Interno: Prof. ${ }^{a}$ Dr. ${ }^{a}$ Ângela Maria de Oliveira Almeida

Programa de Pós-Graduação em Psicologia Social, do Trabalho e das Organizações - UnB

Membro Interno: Prof. Marcelo da Silva Araújo Tavares, Ph.D.

Programa de Pós-Graduação em Psicologia Clínica e Cultura - PPG PsiCC/PCL/IP/UnB

Membro Suplente: Prof. ${ }^{a}$ Dr. ${ }^{a}$ Miriam Cássia Mendonça Pondaag

Instituto de Educação Superior de Brasília - IESB / Secretaria de Políticas para Mulheres, Igualdade Racial e Direitos Humanos - SEMIDH/GDF 
Inimigos: não lhes dou a menor importância. Os desejos que me pegam são os desejos das pessoas que amo - anzóis na carne (...) Embora não saibamos, o amor também mata.

Alves, Rubens (2011). Variações sobre o prazer: Santo Agostinho, Nietzsche, Marx e Babette. São Paulo: Editora Planeta do Brasil. 


\section{Dedicatória}

"De todo amor que eu tenho, metade foi tu que me deu..." (Música: Dona Cila-Maria Gadu)

Ao meu querido e amado pai Vanuil (in memorian), Dedico essa tese com muito amor, carinho e saudade.

Só tenho boas lembranças desse grande homem. Ele é uma referência para toda a nossa família por ter sido um ótimo pai, marido, filho, irmão, sogro, amigo e avô.

É o inesquecível "Vô IL".

Tenho certeza que de onde estiver, ele estará muito feliz em receber essa homenagem por meio de um trabalho que busca contribuir para a paz social. Ele que sempre criou os/a filhos/a com tanto amor e carinho, foi um companheirão para minha mãe, amou tanto os animais, as plantas e as crianças...

Só nos deixou exemplos de amor.

Já se passaram cinco anos sem a sua presença física entre nós, mas o amor por ele nos ensinou a superar a dor da saudade inicial e transformá-la em uma saudade gostosa, repleta de ótimas lembranças de todos os momentos maravilhosos que passamos juntos nessa caminhada da vida.

Eu e meus irmãos somos privilegiados por Deus ter nos presenteado com os melhores pais do mundo.

Só temos que agradecer a oportunidade de conviver e aprender tanto com uma pessoa tão sábia, simples,

generosa, humilde e amada como o Vanula.

Ele nos ensinou a lidar com os diversos obstáculos da vida, sempre com muito amor e humildade. Como diz a Maria Gadu na música, ele pôde ir tranquilo, pois "o seu rebanho está pronto..."

De onde estiver, pai querido, receba essa singela homenagem com muito amor, carinho e saudade.

Saiba que as lágrimas que caem nesse momento são de uma saudade boa, alegre e de gratidão...

Eu te amo muito!!!

"Só enquanto eu respirar, vou me lembrar de você..." (Música: $O$ anjo mais velho - O Teatro Mágico) 


\section{Agradecimentos}

Eu agradeço a Deus por todas as bênçãos recebidas.

Aos homens que participaram da pesquisa. Sou extremamente grato por ter o privilégio de vivenciar em meus trabalhos e estudos com pessoas em situação de violência como surge tanta competência em situações tão adversas. Eu aprendo diariamente verdadeiras lições de vida.

À minha esposa - Elcia Lemos Guimarães. Minha companheira, fonte de inspiração e de determinação. Como eu sou feliz por amar e ser amado por uma pessoa tão especial.

À minha família - mãe, pai, Biscoitão, Raquel, Gui, Sissia, Serginho, Tuca e Serjão. Eles/as sempre me apoiam com muito amor e carinho. Eu amo muito minha família!!!

À minha querida orientadora, Prof. a Gláucia Diniz, por toda atenção, carisma, competência e acolhida desde a época da graduação. É uma verdadeira "mãe acadêmica". Eu conquistei uma grande amiga, madrinha e companheira de caminhada rumo a uma sociedade sem tanta violência. Agradeço ao meu padrinho, Prof. Marcelo Tavares, que tenho profunda admiração pela pessoa e pelo profissional que é. Eles formam um casal muito admirável e amado. Eles são uma referência para mim.

A toda equipe/família SEPSI/SERAV do TJDFT. Agradeço especialmente à equipe SERAV Ceilândia - Pat, Raquel, Luiz, Cris Vilela, Chris Carvalho, Carla, Alexandre e as nossas queridas ex/estagiárias. Como eu sou grato por conviver, aprender e amar vocês. São verdadeiros/as amigos/as que levarei para toda a minha vida. Amo vocês!!!

À Equipe do NEGENPSICC: Dani, Marcela, Celana, Timóteo, Claudinha, Greisy, Luiz Fernando, Aline, Marília, Poli, Denise. E, em especial, à velha guarda: Nayara, Luiz Henrique, Fabinho, Miriam, Cris, Lu.

À equipe do Projeto Maria da Penha do NPJ/UnB de Ceilândia. Especialmente à Professora Ela, Soraia, Andre, Nay.

Às queridas Professoras Lourdes Bandeira e Mariza Veloso, que ministraram a disciplina da Pós em Sociologia: "Pensamento Social Brasileiro e Relações Sociais de Gênero". Essa disciplina ampliou minha visão sobre os estudos feministas. Sou muito grato por ter esse novo olhar para esses movimentos tão lindos e humanos, aprendi a respeitar e admirar ainda mais a luta pela igualdade de gênero.

À Prof. ${ }^{a}$ Sheila Murta, à Dra Larissa Nobre e demais membros do Grupo de Estudos em Prevenção e Promoção da Saúde no Ciclo de Vida GEPPSVida/UnB - pelas parcerias nos projetos de prevenção à violência com jovens. Eu quero me aproximar cada vez mais de vocês, pessoas tão competentes e humanas.

Ao Prof. Adriano Beiras, que conheci recentemente e aprendi a admirar tanto enquanto profissional e ser humano. Agradeço imensamente todo o apoio, inclusive de ter enviado material bibliográfico extraordinário, que faz parte da base fundamental desse estudo.

À rede de mulheres de Luziânia pela parceria na realização do sonho de implementar o CEAM de nossa querida cidade de Luziânia. Agradeço imensamente à Dra Marina, Vereadora Cassiana, Zete (presidente CONDIM), Dra. Tereza (coordenadora CEAM), Ângela, Joyce, Irmã Ilma e Sara (equipe CEAM), Comandante Wellington (Patrulha da Mulher), Prefeito Cristovão, Professoras Glaucia Diniz e Ela Wiecko. O projeto do CEAM foi fruto de iniciativa e articulação da $6^{\text {a }}$ Promotoria de Justiça de Defesa dos Direitos da Mulher e fez parte de nossas atividades do doutorado. Realizamos um sonho e vamos continuar juntos/as nessa caminhada para revolucionar a nossa cidade em prol da paz social.

Agradeço imensamente a participação dos/as facilitadores/as da Capacitação Continuada ( $2^{\mathrm{a}}$ Etapa) do Curso de capacitação "Violência, gênero, família e conjugalidade: interlocuções interdisciplinares para uma prática emancipadora": Prof.a Gláucia Diniz; Dra. Marina Mello; Dr. Ben Hur Visa; João Wesley Domingues; André Luiz Oliveira; Nayara Teixeira Magalhães; Dra. Ana Cristina; Cabo Gmayeel Wistemann; Luiz Henrique Aguiar; Dra. Larissa Nobre; e Danielle 
Soares de Macedo. Eles/as aceitaram contribuir com muita boa vontade com o nosso projeto de capacitação para os/as profissionais da Rede de Luziânia após a inauguração do CEAM.

Ầ equipe da Associação Brasileira de Ajuda Humanitária Psicológica - ABRAPAHP. Agradeço em especial à querida, admirada e amada Prof. ${ }^{a}$ Dr. ${ }^{a}$ Ana Zampieri. A ABRAPAHP é a realização de um sonho pessoal de atuar em uma psicologia realmente voltada à humanidade. Eu sou muito feliz e grato por fazer parte dessa equipe tão humana em prol das pessoas vítimas das tragédias e catástrofes socionaturais. Eu amo vocês!!!

Ao Mariano Pedroza e Valéria Silveira (CENTRAR) por me estimularem a entrar no belo e libertador mundo do TRE - Exercícios para Liberação do Estresse e Traumas. O TRE é a minha nova paixão e incentivo do autocuidado como primordial para a nossa atuação enquanto cuidadores. O TRE é um estímulo adicional para atuar de forma solidária junto à sociedade. Agradeço às pessoas queridas que aceitaram participar do meu trabalho voluntário com um Grupo de TRE/Autocuidado em Luziânia. Eu cresci muito enquanto profissional e ser humano nesse período graças à confiança de vocês.

À querida amiga Mariana Juras, companheira de todas as horas e de todos os momentos. Estamos juntos nessa caminhada desde a graduação e perpassamos muitas estradas em comum (graduação, pós-graduação - como aluno/a e professor/a, mestrado, doutorado, NAFAVD, TJDFT etc.) em prol da paz social. Agradeço, especialmente, o envio de preciosas referências bibliográficas durante o doutorado sanduíche dela nos EUA.

Aos/às alunos/as da Pós do IESB e UCB. Especialmente do estágio em violência conjugal e de minhas orientandas de TCC: Karine, Isaura, Adriana e Marli.

Ao Instituto de Psicologia da UnB, que me acolheu desde a graduação, mestrado, e, atualmente, no doutorado. O contato com a Psicologia mudou minha vida.

Ao SERAV e ao NAFAVD pela autorização para realização da pesquisa. Em especial, às queridas Michelle Tusi, Marília Lobão (SERAV), Maísa Guimarães e Silvania Temóteo (NAFAVD). Agradeço imensamente aos técnicos/as, especialistas, agentes sociais e estagiárias do SERAV e NAFAVD pelo apoio, parceria e disponibilidade para me ajudar na segunda etapa da coleta de dados nos diversos grupos: Juliana, Miguel (SERAV), Rodrigo, Sara, Victor, Ádila, Mariana, Cheila, Jean, Tatiane, Leandra e Raissa (NAFAVD). Esse apoio foi fundamental para a pesquisa. Foi um momento de muita aprendizagem, troca de experiências e grande crescimento enquanto pesquisador e profissional.

Ao CJM/TJDFT pela parceria e incentivo de sempre. Especialmente ao Dr. Ben Hur, Dr. Bismarck, Cris, João e Tarci. É muito bom conviver e aprender tanto com vocês. A determinação e o empenho de vocês são extremamente incentivadores.

Aos policiais do Provid/PMDF. Agradeço especialmente ao Capitão Odorico, Sargento Flávio, Sargenta Camarano e Cabo Gmayeel. Sou muito grato por ter conhecido policiais tão humanos, competentes e empenhados/as com a causa. Espero ampliar cada vez mais nossa parceria.

À Editora Ediouro, pela doação de 3 exemplares de livros "Mas ele diz que me ama" para a realização dessa pesquisa.

Ao tio Vantuil e à Tia Erta pelo apoio e incentivo de sempre. Vocês são um dos grandes responsáveis por essa minha caminhada acadêmica. Só cheguei até aqui porque o Colégio Vovó Olívia me proporcionou uma base sólida de ensino. Agradeço especialmente alguns/mas professores/as que me incentivaram e inspiraram tanto a decidir por essa vida acadêmica: Vantuil Júnior (Juninho), Álvaro, Alex, Valim, Rafael, Celeste, Pedro e Jheny.

Aos/às queridos/as professores/as que aceitaram participar da banca de qualificação e da banca final: Ana Zampieri, Fábio Angelim, Ângela Almeida, Marcelo Tavares, Miriam Pondaag. Recebam os meus sinceros agradecimentos com muito carinho e admiração pelas valiosas críticas e sugestões para melhoria desse trabalho. Em especial, ao professor Fábio pelas sugestões para a segunda etapa da pesquisa.

Ao meu amigo e parceiro de todas as horas, "Max, aquele Max", pela diagramação das imagens do segundo questionário. Nossa irmandade vai muito além da organização da lendária 
LuziCerva. Agradeço imensamente pelo capricho na adaptação do instrumento. Ao professor Marcelo Tavares pelas dicas técnicas para fechamento das imagens para o questionário.

Aos meus amigos e às minhas amigas, em especial ao "Povo 100 limite" de Luziânia e aos Psicoloucos da UnB. O convívio com vocês me proporciona o estímulo necessário para ter a imensa paixão e o entusiasmo pela vida e por meu trabalho. O verdadeiro contato renova a energia para a manutenção da saúde mental e a alegria de sempre. A nossa amizade de aproximadamente 12 anos (Psicoloucos) e 20 anos (Povo 100 Limite) é uma das maiores conquistas de minha vida. Vamos continuar "quebrando tudo" com muito amor por toda a vida. 
Guimarães, F. L. (2015). “Ela não precisava chamar a polícia...”: anestesias relacionais e duplovínculos na perspectiva de homens autores de violência conjugal. Tese de doutorado. Instituto de Psicologia, Universidade de Brasília, Brasília.

\section{Resumo}

Essa pesquisa qualitativa teve o objetivo de identificar como homens autores de violência conjugal encaminhados pela Justiça para intervenção psicossocial manifestaram indícios de anestesias relacionais e de dimensões duplo-vinculares que favorecem processos de naturalização das agressões nas dinâmicas conjugais marcadas pela violência. Os instrumentos utilizados foram o livro "Mas ele diz que me ama"; dois questionários; ficha de evolução e formulários de acolhimento do SERAV e do NAFAVD; e "Controle de empréstimo dos livros". A pesquisa foi realizada em duas etapas. Os participantes da primeira etapa foram 13 homens que estavam em acompanhamento psicossocial no SERAV/TJDFT. Os participantes da segunda etapa foram 45 homens em acompanhamento no NAFAVD/SEM/GDF (37) e no SERAV/TJDFT (oito). A primeira etapa consistiu em estudo piloto para fornecer subsídios para elaboração do questionário para a segunda. Na primeira etapa, os participantes realizaram leitura do livro e responderam o questionário durante a semana para realização de reflexão grupal sobre as suas respostas no segundo encontro. $\mathrm{O}$ procedimento da segunda etapa foi adaptado para ser aplicado em um único encontro grupal - que consistiu em leitura conjunta de resumo do livro, seguida de preenchimento individual do questionário e de reflexão grupal. A natureza qualitativa da pesquisa nos levou a privilegiar a análise de conteúdo das respostas aos questionários preenchidos pelos participantes. As respostas dos participantes mostraram um continuum de naturalização da violência ao comparar as vivências pessoais com a história do livro. A maioria dos participantes da segunda etapa apresentou respostas que apontaram as próprias vivências como menos graves que a história do livro: 16 homens negaram totalmente as agressões ao não conseguirem perceber aspectos da violência em suas relações; 14 participantes perceberam alguma dimensão da violência, mas minimizaram o seu impacto; 14 homens se desresponsabilizam - perceberam a violência no relacionamento, mas a justificaram ou externalizaram sua responsabilidade. Foram estabelecidas quatro categorias de anestesias que os próprios homens autores de violência criaram e/ou consideraram como mais influentes em suas vivências: desresponsabilização do homem; minimização da violência; negação da violência; e início do processo de reconhecimento da violência. Na primeira etapa, 33 dentre as 35 anestesias listadas no livro foram marcadas pelo menos uma vez pelos participantes. Os homens conseguiram identificar 19 anestesias relacionais em suas próprias vivências sem os estímulos das anestesias do livro. Na segunda etapa, 30 dentre as 31 anestesias listadas no questionário criado a partir dos dados da primeira etapa foram marcadas pelo menos uma vez. Uma anestesia foi citada por mais da metade dos 45 participantes: "Ela não precisava chamar a polícia". A análise dos títulos dados pelos homens à sua própria história revelou características duplo-vinculares dos relacionamentos. Quatro categorias de paradoxos entre o discurso de naturalização da violência e a presença de agressões na relação foram identificadas: desresponsabilização dos homens; minimização; negação; início do processo de reconhecimento da violência. Essas respostas revelaram que a história do livro "Mas ele diz que me ama" pode contribuir para a compreensão das vivências de homens autores de violência, facilitar a manifestação da naturalização da violência e apontar indícios de anestesias relacionais e características duplo-vinculares nas dinâmicas conjugais. Essa proposta metodológica favoreceu a escuta de homens de forma diferenciada e propiciou que eles mesmos conseguissem iniciar o processo de autorresponsabilização, de conscientização de anestesias e de paradoxos da dinâmica relacional marcada e estruturada pela violência. Esse é um passo estratégico para a superação da violência de gênero contra a mulher nas relações conjugais.

Palavras-chaves: Violência conjugal; gênero; masculinidades; duplo-vínculo; anestesia relacional. 
Guimarães, F. L. (2015). "She did not need to call the police...": relational anesthesia's and double-binds from the perspective of men authors of marital violence. Doctoral dissertation. Institute of Psychology, University of Brasília, Brasília, Brazil.

\begin{abstract}
This qualitative research had the objective to identify how men referred to the judicial system to participate in a mandated psychosocial intervention due to their involvement in violent marital relationships manifested relational anesthesia's and double-binds that favor processes of naturalization of the aggressions in marital dynamics structured by violence. The instruments were the book "But he says he loves me...", two questionnaires, an intake and an evolution form of SERAV and NAFAVD, and a "Book lending Control Form". The data collection was divided in two phases. The participants of the first phase were 13 men that were referred to SERAV/TJDFT. The participants of the second phase were 45 men referred to NAFAVD/SEM/GDF (37) and to SERAV/TJDFT (8). The first phase consisted of a pilot study to subsidize the elaboration of the questionnaire used in the second phase. In this first phase the participants read the book and were given a week to answer a questionnaire that was discussed at a group reflection meeting. This procedure was adapted to take one group meeting on the second phase. It consisted on a group reading of a summary of the book, followed by individual filling up of the questionnaire and a group reflection. Due to the qualitative nature of the research, content analysis was used to interpret the participant's responses to the questionnaires. The answers revealed a continuum of naturalization of the violence when the participants compared their personal experiences with the experiences of the characters of the book. The majority of participants of the second gave answers that indicated that their experiences were less serious/graves than those of the characters in the story narrated in the book: 16 participants on both phases totally denied the aggressions and were not able to perceive any violence present in their relationships; 14 men were able to identify some violence but minimized its impact; 14 men denied having any responsibility for the violence - they perceived the presence of violence in the relationship, but justified or externalized the responsibility. Four categories of anesthesias were identified by the men as being most influential in their experiences: denial of having any responsibility for the violence; minimization of the violence; total denial of the presence of violence; initial recognition of the presence of violence. On the first phase, 33 among the 35 anesthesias listed in the book were marked at least one time by the participants. The men were able to identify 19 relational anesthesias in their own experiences apart from the stimulus offered by the book. On the second phase, 30 of the 31 anesthesias listed in the questionnaire created based on the data gathered on the first phase were checked at least one time. One anesthesia was cited by more than half of the 45 participants: "She did not need to call the police". The analyses of the titles given by the men to their own story reveled the double bind characteristics of the relationships. Four categories of paradoxes were identified amidst the discourse of naturalization of the violence and of the presence of aggressions in the relationship: lack of responsibility for the violence on the part of the men; minimization; negation; indication of an initial process of recognition of the violence. The data revealed that the story of the book has the potential to help men in violent relationships to understand their own situation; to facilitate manifestations of the naturalization of violence; to point out the presence of relational anesthesias and double-binds in the marital dynamics. This methodological approach showed the following benefits: 1. it helped professionals in the judicial system to listen to men in a differentiated perspective; 2 . it allowed the men to initiate the process of self-responsibilization for their acts; 3 . they began to gain insight of the anesthesias and paradoxes present in the relational dynamic structured around violence. These results represent an strategic step towards the recognition and superation of gender violence against women in marital relationships.
\end{abstract}

Key-words: Marital Violence; gender; masculinities; double-bind; relational anesthesia. 
Resumo. ix

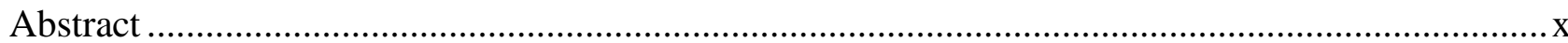

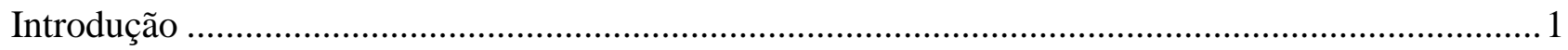

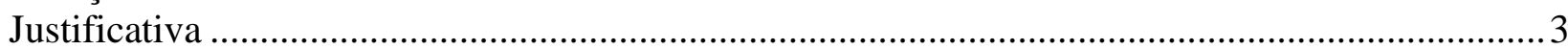

Pesquisas com homens autores de violência.................................................................... 5

Pesquisas da Psicologia sobre homens autores de violência.................................................. 8

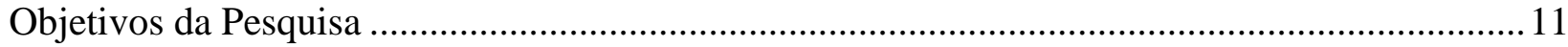

Capítulo 1 - Gênero, masculinidades e naturalização da violência conjugal ................................... 14

Masculinidades: evolução histórica do conceito..................................................................... 15

Socialização de gênero e vulnerabilidades masculinas para violências ........................................ 21

Vulnerabilidade masculina para a violência conjugal............................................................24

Violência, masculinidades e os diferentes estilos de conjugalidade ...........................................27

Homens na violência conjugal: de oponentes a agentes de mudança ......................................... 33

Dimensões da violência conjugal: necessidade de também enxergar os homens ......................... 37

Mitos, desresponsabilização de homens e culpabilização de mulheres ........................................ 41

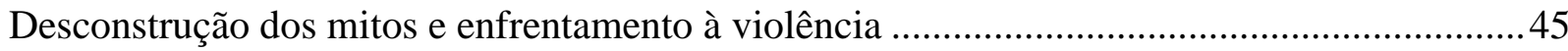

Repensando masculinidades, mitos sociais e naturalização da violência .................................... 46

Capítulo 2 - Violência conjugal e perspectiva sistêmica: aprisionamentos de homens autores ........ 49

Homens, violência conjugal e perspectivas sistêmicas ...............................................................50

Anestesias relacionais: homens também não veem que não veem a violência.............................51

Mitos e naturalização da violência: bases sociais para instalação de anestesias relacionais ......52

Anestesias relacionais e dificuldade de homens em perceber a violência .................................55

Anestesias relacionais e seu papel na conjugalidade marcada pela violência ...........................57

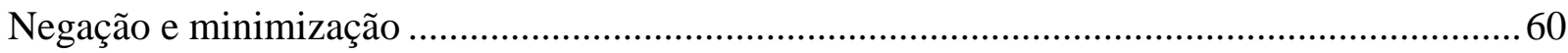

Desresponsabilização: justificação e externalização da violência ............................................64

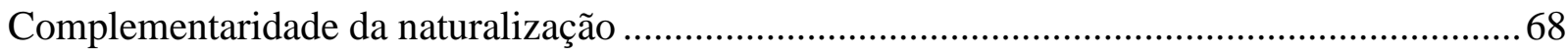

Teoria do duplo-vínculo e o aprisionamento de homens e mulheres à relação ............................69

Teoria do Duplo-Vínculo: breve contextualização ................................................................... 70

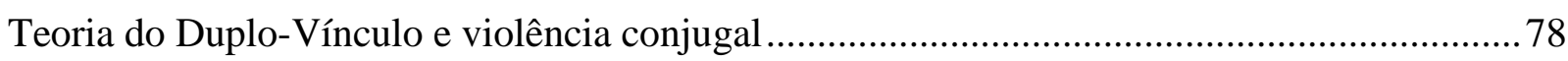

Perspectiva sistêmica e aprisionamentos de homens autores.................................................... 92

Capítulo 3 - Pesquisas, políticas e intervenções com homens autores de violência .........................95

Intervenção com homens: dimensão essencial para o enfrentamento da violência .......................95

Panorama internacional das intervenções com homens ............................................................ 98

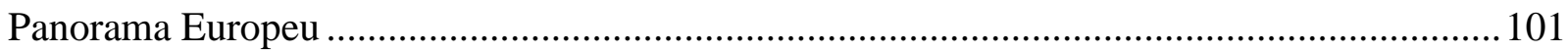

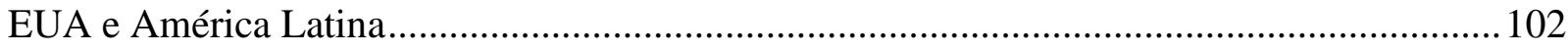

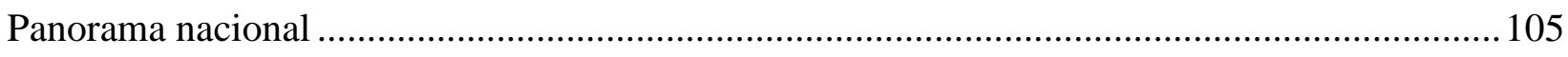

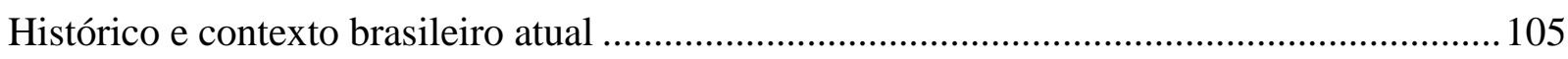

Lei Maria da Penha e masculinidades: como a lei enxerga os homens ................................. 109

Características dos programas de atenção aos homens no Brasil ..............................................117 
Iniciando a caminhada para além da responsabilização...................................................... 118

Contextualização dos programas brasileiros de atenção aos homens ....................................119

Perspectivas futuras: aproximar para compreender masculinidades......................................... 124

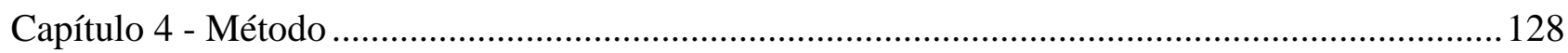

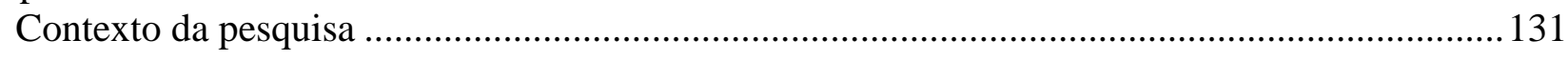

Serviço de Assessoramento aos Juízos Criminais - SERAV .............................................. 132

Núcleo de Atendimento às Famílias e Autores de Violência Doméstica - NAFAVD ............. 134

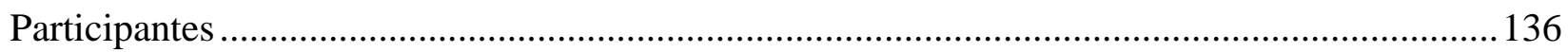

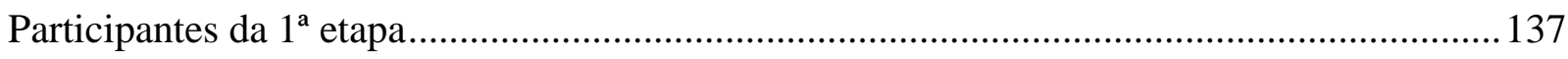

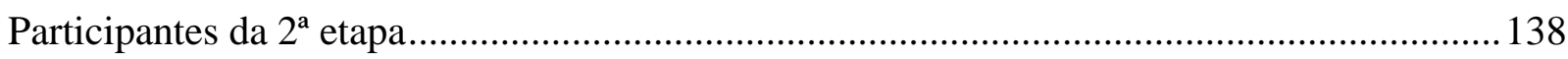

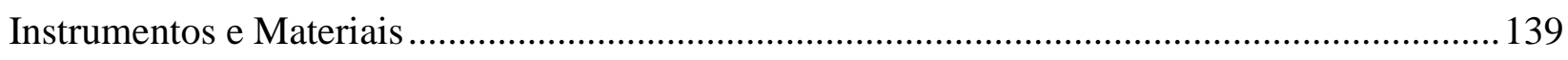

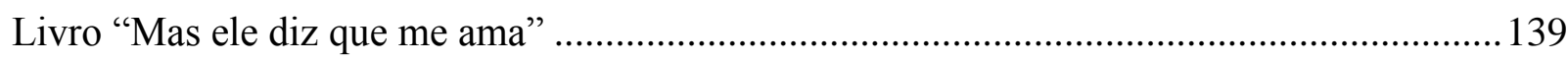

Questionários sobre o Livro "Mas ele diz que me ama" ..................................................... 139

Ficha de evolução do Grupo Misto do SERAV ...................................................................... 142

Formulários de acolhimento do SERAV e do NAFAVD ...................................................... 142

Controle de Empréstimo do Livro ................................................................................... 142

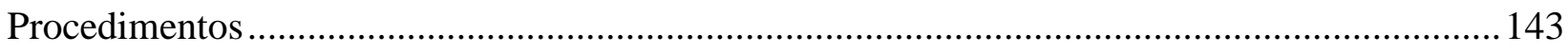

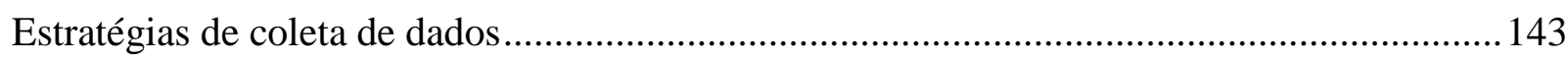

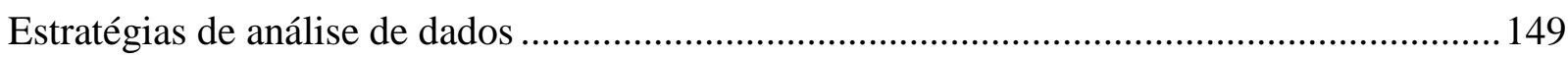

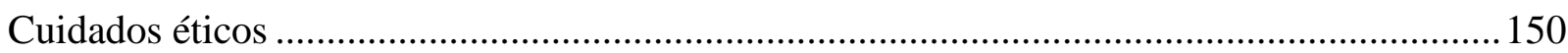

Capítulo 5 - Resultados: Duplo-vínculos e anestesias relacionais na perspectiva de homens ........ 153

Contextualização das conjugalidades dos homens participantes ............................................ 154

Breve panorama das vivências conjugais dos participantes................................................... 164

Da história do livro às vivências dos homens autores de violência ........................................... 170

Sentimentos despertados pelos participantes com a leitura do livro..................................... 173

Naturalização da violência na comparação entre as vivências do livro e as dos homens .........178

Anestesias relacionais de homens autores de violência ...................................................... 189

Duplo-vínculos e nomeação da violência conjugal pelos homens autores ..............................208

Complementaridade das vivências de homens e mulheres .......................................................221

Sentimentos despertados pelos/as participantes com a leitura do livro ..................................221

Comparação entre a história do livro e as vivências dos homens e das mulheres ...................222

Reflexão sobre as anestesias relacionais dos homens e das mulheres ....................................226

Duplo-vínculos e nomeação da violência conjugal pelos homens e pelas mulheres ................230

Capítulo 6 - Compreensão das masculinidades como meio de superar a violência conjugal ..........234

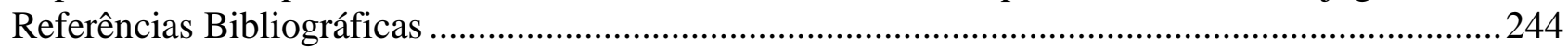

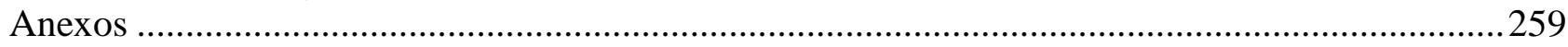




\section{Introdução}

Olha só, que cara estranho que chegou

Parece não achar lugar

No corpo em que Deus lhe encarnou

Tropeça a cada quarteirão

Não mede a força que já tem

Exibe à frente o coração

Que não divide com ninguém

(...)

Faz parte desse jogo

Dizer ao mundo todo

Que só conhece o seu quinhão ruim

É simples desse jeito

Quando se encolhe o peito

E finge não haver competição

É a solução de quem não quer

Perder aquilo que já tem

E fecha a mão pro que há de vir

(Música: Cara estranho - Los Hermanos)

Trabalhar com homens, mulheres e casais em situação de violência conjugal constitui um enorme desafio e, simultaneamente, uma valiosa oportunidade de aprendizado. Nesses 10 anos de atuação na área como servidor público, professor e pesquisador, acredito que essa temática sempre será desafiadora, instigante e difícil. Ao mesmo tempo, oferece ampla possibilidade de crescimento pessoal e profissional por nos possibilitar aprender muito com as pessoas atendidas. Apesar da presença de violências nas suas relações, esses homens e mulheres são seres humanos maiores que seus problemas. Eu me sinto privilegiado por vivenciar grandes histórias de resiliência, transformação e superação. Verdadeiras lições de sabedoria e de vida. Essa tese é uma forma de agradecer e retribuir com muito amor e gratidão a tudo que recebi das pessoas que atendi nesse período.

A literatura da área e as narrativas das pessoas que acompanhei indicam que muitos homens e muitas mulheres cujas relações são marcadas pela presença de violência conjugal não conseguem enxergar as dimensões desse problema e o seu impacto na relação e na vida familiar. Eles tampouco conseguem nomeá-las. O fato é que eles e elas tendem a ignorar, negar, silenciar, minimizar ou justificar as consequências das várias formas de violências praticadas (Angelim, 2009; Diniz \& Pondaag, 2004, 2006; Pondaag, 2003, 2009).

A dificuldade que as pessoas têm de perceber e nomear a violência em sua dinâmica relacional constitui um desafio clínico e de pesquisa que não pode ser ignorado. Muitos homens e mulheres em situação de violência conjugal que são encaminhados/as pela Justiça para o acompanhamento psicossocial também naturalizam a gravidade e o risco das violências, apesar de 
terem passado por essas experiências em suas conjugalidades. Esse processo de naturalização engloba a negação, a minimização e a desresponsabilização da violência.

O contato com o livro "Mas ele diz que me ama: graphic novel de uma relação violenta" (Penfold, 2005/2006) foi uma oportunidade e um passo importante para nos ajudar a lidar com o desafio de auxiliar pessoas encaminhadas pela Justiça a saírem do processo de naturalização para a possibilidade de conscientização acerca da violência. O livro é ilustrado e escrito em formato de história em quadrinhos, o que facilita consideravelmente a leitura, o interesse e a identificação por parte do/a leitor/a.

O livro foi utilizado inicialmente como ferramenta clinica em alguns atendimentos individuais com mulheres que mostraram imensa dificuldade em falar sobre suas experiências de violência. $\mathrm{O}$ livro era entregue à mulher com o pedido de que ela fizesse a leitura durante a semana. Ao retornar para o atendimento seguinte ficava evidente que a leitura produzia um forte impacto na maioria das mulheres vítimas de violência - elas passavam da naturalização para a possibilidade de conscientização e nomeação da violência.

A história da personagem incitava reflexões e provocava uma mudança na percepção e na narrativa das mulheres. O drama de outra mulher permitia a elas a identificação e, consequentemente, o falar sobre sua própria história conjugal marcada pela violência. A partir da constatação de que a leitura do livro permitia à mulher sair do estado de negação, surgiu a ideia de uma pesquisa de mestrado para utilizar esse livro nos atendimentos em grupo e construir um método mais consistente para a sua aplicação nos atendimentos psicossociais.

A pesquisa de mestrado teve por objetivo refletir sobre o impacto da história de uma vítima na vivência de violência conjugal de outras mulheres, por meio da leitura, resposta a questionário e reflexão grupal sobre o livro "Mas ele diz que me ama". As participantes foram 20 mulheres encaminhadas pela Justiça para acompanhamento psicossocial. Elas identificaram-se com a história da personagem e experienciaram a leitura do livro como estímulo para conscientização da realidade vivida como violenta; como forma de empoderamento pessoal e de adoção de estratégias de mudanças (Guimarães, 2009).

Várias participantes mencionaram a importância de outras mulheres e os seus ex/parceiros terem acesso ao livro e à intervenção psicossocial. Elas revelaram a vontade do ex/companheiro também ter contato com essa vivência. As falas retiradas da dissertação "Mas ele diz que me ama...': impactos da história de uma vítima na vivência de violência conjugal de outras mulheres" (Guimarães, 2009, p. 17) deixam clara essa vontade:

Se a gente que sofre a violência se identificou com essa historia, não seria o caso também do autor da violência ler também? Para se conscientizar que o que ele está fazendo e praticando é violência. Ele tem que se conscientizar e mudar. Não 
seria o caso? Então se colocasse para eles ler também eles também iam se identificar com a história, para ver que o que eles praticam é violência. Não precisa ser somente a violência física, a psicológica também. E tentar mudar também, procurar um tratamento.

Bom eu me identifiquei bastante. Tem muitos trechos igual o que eu já passei, entendeu? Tem certos trechos, muitas páginas, que a gente fica dolorosa, principalmente em relação às crianças. E eu gostei, achei bastante interessante, só que assim, geralmente só a gente mulher tem esse acesso, acho que principalmente os homens deviam ler, para ter pelo menos a capacidade de entender e compreender o que a gente passa (...) Evitaria muitas coisas, eles teriam outra ideia do que é viver a dois, porque às vezes eles podem até estar fazendo aquilo com a gente e nem vê.

E acharia interessante também ele ler. Eles acham que tem algumas coisas que são exageros nosso, ou como é que se diz, que eles não dão muita importância, no livro mostra como a gente sofre. Mas de cem tiraria alguns que acharia interessante, tem a questão do machismo né.

Rosalind Penfold, autora do livro "Mas ele diz que me ama" (Penfold, 2005/2006), corrobora a ideia dessas participantes. Ela deixa claro no livro essa expectativa de que sua história possa vir a ajudar os homens:

Comecei a ter esperanças de que meus desenhos pudessem ajudar os outros - nem que seja uma pessoa só - a perceber os danos terríveis e duradouros que tal ambiente causa em uma família (...) embora os desenhos sejam meus, infelizmente o padrão de abuso que eles representam são muito comuns (...) Tenho esperanças de que meus desenhos ajudem homens e mulheres a identificar os sinais de alerta que indicam abuso (Penfold, 2005/2006, p. xi).

A estratégia utilizada na pesquisa de mestrado mostrou seu potencial e utilidade como método de pesquisa e como modelo de intervenção clínica com mulheres (Guimarães, 2009). Identificamos a potencialidade de também aplicar e adaptar o método da pesquisa de mestrado aos homens autores de violência, o que originou essa pesquisa de doutorado.

\section{Justificativa}

A violência conjugal é um fenômeno grave e complexo. É considerada uma violação de direitos humanos e um problema de saúde pública (Fávero, 2010; Lima \& Büchele, 2011; Macedo, 2013; Separavich \& Canesqui, 2013). Essa violência envolve aspectos culturais, sociais, políticos, legais, educacionais, de saúde, comunitários, familiares, relacionais, individuais e psicológicos (Angelim, 2004; Ávila, Machado, Suxberger \& Távora, 2014; Krug et al., 2002; Santos \& Moré, 2011; Silveira, Medrado \& Rodrigues, 2009). Conhecer esse fenômeno a fundo significa enfrentar o desafio de entender as diversas dimensões da relação conjugal marcada pela violência. 
Na pesquisa do mestrado fomos buscar no livro que narra e ilustra a história de uma vítima o elemento potencializador de reflexões sobre a experiência de violência conjugal de outras mulheres. A estratégia metodológica utilizada - leitura do livro seguida de reflexão grupal - permitiu o surgimento de um contexto de identificação com a personagem que levou a comparações entre as histórias pessoais das participantes e a da personagem do livro; favoreceu a percepção de suas próprias anestesias relacionais; contribuiu para a conscientização e a nomeação da violência vivenciada (Guimarães, 2009). Anestesias relacionais são ideias, sentimentos e ações que contribuem para a permanência de mulheres e de homens na situação de violência conjugal (Ravazzola, 1997, 1998, 2015). Esse conceito será melhor definido e discutido no Capítulo 2 dessa tese.

Percebemos, então, a necessidade de realizar estudo semelhante com homens autores de violência igualmente encaminhados pelo sistema de Justiça. O objetivo desse estudo foi, portanto, verificar o potencial do livro "Mas ele diz que me ama" (Penfold, 2005/2006) para ajudar homens autores de violência a conhecer a perspectiva e o sofrimento de uma mulher, de modo a facilitar a conscientização do impacto de suas ações nas mulheres, na relação conjugal e na vida familiar. A personagem principal - Roz - identifica e nomeia uma série de anestesias relacionais do ponto de vista da mulher vítima. Roz reflete também sobre elementos da dinâmica conjugal, mostrando ações e reações dela e de seu parceiro. O livro pode, portanto, ser um instrumento de estudo interessante para incentivar homens a pensarem a respeito do tema, identificarem suas próprias anestesias relacionais e seu papel na dinâmica conjugal (Guimarães, 2009).

Nesse contexto, decidimos utilizar o livro em alguns atendimentos individuais e grupais com homens autores de violência doméstica no acompanhamento psicossocial do Serviço de Assessoramento aos Juízos Criminais - SERAV. O doutorando atua como psicólogo no SERAV da Subsecretaria Especializada em Violência e Família - SUAF da Secretaria Psicossocial Judiciária SEPSI do Tribunal de Justiça do Distrito Federal e dos Territórios - TJDFT. A história dos personagens teve boa aceitação entre esses homens. O contexto de grupo favoreceu a reflexão sobre algumas semelhanças e diferenças com a vivência narrada no livro e proporcionou aos participantes saírem do estado de minimização e negação da violência. Esse processo reforçou a ideia de utilizar o livro em uma pesquisa com homens, de modo a permitir a nomeação de anestesias e o reconhecimento de outros elementos presentes na dinâmica conjugal marcada pela presença de violências. Apresentamos, a seguir, algumas justificativas e embasamentos teóricos para pesquisas com homens autores de violência, inclusive os estudos na área da Psicologia. 


\section{Pesquisas com homens autores de violência}

A extrema escassez de estudos e pesquisas internacionais e nacionais com homens em situação de violência conjugal é apontada por diversos/as pesquisadores/as (Blay, 2014; Lima \& Büchele, 2011; Oliveira \& Gomes, 2011; Randle \& Graham, 2011; Separavich \& Canesqui, 2013). Propostas de pesquisa sobre gênero, masculinidades, conjugalidades e violência são, portanto, relevantes devido à lacuna existente na literatura internacional e nacional. Urge a ampliação de estudos nessa área (Aguiar, 2009; Ávila, Machado, Suxberger \& Távora, 2014).

É fundamental o aprimoramento do conhecimento referente a homens autores de violência contra a mulher e a sua integração nas ações e nos estudos sobre o enfrentamento à violência. Essa inclusão dos homens é defendida por diversos estudos da área (Aguiar, 2009; Aguiar \& Diniz, 2008; Alves, Pinto, Silveira, Oliveira \& Melo, 2012; Araújo, 2012; Beiras \& Cantera, 2012; Blay, 2014; Figueira, 2011; Guimarães, 2014; Maciel \& Barbosa, 2010; Medrado, 2010; Medrado, Lemos \& Brasilino, 2011; Ravazzola, 2015; Separavich \& Canesqui, 2013; Siqueira, 2012). Separavich e Canesqui reforçam essa ideia:

A inserção dos homens como sujeitos nos estudos sobre a violência, a partir do referencial de gênero e masculinidades, tem contribuído para a crítica ao modelo hegemônico de masculinidade, sendo ressaltado que, para que esta forma de violência seja erradicada socialmente, faz-se necessária a conscientização dos próprios homens, em particular, e da sociedade, de uma forma geral (Separavich \& Canesqui, 2013, p. 424).

A relação entre gênero, violência e masculinidades atrai interesse bem menor quando comparada aos estudos sobre gênero, mulheres e violência conjugal (Oliveira \& Gomes, 2011). O termo gênero ainda é quase que sinônimo exclusivo de estudos sobre mulheres e as diversas implicações da condição feminina (Medrado \& Méllo, 2008).

Existem poucos estudos sobre homens e violência conjugal. Grossi, Minella e Losso (2006) fizeram um levantamento e localizaram 286 publicações brasileiras sobre violência doméstica e familiar no período entre 1975 e 2005. Destas apenas 7\%, ou seja, o equivalente a 16 estudos abordaram os homens ou masculinidades como tema das pesquisas. Oliveira e Gomes (2011) também realizaram uma análise de estudos brasileiros sobre masculinidades e violência conjugal. Buscaram publicações em diversos meios com as seguintes expressões: "violência conjugal e homens", "violência de gênero e homens", "violência contra mulher e homens", e "masculinidade e violência". O levantamento encontrou e analisou qualitativamente 54 textos brasileiros sobre o tema até o ano de 2009.

Incluir os homens e ampliar os estudos na área de gênero, masculinidades e violência é relevante para clarear outras faces do problema da violência conjugal e para expandir o conhecimento e a compreensão desse fenômeno. Tais estudos poderão trazer nova luz à questão, 
além de identificar iniciativas que aprimorem as pesquisas e intervenções voltadas para homens e mulheres com vistas à superação da violência (Alves et al., 2012).

Esses estudos devem abarcar diversos elementos estratégicos, especialmente quanto aos aspectos de gênero e masculinidades. Medrado (2010) aponta que é preciso incluir análises relacionadas aos processos de socialização e sociabilidade masculinas. Beiras e Cantera (2012) também afirmam que as pesquisas devem abranger o conhecimento de aspectos identitários e subjetivos da construção das masculinidades. Esses autores e autora concordam que são os significados do ser homem em nossas sociedades que promovem e alimentam as bases simbólicas da violência baseada em gênero. É fundamental compreender tais significados de modo a promover novos posicionamentos, atitudes, relações e, assim, possibilitar a construção de recursos e estratégias de mudanças. Medrado e Méllo (2008) defendem que tais estudos devem levar em consideração a "interveniência dos aspectos da socialização e das identificações de gênero na produção e configuração dos sofrimentos e no envolvimento dos homens com episódios de violência" (p. 81).

Lima e Büchele (2011) afirmam que os obstáculos enfrentados no Brasil pelos programas de atenção aos homens convergem com as dificuldades apontadas em muitos estudos internacionais, especialmente quanto aos resultados modestos e às dificuldades de vinculação dos homens aos serviços de acompanhamento e atenção a eles. Cabe ressaltar, no entanto, que embora os efeitos sejam modestos, eles são positivos. Os índices de desistência são altos e variam entre 20 e 50\%, sejam nos casos em que os homens procuram os serviços por demanda voluntária ou por meio de encaminhamentos feitos através de medida judicial.

Constatamos que existem poucas pesquisas que avaliam a efetividade dos programas de atendimento aos homens autores de violência conjugal (Akoensi, Koehler, Lösel \& Humphreys, 2013; Feder \& Wilson, 2005; Gondolf, 2011). Akoensi et al. realizaram um estudo de revisão que mostrou que dentre 10.446 títulos pesquisados sobre intervenção com homens, apenas 12 trabalhos avaliaram os resultados de ações voltadas para essa população de maneira sistemática.

Alguns estudos importantes comprovam os resultados positivos desses programas (Matjasko et al., 2012; Scott, King, McGinn \& Hosseini, 2011). Matjasko et al. encontraram oito estudos de meta-análise e de revisão sistemática sobre programas de intervenção com homens jovens nos EUA. Seis desses estudos encontraram resultados significativos dessas intervenções - a não reincidência variou entre 36 a $70 \%$.

Scott et al. (2011) realizaram uma pesquisa no Canadá sobre os efeitos de um grupo motivacional para favorecer a adesão de homens autores de violência extremamente resistentes a intervenções. Os participantes foram divididos em 3 amostras. A primeira e a segunda amostra 
foram compostas por homens não resistentes e resistentes ao acompanhamento, respectivamente, que passaram apenas pela intervenção tradicional de 16 encontros. A terceira amostra foi de homens resistentes que passaram pela intervenção motivacional de seis encontros e depois mais 10 encontros do grupo tradicional. O grupo motivacional aumentou consideravelmente o índice de adesão $(84,2 \%)$ de homens resistentes quando comparado a outros homens que passaram somente pela intervenção tradicional, com taxas de adesão de 46,5\% para os homens resistentes e de $61,1 \%$ para os homens não resistentes.

É nosso entendimento que a pequena quantidade de estudos sobre a eficácia das intervenções com homens deve servir como elemento impulsionador de novas pesquisas. Os estudos existentes mostram dados que apontam para a possibilidade de mudança e de transformação de homens autores de violência conjugal. É importante aumentar a motivação e a adesão dos homens aos programas para que essa mudança realmente seja possível. É preciso encontrar estratégias de reflexão mais criativas e atrativas que favoreçam a escuta das dificuldades e necessidades dos homens, ou seja, é necessário ir além da mera punição, prisão ou responsabilização/ressocialização. É fundamental pensar relacionalmente de modo a não reificar ou estabelecer um determinismo das assimetrias baseadas em gênero (Medrado, 2010). Essas ideias vão de acordo com as de Medrado et al. (2011):

Para se enfrentar a violência doméstica e familiar contra a mulher faz-se necessário considerá-la efetivamente como uma violência de gênero, em sua dimensão relacional, com suas marcações políticas, históricas e culturais, e não uma violência de sexo, restrita exclusivamente ao corpo e/ou à experiência de mulheres ou dos considerados "agressores" (Medrado et al., 2011, p. 477).

Dessa forma, urge o investimento nos processos de sensibilização de gênero e ressignificação simbólica dos próprios profissionais que atuam com homens e mulheres em situação de violência conjugal. Os profissionais e a sociedade como um todo precisam refletir e conhecer melhor o fenômeno (Araújo, 2012; Guimarães, 2014; Medrado et al., 2011).

Randle e Graham (2011) revisaram a literatura sobre os efeitos da violência conjugal sobre os homens. Elas perceberam que existem expressivas lacunas nos estudos sobre violência e masculinidades. As autoras chamaram atenção para a necessidade de realização de mais pesquisas qualitativas sobre a experiência de homens em contexto de violência conjugal de modo a gerar conhecimentos sobre a questão.

Os/as diversos/as pesquisadores/as citados acima apontam para a necessidade de inserir os homens autores de violência nas pesquisas, políticas, programas e ações de intervenções em casos de violência conjugal. Esses estudos ressaltam a importância de começar a escutar esses homens de forma diferenciada. Para isso, é preciso investir no conhecimento das dimensões afetivas como um 
dos elementos que compõe a complexa trama do fenômeno da violência conjugal. A Psicologia tem um papel relevante nessa área e não pode se esquivar dessa demanda.

\section{Pesquisas da Psicologia sobre homens autores de violência}

A Lei Maria da Penha (Lei 11.340/2006) inspira, aprimora e estimula novas possibilidades de atendimento psicossocial, inclusive com os homens autores de violência conjugal. No entanto, o enfoque integral e multidisciplinar proposto na Lei exige pesquisas para inovar e avaliar essas intervenções (Ávila et al., 2014; Beiras, 2014; Machado, 2014). Medrado, Lemos e Brasilino (2011), baseados na perspectiva relacional de gênero (Gregori, 1993), afirmam que é preciso conhecer melhor as bases psicossociais sobre as quais se constroem as relações humanas. Acrescentam, assim, mais um elemento para a compreensão deste fenômeno, que demanda estudos para o entendimento dos diversos aspectos das dinâmicas subjetivas e relacionais da violência.

Incluir as dimensões subjetiva e relacional juntamente com os aspectos culturais e institucionais (Medrado, 2009) pode agregar dados relevantes na análise desse fenômeno complexo. Oliveira e Gomes (2011) afirmam que essa abordagem não pode deixar de incluir reflexões sobre as experiências vividas pelos homens autores de violência em diferentes contextos. É necessário também valorizar as falas masculinas sobre seus sofrimentos e necessidades e ter a compreensão de que dar atenção aos homens não corresponde necessariamente a promover a desresponsabilização sobre seus atos. Vários/as autores/as corroboram essa ideia e defendem a realização de mais pesquisas que explorem as dimensões afetivas, individuais e relacionais em casos de violência conjugal (Aguiar, 2009; Aguiar \& Diniz, 2008; Alvarenga, 2012; Araújo, 2012; Diniz, 2011; Fávero, 2010; Figueira, 2011; Guimarães, 2014; Manita, 2008; Macedo, 2013; Medeiros, 2010, 2015; Moore, 2015; Silva, 2012; Siqueira, 2012).

A complexidade da violência conjugal exige a aproximação do discurso de várias áreas do conhecimento, dentre elas a Sociologia, Perspectiva Feminista e Psicologia. Nesse contexto, a Psicologia, em especial a Psicologia Clínica, é convidada a dizer algo sobre esses processos (Angelim, 2009), sem incorrer no erro de atribuir e diagnosticar inadequadamente psicopatologias às pessoas envolvidas nesse fenômeno social (Guimarães, 2009; Soares, 2005).

A Psicologia Clínica precisa desenvolver ferramentas para compreender as dinâmicas presentes nas relações conjugais marcadas por ações violentas. É necessário ampliar o conhecimento sobre a violência conjugal do ponto de vista psicológico para contribuir para a promoção de mudanças de valores - pessoais, relacionais, institucionais e sociais - para fundamentar políticas públicas (Fávero, 2010). Aguiar (2009) reforça essa necessidade de mais estudos da Psicologia sobre masculinidades e violência conjugal para ampliar o entendimento teórico e subsidiar a construção de intervenções efetivas nesses casos: 
Os trabalhos desenvolvidos com homens autores de violências conjugais são muito recentes e ainda não são bem conhecidos. Estudos sobre os agressores, bem como estudos sobre as intervenções psicológicas realizadas com eles correspondem a uma das maiores lacunas entre as reflexões que ainda não foram desenvolvidas no processo de prevenção e atenção à violência doméstica (Aguiar, 2009, p. 8).

A complexidade da relação entre gênero, masculinidades, conjugalidades e violência nos estimula a aceitar nessa pesquisa o desafio de aventurar rumo a uma maior compreensão do fenômeno da violência a partir da realização de pesquisa com homens autores de violência conjugal. Entendemos que é impossível entender efetivamente a violência conjugal sem incluir os homens como pessoa central da dinâmica relacional marcada pela violência e das ações voltadas ao seu enfrentamento. A responsabilização e a punição, incluindo a prisão, podem e precisam ser aplicadas em vários casos, mas não devem ser as únicas respostas dadas aos homens em situação de violência conjugal.

A literatura pesquisada aponta para a necessidade urgente de pesquisas e de construção e avaliação de novas propostas interventivas que sejam mais adequadas aos casos de violência conjugal e que respeitem e enxerguem esses homens como seres humanos. Os homens, quer tenham comportamentos violentos ou não, estão inseridos em uma sociedade patriarcal que também é prejudicial a eles. Assim, concordamos plenamente com Acosta, Andrade e Bronz (2004) ao afirmarem que:

Ao trabalharmos com a temática da violência masculina, ao contrário de estarmos lidando com a miséria humana, como muitos acreditam, nossos trabalhos têm revelado a riqueza humana dos seus participantes, ampliando seus recursos internos e externos para resolução da violência de gênero (Acosta et al., 2004, p. 34).

Urge a mudança na forma de olhar para os homens ditos "agressores" de modo a não enxergá-los como verdadeiros monstros. Cabe aprimorar o conhecimento das bases psicossociais, ou seja, das dimensões psicológicas, afetivas, individuais e relacionais, e as demais especificidades da dinâmica conjugal marcada pela violência. Temos que valorizar as experiências vividas e as falas dos homens sobre seus sofrimentos e necessidades, além de buscar a responsabilização pelos seus atos.

Entendemos ser importante ajudar os homens a acreditarem em suas capacidades de resolverem dificuldades relacionais de outro modo que não seja necessariamente pelo uso da violência. É preciso oferecer ferramentas para ajudá-los na compreensão à respeito deles mesmos, sobre suas diferenças, individualidades, potencialidades, dificuldades, etc. É fundamental uma atenção diferenciada para que eles próprios iniciem o processo de autocuidado, de autoresponsabilização e de conscientização das anestesias, contradições e paradoxos presentes na dinâmica relacional e nas manifestações de violência conjugal. Essas mudanças só podem ocorrer, 
no entanto, se forem oferecidas ferramentas para que os homens possam entender o que os aprisiona e como eles lidam com a relação conjugal. Esse entendimento pode subsidiar intervenções com esse público.

Queremos contribuir para ampliar as reflexões sobre o tema da violência conjugal. Não temos a pretensão de ser exaustivos ou de esgotar o assunto, dada a sua complexidade. Esperamos que essa tese de doutorado constitua uma contribuição para esse campo de estudos a partir do olhar da Psicologia Clínica.

A tese foi intitulada "'Ela não precisava chamar a polícia...’: anestesias relacionais e duplo-vínculos na perspectiva de homens autores de violência conjugal”. A citação "Ela não precisava chamar a polícia” do título da tese foi escolhida por ser a resposta de um dos homens da pesquisa e a fala que outros participantes escolheram como a mais importante em suas vivências conforme a Tabela 6.9A do capítulo dos resultados. Essa citação também foi escolhida por entendermos que ilustra bem o impacto da construção da masculinidade hegemônica, que tende a fomentar a ideia de posse do homem sobre a mulher, o que para muitos é entendido como uma atribuição de direito ao uso da força como forma de imposição de seus desejos e de dominação sobre seu corpo, sexualidade, vontades.

Essa ideia de posse favorece a instalação de anestesias que dificultam a percepção da violência e facilitam o processo de naturalização das agressões no espaço privado. Contribui, assim, para que homens considerem desnecessária a busca da Justiça ou de terceiros por parte da mulher. Muitos homens percebem a denúncia das mulheres como algo desnecessário por considerarem que não houve violência. Geralmente, eles não conseguem reconhecer a violência sofrida pelas ex/companheiras e não compreendem a denúncia como um meio para elas buscarem e receberem apoio e proteção. O processo de socialização tem grande peso na naturalização da violência por parte dos homens. Essa banalização exerce forte estímulo e legitima o uso da força física como forma de restaurar o poder e como estratégia de resolução dos conflitos (Maciel \& Barbosa, 2010; Silveira et al., 2009).

$\mathrm{O}$ intuito dessa pesquisa foi entender algumas dimensões da violência, mais especificamente, refletir sobre os duplo-vínculos e as anestesias relacionais presentes na dinâmica conjugal na perspectiva dos homens autores de violência conjugal. A teoria do duplo-vínculo e o conceito de anestesias relacionais serão definidos e discutidos no Capítulo 2 dessa tese. Oferecemos um instrumento simples, intenso e de grande impacto emocional para ajudar os próprios homens a perceberem alguns aspectos que lhes aprisionam a essa relação. Acreditamos que esse pode ser um passo inicial e valioso para diversos homens em um processo longo de libertações, mudanças e transformações para superação da violência conjugal. 


\section{Objetivos da Pesquisa}

A complexidade do tema da violência conjugal impõe o desafio de ampliar a compreensão dos fatores que levam homens autores de violência a cometerem a violência, negarem, minimizarem o impacto de seus atos e permanecerem na relação. Essa proposta de trabalho visa entender como o conhecimento da história de um casal inserido em contexto de violência - por meio do livro "Mas ele diz que me ama" - pode influenciar a percepção de vivência de violência conjugal de homens.

Acreditamos na importância de ajudar e instrumentalizar esses homens a refletirem sobre o impacto das agressões em suas vidas, na vida de suas parceiras e de outros membros da família. Nesse contexto, torna-se fundamental ajudá-los a identificar as anestesias relacionais que favorecem a manutenção da violência conjugal, assim como o modo que eles nomeiam e percebem alguns aspectos de seu relacionamento. O propósito principal é contribuir para a compreensão da dinâmica conjugal marcada pela presença de violência a partir do ponto de vista dos homens. Outra intenção é colaborar para aprimorar e consolidar estratégias de pesquisa e de intervenção voltadas aos homens, às mulheres e casais envolvidos em conjugalidades marcadas pela violência com base em uma perspectiva da Psicologia Clínica.

A revisão de literatura revelou a tendência de homens autores a naturalizarem a violência em suas relações e a perceberem as agressões de outros homens como sendo mais graves que aquelas cometidas por eles próprios no contexto de sua relação (Aguiar, 2009; Chaves \& Silva, 2010; Dohmen, 2006; Figueira, 2011; Ghesti-Galvão, Machado \& Costa, 2010; Moreira \& Matta, 2006; Oliveira \& Gomes, 2011; Rangel \& Tusi, 2010). Essa naturalização da violência dificulta a percepção das agressões pelas pessoas envolvidas na dinâmica conjugal, inclusive pelos homens autores (Lila, Gracia \& Herrero, 2012; Nascimento, Gomes \& Rebello, 2009; Silveira et al., 2009; Toneli, Beiras, Clímaco, \& Lago, 2010).

Pesquisas também mostraram que homens autores de violência conjugal tendem a escutar com mais facilidade outras mulheres vítimas do que a suas próprias parceiras (Chaves \& Silva, 2010; Ghesti-Galvão, Machado \& Costa, 2010; Moreira \& Matta, 2006; Papp, 2002; Ramos, 2013; Santos, 2015). Essas pesquisas revelam que esse contato com o sofrimento de outras mulheres abre possibilidades para ouvi-las com empatia e para repensar o seu próprio padrão interacional, pois permite que esses homens escutem com menor resistência uma pessoa do sexo feminino - muitas vezes em situação equivalente à da ex ou atual parceira. Os resultados dessas pesquisas foram o ponto de partida para a problematização e o delineamento da questão de pesquisa que serve de base para essa tese (Seidl de Moura \& Ferreira, 2005):

- Como homens autores de violência conjugal encaminhados para intervenção grupal junto ao sistema de Justiça expressam a negação, a minimização e a 
desresponsabilização da violência em suas vivências quando em contato com a história dos personagens do livro "Mas ele diz que me ama" (Penfold, 2005/2006)?

A partir de abordagem sistêmica feminista e de gênero, essa pesquisa de doutorado teve como objetivo geral identificar como homens autores de violência conjugal que participaram de pesquisa como parte de uma intervenção psicossocial na Justiça manifestam indícios de anestesias relacionais e de dimensões duplo-vinculares presentes na dinâmica conjugal marcada pela presença de violência, por meio da leitura e reflexão em grupo do livro: "Mas ele diz que me ama" (Penfold, 2005/2006). Tivemos o intuito principal de facilitar a compreensão de anestesias relacionais e de características de duplo-vínculos por serem processos presentes em muitas dinâmicas de violência conjugal. Os objetivos específicos da pesquisa são:

- Identificar os sentimentos despertados nos homens pela leitura do livro;

- Compreender os elementos que os homens percebem como semelhantes ou diferentes ao compararem suas histórias pessoais com as dos personagens do livro;

- Identificar as anestesias relacionais apresentadas pelos homens autores;

- Conhecer como os homens nomeiam e percebem a sua própria história, utilizando o título do livro como elemento estimulador para identificação de características duplovinculares que estruturam relações conjugais permeadas pela violência.

A tese está organizada em seis capítulos para tentar alcançar esses objetivos (Seidl de Moura \& Ferreira, 2005). A relação entre gênero, masculinidades e violência conjugal é discutida no primeiro capítulo como forma de abordar as vulnerabilidades sociais vivenciadas por homens, de modo especial por aqueles que subscrevem rigidamente ao modelo de masculinidade hegemônica. Apresentamos, no segundo capítulo, duas teorias sistêmicas - anestesias relacionais e duplo-vínculo que podem nos auxiliar na compreensão da violência conjugal, especialmente, no modo como os homens também podem ficar aprisionados à dinâmica relacional. No terceiro capítulo, discutimos as características dos programas de atenção aos homens no cenário internacional e no Brasil, que podem buscar efetivamente a identificação e revisão dos processos de naturalização da violência conjugal e ampliar os meios para o efetivo enfrentamento desse fenômeno.

No quarto capítulo apresentamos a estratégia metodológica. Realizamos pesquisa qualitativa que utilizou o livro "Mas ele diz que me ama" (Penfold, 2005/2006) como um estímulo indutor de reflexões para homens autores de violência. No quinto capítulo, descrevemos os principais resultados do estudo. A apresentação dos dados teve como foco discutir alguns processos de anestesias relacionais e de duplo-vínculo da dinâmica conjugal na perspectiva de homens autores de violência. Por fim, apresentamos as considerações finais no último capítulo. 
Acreditamos que o procedimento adotado nessa pesquisa possa ajudar homens autores a vislumbrarem o seu papel e sua posição em sua própria dinâmica conjugal. Esperamos, ao contemplar os objetivos da pesquisa, ajudá-los a manifestar alguns dos processos de anestesia e de duplo-vínculo que justificam o seu comportamento frente às parceiras e os aprisionam à relação conjugal marcada pela violência. Essa pesquisa é pioneira, pois não encontramos estudos sobre masculinidades, anestesias relacionais e dimensões de duplo-vínculos em relacionamentos marcados pela violência conjugal sob a perspectiva de homens autores. 


\title{
Capítulo 1
}

\section{Gênero, masculinidades e naturalização da violência conjugal}

\author{
Olha lá! \\ Ele não é feliz \\ Sempre diz \\ Que é do tipo cara valente \\ Mas veja só \\ A gente sabe \\ Esse humor \\ É coisa de um rapaz \\ Que sem ter proteção \\ Foi se esconder atrás \\ Da cara de vilão \\ Então, não faz assim, rapaz. \\ Não bota esse cartaz \\ A gente não cai não \\ (Música: Cara Valente - Maria Rita)
}

A violência de gênero é um problema complexo, grave e crescente em todo o mundo e que deve ser visto como uma questão social e de saúde pública. Essa maior visibilidade dada às manifestações de violência deve incluir as suas várias formas, dentre elas, a violência contra a mulher e a violência conjugal (Beiras et al., 2012; Diniz, 2011, 2013; Fávero, 2010; Lima \& Büchele, 2011; Medrado \& Méllo, 2008).

Adentramos, nesse primeiro capítulo, na intrínseca relação entre gênero, masculinidades e violência conjugal para discutir o processo de naturalização da violência pelos homens autores. Começamos com uma breve análise acerca da evolução histórica do conceito de masculinidades. Apontamos a relevância de incluir os homens nos estudos sobre violência e gênero. Em seguida, buscamos apontar como a socialização de gênero contribui para a tendência masculina de recorrer às violências como forma de impor autoridade e controle. Discutimos a relação entre conjugalidade e violência.

O fenômeno da naturalização da violência requer um olhar para dimensões que vão muito além do indivíduo. Essas dimensões são fundamentais para compreendermos os processos de construção sociocultural da naturalização e da banalização da violência pelos homens autores. Por último, apresentamos algumas formas de repensar as masculinidades rumo a relações mais igualitárias e, nesse contexto, colocamos o importante questionamento sobre a posição dos homens na violência conjugal: eles devem continuar sendo vistos apenas como oponentes agressores ou podem também ser agentes de mudança? 


\section{Masculinidades: evolução histórica do conceito}

Na década de 1990 houve significativa expansão dos estudos de gênero. Foi nesse contexto que tais estudos passaram a contemplar as masculinidades. Esse processo ocorreu especialmente nas Ciências Sociais e Humanas. Os principais autores/pesquisadores que tiveram destaque na temática das masculinidades foram Miguel Valle de Almeida (1996), Michael Kimmel (1994/1997), Robert Connell (1995, 1997), Pierre Bourdieu (1998/1999); Daniel Welzer-Lang (2001). Esses autores são referências internacionais dos estudos das masculinidades. No Brasil, Sócrates Nolasco (1993, 2001) teve um papel relevante e foi um dos pioneiros na área (Aguiar, 2009; Beiras \& Cantera, 2012; Figueira, 2011; Teixeira, 2009).

Apesar dos principais autores terem despontado nos últimos 20 anos, Teixeira (2009) assinala que diversas pesquisadoras clássicas realizaram estudos fundamentais para a área, mesmo que não tratassem diretamente das masculinidades em seus trabalhos. Dentre elas, destacam-se Margareth Mead (1988), Simone de Beauvoir (1946/2000) e Joan Scott (1995). As pesquisas iniciais sobre masculinidades e esses estudos clássicos do movimento feminista foram importantes para começar a cogitar a ideia de incluir os homens nos estudos de gênero.

Margareth Mead realizou um grande estudo na década de 1930 em três tribos na Nova Guiné. Ela foi uma das primeiras pesquisadoras a aprofundar as reflexões de que os comportamentos de homens e mulheres não são inatos e nem tampouco puramente biológicos. Ela defendeu que os comportamentos são construídos de maneira diferenciada por cada grupo social (Teixeira, 2009).

Não há como discutir gênero sem falar em Simone de Beauvoir. Ela foi uma das pessoas mais influentes do século passado. Beauvoir (1946/2000) afirmou que "não se nasce mulher, tornase mulher" em seu clássico e importante livro "O segundo sexo". Ela buscou desnaturalizar a condição feminina e questionou a essencialização das relações entre o sexo biológico e a construção da categoria social "mulher". Beauvoir evidenciou a influência de fatores sociais na formação das masculinidades e feminilidades, ou seja, na construção das identidades. Ela mostrou como as questões de gênero afetam a construção da subjetividade de cada pessoa e as relações entre homens e mulheres. Os estudos de Beauvoir não incluíram o processo de construção das masculinidades, mas foram importantes para fundamentar as discussões sobre a dessencialização do ser mulher, e, consequentemente, do ser homem (Beauvoir, 1946/2000; Diniz, 1999; Teixeira, 2009).

Beauvoir (1946/2000) intrigou e incomodou a sociedade e a academia ao colocar a questão: “Como a metade da humanidade é uma minoria social?". No mundo há praticamente a mesma quantidade de mulheres e homens. No entanto, a população masculina detém quase a totalidade dos bens e posses, impõe as leis e normas sociais e ocupa quase todos os lugares de poder. As reflexões 
de Beauvoir contribuíram para revelar que as mulheres não são minoria numérica, elas são uma minoria social, marcada historicamente pela desigualdade, opressão e violência.

Algumas pesquisas recentes confirmam essa desigualdade. Segundo a Organização das Nações Unidas - ONU (2010), a população mundial chegou a quase 7 bilhões de pessoas em 2010, com aproximadamente 57 milhões de homens a mais do que mulheres em todo o mundo. No Brasil, a Pesquisa Nacional por Amostra de Domicílio de 2013 revelou que viviam 103,5 milhões de mulheres, equivalente a 51,4\% da população (IBGE, 2013).

O relatório da Organização das Nações Unidas - mais especificamente da ONU Mulheres, intitulado "Progresso das Mulheres no Mundo 2015-2016: Transformar as economias para realizar os direitos", mostra que os direitos econômicos e sociais das mulheres são limitados pelo fato de ainda vivermos em uma sociedade extremamente machista. Os salários das mulheres são $24 \%$ inferiores aos dos homens no exercício da mesma função (ONU Mulheres, 2015). Esses dados reforçam as constatações realizadas por Beauvoir (1946/2000) há mais de 50 anos. As suas reflexões sobre as desigualdades entre homens e mulheres continuam extremamente atuais.

Joan Scott (1995) trouxe relevante contribuição em sua obra "Gênero: uma categoria útil de análise histórica". Esse trabalho foi fundamental para a contextualização do caráter histórico da diferença sexual entre homens e mulheres e para o entendimento das relações sociais entre os sexos. Para Scott, qualquer informação sobre as mulheres é necessariamente informação sobre os homens. Estudar um, implica o estudo do outro (Scott, 1995; Teixeira, 2009; Diniz, 2013). Uma das definições mais importantes sobre gênero foi realizada por Scott (1995), por meio de duas proposições relacionadas:

- "Gênero é um elemento constitutivo de relações sociais baseadas nas diferenças percebidas entre os sexos"; e

- "Gênero é uma forma primária de dar significado às relações de poder" (p. 85).

Scott (1995) revelou um novo entendimento de gênero, que deve ser uma forma central de análise das relações humanas, ou seja, não pode ser desconsiderado, nem sequer ser visto como uma posição periférica. Por meio de sua análise histórica, Scott mostrou que as questões de gênero estão extremamente arraigadas na sociedade em todas as instâncias. A sua propagação inicia-se por meio de símbolos culturais, que influenciam a forma como a sociedade compreende o significado de ser homem e de ser mulher, das masculinidades e feminilidades. Os conceitos normativos aparecem como meio de interpretação dos significados desses símbolos, especialmente por meio de leis e de normas sociais e familiares. Esses conceitos são a base para a atuação das instituições e organizações sociais. Por último, essa interação entre símbolos e normas que pautam a vida 
institucional e social alcança a identidade subjetiva das pessoas. Gênero vai muito além das relações conjugais e familiares, abarca toda a estrutura simbólica, subjetiva, relacional, social e cultural.

Gênero é um conceito sociológico relativamente contemporâneo. Ele surgiu para contrapor o foco sobre o sexo biológico e a ideia da existência de "uma suposta natureza" feminina e masculina. Esse conceito trouxe a concepção de que papéis e expectativas acerca de comportamentos femininos e masculinos são o resultado de uma construção social que varia de acordo com a cultura e o momento histórico de cada sociedade (Alves \& Diniz, 2005; Banco Mundial/CEPIA, 2003; Saffioti, 1999; Scott, 1995).

Nesse contexto, cabe diferenciar sexo e gênero. O termo "sexo" foi atribuído à diferenciação biológica entre machos e fêmeas. Gênero se refere à construção social, cultural e histórica da masculinidade e da feminilidade em um determinado tempo e espaço. Os padrões de comportamento feminino e masculino são definidos um em relação ao outro. Gênero implica necessariamente em uma relação, em uma sociabilidade. As relações sociais de gênero permitem a transformação dos indivíduos em homem ou mulher e formam essas duas categorias de identidade. Gênero é a construção social do masculino e do feminino (Alves \& Diniz, 2005; Debert \& Gregori, 2008; Ramos, 2003; Saffioti, 1999; Scott, 1995; Silveira et al., 2009).

As ideias de Scott são importantes para compreendermos que não existe nem homem nem mulher enquanto categorias universais. As pessoas aprendem a desempenhar os papéis masculinos e femininos de acordo com regras, crenças e tradições em função do contexto cultural de cada sociedade. Há uma construção social diversa em cada cultura, marcada pelo momento histórico, tempo e espaço em que as pessoas vivem. A socialização masculina e feminina é dinâmica, se movimenta e se modifica em cada contexto e época (Scott, 1995; Teixeira, 2009).

As relações entre os sexos não são estáticas nem eternas. Gênero tem que ser compreendido como um conceito que perpassa símbolos, normas, regras, ideias, valores instituições, estruturas, práticas cotidianas, rituais, ou seja, por vários aspectos que constituem as relações sociais (Scott, 1995; Teixeira, 2009). Dessa forma, consideramos que os estudos das masculinidades e das feminilidades têm apenas uma divisão didática. É importante estudar a relação entre homens e homens, mulheres e mulheres, homens e mulheres.

Esses estudos clássicos do movimento feminista sobre gênero foram importantes para a inclusão das masculinidades nas pesquisas de gênero. Vários autores começaram a investir na ampliação do conhecimento na área no âmbito internacional e nacional. Houve uma intensificação desses estudos especialmente a partir da década de 1990. Realizamos, a seguir, um breve resumo das ideias dos autores que são referências nos estudos das masculinidades. 
Dentre os autores que se dedicaram ao estudo das masculinidades, merece destaque o trabalho de Robert Connell (1995, 1997). Ele é um dos autores mais citados na área, especialmente por trazer o conceito de masculinidade hegemônica. Connell corrobora as ideias de Scott (1995) ao defender que a construção das masculinidades ocorre através da relação com as referências femininas e com as outras masculinidades (Teixeira, 2009). A masculinidade é definida por esse autor como sendo a posição nas relações de gênero entre homens e as mulheres, que envolve as práticas pelas quais as pessoas se comprometem com essa posição e os efeitos dessas práticas na experiência corporal, na personalidade e na cultura (Connell, 1995; Separavich \& Canesqui, 2013).

Connell afirma que existem diferentes masculinidades e uma hierarquia entre elas. Ele chama atenção para a importância de incluir vários aspectos sociais para discutir essa hierarquização, tais como raça e etnia, classe, geração e orientação sexual (Connell, 1995, 1997, Teixeira, 2009). Em resumo, os quatro padrões de masculinidades definidos por Connell são:

- Masculinidade Hegemônica: dominação do masculino sobre o feminino;

- Masculinidade Subordinada: dominação entre homens, por exemplo, heterossexual sobre homossexual;

- Masculinidade Cúmplice: identifica-se com a hegemônica e tira vantagem dessa relação;

- Masculinidade Marginalizada: marcada pela dominação etno-racial e econômica.

A masculinidade hegemônica não se refere a indivíduos, mas a um padrão de masculinidade que em dado momento histórico é visto por um determinado grupo como referência a ser seguida. Ela não é um modelo fixo, mas uma posição que resulta de um jogo de poder e que está sempre em disputa e processo de transformação. Tem, portanto, dimensão relacional, histórica, móvel, fluída e possui fissuras. Qualquer parâmetro de masculinidade possui aspectos ideológicos e naturaliza as diferenças entre os sexos ao encobrir os aspectos das construções sociais das hierarquias de gênero (Connell, 1997; Separavich \& Canesqui, 2013; Silveira et al., 2009).

Miguel Valle de Almeida, pesquisador português, avançou nas discussões trazidas por Connell sobre a categoria da masculinidade hegemônica. Almeida realizou estudo em uma aldeia ao sul de Portugal e classificou essa categoria como um modelo cultural ideal, uma caricatura. A masculinidade hegemônica não retrata nenhum homem diretamente. O modelo de masculinidade visto como hegemônico exerce poder entre os próprios homens e entre homens e mulheres (Almeida, 1995; Teixeira, 2009).

Almeida afirma que existem formas hegemônicas e subordinadas de ser homem e de ser mulher. A masculinidade hegemônica define a inferioridade do feminino e das masculinidades subalternas no contexto do patriarcado. Essa masculinidade dita uma prática de dominação, especialmente sobre as feminilidades e as masculinidades subordinadas, como é o caso dos homens 
homossexuais, e/ou negros, e/ou pobres. Ele demarcou a importância da "dessencialização" do masculino (Almeida, 1995; Separavich \& Canesqui, 2013; Teixeira, 2009).

Vale ressaltar, que patriarcado pode ser entendido como um padrão hegemônico legitimado pela sociedade, que define as relações de gênero e as condutas historicamente desiguais. O sistema patriarcal no contexto brasileiro "construiu o masculino valorado a partir da ação e da virilidade, e o feminino valorizado dentro das funções de esposa e mãe” (Silveira et al., 2009, p. 959).

Pierre Bourdieu realizou reflexão sobre esse contexto de supremacia masculina, especialmente em seu livro clássico “A dominação masculina”. Para ele, a dominação do masculino sobre o feminino ocorre na corporeidade de homens e de mulheres. Ele entende os corpos como construção social (Bourdieu, 1998/1999; Teixeira, 2009).

Bourdieu afirma que existe um custo alto para aderir aos papéis masculinos. Há uma tentativa de tentar encobrir a insegurança, a autoestima baixa e a fragilidade. Ao mesmo tempo, os homens têm que demonstrar poder, virilidade e força. Essa situação gera uma constante tensão e sofrimento. O fato é que os homens também são vítimas da própria dominação masculina. Essa vitimização dificilmente é percebida pela sociedade e pelos próprios homens (Bourdieu, 1998/1999; Zuma et al., 2013).

Michael Kimmel (1994/1997) considerou a masculinidade como um conjunto de significados que mudam constantemente, que são construídos na relação dos homens com eles mesmos, com os outros e com o mundo. Esse conceito não é estático, nem temporal, mas histórico. Ele também contribuiu para a evolução do conceito de masculinidade hegemônica, não como uma questão corporal, mas constituída no antagonismo entre masculino e feminino.

Kimmel defende que há um modelo imposto socialmente para homens seguirem e negarem. A população masculina deve negar e evitar quaisquer características ditas femininas (Aguiar, 2009; Kimmel, 1994/1997; Separavich \& Canesqui, 2013). Esse modelo a seguir e a fugir é resumido abaixo:

um homem há que ser agressivo, competente, forte, racional, ter uma sexualidade sem limites, em oposição à ternura, fragilidade, afetividade, à sexualidade contida das mulheres, revelando, assim, o caráter homofóbico de sua constituição genérica (Separavich \& Canesqui, 2013, p. 418).

Esse molde exige dos homens constante reiteração, confirmação, ratificação e avaliação de sua masculinidade perante seus iguais, devendo ser legitimada por eles. Os grupos de pares podem atuar como fiscais das masculinidades (Beiras \& Cantera, 2012; Kimmel, 1994/1997; Medrado \& Méllo, 2008; Medrado, 2009).

Daniel Welzer-Lang (2001) discute as definições de heterossexismo e de homofobia e suas ligações com a dominação masculina para romper com definições naturalistas/essencialistas dos 
homens. Ele também amplia o debate sobre o modelo hegemônico e discute um modelo homofóbico da masculinidade. Ele entende que a superioridade masculina sobre as mulheres é essencializada na cultura (Separavich \& Canesqui, 2013; Welzer-Lang, 2001).

Nolasco, pesquisador brasileiro, também destacou a maneira opressiva na qual os homens são socializados. A formação da identidade dos homens sofre influência dessa socialização e segue o modelo hegemônico. Geralmente começa na família e perpassa todos os segmentos sociais. Dessa forma, Nolasco entende a masculinidade contemporânea como frágil, sofrida e o "bode expiatório" da violência atual (Aguiar, 2009; Nolasco, 1993, 2001; Oliveira \& Gomes, 2011).

$\mathrm{O}$ avanço conceitual nos últimos 30 anos à respeito da construção das masculinidades foi fundamental para ampliar a compreensão sobre gênero. Esse avanço permitiu verificar que a categoria gênero não diz respeito apenas às mulheres e masculinidades não se referem somente aos homens. Gênero vai além da relação entre homens e mulheres (Teixeira, 2009). Nesse período, não só foi possível incluir os homens nos estudos sobre gênero, mas percebemos ser imprescindível a sua inclusão.

Masculinidades e feminilidades podem ser construídas entre homens e mulheres, mulheres e mulheres, homens e homens. Dessa forma, uma perspectiva mais relacional de gênero também contribui para não essencializar o masculino (Teixeira, 2009).

Existe uma pluralidade de masculinidades. Na sociedade brasileira, por exemplo, o modelo hegemônico masculino pode ser caracterizado como: branco, heterossexual, provedor da família, másculo, racional, controlador da sexualidade feminina, viril. Mesmo com essa referência, é impossível existir apenas um modelo de masculinidade. A crise da masculinidade surge quando muitos homens não se identificam, não seguem esse modelo e percebem a necessidade de novas alternativas e possibilidades (Machin et al., 2011; Separavich \& Canesqui, 2013; Teixeira, 2009).

A masculinidade hegemônica e a socialização de gênero atuam como um mapa, um molde a ser seguido. Embora nem todos os homens desempenhem o padrão, ele serve como referência social para a população masculina e pode ser extremamente nocivo para as mulheres e para os próprios homens. Esse padrão tem consequências para toda sociedade, incluindo as relações inter e intragêneros. Esse modelo de masculinidade hegemônica atua como um dos desencadeadores de violência social, de gênero e de vulnerabilidade de homens (Moore, 2015; Separavich \& Canesqui, 2013; Teixeira, 2009).

As discussões sobre masculinidades iniciadas pelas autoras feministas clássicas e aprofundadas pela intensificação de seus estudos específicos a partir da década de 1990 foram importantes para evolução desse conceito. Esse avanço conceitual é revolucionário, paradigmático e pode lançar novos olhares sobre as experiências dos homens e as masculinidades. Tal avanço tem o 
potencial de incluir efetivamente os homens nas políticas públicas como sujeitos de direitos e de necessidades, inclusive quando eles estão inseridos como autores no contexto de violência conjugal. Não só é possível, mas é preciso incluir os homens nos estudos sobre gênero e violência. A partir dessa discussão inicial sobre as diversas masculinidades, apresentamos uma base conceitual para refletir sobre as alarmantes vulnerabilidades da população masculina às violências.

\section{Socialização de gênero e vulnerabilidades masculinas para violências}

Os estudos do campo da saúde pública, de gênero e o movimento feminista expuseram as feridas emocionais e físicas de uma masculinidade patriarcal. O modelo de socialização masculina é nocivo não só para as mulheres, mas para os próprios homens. Ambos são vítimas desse contexto social (Machin et al., 2011; Separavich \& Canesqui, 2013). Os feminismos revelaram, inicialmente, as inúmeras e gravíssimas feridas do modelo patriarcal para as mulheres. Começamos, recentemente, o processo de enxergar os prejuízos e as diversas consequências deletérias desse modelo para os homens.

Uma das grandes vantagens dos estudos da área de saúde pública foi a revelação de muitas fragilidades e vulnerabilidades do dito sexo "forte" (Lima, Büchele \& Clímaco, 2008; Norman, 2011; Separavich \& Canesqui, 2013; Silveira et al., 2009). Os dados são tão alarmantes que em 2008 foi lançada a Política Nacional de Atenção Integral à Saúde do Homem - PNAISH em nosso país (Brasil/MS, 2008).

A PNAISH já constitui um marco para a discussão da saúde masculina no Brasil, especialmente por reconhecer os agravos à saúde dos homens como verdadeiros problemas de Saúde Pública. Essa política considera também os determinantes sociais que afetam os homens, ou seja, desde fatores causadores de doenças e de outras diversas vulnerabilidades (Camargo, Campos, Torres, Stuhler \& Matão, 2011; Lopes \& Leite, 2013; Separavich \& Canesqui, 2013; Siqueira, 2012).

O maior reconhecimento da PNAISH pode contribuir para um novo olhar e entendimento dos homens como sujeitos do cuidado de saúde e portadores de necessidades que demandam abordagens específicas (Alves et al., 2012). Essa Política pode garantir mais visibilidade a muitas vulnerabilidades e fragilidades masculinas e incentivar a instalação e ampliação das ações e pesquisas com homens.

Entendemos o conceito de vulnerabilidade conforme a concepção de Nascimento, Gomes e Rebello (2009). Para eles, vulnerabilidade vai além do sujeito ao englobar o contexto da pessoa e por considerar as estruturas sociais vulnerabilizantes. Esse conceito inclui os obstáculos e os riscos para o sujeito, bem como as suas resistências e estratégias criativas para o enfrentamento dessas vivências. Para Camargo et al. (2011), a vulnerabilidade é constituída por aspectos individuais, 
sociais e pragmáticos. Esses aspectos envolvem valores pessoais, condições cognitivas e comportamentais, recursos preventivos, acesso à saúde, amparo social, acesso a informação, desenvolvimento social, comprometimento, gestão e monitoramento de programas.

Vulnerabilidade é um conceito amplo, multifacetado e depende do contexto pessoal, social, cultural e econômico. Para Camargo et al. (2011), a vulnerabilidade masculina no contexto brasileiro tem várias particularidades:

A vulnerabilidade masculina se caracteriza pela inconsistência entre a perspectiva de saúde como prevenção, atualmente incentivada pela Política Nacional de Atenção Integral à Saúde do Homem, e a perspectiva de saúde pautada na medicalização (curativa) e nas características funcionais (poder econômico e acesso ao trabalho). Somando-se a isso, o cuidado é atribuído pelo homem à família, em especial às mães, que são fonte de informação sobre cuidados e "cuidadoras por essência". Aos homens, em especial aos adolescentes e adultos jovens, resta seguir as expectativas de um contexto cultural e social muitas vezes perverso: o jovem como plenitude de força, virilidade e invulnerabilidade, que percebe o cuidar de si mesmo ou do outro como um atributo que não lhe cabe ou não lhe identifica (Camargo et al., 2011, p. 190).

A socialização de homens estimula a repressão de suas emoções e tem um impacto direto sobre a saúde, a morbimortalidade e as diversas formas de manifestação de violência dos homens e de toda sociedade. A agressividade é um dos poucos sentimentos estimulados e aceitos socialmente para os homens expressarem (Randle \& Graham, 2011). Esse padrão de socialização também contribui para a adoção de condutas destrutivas e autodestrutivas pelos homens e expressa fragilidades e vulnerabilidades masculinas (Camargo et al., 2011; Fávero, 2010; Medrado \& Méllo, 2008; Moore, 2015; Nascimento et al., 2009).

As mortes de homens por causas externas são cinco vezes superiores às femininas no Brasil. O maior pico acontece no grupo etário masculino de 20 a 24 anos, com proporção de 10:1 (Brasil, 2008; Separavich \& Canesqui, 2013). Os levantamentos realizados pela Anistia Internacional - AI (AI, 2014) e o Mapa da Violência 2014 (Waiselfisz, 2014) revelam a gravidade dos homicídios de jovens no Brasil.

O Mapa da Violência (Waiselfisz, 2014) mostra que as taxas de assassinatos aumentaram 148,5\% nos últimos 30 anos: 1,2 milhões de pessoas foram mortas entre 1980 e 2012; 556 mil na última década; e 56 mil em 2012, o que representa 154 vítimas, em média, por dia. A maioria das vítimas de homicídios em 2012 foi composta por homens jovens (30 mil) e negros (77\% dos assassinatos nessa faixa etária). A violência letal foi a principal causa de morte para a população masculina com idade entre 15 e 29 anos de idade. Os homicídios representaram mais da metade das mortes para essa parte da população brasileira no período entre 2000 e 2005 (IBGE, 2009).

Em 2014, a Anistia Internacional lançou a Campanha Jovem Negro Vivo no Brasil como uma das tentativas para reduzir esse quadro. Baseada nos dados do Mapa da Violência, a AI afirma 
que o Brasil é o país que mais mata pessoas no mundo. Há mais de uma década, o Brasil está com índices que ultrapassam 50 mil homicídios por ano. Em dados absolutos, houve mais homicídios em nosso país do que nas doze maiores zonas de guerra do mundo - incluindo países como Iraque, Sudão, Afeganistão e Colômbia. Um total de 192 mil pessoas foram mortas no Brasil no período entre 2004 a 2007 (AI, 2014; Waiselfisz, 2014).

Esses dados são mais alarmantes quando conciliamos os aspectos de masculinidades, de raça e condição social. Nos últimos anos, houve queda do número de homicídios da população branca e aumento do número de vítimas na população negra. Homens negros morrem duas vezes mais do que os homens brancos por causas externas. A proporção sobe para três vezes mais quando consideramos a faixa etária dos 20 aos 24 anos (Waiselfisz, 2014).

Em 2015 foi lançado o relatório "Índice de Vulnerabilidade Juvenil à Violência e Desigualdade Racial 2014” pelo Fórum Brasileiro de Segurança Pública - FBSP, em parceria com a Secretaria Nacional de Juventude da Presidência da República e a Organização das Nações Unidas para a Educação, a Ciência e a Cultura - UNESCO, que corrobora e atualiza os dados apresentados acima. O risco de um jovem negro ser assassinado é, em média, 2,5 vezes mais alto que de uma pessoa branca em nosso país. Os jovens negros, com idade entre 12 a 29 anos, configuram como as principais vítimas e estão em situação de maior vulnerabilidade à violência em quase todos os estados do Brasil (UNESCO/Brasil, 2015). Essa violência é seletiva. Infelizmente, ela “é tolerável em determinadas condições, de acordo com quem a pratica, contra quem, de que forma e em que lugar" (Waiselfisz, 2015, p. 9).

O mesmo acontece com jovens em condições socioeconômicas precárias. Os homens em situação de pobreza e jovens na faixa etária entre 15 e 29 anos são as principais vítimas e agentes dos homicídios no Brasil (IBGE, 2009). O "Mapa da Violência 2015” confirma esses dados: 59\% das vítimas de assassinatos por arma de fogo são jovens abaixo de 30 anos de idade. Dos 24.882 mortos por essa causa em 2012, a grande maioria era jovem, homem, negro e pobre. A taxa e a quantidade absoluta de jovens vítimas de homicídios por armas de fogo foram os mais altos desde 1980, quando iniciaram a série de estudos do Mapa da Violência (Waiselfisz, 2015).

Os dados apresentados e discutidos acima deixam evidente que os homens também são impactados negativamente pelo sistema patriarcal e pela socialização de gênero (Beiras et al., 2012). Para Moore (2015), as masculinidades devem ser classificadas como vulneráveis em nossa sociedade. Ele afirma que ainda há um pensamento vigente de que para classificação da população masculina como vulnerável, é preciso associá-la a outras categorias: tais como pessoa com deficiência, idoso, negro, criança ou adolescente. É difícil enxergar os homens como vulneráveis. Essa invisibilidade das diversas vulnerabilidades dos homens produz um afastamento de um lugar 
de necessidades e de cuidados. Um dos maiores desafios que enfrentamos nesse sentido diz respeito à superação das vulnerabilidades masculinas relacionadas à violência.

\section{Vulnerabilidade masculina para a violência conjugal}

A forte relação entre socialização masculina e violência foi descortinada por pesquisas recentes na área da saúde e pelo movimento feminista (Aguiar, 2009; Beiras \& Cantera, 2012; Camargo et al., 2011; Fávero, 2010; Maciel \& Barbosa, 2010; Nascimento et al., 2009; Randle \& Graham, 2011; Separavich \& Canesqui, 2013). A violência configura como uma das maiores vulnerabilidade dos homens. Essa vulnerabilidade é alta seja para o papel de vítima e/ou de autor de várias formas de agressões (Alves et al., 2012).

A naturalização e a banalização da violência são construídas socioculturalmente. A estreita relação entre homens/violência tem como um dos principais fatores propulsores a socialização dos homens baseada no modelo hegemônico de masculinidade. A violência faz parte da constituição das masculinidades tradicionais. Esse modelo tradicional naturaliza a violência como um atributo dos homens e como um instrumento de afirmação do "ser homem". Os homens podem compreender como natural a necessidade de serem provedores, agressivos e competitivos (Alves et al., 2012; Beiras \& Cantera, 2012; Nascimento et al., 2009).

A violência é justificada, aceita, permitida e necessária entre homens em muitos contextos. Os mais fortes geralmente são os mais temidos e respeitados. Essa valorização da violência aumenta a expectativa de comportamentos que demonstrem força, virilidade, valentia. Tais comportamentos desenvolvem-se em ambientes que induzem a agressividade, a adoção de práticas de risco à vida e condutas autoritárias, todas geradoras de relações humanas violentamente conflituosas (Beiras \& Cantera, 2012; Fávero, 2010; Separavich \& Canesqui, 2013).

A violência é socialmente aceita como marca ou prova de masculinidade. Essa necessidade de prová-la é intensamente reiterada e atualizada, especialmente por outros homens e em público. A sua confirmação ou desconfirmação ocorre desde a infância, na amizade entre meninos ou por outros homens de referência - pais, tios, vizinhos etc. (Beiras \& Cantera, 2012; Fávero, 2010; Lima et al., 2008; Nascimento et al., 2009).

A violência é estimulada tanto pelos aspectos que potencializam quanto os que ferem a "masculinidade dos homens". Os valores relacionados à masculinidade hegemônica potencializam essa sensação, tais como o consumo de álcool e uso de armas. Esses aspectos simbolizam dominação, dão sensação de coragem, de invulnerabilidade e de aumento da força. Homens são estimulados a expressarem a masculinidade através de atos violentos. A partir desses valores reforçados socialmente, a força e poder são confundidos como atributos exclusivamente "naturais" e biológicos masculinos. Isso ajuda a entender os altos índices de mortes masculinas por causas 
externas: acidentes de carro, violência e suicídio (Alves et al., 2012; Camargo et al., 2011; Separavich \& Canesqui, 2013).

As questões que ferem ou ameaçam a masculinidade também motivam o uso da violência como forma de reafirmá-la ou recuperá-la (Alves et al., 2012). Geralmente, os homens têm que provar ou garantir sua masculinidade nas seguintes situações:

1) Infidelidade feminina: de fato, fantasiosa ou quando há apenas suspeita. Nesses casos a violência é uma forma de punir a companheira e de demarcar a propriedade dela na frente de outros homens e da sociedade;

2) Diante do processo atual de empoderamento das mulheres na sociedade. Há um sofrimento e insegurança de muitos homens, que podem sentir-se confusos e ameaçados com as mudanças sociais. Nesse contexto, eles podem perceber a violência como um meio de tentar resgatar a dominação;

3) Momentos em que sentem a impossibilidade de exercer o papel de provedor, especialmente em situações de desemprego ou de baixo salários (Alves et al., 2012).

A vulnerabilidade de homens para o envolvimento com condições violentas aumenta significativamente em situações nas quais eles percebem um obstáculo ao cumprimento das imposições e expectativas sociais da masculinidade, ou seja, onde fica evidente a dificuldade ou impossibilidade de corresponder às expectativas e papéis de gênero tradicionais. É nessas situações que muitos homens podem adotar soluções drásticas, inclusive o homicídio e o suicídio (Alves et al., 2012; Fávero, 2010; Teixeira, 2009)

As normas culturais tradicionais repassadas de forma complementares para meninos e meninas influenciam a construção das identidades e as futuras relações conjugais, familiares e sociais. Desde muito cedo, os meninos são encorajados a rejeitarem as expressões de determinados tipos de vulnerabilidade e de dependência. Do mesmo modo, as meninas costumam ser treinadas com base em uma pedagogia do medo e ficam com pouca assertividade diante de várias situações da vida, entre elas as de violência e outras situações constrangedoras (Fávero, 2010).

A socialização de gênero marcada pelo patriarcado difunde estereótipos rígidos que podem repercutir negativamente nos relacionamentos no espaço doméstico. Os homens são treinados para ser autoridade máxima do lar, independentes, livres, individualistas, objetivos, racionais, juízes. Aprendem que ser chefe de família implica em legislar sobre tudo do espaço privado e sobre todos os membros da família, que significa criar e fazer cumprir as regras do microssistema doméstico. De forma complementar, as mulheres são socializadas desde muito pequenas para serem dependentes, submissas, emotivas, encarregadas de responsabilidades domésticas e da criação dos/as filhos/as (Maciel \& Barbosa, 2010). 
A adesão, muitas vezes rígida, a esses papéis de gênero, especialmente os que envolvem risco e violência, tem um significado de obrigação e vergonha, não de liberdade. Muitos homens e mulheres sentem-se totalmente incapazes de romper com as expectativas sociais, mesmo quando estão conscientes das consequências negativas para si e para quem ele e ela amam. Dessa forma, há um aprisionamento dos homens e das mulheres na condição de vítimas e autores de violência (Aguiar, 2009; Alves et al., 2012; Fávero, 2010; Lima et al., 2008).

Essa socialização de homens é tão severa que pode configurar verdadeiros traumas em torno da construção da identidade e das vivências dos papéis de gênero (Fávero, 2010). Os homens são socializados desde tenra idade para reprimir suas emoções e isso tem um impacto direto sobre a saúde e a violência (Medrado \& Méllo, 2008). A família e a sociedade passam diversas mensagens de que ser homem significa resolver sozinho os seus problemas: "se apanhar na rua, apanha duas vezes"; “custe o que custar você deve resolver isso por conta própria” (Maciel \& Barbosa, 2010). Adultos desautorizam, assim, a expressão de sentimentos como amor, ternura, dor, medo e fidelidade ao mesmo tempo em que estimulam a externalização da agressividade, do controle, da superioridade (Randle \& Graham, 2011; Separavich \& Canesqui, 2013).

Compreender a relação entre violência e os processos de socialização de homens é importante para ampliar o entendimento desse fenômeno. A violência é socialmente construída, e geralmente tem como base o modelo hegemônico de masculinidade. Devemos tomar o cuidado, no entanto, de não generalizar e rotular todos os homens como violentos e achar com isso que eles não podem mudar. Não podemos categorizar os homens como eternos agressores e as mulheres como vítimas em uma lógica binária, simplista e essencializadora que o próprio movimento feminista se propôs a combater.

Beiras e Cantera (2012) defendem uma maior atenção à construção das diversas subjetividades masculinas e suas relações com a violência. Para eles, os conceitos de masculinidades, subjetividades e violência vão de encontro a aspectos históricos, sociais e culturais. Os valores culturais e históricos ajudam a entender como a exigência social de assumir riscos e de constantemente provar a masculinidade contribuem para que a autoestima de muitos homens seja baseada na performance (Fávero, 2010). Pontes (2009) afirma que os estudos de gênero podem ser úteis para ajudar no entendimento de ambivalências vivenciadas por vários homens e mulheres em situação de violência conjugal. A construção social da subjetividade das pessoas pode ser entendida como resultado de uma dimensão simbólica e estrutural.

Muitos homens estão expostos a diversos tipos de vulnerabilidades. Precisamos entender melhor os processos de socialização masculina e como eles favorecem a inserção e a manutenção de homens em relacionamentos conjugais marcados pela violência conjugal. É especialmente 
importante entendermos os processos que levam à naturalização da violência. Nesse sentido, discutimos a seguir a necessidade de ampliar a visão sobre os diferentes estilos de conjugalidade marcados pela violência e como os homens são vistos nessas dinâmicas.

\section{Violência, masculinidades e os diferentes estilos de conjugalidade}

A violência de gênero é um problema social, de saúde pública e de violação de direitos humanos, sexuais e reprodutivos. Apesar de sua alta prevalência e relevância, essa violência passou a ser tratada como questão de saúde pública muito recentemente em nossa história, ou seja, apenas a partir da década de 1980 no Brasil (Angelim \& Diniz, 2010; Fávero, 2010; Macedo, 2013; Matjasko et al., 2012; Randle \& Graham, 2011; Silveira et al., 2009; Toneli et al., 2010).

A violência de homens contra mulheres ocorre desde tempos imemoriais. Inúmeros registros, relatos, pinturas ou textos sobre o assunto demonstram a sua antiguidade (Medrado \& Méllo, 2008). A violência é um fenômeno biopsicossocial grave ainda vigente e não superado na sociedade. Não há fronteiras para esse problema, uma vez que está presente em todos os países, entre todas as raças, etnias, níveis socioeconômicos e pessoas de todas as idades estão sujeitas a ele (Lima \& Büchele, 2011; Ponce-Antezana, 2012).

A violência, por ser um fenômeno complexo, recebeu diversas nomenclaturas: violência contra a mulher; violência doméstica e familiar; violência de gênero; violência conjugal etc. Esses conceitos têm várias características em comum, mas cada um tem sua especificidade, vantagens, desvantagens, limitações e até paradoxos em seu uso (Alves et al., 2012; Debert \& Gregori, 2008; Lima \& Büchele, 2011; Manita, 2008; Randle \& Graham, 2011; Silveira et al., 2009; Soares, 2012; Toneli et al., 2010) Nesse contexto, vamos discutir brevemente cada um desses conceitos para clarear e justificar a nossa escolha pelo uso de "violência conjugal".

A violência é definida por Alves et al. (2012) como sendo a "dominação própria de relações humanas marcadas pela ausência do diálogo e pela instrumentalização do sujeito” (p. 975). A violência tem natureza instrumental e é baseada em relações desiguais. Essa concepção está de acordo com a da Organização Mundial de Saúde - OMS, que define violência como:

o uso intencional da força física ou do poder, real ou em ameaça, contra si próprio, contra outra pessoa, ou contra um grupo ou uma comunidade, que resulte ou tenha grande possibilidade de resultar em lesão, morte, dano psicológico, deficiência de desenvolvimento ou privação (Krug et al., 2002, p. 5).

A violência pode ser entendida, então, como algo que extrapola os limites da pessoa e tem o potencial de invadir e desestruturar a subjetividade. Constitui uma ação que trata um ser humano não como sujeito, mas como uma coisa ou objeto (Toneli et al., 2010).

A "violência de gênero" é uma das formas de violência. Ela é caracterizada pela opressão e crueldade nas relações entre homens e mulheres, homens e homens e mulheres e mulheres. Essa 
violência ocorre em relações marcadas pela desigualdade e assimetria entre os sexos. As mulheres, independente da idade, configuram como as maiores vítimas desse fenômeno social, geralmente perpetrado por homens conhecidos, integrantes de sua rede familiar ou de amizade. As manifestações de violência constituem, portanto, uma das mais intensas expressões de dominação e de controle do homem sobre a mulher (Braga, Nascimento \& Diniz, 2006; Cunha, 2008; Minayo, 2013; Zuma, Mendes, Cavalcanti \& Gomes, 2013).

A Lei 11.340/2006, intitulada Lei Maria da Penha, utiliza o termo "violência doméstica e familiar contra a mulher" e a define em seu artigo $5^{\circ}$ como: "qualquer ação ou omissão baseada no gênero que lhe cause morte, lesão, sofrimento físico, sexual ou psicológico e dano moral ou patrimonial” (Brasil, 2006). Essa definição foi baseada na Convenção de Belém do Pará (OEA, 1994), que compreende a violência contra a mulher em seu artigo $1^{\circ}$ como: "qualquer ato ou conduta baseada no gênero, que cause morte, dano ou sofrimento físico, sexual ou psicológico à mulher, tanto na esfera pública quanto na privada".

A "violência conjugal" é uma das modalidades da violência de gênero e da violência doméstica e familiar contra a mulher. É “exercida por um dos cônjuges/companheiro(a) ou excônjuge/ex-companheiro(a) sobre o(a) outro(a)" (Manita, 2008, p. 31). A violência conjugal é vivenciada por uma pessoa que tem lugar de referência para o/a indivíduo/a que comete a agressão.

É a violência que acontece entre cônjuges em uma relação de intimidade e na dinâmica relacional do casal. É um processo que envolve e mistura diversos sentimentos contraditórios, inclusive de amor e ódio. Os laços de afeto unem o casal, muitas vezes sob a premissa do amor romântico. Inclui qualquer relacionamento afetivo que se conserve ou mesmo que tenha sido desfeito (Cunha, 2008; Medrado, 2009; Toneli et al., 2010).

A violência conjugal manifesta-se em vários níveis, de acordo com a sua natureza. Essa natureza pode ser física, psicológica, sexual, patrimonial e moral, conforme definida pela Lei Maria da Penha (Brasil, 2006; Diniz, 2011; CFEMEA, 2009; Krug et al., 2002; Minayo, 2013). Apesar dessa diferenciação didática e teórica, os diversos tipos de violência não ocorrem isoladamente, geralmente acontecem várias formas de violência em uma mesma relação conjugal. As agressões emocionais estão sempre presentes quando há violência, independente do tipo de agressão (Saffioti, 1999).

O termo violência conjugal perpassa vários outros conceitos e tipos de violência. Inclui algumas dimensões da violência de gênero, por ser influenciada pela desigualdade entre homens e mulheres imposta pela cultura patriarcal. Representa a violência familiar ao envolver parceiros/as em uma relação íntima de afeto; constitui uma forma de violência doméstica, por geralmente ocorrer em ambiente privado; é nomeada como violência contra a mulher, pelo fato de a mulher ser 
a principal vítima (Guimarães, 2009; Soares, 2012). Alguns pesquisadores, especialmente dos Estados Unidos, estão substituindo atualmente o uso do termo "violência conjugal" pelo termo "violência perpetrada por parceiro íntimo" (Krug et al., 2002; OMS, 2005; Randle \& Graham, 2011).

Adotamos nesse trabalho o termo "violência conjugal", por entender que ele coloca ênfase na relação entre os/as parceiros/as; na interação entre conjugalidade e violência; e por considerar que a dinâmica do casal vai muito além da agressão. Dessa forma, focamos no estudo da violência de homens contra mulheres no contexto das relações conjugais. Não temos o objetivo de analisar a violência mútua ou de mulheres contra homens nesse estudo.

Esse termo - violência conjugal - deve ser usado com o cuidado para não culpar a pessoa vítima pela agressão sofrida, mas compreendendo a contribuição de cada cônjuge na manutenção do relacionamento. Busca-se, além disso, não perder o foco sobre as desigualdades de gênero presentes na relação. O termo é mantido também com base na compreensão que a conjugalidade está inserida em uma dimensão social e cultural mais ampla. A violência conjugal geralmente envolve agressões repetitivas e com uma escalada crescente em frequência e intensidade. É uma das expressões da violência contra mulher contextualizada nas relações conjugais (Cunha, 2008; Debert \& Gregori, 2008; Narvaz \& Koller, 2006). Nesse sentido, concordamos com Ponce-Antezana (2012), que afirma que a violência que homens desenvolvem contra as mulheres "não é um fenômeno isolado que ocorre no interior da mente 'errada' do indivíduo, mas sim uma questão social inserida numa subjetividade individual" (p. 15). Utilizamos nesse estudo, então, o termo "violência conjugal” com o enfoque na "violência conjugal contra a mulher" para abarcar melhor a complexidade da temática, mas estamos cientes de que esse termo também possui limitações e exige os cuidados discutidos acima.

Outra delimitação importante dessa pesquisa foi a contextualização de homens autores de violência conjugal em relações heterossexuais, por entendermos que a violência conjugal em casais homoafetivos tem várias especificidades e exige outras leituras que não poderiam ser contempladas satisfatoriamente nesse trabalho. Cabe apontar ainda que reconhecemos a necessidade de que sejam realizados mais estudos sobre relações conjugais homoafetivas (Cantera, 2007; Manita, 2008; Randle \& Graham, 2011).

Ponce-Antezana (2012) propõe uma reformulação conceitual da violência conjugal. Ele discorda da visão da violência como algo exógeno ao sistema social, pautada na compreensão da dinâmica entre os cônjuges como anormal ou da relação como anômala. Ponce-Antezana defende um novo olhar sobre a violência, que deve ser entendida como um fenômeno social complexo, resultado de um conjunto de práticas econômicas, sociais, políticas, jurídicas e culturais. A 
violência inclui uma série de violências simbólicas e estruturais, sendo vista como uma extensão de um sistema mais amplo e de uma ordem social patriarcal.

Esse autor chama atenção para a práxis contraditória e ambígua da violência conjugal. Ela é reprovada em determinados contextos e sentidos, mas legitimada e considerada válida em outras situações. Essa condição paradoxal da violência é tão evidente que se torna invisível. Mesmo com essa possível e deletéria invisibilidade, a violência nunca pode ser compreendida como alheia ao sistema social (Ponce-Antezana, 2012).

Ponce-Antezana (2012) propõe uma reformulação na forma de compreender os/as próprios/as indivíduos/as envolvidos/as na violência conjugal, em especial, os homens autores de violência. Ele afirma que ainda não se considera a individualidade e subjetividade dessas pessoas. Todos/as são considerados/as iguais, o que implica em intervenções gerais, de "tamanho único" para todos os casos. Ao tratar um sujeito universal, perde-se a conexão com a vida e as condições específicas dos destinatários da intervenção, que pode ficar cega para as dinâmicas envolvidas no sistema sexo/gênero (Diniz, 2011; Macedo; 2013; Ponce-Antezana, 2012).

A violência de gênero no casal é caracterizada por padrões e hábitos repetitivos, que podem atingir a condição de norma ou ordem na relação. No entanto, não significa que esses padrões sejam inamovíveis ou que todos os casos sejam iguais (Ponce-Antezana, 2012). Manita (2008) defende a ressignificação da ideia de imutabilidade da relação e do comportamento dos homens. Essa pesquisadora afirma que a violência conjugal é caracterizada por diversos comportamentos aprendidos no meio familiar e social. Dessa forma, esses comportamentos também podem ser "desaprendidos".

A violência é, portanto, fenômeno complexo e multidimensional, que exige leitura e modelos de intervenção também complexos e multidimensionais. Para a compreensão e a intervenção serem adequadas deve-se abranger as dinâmicas individuais, relacionais e socioculturais que sustentam essas formas de interações conjugais (Manita, 2008).

A violência contra as mulheres, especialmente a violência conjugal, foi o principal elemento propulsor dos feminismos no Brasil. Na França, por exemplo, o enfoque catalisador foi o assédio sexual (Bandeira, 2009; Teixeira, 2009). Bandeira afirma que várias ações e estratégias de resistência foram realizadas pelo movimento feminista nos últimos trinta anos no Brasil para tentar erradicar a diversas formas existentes de violência contra a mulher. A autora acredita, no entanto, para realmente ocorrer a redução ou eliminação da violência é preciso conhecer a fundo as características desse fenômeno. Entendemos que a construção desse conhecimento não será completa se não abarcar as masculinidades nos estudos da violência conjugal. 
$\mathrm{Na}$ análise de estudos brasileiros sobre homens e violência conjugal realizado por Oliveira e Gomes (2011), verificou-se duas diferentes inteligibilidades da problemática. Esses/as pesquisadores/as perceberam uma polêmica em torno de dois polos de entendimento do fenômeno como:

1) "Violência contra a mulher" ou "violência de gênero": geralmente ancorado no feminismo, por meio de uma abordagem sociocultural.

2) "Violência conjugal": também ancorado no feminismo, mas recebendo críticas desse movimento, e também de fora do feminismo.

As principais críticas ao primeiro polo referem-se à cristalização dos homens como agressores e das mulheres como vítimas da violência. Os maiores questionamentos sobre o segundo polo foram sobre a tendência de ter apenas explicações psicologizadas e relacionais, sem considerar as desigualdades de gênero na conjugalidade. Essas críticas foram importantes para que, atualmente, esses estudos consigam incluir as dimensões sociais nas análises relacionais da violência conjugal (Oliveira \& Gomes, 2011).

Teixeira (2009) corrobora que há essa polarização no Brasil, geralmente embasada em duas abordagens teóricas. A primeira abordagem tem como autora principal a grande feminista Heleieth Saffioti - socióloga e pesquisadora, que ganhou destaque em seu livro "Violência de gênero no Brasil atual" (1994). A violência é entendida como uma via de mão única, em que o homem é tido como o responsável e a mulher como a vítima da violência diante da desigualdade de gênero na sociedade.

A segunda abordagem teórica tem Maria Filomena Gregori - antropóloga e professora, como pesquisadora protagonista. O seu livro "Cenas e queixas: um estudo sobre mulheres, relações violentas e práticas feministas" (1993) foi um dos pioneiros e teve grande destaque na área. Ela defende o universo relacional da violência, em que as mulheres figuram como colaboradoras nas relações marcadas pela violência, como sujeitos e coparticipantes ativos na relação conjugal.

Gregori contrapõe a ideia naturalizante e essencialista do homem sempre como agressor e mulher sempre como vítima. Ela desmistifica a vitimização feminina, desconstruindo a concepção de passividade das mulheres presente em outras abordagens. Gregori faz uma crítica ao próprio movimento feminista por não considerar as resistências das mulheres nas relações conjugais e a possibilidade das mesmas relações virem a ser modificadas ou transformadas, seja com a separação ou mudança na relação (Debert \& Gregori, 2008; Gregori, 1993; Oliveira \& Gomes, 2011; Teixeira, 2009).

Outra abordagem surge na tentativa de percorrer uma terceira via, que assume uma visão dialógica e integrativa entre as duas abordagens anteriores. Essa abordagem entende a polarização 
acima como insuficiente e inexata. A terceira via promove um maior diálogo entre várias feministas e seus opositores (Oliveira \& Gomes, 2011).

Essa terceira via ainda é incipiente no Brasil e inclui os estudos de Grossi $(1998,2008)$ e Soares (1999). Soares percebe as vantagens e valida os dois polos, especialmente por ambos terem construído uma abordagem sociocultural do problema. A "terceira via" compreende os diferentes estilos de conjugalidade marcada pela violência. Essa abordagem inclui a violência conjugal clássica, caracterizada pelo terrorismo do homem contra a mulher e abrange também as violências mútuas, quando as relações conjugais são reciprocamente violentas. Entendemos que elas podem ser reciprocamente violentas, mas ressaltamos que a força e o potencial de causar dano às mulheres geralmente é maior (Medeiros, 2015; Oliveira \& Gomes, 2011; Teixeira, 2009).

Grossi (2008) é contra a essencialização das masculinidades como violenta e trouxe contribuições por discutir a influência do "amor romântico" na violência conjugal. Outros autores (Jablonski, 1991, 2003; McGoldrick, 2003; Papp, 2002) também problematizaram sobre a influência do amor romântico como uma construção social que afeta diretamente as relações conjugais, contribuindo para a instalação, a manutenção e escalada da violência, inclusive do feminicídio (Graham-Kevan, 2007; Medeiros, 2015; Oliveira \& Gomes, 2011; Teixeira, 2009).

As três formas de enxergar a violência conjugal foram e ainda são usadas como categorias teóricas e analíticas de compreensão do fenômeno no Brasil (Silveira et al., 2009). Todas têm relevâncias e limitações. A grande maioria dos estudos sobre masculinidade e violência conjugal no Brasil entende a problemática como questão relacional de gênero e adota a segunda ou terceira abordagem. Esses estudos abrangem a existência de diversos estilos de conjugalidade marcada pela violência (Oliveira \& Gomes, 2011; Silveira et al., 2009). Essas perspectivas da violência de gênero como relacional têm, atualmente, como principais autoras brasileiras: Maria Filomena Gregori, Miriam Pilar Grossi e Bárbara Musumeci Soares (Teixeira, 2009).

Cada conjugalidade é única - não podemos generalizar - ademais, existem relações que perpassam pelos três modelos. Nós concordamos com a visão da terceira via, sem deixar de considerar os outros modelos. Entendemos que essa via contempla melhor a complexidade do fenômeno, pois abrange inúmeras possibilidades de dinâmicas relacionais permeadas pela violência conjugal. Entendemos os homens e as mulheres inseridos no contexto dessa violência como seres complexos, sem reduzi-los às categorias estáticas e imutáveis de agressor e vítima. Ao escolher essa via, estamos cientes da necessidade de cuidar para não deixar de analisar as desigualdades de gênero na relação e as influências do contexto histórico e social sobre as relações familiares e conjugais. 
Soares (2012) argumenta a favor dessa visão. Ela afirma que a categorização simplista de homens e mulheres como autores e vítimas e que o engessamento dos diferentes estilos de conjugalidades contribuem para tornar esses/as homens e mulheres em pessoas refratárias à mudanças de autopercepção, de percepção do/a outro/a e, portanto, de comportamento. É fundamental, portanto, compreender melhor como os homens são vistos no contexto de violência conjugal.

\section{Homens na violência conjugal: de oponentes a agentes de mudança}

Houve consideráveis avanços na compreensão da violência de gênero e da violência conjugal. Essa evolução foi alavancada pela exposição cotidiana na mídia de casos de violência e após a promulgação de leis específicas em diferentes países, inclusive no Brasil com a criação da Lei Maria da Penha. Apesar desse progresso, a imagem do homem não mudou muito. Homens continuam sendo compreendidos apenas como agressores, algozes, perigosos, monstros. Vários questionamentos podem e devem ser feitos a respeito dos posicionamentos e comportamentos de homens em contextos de violência conjugal (Beiras et al., 2012):

Os homens são realmente sempre "apenas" agressores?

Quem são estes sujeitos?

Como se dá a inscrição relacional e social de homens como autores de violência?

Colocá-los na prisão é a melhor solução?

Que alternativas lhes são apresentadas?

Não existe resposta única para qualquer uma das perguntas formuladas acima. Cada uma delas revela a complexidade das dinâmicas conjugais marcadas pela violência. Afinal, existe a masculinidade hegemônica e outras masculinidades possíveis - e os homens transitam entre elas. Nesse contexto é preciso articular uma maior discussão sobre as masculinidades, gênero e violência de modo a promover reflexões, pesquisas e ações que resultem em um efetivo combate às várias formas de manifestação da violência de gênero (Toneli et al., 2010).

Escolhemos começar pelo termo "agressor", que é utilizado para definir os homens autores de violência. Consideramos importante sair da classificação simplista e reducionista dos homens como "agressores" e oponentes a serem combatidos para também inseri-los como potenciais agentes de mudança e de transformação da relação conjugal e da sociedade.

Moore (2015) verificou que a representação social da palavra "homem" carrega consigo grande carga negativa. As pessoas tendem a agregá-la a elementos como egoísta, violento, força física e poder. Se o termo "homem" já carrega estereótipos negativos, essa associação é potencializada quando é agregada à palavra "agressor" ou "violento". 
Vários termos foram criados recentemente para definir de forma mais complexa os comportamentos dos homens em situação de violência conjugal. Uma definição mais atual assume uma postura política e epistemológica ampla em uma tentativa de não reduzi-los à categoria de “agressores” (Toneli, Beiras, Clímaco \& Lago, 2010).

Alguns dos termos criados/adaptados foram:

- Homens que exercem/exerceram violência na conjugabilidade - HEVC (Beiras \& Cantera, 2012; Toneli, Lago, Beiras \& Clímaco, 2008; Veloso \& Natividade, 2013);

- Homens que cometem violência contra mulheres (Medrado \& Méllo, 2008);

- Homens autores de violência contra as mulheres (Silveira et al., 2009; Toneli et al., 2010; Veloso \& Natividade, 2013);

- Homens autores de violência doméstica (Lopes \& Leite, 2013);

- Homens denunciados por violência conjugal (Silveira et al., 2009)

- Homens autores de violência - HAV (Lima \& Büchele, 2011);

- Homens que praticam violência de gênero no casal (Ponce-Antezana, 2012);

- Homens que exercem violência contra ex/cônjuges (Ponce-Antezana, 2012).

Os termos acima diferem em pequenas especificidades para priorizarem alguns aspectos que os estudos consideram mais relevantes. Todos esses termos são semelhantes no intuito de não reduzir os homens a agressores. É inegável que foi construída uma associação entre os termos homens, agressores e violência. Essa discussão é relevante - de uma lado essa associação precisa ser levada em conta, de outro é preciso atuar para quebrar os preconceitos subjacentes.

Esse preconceito estende-se, infelizmente, aos profissionais, inclusive os que trabalham na área. Medrado et al. (2011) verificaram em uma pesquisa com profissionais que atuam no campo da violência conjugal que ainda predominam as formas reducionistas de pensar e a dicotomia homem/autor versus mulher/vítima, apesar da tentativa de vários/as pesquisadores/as para desconstruir essa visão. As mulheres foram e são geralmente referidas nos processos, artigos e pesquisas como "agredida", “a parte agredida", “abandonada”, “espancadas”, “ofendida", "pessoa vítima de violência", "protegida", "submissa", "vítima" etc. Os homens foram e são mencionados por profissionais por meio do uso de três categorias:

- Violência como traço ou marca identitária do homem que a comete: "agressor", "homem agressor", "agressor de mulheres", "agressor doméstico", “desumano", "opressor";

- Violência como uma prática: "autor do fato", "autores de violência contra a mulher", "homem autor de violência", "homem que cometeu violência";

- Marcações de poder ou de criminalidade: "chefão", "o que manda", “detentor do poder", "bandido", "criminoso". (Medrado et al., 2011, p. 474). 
O uso de termos como "agressor" tem um caráter cristalizador. Contribui para criar uma etiqueta essencialista, que rotula, define, reduz e transforma o homem naquilo que cometeu. Há uma redução do sujeito, uma fusão entre ser e fazer, que desloca o olhar do ato para o ator da violência sem considerar outras dimensões/características humanas da pessoa em questão (Medrado, 2009; Ponce-Antezana, 2012; Toneli et al., 2010).

Esse uso essencialista do termo pode criar uma identidade fixa para o "agressor". Não diferencia o "estar" do "ser" violento. Há uma caracterização do sujeito como agressor e de sua subjetividade como agressiva. A violência passa a ser uma essência de seu caráter. A sua personalidade pode ficar resumida à agressividade. Esse termo contribui, então, para um verdadeiro processo de desumanização do homem que em um dado contexto agiu como agressor. Isso ajuda a entender o fato de muitos profissionais tratarem esses homens não como humanos, mas como verdadeiros monstros. Contribui, também, para a recusa ou medo de muitos profissionais em atender essas pessoas (Beiras \& Cantera, 2012; Medrado, 2009; Medrado \& Méllo, 2008).

O uso do termo "agressor" figura, então, como um marcador identitário e tem efeitos importantes na forma de compreender os homens autores de violência. Afeta também a intervenção. Dificulta ou reduz drasticamente a possibilidade de transformação, de mudanças nas atitudes dos homens ou de construção de prevenção de novas violências. Aumenta o risco de generalização, de tratar todos os homens que cometem atos de violência como semelhantes, de agrupá-los de acordo com um protótipo único. É preciso, por isso, ter e promover um questionamento crítico sobre esse termo para desconstruir a essencialização da violência masculina (Beiras \& Cantera, 2012; Medrado, 2009; Medrado \& Méllo, 2008; Ponce-Antezana, 2012; Toneli et al., 2010).

Torna-se, portanto, necessário identificar e apontar esse potencial essencializador do uso do termo "agressor". As possibilidades de mudanças conceituais são importantes para a desconstrução e a superação da lógica binária e para ir além de atrelamentos dicotômicos entre bom-mau, homemmulher, agressor-ofendida. Os homens não são eternos agressores e as mulheres não são eternas vítimas.

Essa dicotomia é muito utilizada nos meios assistenciais e jurídicos. Muitos homens reclamam do tratamento da justiça por serem vistos apenas como criminosos. Precisamos superar essa visão simplista e reducionista de que a efetiva proteção das mulheres somente é possível com a punição dos homens (Alves et al., 2012; Beiras \& Cantera, 2012; Lima \& Büchele, 2011; Medrado, 2009; Medrado \& Méllo, 2008; Toneli et al., 2010; Walker, 1999). Nesse sentido, concordamos com Silveira et al. (2009), que afirmam que:

quando nos propomos a estudar os sentidos de violência contra as mulheres nas narrativas de homens denunciados por violência conjugal, nos deparamos com essa pluralidade. Uma leitura simplista sobre a questão é insuficiente e incoerente com a 
diversidade de situações, por isso aceitamos o desafio de realizar uma leitura que enfatiza as dinâmicas que revestem as relações socais (Silveira et al., 2009, p. 966).

A cristalização dos papéis de vítimas e de agressores não ajuda e ainda mais, pode atrapalhar a compreensão e a intervenção em situações de violência conjugal. A dicotomia vítima-algoz não leva à transformação. No entanto, perceber esse desafio não é suficiente para impedir o recurso a esse olhar reducionista. Muitos profissionais ainda têm dificuldade de enxergar os homens além de dominadores, exploradores e agressores (Beiras \& Cantera, 2012; Lima \& Büchele, 2011; Medrado, 2009; Medrado \& Méllo, 2008; Toneli et al., 2010).

Ao invés dessa procura por culpados ou oponentes, é fundamental o entendimento de aspectos da relação (Lima \& Büchele, 2011). Medrado et al. (2011) reafirmam a necessidade de ampliar as questões relacionais e de:

tomar esses relacionamentos sem criar uma dualidade algoz-vítima, pois isso implicaria a ideia de um agressor ativo e um agredido passivo. Essa dualidade desconsidera que os padrões distintos de comportamento instituídos para homens e mulheres são atualizados nas relações interpessoais, que implicam combinações e ambiguidades, ou seja, diversidades (Medrado et al., 2011, p. 477).

É preciso considerar e questionar várias dimensões sociais. Por exemplo, a marca sabidamente tradicional do próprio Direito e, consequentemente, do sistema de justiça. Os feminismos - e de modo especial - as autoras feministas no campo do direito - colocaram em pauta o próprio olhar e atuação do direito e do sistema de justiça (Magalhães, 2011; Pandjiarjian, 2002; Porto \& Costa, 2010). Dessa forma, pode-se e deve-se pensar em ampliar as estratégias para potencializar a compreensão e promover mudanças subjetivas e sociais:

1. Desses homens autores e de todos os homens, por meio de um processo amplo de reflexão e reconstrução das masculinidades e das feminilidades nas sociedades, ajudando assim, a reduzir ou interromper efetiva e preventivamente a violência (Ávila et al., 2014; Beiras \& Cantera, 2012; Silveira et al., 2009).

2. Das mulheres "vítimas" e de todas as mulheres, por meio de um processo amplo de reflexão e reconstrução das feminilidades nas diversas sociedades, para que mulheres parem de aceitar, minimizar, aguentar as violências por anos a fio, processo que causa danos à saúde física e mental de todas as pessoas inseridas na dinâmica (Diniz, 2011; Macedo, 2012; Medeiros, 2010)

3. Dos diversos sistemas sociais, dentre eles os sistemas familiares, educacionais, religiosos, de Justiça que tendem a reforçar e manter padrões e processos de engendramento marcados por posicionamentos tradicionais que tendem a causar danos a todos os envolvidos (Magalhães, 2011; Pandjiarjian, 2002). 
A intenção de problematizar essa discussão sobre os homens autores de violência não é negar ou minimizar a gravidade da violência conjugal. Nem tampouco ser contra a necessidade de punição, inclusive da prisão, que em muitos casos é imprescindível. No entanto, a leitura punitiva e puramente criminalista da violência é problemática. A sua resolução é muito difícil e não pode ser simplista. Exige novas diretrizes, pautadas na interdisciplinaridade, de modo a abranger aspectos além da punição, tais como a promoção, prevenção e reorientação dos homens, sejam eles os operadores do direito - juízes/promotores/advogados e/ou os autores da violência (Ávila et al., 2014; Beiras \& Cantera, 2012; Porto \& Costa, 2010; Silveira et al., 2009). Vale lembrar, inclusive, que esses homens "operadores do direito" e outros profissionais não estão isentos de serem também autores de violências contra suas mulheres.

Essa reflexão considera as diversidades dos indivíduos, das masculinidades e a variabilidade das conjugalidades e é importante para questionarmos, enquanto pesquisadores, profissionais que atuam nos serviços e sociedade, a postura política e epistemológica vigente na sociedade e para não cristalizarmos os homens como agressores. Beiras e Cantera (2012) argumentam que os termos "homem autor de violência" e "homens que exercem/exerceram violência na conjugabilidade" são adequados por destacar o ato, a eleição desse e a possibilidade de mudança. Nós concordamos com eles e adotaremos esses termos nesse estudo.

Consideramos importante também entender a violência para além do ato agressivo, para compreendê-la dentro de uma dinâmica e uma vivência conjugal inseridas em um contexto social, não como uma agressão isolada. Ao adotarmos essa perspectiva, vamos em determinados momentos nos referir a "homens em dinâmica de violência conjugal"; "homens em situação de violência conjugal"; ou "homens em vivência de violência conjugal" para frisar a relação e o seu potencial de superação e transformação, mas sem deixar de nos atentarmos para a responsabilização pelo uso da violência.

Acreditamos que esses termos facilitam a escuta desses homens como seres humanos, favorecem a percepção de suas necessidades e dos aspectos que também lhes aprisionam à relação conjugal marcada pela violência. A partir dessa visão, podemos compreender melhor algumas pesquisas e estatísticas sobre a violência conjugal, pois elas mostram as diversas consequências deletérias para todos/as envolvidos. A adoção dessa postura nos remete a outra questão fundamental: entender como os próprios homens percebem a violência conjugal.

\section{Dimensões da violência conjugal: necessidade de também enxergar os homens}

A violência atinge uma parcela significativa da população, mesmo se considerarmos que talvez a maior parte das pessoas nunca foi contabilizada nas estatísticas (Toneli et al., 2010). As mulheres e os homens têm problemas psicossociais e de saúde devido à violência conjugal, ainda 
que sofram essas consequências de diferentes modos (Alvarenga, 2012; Araujo, 2012; Couto \& Schraiber, 2005; Medeiros, 2010; Oliveira, 2015; Oliveira \& Gomes, 2011; Randle \& Graham, 2011).

Dentre as diversas consequências da violência, as mais temíveis e trágicas são os feminicídios, seja no caso de assassinato de mulheres ou de homicídio de mulheres seguido de suicídio do homem. O feminicídio é entendido como homicídios de mulheres em decorrência da violência de gênero, ou seja, quando se mata as mulheres devido a desigualdades de gênero; quando se mata pelo fato de ser mulher e de se presumir a sua posse (Ávila et al., 2014; Brasil, 2015; Costa \& Grossi, 2009; Instituto Patrícia Galvão/Data Popular, 2013; Macdonald, Monaem, Sliwka, Smith \& Trezise, 2010; Medeiros, 2015; Meneghel \& Hirakata, 2011; Teixeira, 2009; Williams, 2001; Yamamoto \& Colares, 2015).

O Mapa da Violência no Brasil (Waiselfisz, 2012) revelou que 91 mil mulheres foram assassinadas nos últimos 30 anos, sendo mais de 43 mil na última década. Esses dados mostraram que houve um aumento de $216 \%$ de homicídios femininos entre 1980 e 2010 . A taxa de homicídios femininos passou de 2,3 para 4,6 mortes a cada 100 mil mulheres nesse período. Cresceu muito mais que a taxa dos homicídios em geral, que cresceram 124\% entre 1980 e 2010.

Dentre as mulheres, quase $68,8 \%$ foram mortas dentro de casa e, se considerarmos as vítimas na faixa etária de 20 a 49 anos, $65 \%$ foram executadas pelos parceiros ou ex/parceiros. Geralmente, os assassinos são pessoas com quem a mulher teve algum laço de confiança e afeto. Quanto aos instrumentos utilizados, predominou o uso de armas brancas (tais como faca) seguidas de armas de fogo. No assassinato de homens, predomina estas armas, em 72,4\% dos casos (Waiselfisz, 2012; Instituto Patrícia Galvão/Data Popular, 2013; Yamamoto \& Colares, 2015).

Em 2015, foi lançada a segunda edição do Mapa da Violência no Brasil com enfoque nos homicídios de mulheres (Waiselfisz, 2015a). Essa edição confirmou o crescimento dos dados alarmantes de feminicídio em relação ao primeiro Mapa (Waiselfisz, 2012): o Brasil passou da $7^{\mathrm{a}}$ para o $5^{\text {a }}$ colocação dentre os países com maior número de homicídios femininos no mundo, com taxa de 4,8\% homicídios por 100 mil mulheres. A quantidade de mulheres assassinadas passou de 3.937 em 2003 para 4.762 em 2013, representando um aumento de 21\% no período de dez anos. Em média, 13 mulheres foram assassinadas por dia nessa década. Esse aumento foi maior para a população de mulheres negras, as taxas de mulheres e meninas negras assassinadas cresceu de $22,9 \%$ em 2003 para 66,7\% em 2013.

O dado real é que os homens morrem mais no contexto público, e as mulheres no privado. Os dados mostram que os fatores de vulnerabilidade aos homicídios são diferentes entre homens e mulheres. Há uma peculiaridade "das mortes violentas de mulheres: a conexão com o fenômeno da 
violência doméstica e familiar e a maior suscetibilidade de ser morta por instrumentos que envolvem contato próximo entre agressor e vítima e que sugerem uma desproteção maior” (Yamamoto \& Colares, 2015, p. 5).

Apenas no período entre 2003 e 2007, foram registrados 19.459 óbitos de mulheres por agressão no Brasil no Sistema de Informações sobre Mortalidade (Meneghel \& Hirakata, 2011). Essas pesquisadoras afirmam que é alarmante o índice de letalidade da violência doméstica e familiar no país, mesmo no caso de mulheres que recorreram à justiça para buscar proteção.

No período entre 2006 a 2013, 370 dentre as 462 mulheres assassinadas no estado do Rio Grande do Sul tinham Medidas Protetivas de Urgência em seu favor. Aproximadamente 95\% das mulheres assassinadas registram pelo menos uma ocorrência de estupro, lesão corporal ou ameaça de 2 a 6 meses antes do homicídio (Grossi, 2013).

Dados do IPEA (2013) revelaram que entre 2001 a 2011 não houve redução significativa das estatísticas de feminicídio no Brasil. Mais recentemente, o IPEA realizou outro estudo que mostrou que a Lei Maria da Penha contribuiu para a diminuição em aproximadamente $10 \%$ sobre a taxa de homicídio contra as mulheres dentro das residências. A quantidade de Organismos de Políticas para Mulheres - OPM ainda é muito precária no Brasil (Cerqueira, Matos, Martins \& Pinto Júnior, 2015). O Brasil ainda não conseguiu implementar mecanismos efetivos para avaliar o risco e combater os números alarmantes de feminicídios (Ávila et al., 2014; Bandeira, 2009; Medeiros, 2015; IPEA, 2013).

Infelizmente o feminicídio não é um fenômeno exclusivo da realidade brasileira. PonceAntezana, (2012) aponta as estatísticas trágicas do governo da Espanha no "Relatório sobre vítimas fatais por violência de gênero". No período entre 2003 e 2010, aconteceram 566 assassinatos de mulheres. A violência doméstica figurou entre as 10 principais causas de morte no mundo de mulheres com idade de 15 a 44 anos (Instituto Patrícia Galvão/Data Popular, 2013; Krug et al., 2002; OMS, 2005; Yamamoto \& Colares, 2015). O relatório da Secretaria Geral das Organizações das Nações Unidas - (ONU, 2006) mostrou que os assassinatos de mulheres ocorrem em todos os países. O relatório chama atenção dessa forma de violência contra as mulheres e aponta para a impunidade como um fator central para sua alta incidência em todo o mundo.

O contexto e o cenário de assassinatos de homens e mulheres são bem distintos. Os dois tipos de homicídios são graves e alarmantes. Dessa forma, requerem políticas públicas e ações diferenciadas (Yamamoto \& Colares, 2015). Ávila et al. (2014) defendem que "ser mais eficiente no enfrentamento à violência doméstica é um imperativo humanitário" (p. 22). Uma grande conquista nesse sentido foi a promulgação da Lei 13.104/15, conhecida como a Lei do Feminicídio, 
que incluiu o feminicídio como crime hediondo e prevê penas mais severas nesses casos (Brasil, 2015).

O Brasil foi o $15^{\circ}$ país da América Latina a implantar uma lei específica para alterar a legislação penal e para nomear e qualificar o feminicídio de forma diferenciada dos outros homicídios (Yamamoto \& Colares, 2015). Apesar desse avanço, ainda é preciso aprimorar as políticas públicas e aumentar o número de equipamentos para a efetiva aplicação da Lei Maria da Penha, e, consequentemente, da Lei do Feminicídio.

Identificar as consequências da violência conjugal para as mulheres é fundamental, mas é preciso também conhecer a perspectiva de homens sobre a violência, especialmente quando eles configuram como autores. O Sistema de Indicadores de Percepção Social do Instituto de Pesquisa Econômica Aplicada - IPEA (2014) realizou uma pesquisa em 3.809 domicílios de 212 municípios em todas as Unidades Federativas do Brasil para verificar a tolerância social à violência contra as mulheres em nosso país. Os dados foram alarmantes. Cerca de $42 \%$ dos brasileiros acreditam que a mulher é culpada pela violência sexual, 58\% consideram que "se as mulheres soubessem se comportar, haveria menos estupros"; e $27 \%$ concordam que a mulher deve ceder às exigências sexuais do parceiro mesmo sem estar com desejo.

Essa pesquisa ainda mostrou uma grande contradição na percepção da violência pelos brasileiros. Cerca de $91 \%$ dos entrevistados defendem a prisão para homens que batem em suas companheiras, mas $82 \%$ acreditam que "em briga de marido e mulher não se mete a colher" e $63 \%$ consideram que a violência dentro de casa deve ser discutida somente entre os membros da família (IPEA, 2014). Fica evidente o paradoxo entre a presença de velhos modelos que se misturam a percepções "socialmente corretas" acerca do tratamento a ser dado aos homens autores.

Esse estudo do IPEA mostrou estreita relação entre as questões de gênero e violência conjugal, especialmente por revelarem que as visões conservadoras e tradicionais sobre o significado de ser homem estavam altamente relacionadas ao uso da violência contra as parceiras. Apontou ainda para uma tendência à naturalização da violência, uma vez que os homens participantes não consideraram a violência contra a mulher como problema de saúde pública ou questão jurídico-legal.

Outros estudos (Costa \& Grossi, 2010; Instituto Patrícia Galvão/Data Popular, 2013; Medrado \& Méllo, 2008; Yamamoto \& Colares, 2015) revelaram que as manifestações aceitas e, geralmente, estimuladas pela própria sociedade são as portas de entrada para as violências graves, inclusive, as que atentam contra a vida de muitas mulheres e dos próprios homens. Os parâmetros sociais e os estereótipos de gênero geram paradoxos que afetam a percepção dos processos relacionais e contribuem para a naturalização da violência. 
A violência é deletéria para todas as pessoas envolvidas. Os seus efeitos são danosos às vítimas, aos autores, aos/às filhos/as e demais familiares (Brancalhone, Fogo \& Williams, 2004; Juras, 2009; Medeiros, 2010; Oliveira, 2015). Temos que avançar no sentido de parar de ficar apenas comparando quem bate ou apanha mais, quem é mais vítima ou mais autor da violência. Não estamos dizendo que as pesquisas sobre a magnitude da violência não sejam relevantes. Ao contrário, temos que conhecer a fundo o fenômeno, mas devemos ir além. Como todos/as sofrem, devemos aprimorar a atenção a ser dada aos homens, às mulheres e às demais pessoas nessa situação.

Precisamos de mais pesquisas que mostrem como ocorre a manifestação da naturalização da violência conjugal pelos homens, mesmo quando eles são autores das agressões. Somos otimistas e acreditamos que em um futuro não muito distante teremos mais conhecimentos das masculinidades nas relações conjugais marcadas pela violência. Assim, teremos melhores recursos para também enxergar as suas necessidades, para compreender a perspectiva de homens em dinâmica de violência conjugal. Urge a necessidade de clarear outras faces dessa problemática (Alves et al., 2012) e ampliar o conhecimento da relação entre a tríade: violência, masculinidades e conjugalidades.

A partir dessa visão, não podemos deixar de apontar que muitos desafios se impõem para a efetiva compreensão e intervenção nos casos de violência conjugal. Fica evidente a necessidade de problematizar e de expandir as formas de enxergar algumas características atribuídas exclusivamente à personalidade ou até mesmo à psicopatologia de homens nessa dinâmica. Consideramos fundamental uma discussão mais ampla para contextualizar também uma dimensão social a respeito da naturalização da violência em suas diversas formas, especialmente pela desresponsabilização dos homens autores e culpabilização das mulheres vítimas por meio de mitos e estereótipos sociais.

\section{Mitos, desresponsabilização de homens e culpabilização de mulheres}

Os mitos favorecem a culpabilização de mulheres, a desresponsabilização de homens e a omissão dos profissionais que atuam nos casos de violência conjugal. Temos que desconstruir os mitos a partir de uma análise baseada nas questões de gênero para evitar, inclusive, a excessiva patologização das pessoas envolvidas em dinâmicas marcadas pela violência. Urge uma reflexão mais ampla do fenômeno, indo além do binarismo sexo/gênero para questionar os paradoxos desses mitos (Butler, 2003; Rodrigues, 2005). Nesse sentido, concordamos com as ideias de Ogando (2010), que defende que:

as preocupações feministas acerca das variadas manifestações de dominação e subordinação de gênero apontam a necessidade de se desvendar como tais práticas e 
valores se enraizaram e encontraram legitimidade na sociedade (...) Essas contribuições buscaram revelar como as hierarquias de gênero não foram desafiadas, em razão da forma como as estruturas de dominação naturalizam e naturalizaram essa construção social (Ogando, 2010, p. 1).

É importante discutir como os mitos favorecem a culpabilização de mulheres vítimas e a desresponsabilização de homens autores de violência. O processo de exclusão, patologização e culpabilização da mulher é construído por meio de justificativas que dão ênfase ao papel da mulher exclusivamente na vida privada, sempre vinculado ao cuidado do lar, do companheiro e dos/as filhos/as (Ogando, 2010). Durante muito tempo a maternidade foi a principal justificativa para excluir as mulheres da vida pública (Scott, 2005). Esse argumento também serviu para fundamentar manifestações contra o sufrágio feminino, pois à época imperava a concepção de que "a mulher descuidaria das suas obrigações para com a família a partir do momento em que dispensasse seu tempo com a ida às urnas. Além disso, (...) a natureza da psique feminina e suas tendências 'levianas' e 'emotivas' como sinais do despreparo para o exercício da cidadania” (Schimidt, 2009, p. 90).

Ogando (2010) afirma que essa responsabilização exclusiva da mulher pelo cuidado pode ser entendida nas ideias de Simone de Beauvoir, que afirmava em sua obra célebre o Segundo Sexo que: "a humanidade é masculina e o homem define a mulher não em si, mas em relação a ele; ela não é considerada um ser autônomo" (Beauvoir, conforme citado em Ogando, 2010, p. 1). Assim, a identidade de um grupo visto como socialmente minoritário é atribuída pela discriminação (Scott, 2005).

Essa naturalização da condição inferior das mulheres ajuda a entender como elas ficaram e ainda ficam sem muitos direitos civis assegurados (Ogando, 2010; Pratt, 1993). Essa autora define que desde o início da construção da nação brasileira o valor da mulher era resumido à sua capacidade reprodutiva, assumindo o papel de reprodutora de cidadãos. Assim, ao restringi-la a esse papel de mães da nação "elas são precariamente outras para a nação (...) seus corpos são locais para muitas formas de intervenção, penetração e apropriação" (Pratt, p. 131). Quando a mulher descumpre qualquer expectativa social baseada em sua condição feminina, é uma forma de a sociedade e os cônjuges justificarem as agressões e culpabilizarem as mulheres pela violência conjugal.

Carvalho (2010) afirma que "é precisamente a legitimidade dessa passagem do biológico para o ontológico que o conceito crítico de gênero propõe questionar” (p. 85). A inversão da culpabilização pela violência só é possível devido à desigualdade de poder entre homens e mulheres. A constatação simplista de que todas as mulheres vítimas de violência permanecem na 
relação por gostar de apanhar é um exemplo dessa desigualdade. Scott (2005) pontua essa questão ao defender que é

devido às diferenças de poder entre homens e mulheres que as feministas têm-se referido às mulheres como uma minoria, mesmo que elas perfaçam mais da metade da população (...) a relação de causalidade se dá ao inverso: processos de diferenciação social produzem exclusões e escravizações que são então justificadas em termos de biologia ou de raça (Scott, 2005, p. 17).

Esse processo de exclusão é reiterado por meio de justificativas, inclusive da violência conjugal. A ênfase dos argumentos discriminatórios frequentemente foca na biologia, na dita "natureza" feminina ou psicopatologia da mulher. Há uma tentativa de naturalizar e minimizar toda complexidade do fenômeno da violência conjugal e de culpabilização exclusivamente da mulher. Brah (2006) afirma que "as feministas não ignoram a biologia das mulheres, mas questionam ideologias que constroem e representam a subordinação das mulheres como resultado de suas capacidades biológicas" (Brah, 2006, p. 342).

O problema não são as diferenças, mas a conversão destas em diferenças ontológicas, que passam a impressão de não poder mudar por serem parte da "essência da mulher". Assim, as mulheres são julgadas como inferiores, naturais e imutáveis. Essas condições implicam na maneira como a sociedade justifica a necessidade do controle masculino sobre as mulheres (Carvalho, 2010).

Há um contexto histórico muito arraigado que contribui para que mulheres se conformem com as justificas da violência de forma passiva a com sua própria exclusão social. De acordo com Ogando (2010), a “insistência em preservar a família e restringir a ação da mulher foi algo incorporado e aceito não só pelos homens, mas pelas mulheres também (...) as próprias mulheres internalizaram seus papéis na sociedade" (p. 8). Não é permitido a elas questionarem ou desafiarem essas regras e hierarquias sociais que naturalizam as desigualdades entre homens e mulheres.

Quando alguma mulher descumpre essa expectativa social, o parceiro se sente no direito de lançar mão da violência doméstica. Mulheres podem assumir o peso de toda violência como se fossem culpadas pelas agressões sofridas. Esse fenômeno é intitulado como "internalização da opressão" (Sinclair, conforme citado em Williams, 2001). Assim, o feminismo veio como um protesto contra essa culpabilização, patologização e exclusão de mulheres com o objetivo de eliminar essas desigualdades sociais (Scott, 2005).

Ao mesmo tempo em que existe a tendência em culpabilizar e psicopatologizar mulheres, homens autores de violência também foram classificados como portadores de distúrbios mentais, em uma tentativa de desresponsabilizá-los pelas agressões. Walker (1979) afirma que os homens frequentemente são considerados como psicopatas e antissociais. Esse mito simplifica, individualiza 
e personifica a violência na figura do "agressor", deixando de considerar todas as suas outras dimensões, principalmente as sociais e culturais.

O maior problema dessa psicopatologização é que ela vai de encontro a uma tendência social dos próprios homens em situação de violência conjugal: a minimização e a desresponsabilização de seus atos. Essa naturalização da violência pode servir para a utilização de diversas justificativas de suas condutas agressivas de forma complementar - por eles mesmos, pelas ex/parceiras e pelos profissionais (Aguiar, 2009; Guimarães, 2009). Machado (2000) corrobora que há uma construção social e histórica que serviu para naturalizar e justificar a violência dos homens sobre suas ex/parceiras, pois eles se sentem no direito de controlá-las. Assim, essa autora defende que:

A história natural impôs uma autoridade urbana, letrada e masculina sobre todo o planeta, elaborando um entendimento racionalizador, extrativo e dissociativo, que suprimiu as relações funcionais e experienciais entre as pessoas, plantas e animais (...) um repertório comum a respeito dos povos selvagens e um consenso sobre a necessidade da intervenção do homem branco no mundo pós-colonial que então se esboçava (Machado, 2000, p. 284-285).

A violência conjugal é um fenômeno social com repercussão na saúde física e psicológica das pessoas. Apenas uma minoria das manifestações de violência é decorrente de problemas psicológicos com implicações sociais (Guimarães, 2009; Saffioti, 1999). Esses aspectos mostram que muito além de ser uma questão individual ou psicopatológica, existe toda uma conjuntura social e histórica que naturaliza a violência conjugal. É nesse sentido, que Del Priori (1993) descreve a importância de quebrar a justificativa para a dominação masculina utilizada pela sociedade patriarcal, que entende que a série "mulher, pecado e natureza" implica a necessidade de domesticação das mulheres pelos homens.

As agressões não podem ser justificadas apenas como perda momentânea do controle; ao contrário, é importante que homens reconheçam e assumam a responsabilidade pelos pressupostos que justificam seus atos como um dos ingredientes necessários para a interrupção da violência (Saffioti, 1999; Nichols \& Schwartz, 2007). A violência conjugal é geralmente perpetrada pelos homens em um ato consciente para, na grande maioria das situações, obter controle e poder na relação com as ex/companheiras (Saffioti, 1999).

Pontes (2004) defende que algumas correntes feministas estão revendo a lógica simplista das décadas de 1970 e 1980 de classificação psicopatológica de homens autores e mulheres vítimas para uma análise mais relacional e social do fenômeno da violência conjugal. Para essa autora, os estudos devem considerar as ambivalências vivenciadas por várias mulheres nessa situação. Pontes argumenta que existem sociabilidades diferentes de homens e mulheres no século XIX - mas não apenas nele - que só podem ser entendidas como resultado de um engate simbólico que, por ser estrutural, exige o acionamento de uma análise de tipo relacional de gênero. 
Os mitos que culpabilizam a mulher e desresponsabilizam os homens são complementares e contribuem de forma significativa para naturalizar e silenciar a violência. Os terceiros envolvidos familiares, amigos/as, comunidade e profissionais - justificam sua negligência e omissão com base na valorização da imagem do homem e no descrédito do relato da mulher. Assim, eles/as não oferecem apoio e atenção necessários a todos/as envolvidos/as, colaborando para a perpetuação da violência e para a possibilidade de ocorrer um desfecho trágico (Grossi, 1995; Ravazzola, 1998; Williams, 2001). É fundamental, portanto, identificar e desconstruir esses mitos sociais como uma forma de enfrentar a violência conjugal. A desconstrução dos mitos pode ser uma forma efetiva de prevenir e evitar a instalação de anestesias relacionais nas dinâmicas conjugais marcadas pela violência.

\section{Desconstrução dos mitos e enfrentamento à violência}

A simplificação do fenômeno da violência conjugal por meio dos mitos é uma estratégia inadequada diante da dificuldade de nossa sociedade em perceber e lidar com as diferenças, principalmente as de gênero. Joan Scott (1995) afirma que a igualdade não significa a ausência ou eliminação da diferença, mas o reconhecimento da diferença. Brah (2006) contextualiza bem a relação entre diferença/desigualdade com os aspectos discutidos a respeito dos mitos:

se refere à variedade de maneiras como discursos específicos da diferença são constituídos, contestados, reproduzidos e resignificados. Algumas construções da diferença, como o racismo, postulam fronteiras fixas e imutáveis entre grupos tidos como inerentemente diferentes. Outras construções podem apresentar a diferença como relacional, contingente e variável. Em outras palavras, a diferença não é sempre um marcador de hierarquia e opressão. Portanto, é uma questão contextualmente contingente saber se a diferença resulta em desigualdade, exploração e opressão ou em igualitarismo, diversidade e formas democráticas de agência política (Brah, 2006, p. 374).

A partir do risco da diferença se transformar em desigualdade e servir como base para a propagação dos mitos sobre a violência conjugal, Foucault (1996) nos convida a analisar criticamente os discursos difundidos por nossa sociedade. Ele ressalta que todo discurso é poder e opera sob a égide do controle. Devemos ampliar e aprofundar reflexões sobre gênero, masculinidades e conjugalidades para construir discursos que nos permitam compreender os mitos e estereótipos que deturpam a percepção de homens e de mulheres sobre o risco e o impacto da violência conjugal em suas vidas e relações.

Esse desafio é válido mesmo sabendo que a desconstrução desses mitos é difícil, pois de acordo com Foucault (1996) ela implica em criar possibilidades de romper com o discurso dominante/hegemônico. É com base nesse processo de ressignificação que poderemos alcançar cada vez mais os aspectos positivos da diferença e romper com a desigualdade, a exploração e a opressão 
para substituí-las e/ou transformá-las em igualitarismo, diversidade e outras formas mais democráticas de relações sociais e conjugais (Brah, 2006).

Esses mitos e estereótipos não são "privilégios" do senso comum. Profissionais, cientistas e filósofos importantes estão sujeitos a reproduzi-los. Carvalho (2010) afirma que vários filósofos, inclusive os mais respeitados e famosos, trataram das diferenças e desigualdades entre os sexos ao longo da história. Ela ressalta que os "filósofos não criaram as efetivas condições de desigualdade, mas muitos se empenharam em construir argumentos para legitimar e justificar tais condições" (Carvalho, 2010, p. 83-84). Percebemos que não existe uma verdade absoluta, nem mesmo no discurso científico (Foucault, 1996).

Nesse sentido, as ideias de Ogando (2010) nos alertam para o perigo da institucionalização dos mitos. Os profissionais destinados a intervir no enfrentamento da violência conjugal podem cometer verdadeiras violências institucionais contra as pessoas atendidas se não estiverem atentos às questões de gênero. Segundo, Ogando (2010):

Ao entender que práticas e valores cotidianos estão embutidos de significâncias que depreciam ou desvalorizam o papel da mulher na sociedade, o reconhecimento, ou falso reconhecimento, passa a ser a chave para efetivamente romper com estes padrões de sociabilidade que, por sua vez, são oriundos das práticas na esfera privada. Em outras palavras, é reconhecer que a força das formas de dominação desencadeia diversos padrões institucionalizados e assimétricos de interação que tanto atribuem um status particular e diferenciado para homens e mulheres quanto ofuscam as dimensões de poder neles embutidos (p. 8-9).

A dificuldade em lidar com a violência conjugal faz com que as pessoas leigas e profissionais tendam a tomar os debates de forma polarizada, simplificando e minimizando a complexidade dos temas sobre igualdade e diferença, direitos individuais e identidades de grupo (Scott, 2005). Essa autora defende que "não existem soluções simples para as questões, debatidas calorosamente, da igualdade e da diferença" (p. 12).

É importante refletir sobre esses mitos, pois eles têm impacto direto no modo em que a sociedade e os profissionais lidam com a violência conjugal. Muitas negligências e omissões são justificadas com base nesses mitos e estereótipos. O entendimento dos efeitos deletérios dos mitos é uma etapa fundamental para conseguirmos compreender melhor a relação entre os conceitos de masculinidades e o processo social de naturalização da violência por parte de homens e mulheres envolvidos/as nessas dinâmicas (Diniz \& Angelim, 2003; Guimarães, 2009).

\section{Repensando masculinidades, mitos sociais e naturalização da violência}

Os processos reflexivos podem levar à desconstrução de mitos e posturas ligadas à masculinidade hegemônica. Acreditamos na capacidade de mudanças dos homens autores.Nosso foco nesse trabalho é, entretanto, o passo anterior: compreender os fatores que aprisionam esses 
homens à violência conjugal. $\mathrm{O}$ intuito é entendermos os sentidos da violência para homens encaminhados à justiça para acessarmos os meios em que a violência foi naturalizada no processo de socialização e de construção de suas masculinidades. Consideramos ser relevante discutir como os homens manifestam a negação, minimização e a desresponsabilização da violência. Partimos do pressuposto que por meio desse processo poderemos ter mais recursos para desconstruir essa naturalização, para em seguida podermos ter reais possibilidades de promover mudanças e transformações efetivas nas relações conjugais marcadas pela violência. Esses processos podem subsidiar propostas de políticas, ações e intervenções com essa população.

Repensar a relação entre violência, masculinidades e conjugalidades é um dos passos fundamentais rumo a relações mais igualitárias no mundo. Realizamos uma breve apresentação sobre a evolução histórica do conceito de masculinidades e sobre algumas vulnerabilidades masculinas para a violência conjugal e sobre os diferentes estilos de conjugalidades. Apresentamos também como os homens que vivenciam situação de violência conjugal são vistos em nossa sociedade. As dimensões dessa violência e as formas atuais de socialização masculinas que naturalizam a violência foram brevemente problematizadas.

A organização social desigual atinge a todos e todas. Ao mesmo tempo, as pessoas tornamse vítimas e autores dos diversos tipos de violência de gênero. As várias formas de manifestação da violência, de modo especial, a violência conjugal, não podem ser explicadas apenas com base nas “... informações estatísticas, nos estereótipos culturais (...) ou nas diferenças biológicas entre os sexos (...). Restringir-se a esses níveis seria ignorar a sua complexidade e a sua raiz mais profunda” (Alves et al., 2012, p. 980).

Muitos homens podem se sentir simultaneamente aprisionados como agentes e também como vítimas de um modelo violento de socialização. Ficam reféns de exigências sociais e podem perder ou tirar a vida de outras pessoas em uma busca incessante e desgastante de afirmação e confirmação de um sexo social (Alves et al., 2012). A complexidade da violência exige ir além da compreensão tradicional que percebe o homem somente como autor e a mulher apenas como vítima. Precisamos de novos olhares sobre esses homens e essas mulheres para entender melhor a violência conjugal.

Beiras et al. (2012), Cantera (2007) e Silveira et al. (2009) defendem a ampliação das questões de gênero, de forma a ir além do gênero e da mera descrição de diferenças culturais entre homens e mulheres. Esses/as pesquisadores/as acreditam ser necessário reconhecer, inclusive, algumas limitações da perspectiva tradicional de gênero para lidar com a violência conjugal. Eles/as consideram que os princípios patriarcais não podem ser utilizados como postulação universal, pois não vão dar conta de explicar a violência em todo e qualquer tipo de relação conjugal. Esses 
princípios não contemplam, por exemplo, todas as diferenças e diversidades das relações conjugais heterossexuais, da violência nos casais homossexuais e da violência na direção mulher-homem. Nesse sentido, Beiras et al. (2012) afirmam que entender:

a questão da violência de gênero com bases nestas teorias é considerar as diferenças e particularidades de cada caso; é desconstruir o discurso dominante de fragilidade feminina e o mandato de poder, dominação e força masculina; é dar visibilidade aos aspectos excluídos ou ocultados (Beiras et al., 2012, p. 41).

Ir além do gênero não significa prescindir de reflexões acerca dos impactos do patriarcado implica em ampliar a compreensão, considerar outras questões para superar a violência conjugal e para tornar as pessoas mais livres e autônomas. Alves et al. (2012) afirmam que, para isso, dentre outras ações, é preciso "remodelar masculinidades mais flexíveis, saudáveis e pautadas no estabelecimento de relações mais igualitárias dos homens junto aos seus pares e ao sexo oposto" (p. 982).

É urgente a necessidade de inventarmos novas formas de viver as relações, de incluir o respeito e o reconhecimento do outro como formas primárias nas relações conjugais, familiares e sociais. Precisamos compreender que a violência conjugal não é um problema apenas dos homens e mulheres envolvidos em sua dinâmica, mas constitui uma questão, um desafio a ser encarado e vencido pela sociedade em geral (Alves et al., 2012; Beiras et al., 2012; Ravazzola, 2015; Saffioti, 1999; Silveira et al., 2009).

Em momento algum queremos produzir ou defender um determinismo social que justifique ou minimize a violência conjugal. Muito menos ficar em uma posição ingênua de acreditar que nenhum homem minta para manipular os profissionais. Ao contrário, queremos buscar meios de compreender a complexidade da violência para poder superá-la, mas sem culpabilizar a pessoa seja homem ou mulher, ou a sociedade.

Acreditamos na capacidade de agenciamento e de transformação das pessoas. A socialização de gênero age como mapa ou um molde, embora nem todos os homens desempenhem o padrão, ele serve como referência de masculinidades. Precisamos fazer esse exercício de integração do sujeito e entendê-lo em suas diversas dimensões sociais, pessoais e individuais (Nascimento et al., 2009; Ponce-Antezana, 2012; Separavich \& Canesqui, 2013; Teixeira, 2009).

Reconhecer essas questões sociais é um primeiro passo para superar esse padrão de socialização que aprisiona homens e mulheres em dinâmicas conjugais marcadas pela presença de violências. $\mathrm{O}$ objetivo dessa tese é justamente aproximar desses homens autores para compreender como eles expressam a naturalização da violência. Queremos entender também alguns aspectos relacionais que acontecem no íntimo dessas dinâmicas conjugais, especialmente sob o prisma da perspectiva sistêmica por meio do conceito de anestesias relacionais e da teoria do duplo-vínculo. 


\title{
Capítulo 2
}

\section{Violência conjugal e perspectiva sistêmica: aprisionamentos de homens autores}

\author{
Alguma coisa diz que é pra eu ir embora \\ E outra diz que eu quero você pra mim \\ Eu tava aqui pensando em tudo mais menos você \\ E achei tão engraçado ter prestado atenção \\ Na sua distraída intenção de me entender \\ Como se já soubesse a chave da minha prisão \\ Mas eu não poderia fugir agora \\ Você nem deveria tentar assim \\ Alguma coisa diz que é pra eu ir embora \\ E outra diz que eu quero você pra mim \\ Nem sei se eu quero pensar mais nada. Nada. \\ Tudo que eu tinha larguei pelo chão de uma outra estrada \\ (Música: Você Não Poderia Surgir Agora - Roberta Sá)
}

A violência conjugal é um dos crimes com mais elevada taxas de reincidências. A chance de reinstalação da violência é grande, seja na mesma relação ou em relações futuras, quando ocorre a separação do casal (Manita, 2008). Tramas do padrão relacional precisam ser desvendadas para que se possa entender como é difícil e complexa a elaboração de um pedido de ajuda por parte das mulheres e dos homens. Essas tramas contribuem para que os dois fiquem aprisionados a uma relação conjugal marcada pela violência. A aplicação de teorias sistêmicas aos casos de violência conjugal pode contribuir para uma melhor compreensão desse fenômeno.

Apresentamos nesse capítulo duas teorias sistêmicas que podem nos auxiliar na compreensão da violência conjugal. Abordamos as contribuições do conceito de anestesias relacionais (Ravazzola, 1997, 1998, 2007, 2015) e da teoria do duplo-vínculo para o estudo desse fenômeno (Angelim, 2009; Angelim \& Diniz, 2010; Mahmoud, 2003; Watzlawick, Beavin \& Jackson, 1967/2007). Essas teorias incluem em suas proposições outras visões clássicas e importantes sobre a violência, tais como as questões de gênero e a teoria do ciclo da violência (Cantera, 2007; Diniz, 2011, 2013; Schmidt, 2010; Walker, 1979, 1999; Walker, Duros \& Tome, 2007).

É nosso entendimento que a discussão sobre essas perspectivas sistêmicas podem fornecer ferramentas fundamentais para elucidar parte do "mistério" da permanência e manutenção de um relacionamento marcado e estruturado pela violência, especialmente por analisar como os processos sociais de desresponsabilização do homem e de culpabilização da mulher repercutem no íntimo da relação conjugal. Essa discussão pode oferecer subsídios e mais instrumentos para os/as profissionais que atuam com homens e mulheres em situação de violência conjugal (Angelim, 2009; Angelim \& Diniz, 2010). Para que essa ampliação do conhecimento na área efetivamente ocorra, 
devemos incluir os homens como sujeitos nas análises da violência à luz dessas perspectivas sistêmicas.

\section{Homens, violência conjugal e perspectivas sistêmicas}

Diversos estudos (Diniz, 2011; Oliveira \& Gomes, 2011; Teixeira, 2009) apontam a importância de se explorar mais as dimensões afetivas das conjugalidades marcadas pela violência rumo a uma abordagem mais relacional e sistêmica, que seja ancorada pelas questões de gênero. É fundamental aprofundar os estudos sobre as bases psicossociais dessas relações conjugais. Essas bases constituem mais um elemento para compreender o complexo fenômeno da violência, mas devem ser analisadas em conjunto com outros aspectos sociais, culturais e individuais.

Gregori (1993) afirma que a violência conjugal não se modifica atuando-se apenas no nível da consciência, da informação, da sugestão ou imposição de penas. Para essa autora, urge o desenvolvimento de "novas linhas de investigação que sejam capazes de apreender as transformações culturais que culminam em modificações das relações de gênero" (p. 199).

Um salto nas pesquisas sobre as relações de gênero seria olhar para dentro das relações, para entender as cenas, as dinâmicas relacionais e os/as personagens, sem perder, todavia, a contextualização social da violência (Gregori, 1993). O estudo das masculinidades e da violência conjugal sob o prisma de perspectivas sistêmicas pode contribuir nesse sentido, especialmente para ajudar no entendimento de como as pessoas atualizam as questões sociais nos âmbitos afetivo, interacional e familiar (Diniz \& Angelim, 2003; Diniz, 2003; Medrado et al. 2011).

Ravazzola (2007) também defende a somatória da visão sistêmica aos estudos de gênero. Essa perspectiva tem grande potencial para ser utilizada com os homens, mulheres e as famílias afetadas pela violência. Outros/as autores/as corroboram essa conexão ao adotarem uma abordagem clínica integrada a uma perspectiva sistêmica feminista (Angelim, 2004; Diniz, 2011; Pondaag, 2003). Angelim reforça a importância dessa integração:

A integração do pensamento feminista com as terapias de família de base sistêmica tenderá a uma abordagem mais complexa da violência doméstica, especialmente da violência conjugal, por considerar os fatores de gênero e as teorias de compreensão das dinâmicas dos relacionamentos interpessoais e suas estruturas. A apropriação da reflexão feminista permite a elucidação do processo histórico de reconhecimento da condição da mulher e das práticas patriarcais que legitimam a violência doméstica. Na compreensão sistêmica da violência entre casais existe uma distinção entre as práticas terapêuticas que se dispõem a compreender a violência tendo em vista as críticas feministas e aquelas que se dispõem a realizar as intervenções independentemente das críticas feministas (Angelim, 2004, p. 30).

O estudo das anestesias relacionais e das dinâmicas duplo-vinculares pode possibilitar uma ampliação do conhecimento do que acontece no íntimo das relações conjugais marcadas pela 
presença de violência. Essa ampliação pode ser fundamental para conhecer melhor o fenômeno e desenvolver mais pesquisas e programas de intervenções com os homens, assim como com as mulheres (Manita, 2008).

A ênfase nos estudos das mulheres vítimas foi importante para evidenciar as inúmeras consequências deletérias da violência para a população feminina. Essa ênfase foi relevante para evidenciar como as mulheres ficam presas a essa dinâmica. Ao mesmo tempo, a pouca quantidade de estudos voltados para a população masculina contribuiu para a invisibilidade ou exclusão das necessidades dos homens autores de violência.

O objetivo desse capítulo é problematizar a inclusão dos homens para compreender melhor como ambos - homens e mulheres ficam presos/as à relação e como os dois contribuem para a perpetuação da dinâmica relacional. O estudo de anestesias relacionais e da teoria do duplo-vínculo é fundamental para efetivamente inserir as masculinidades no entendimento da dinâmica conjugal marcada pela violência. Vale ressaltar que o entendimento da contribuição da mulher na manutenção da relação é bem diferente de responsabilizá-la pelas agressões cometidas pelo parceiro.

Começamos com a apresentação do conceito de anestesias relacionais, condição proposta pela psiquiatra e terapeuta familiar argentina Maria Cristina Ravazzola (1997). Descrevemos como o processo social de naturalização da violência influencia na instalação de verdadeiras anestesias relacionais na dinâmica conjugal marcada pela violência. Esse conceito é fundamental para entendermos como muitos homens e mulheres não conseguem sequer perceber que estão naturalizando a violência, que estão se anestesiando e deixando de sentir os impactos das agressões. As anestesias relacionais são importantes para compreendermos alguns dos aspectos da negação, minimização, justificação e/ou desresponsabilização de homens autores por suas agressões.

\section{Anestesias relacionais: homens também não veem que não veem a violência}

A violência conjugal é um fenômeno complexo e aterrorizante. Conhecer esse fenômeno a fundo significa enfrentar o desafio de entender dimensões da dinâmica relacional marcada pela violência, além de compreender o que acontece no íntimo de cada pessoa que participa da relação conjugal (Diniz, 2011, 2013; Krug et al., 2002; Santos \& Moré, 2011).

A violência conjugal constitui um dos fenômenos sociais mais absurdos e inaceitáveis, no entanto, tem grande incidência e tende a se perpetuar na relação (Angelim, 2009; Diniz, 2011, 2013; Ravazzola, 1997; Soares, 2005; Zuma et al., 2009). Essa violência é algo inesperado e imprevisto para as pessoas envolvidas, mesmo que, em muitos casos, seja evidente para profissionais e pessoas próximas ao casal. A violência inverte o papel da conjugalidade: de proteção para o de abuso (Ravazzola, 1998, 2015). 
A partir de seu trabalho com mulheres, homens, casais e famílias em situação de violência, Ravazzola $(1997,1998)$ criou um dos conceitos mais importantes para ajudar a compreender como uma relação conjugal marcada pela violência se perpetua. Trata-se do conceito de anestesias. A autora baseou-se no paradigma sistêmico da terapia de casais e de família para desenvolver essa teoria. Ampliou, assim, a compreensão da violência - saiu de uma visão intrapsíquica para também incluir a dinâmica relacional e aspectos sociais.

As anestesias são ideias, sentimentos e ações que contribuem para a permanência de mulheres e de homens na situação de violência conjugal, especialmente por negarem ou minimizarem o impacto das agressões em várias áreas da vida das pessoas envolvidas (Ravazzola, 1997). Esse conceito é utilizado por diversos profissionais e pesquisadores atualmente (Aguiar, 2009; Angelim, 2009; Guimarães, 2009; Guimarães, Silva \& Maciel, 2007; Guimarães, Diniz \& Angelim, no prelo; Macedo, 2013; Magalhães, 2011; Medeiros, 2010; Pondaag, 2009; Ribeiro \& Costa, 2007).

O processo de construção de anestesias ocorre de forma sistêmica com influência de questões sociais e culturais sobre a dinâmica familiar e conjugal (Ravazzola, 1997, 1998). Vamos discutir brevemente o contexto social de instalação de anestesias nas relações conjugais por meio da naturalização da violência sob a influência de mitos sociais. Em seguida, discutiremos como essas anestesias se revelam nas conjugalidades e favorecem a perpetuação da violência.

\section{Mitos e naturalização da violência: bases sociais para instalação de anestesias relacionais}

As dinâmicas relacionais envolvendo conjugalidades, violências e gênero são permeadas por mitos sociais. Esses mitos contribuem para a naturalização das violências conjugais, especialmente para a culpabilização das mulheres e a desresponsabilização dos homens. Essa naturalização favorece a perpetuação das violências e tem grande impacto em pessoas envolvidas nas relações marcadas pela violência.

A discussão sobre os mitos sociais é importante para evitar a essencialização de homens, mulheres e da relação conjugal marcada pela violência (Diniz, 2013; Diniz \& Angelim, 2003; Guimarães, 2009; Grossi, 1995). As diferenças entre homens e mulheres sempre existiram e sempre existirão. Entretanto, há problema quando a diferença se transforma em desigualdade. De acordo com Brah (2006), a "grande questão é saber como a diferença é definida. Atuam as percepções da diferença como meio de afirmar a diversidade ou como mecanismo de práticas excludentes e discriminatórias?" (p. 365).

Butler (2003) afirma que é preciso compreender que existem outras possibilidades para mulheres e homens envolvidas/os na dinâmica conjugal marcada pela violência além desses mitos e estereótipos. Temos que analisar esses mitos para ampliar e emancipar esses discursos reducionistas 
e termos possibilidades de construir novos valores (Diniz, 2013). Foucault (1996) lembra que os discursos são permeados por sistemas de controles, alguns marcados por procedimentos de exclusão. Esses discursos criam regras e a própria realidade, ou seja, o discurso é poder.

Pessoas em situação de violência conjugal foram e continuam sendo extremamente estereotipadas, discriminadas e violentadas tendo como base essas desigualdades de gênero. É importante rever esses estereótipos sociais e quebrar os paradoxos que simplificam o fenômeno da violência e ainda presumem, fixam e restringem os sujeitos (Butler, 2003).

A violência conjugal se perpetua e se naturaliza por meio de mitos e estereótipos sociais criados pela cultura. Esses mitos geram discursos, distorções, silêncios e preconceitos, que permeiam o imaginário social - as pessoas em situação de violência e profissionais não estão imunes a eles. A identificação desses mitos é importante para que se possa intervir de maneira adequada e evitar a instalação e a manutenção de relações íntimas marcadas pela violência. Tornase possível compreender melhor porque as agressões acontecem; como realmente afetam as pessoas envolvidas e como é possível desenvolver ações para interrompê-las, superá-las ou transformá-las (Diniz, 2013; Diniz \& Angelim, 2003; Grossi, 1995; Walker, 1979).

Diniz e Angelim (2003) definem os principais aspectos dos mitos em torno da violência. Para esse/a pesquisador/a, é necessário entender os significados desses mitos, que permeiam:

as ideias preconcebidas, as deduções preconceituosas, os boatos e as representações falsas, muitas vezes ilusórias e infundadas, que nos levariam a conclusões apressadas na compreensão dos fenômenos de violência. O perigo está no fato de que esses mitos acabam por influenciar concepções e por estabelecer parâmetros para intervenções quer seja em nível psicoterapêutico, médico, legal e/ou de assistência social que desvalorizam e deslegitimam as queixas das pessoas envolvidas em casos de violência (p. 21).

Muitas explicações simplistas e descontextualizadas foram dadas para tentar achar uma relação de causalidade da violência, desconsiderando a sua natureza social e complexa. Pobreza, álcool, estresse, psicopatologias, dentre outras foram criadas e perpetuadas pela sociedade. Entretanto, esses mitos foram e ainda são utilizados para favorecer a continuação da dinâmica marcada pela violência (Diniz \& Angelim, 2003).

Alguns dos principais mitos que foram criados sobre homens e mulheres em contexto de violência conjugal são: "mulheres vítimas de violência conjugal são masoquistas, gostam de apanhar ou provocam o parceiro"; "homem que bate em mulher é louco"; "violência conjugal acontece apenas com pessoas de baixa renda e pouca instrução"; "O álcool é a maior causa da violência conjugal”; "a mulher continua com o agressor porque gosta de apanhar"; "tapinha de amor não dói”; "a mulher costuma mentir sobre a violência"; "homem que agride sua parceira é violento em todas as relações e o tempo todo"; "uma vez vítima, pra sempre vítima. Uma vez agressor, pra 
sempre agressor"; "após o casamento os homens cessam a violência”; "os filhos precisam conviver com o pai, mesmo se este for violento"; "em briga de marido e mulher ninguém mete a colher" (Guimarães, 2009).

Scott (2005) aponta para o perigo dessas explicações simplistas, pois quando ocorre "a redução de um indivíduo a uma categoria é, ao mesmo tempo, devastador e embriagador. Como objeto de discriminação, alguém é transformado em um estereótipo" (p. 19). Geralmente, essa discriminação está baseada na desigualdade de gênero, raça e classe social e, no contexto da violência conjugal, é revelada por meio da desresponsabilização de homens autores e da culpabilização de mulheres vítimas. Diniz (2013) chama atenção para os danos causados pela perpetuação desses mitos sociais:

A presença de mitos sociais, tais como o popular "mulher gosta de apanhar", reflexo da atribuição de papéis de gênero, afeta o modo como mulheres que vivem em situação de violência são tratadas. Esse processo de perpetuação social de mitos e estigmas em relação às mulheres tem impacto na construção identitária das mulheres: afeta a autoestima e gera uma tendência a autodesvalorização. A esse processo de internalização das prescrições normativas, Soihet (1999) denominou de violência simbólica - as mulheres não têm um discurso próprio sobre sua identidade. Mulheres, vêm, ao longo da história, internalizando os discursos institucionais - do Estado, da Igreja, das ciências, da escola, etc. - produzidos sobre elas. A falta de uma voz própria provoca a internalização das prescrições normativas de forma tão intensa que elas se tornam incapazes de questionar esses discursos e de subverter a ordem identitária e a ordem social que eles impõem (Diniz, 2013, p. 209).

Essa reflexão de Diniz (2013) sobre o impacto dos mitos na construção identitária de mulheres pode ser transposta para os homens. Eles também são marcados pelos mitos que constroem a masculinidade hegemônica e podem ter dificuldade de questionar e refletir sobre esses mandatos sociais e discursos sobre as masculinidades.

O fato é que os mitos sociais são atualizados nas relações conjugais e familiares (Diniz, 2013; Diniz \& Angelim, 2003; Medrado et al., 2011). É preciso uma maior conscientização e sensibilização de profissionais e da sociedade sobre o impacto dos mitos na violência para não desresponsabilizar os homens e culpabilizar exclusivamente as mulheres envolvidos/as na dinâmica relacional marcada pela violência (Ravazzola, 2015).

A sociedade precisa voltar a se indignar para sair da anestesia em relação à violência. Dessa forma, pode haver conversão de valores e construção de mudanças em todos os âmbitos da cultura para percebemos plenamente os aspectos sociais e relacionais que perpassam a violência (Ravazzola, 2015). A partir da contextualização de como os mitos sociais interferem na manutenção da violência conjugal, podemos avançar na discussão sobre como a violência é naturalizada na dinâmica conjugal por meio de anestesias relacionais. 


\section{Anestesias relacionais e dificuldade de homens em perceber a violência}

Ravazzola (1997, 1998, 2015) afirma que as anestesias relacionais aparecem em oposição à reação natural que as pessoas geralmente têm ou deveriam ter quando se deparam ou sofrem violência em seu cotidiano. A resposta esperada de pessoas que entram em contato com uma situação de violência social ou familiar - sejam como testemunhas ou como diretamente envolvidas - é sentir dor, indignação, raiva, impotência e vergonha. A experiência do mal-estar levaria a algum tipo de reação no sentido de interrompê-la. A presença das anestesias impede ou dificulta essa reação.

Cabe então perguntar: como as pessoas passam da indignação à anestesia diante de várias formas de violência conjugal e familiar? A dificuldade em nomear essa violência constitui um fator que contribui para isso. A ação violenta é um fenômeno inesperado e aterrorizante para os membros do casal e, dessa forma, homens e mulheres envolvidos/as nessas dinâmicas não conseguem ou têm dificuldade para dar nomes adequados ou definir as agressões como violência. Nesse contexto, as pessoas não percebem os atos como realmente acontecem. Assim, a anestesia acontece com tanto êxito em alguns casos que o mal-estar deixa de ser sentido. Essa dinâmica ajuda a entender como muitas mulheres contam os seus dramas sorrindo, mesmo quando a violência é extrema. Nesses casos, pode haver uma verdadeira dissociação entre os sentimentos e os fatos, culminando em uma negação da violência (Angelim, 2009; Guimarães, 2009; Guimarães et al., 2007; Ravazzola, 1997).

Esse padrão de repetição da conduta violenta só é possível pelo fato de que as pessoas envolvidas "não veem que não veem" as agressões e seguem uma lógica na qual percebem como coerente. Assim, elas não conseguem ter consciência do significado da violência e de suas consequências. Essas pessoas também não enxergam suas próprias condutas de justificação, minimização e negação. O processo de naturalização da violência leva a uma verdadeira anestesia, ou "duplo cego" (Ravazzola, 1997).

O processo de construção de anestesias acontece de forma sistêmica por meio da influência de diversas questões sociais e culturais sobre a dinâmica familiar e conjugal. Essa dinâmica implica a existência de três atores: "abusador", "vítima" e "contexto reforçador ou testemunhas". Cada um/a, com seu modo de pensar, sentir e agir contribui para que a situação permaneça e o ciclo de violência se repita indefinidamente (Ravazzola, 1997, 1998).

O homem autor de violência geralmente contribui da seguinte forma: sente-se vítima do comportamento da mulher ou dos/as filhos/as; teme a independência de sua ex/parceira; tem dificuldade de perceber os sentimentos dos outros, em especial da parceira; sente que deve controlar a ação da ex/companheira - o homem é o chefe da casa e tem que ser obedecido; acha que não necessita de ajuda ou autoconhecimento. Esses fatores dificultam o reconhecimento da violência e 
favorecem que homens lancem mão de diversas justificativas para naturalizar as agressões (Aguiar, 2009; Macedo, 2013; Ravazzola, 1997, 1998).

A mulher que vive em um contexto de violência tende a considerar-se inferior e secundária e a crer na importância de viver apenas para os outros, principalmente seus/uas filhos/as e parceiro. Ela geralmente justifica a violência sofrida por achar que cometeu algum deslize, que se comportou de forma errada, levando-a a pensar que o parceiro não é responsável pelo abuso. Ela pode sentir que não tem poder sobre sua própria vida e vê o companheiro como autoridade - acredita e valida o discurso dele. Por outro lado, sente vergonha e culpa pela violência sofrida e crê que ninguém de fora da conjugalidade pode ajudá-la. Assim, pode só lhe restar permanecer no relacionamento e cuidar do parceiro para evitar novas agressões (Macedo, 2013; Medeiros, 2010; Ravazzola, 1997, 1998). Diniz (2013) chama atenção para o paradoxo afetivo presente nessas relações:

Nas relações violentas, é comum entre as mulheres o discurso de que elas precisam aguentar firme e ajudar o companheiro. Outras vezes é mencionada a sensação de que uma pessoa não consegue viver sem a outra. Cada cônjuge nutre pelo outro sentimentos de amor e de raiva, de carinho e frustração. Esse paradoxo afetivo acaba deixando a pessoa confusa, insegura e gera dificuldade em cada um dos envolvidos de avaliar corretamente o que sente pelo outro e de perceber dimensões da dinâmica relacional à sua volta. Tanto o valor sócia quanto o valor pessoal da relação dificultam uma apreciação correta da gravidade da dinâmica relacional e contribuem para a dificuldade de nomeação da violência como tal (Diniz, 2013, p. 199).

O contexto reforçador geralmente é composto também por terceiros que estão direta ou indiretamente envolvidos na dinâmica conjugal marcada pela violência - familiares, vizinhos, amigos, profissionais, comunidade, igreja etc. Geralmente, essas pessoas têm melhores condições para ajudar na resolução desse problema. Entretanto, muitas vezes elas também negam, minimizam, justificam a violência. Essas pessoas também podem ficar anestesiadas diante da vivência ou do testemunho das agressões. Elas podem inadvertidamente, em muitos casos, incentivar a permanência na relação mesmo quando a violência é extrema e crescente (Ravazzola, 1997, 1998).

Essas anestesias possuem significativa dimensão relacional e surgem como reflexo de questões sociais e culturais mais amplas. Guimarães (2009) as denominaram de "Anestesias Relacionais". As anestesias relacionais são uma das formas como as questões sociais, principalmente as de gênero, se manifestam no cotidiano das relações conjugais e familiares. Ravazzola (1997) afirma que a análise comparativa das anestesias de mulheres e de homens em uma dinâmica conjugal permite identificar a presença de algumas coincidências e complementaridades em diversos níveis. Tais coincidências e complementaridades contribuem para sustentar e justificar a violência, permitindo e contribuindo para que ela se repita, cresça e se perpetue. 
Decorre daí a importância da intervenção de terceiros envolvidos para ajudá-los/as a revisar, desafiar e refletir sobre suas ideias, sentimentos e ações, bem como para reavaliar as dinâmicas e estruturas relacionais, assim como as dimensões do contexto social que sustentam a violência conjugal na relação (Ravazzola, 1997). Torna-se fundamental, portanto, identificar as anestesias relacionais que impedem mulheres e homens de saírem do relacionamento ou de superarem a violência e permanecer na relação, quando não desejam o rompimento do vínculo.

A intervenção de terceiros deve ajudar a "desanestesiar" esse sistema. Mulheres vítimas precisam ser ajudadas a retomar o mal-estar e o medo. Os homens autores precisam voltar ou começar a perceber o impacto de seus atos, precisam aprender a considerar o sofrimento e as necessidades da ex/parceira. Desanestesiar e retomar a consciência desses afetos são passos importantes para as pessoas envolvidas começarem a reagir à dinâmica de violência. Deve-se promover intervenções que permitam a ambos os cônjuges refletir sobre o papel da violência no relacionamento e sobre a necessidade de mudança para quebrar o ciclo de violência (Ravazzola, 1997).

As intervenções realizadas no contexto da Justiça em casos de violência conjugal podem ser úteis para ajudar as pessoas envolvidas nessa dinâmica a identificarem e revisarem essas anestesias. Lamentavelmente, em muitos casos essas intervenções ainda são marcadas pela incompreensão da demanda das mulheres vítimas, bem como das necessidades dos homens autores de violência (Diniz, 2011; Magalhães, 2011; Medrado \& Méllo, 2008; Porto \& Costa, 2010; Soares, 2005). Os/as profissionais tendem a exigir um claro posicionamento das mulheres para a permissão da persecução penal do parceiro ou para arquivar o processo judicial. Muitos profissionais podem esperar também que os homens tenham capacidade de reconhecer a violência, as suas próprias necessidades e a importância da intervenção (Aguiar, 2009; Guimarães, 2009; Magalhães, 2011).

\section{Anestesias relacionais e seu papel na conjugalidade marcada pela violência}

Anestesias relacionais estão presentes em muitas conjugalidades marcadas pela violência e têm um papel importante na naturalização das agressões. O conceito de naturalização da violência é importante por ser um fenômeno social que impede ou diminui a capacidade de percepção da violência pelas pessoas envolvidas nessas dinâmicas. As anestesias relacionais produzem ou reforçam essa naturalização no âmbito da conjugalidade. Entendemos que as anestesias se revelam na relação por meio dos processos de negação, minimização e desresponsabilização de homens e mulheres.

As anestesias dificultam a percepção e a reflexão sobre a violência e podem favorecer o aprisionamento de ambos à dinâmica conjugal marcada pela violência (Angelim, 2009; Angelim \& Diniz, 2010). Ravazzola $(1997,1998)$ afirma que as pessoas em situação de violência apresentam 
verdadeiras dissociações produzidas pelas anestesias. Há uma dissociação entre os seus sentimentos, ações e comportamentos.

Mulheres podem passar a negar a situação, a minimizá-la indo até ao ponto de não serem capazes de agirem em sua própria defesa, necessitando de uma intervenção externa para ajudá-las. Homens podem justificar seus atos por meio de racionalizações e, assim, ficam impedidos de refletir sobre suas crenças sociais. Eles também podem negar ou minimizar a violência cometida. É importante ressaltar que essa dissociação não é intrínseca ao indivíduo. A socialização de gênero influencia diretamente na forma com que homens e mulheres constroem as anestesias relacionais e enxergam a violência conjugal.

Identificar padrões de socialização constitui uma etapa importante para compreender o mecanismo de naturalização da violência como uma construção social. Os modelos de socialização internalizados favorecem para que as pessoas envolvidas "não vejam que não veem" as agressões e não consigam ter consciência do significado das violências e de suas consequências em suas vidas. As pessoas envolvidas também não enxergam suas próprias condutas de naturalização.

O processo de naturalização da violência nos ajuda a compreender a instalação gradual de verdadeiras anestesias relacionais (Ravazzola, 1997). Mais do que um ato intencional de negar, minimizar, justificar ou se desresponsabilizar pelas agressões, muitos homens e mulheres não conseguem sequer perceber que estão naturalizando a violência, que estão se anestesiando e deixando de sentir os impactos das agressões.

A naturalização é um processo muito complexo e presente nas relações conjugais. É um meio de banalizar a violência, no qual as pessoas não conseguem enxergar a dimensão dos riscos e das consequências para todas as pessoas envolvidas. A naturalização é caracterizada prioritariamente pela negação, minimização e desresponsabilização. Essas características dificultam a percepção ou reconhecimento da violência para quem a pratica, quem a sofre ou quem a testemunha. No entanto, esse processo de naturalização ainda é inadvertidamente atribuído à personalidade ou à psicopatologia de homens autores de violência ou vista como mera mentira de alguns homens para se livrarem de processo judicial (Aguiar, 2009; Angelim, 2009; Brancalhone et al., 2004; Guimarães, 2009; Lila, Gracia \& Herrero, 2012; Nascimento, Gomes \& Rebello, 2009; Ravazzola, 1997, 1998, 2007, 2015; Silveira et al., 2009; Soares, 2005).

A naturalização da violência pelos homens pode ser uma característica do processo de construção da identidade de gênero das masculinidades (Beiras et al., 2012). É fundamental inserir os contextos de vida e os processos de socialização para pensar a naturalização utilizada pelos homens autores de violência. A participação da família e da cultura tem considerável influência em sua instalação e manutenção. As construções sociais contribuem significativamente para a produção 
de relações desiguais e opressivas entre as pessoas, e, se manifestam de modo particular nas conjugalidades (Silveira et al., 2009; Toneli et al., 2010).

Em vários contextos - já que a violência conjugal e familiar está presente em todas as classes sociais - cabe um trabalho de reflexão, questionamento e também de criação e construção de formas saudáveis de convivência entre os sexos. É inegável que tanto homens quanto mulheres minimizam, negam, mas os danos dessa naturalização são maiores para quem recebe a violência. $\mathrm{O}$ fato lamentável é que a violência conjugal ainda tem permissão social para existir e se manter! Tal naturalização das violências dificulta a sua percepção pelos envolvidos e pela sociedade como um todo (Nascimento et al., 2009; Silveira et al., 2009; Toneli et al., 2010).

Fávero (2010) afirma que a socialização masculina é contraditória. O mesmo sistema que marca e brutaliza os homens, ao mesmo tempo lhes confere privilégios e poder. As consequências desse condicionamento paradoxal são gravíssimas e repercutem em toda a sociedade. Esse sistema contribui para naturalizar a associação da masculinidade à agressividade e faz com que muitos homens suprimam suas necessidades, seus sentimentos e outras formas de expressão de afeto. Esse processo pode resultar também na presença de insegurança e de autodesvalorização constante.

Há uma tensão permanente entre "ser macho" e "ser masculino", que impulsiona os homens a desenvolverem várias reações violentas contra outros homens e mulheres e contra si mesmos. Forma-se, assim, a "tríade da violência” masculina (Kaufman, conforme citado por Fávero, 2010):

- Violência dos homens contra mulheres;

- Violência dos homens contra outros homens;

- Violência dos homens contra si mesmos.

Há um estresse em ter que aderir e exercer o papel de gênero referente às normas masculinas. Esse comprometimento irrestrito de adesão à identidade masculina está associado a elevados níveis de agressão, preconceito sexual, como por exemplo, a homofobia e à alta incidência de violência contra as mulheres, incluindo a violência conjugal (Fávero, 2010).

Macedo (2013) corrobora essas ideias. Ela defende que muitas condutas violentas constituem respostas extremadas e inadequadas ao estresse e também são potencializadoras de estresse. Essas condutas formam, assim, um ciclo-vicioso e trazem muitas consequências físicas e emocionais deletérias a todas as pessoas envolvidas. Entendemos que essa tensão é gerada e naturalizada com base no grau de adesão de homens aos papéis de gênero ditos masculinos.

Lila et al. (2012) verificaram em seu estudo que homens com baixa autoestima tendem a naturalizar e justificar mais as agressões cometidas quando comparados a outros homens. Há um sofrimento e um preço a se pagar pela adesão a esses padrões de papéis masculinos. Os homens podem se esconder atrás desses papéis para tentar encobrir a insegurança, a autoestima baixa e sua 
fragilidade. A violência surge como uma possibilidade de demonstrar poder e virilidade, justamente quando sentem que estão mais desempoderados (Zuma et al., 2013). Baseados na ideia de Bourdieu, Zuma e colaboradores afirmam que:

os homens, sem se aperceberem, também são vítimas da própria dominação masculina. Assim, no fato de constantemente terem que atestar a sua virilidade, mesclada com a violência, os homens vivem a tensão e a contensão. E, nesse processo de testagem, aquilo que é tido como 'coragem' pode ser enraizado numa covardia, ou seja, pode se basear no medo 'viril' de ser excluído do mundo dos homens (p. 174).

A análise dos estudos sobre masculinidades e violência conjugal de Oliveira e Gomes (2011) apontou que os principais sentidos de homens relacionados ao ato agressivo foram a normalização, a minimização e as justificativas dadas para o uso da violência. Dohmen (2006; 2006a) e Nascimento et al. (2009) também incluem outros mecanismos que facilitam essa naturalização da violência:

- Negação;

- Minimização;

- Justificação;

- Externalização da culpa;

- Definições rígidas de masculinidade e feminilidade.

Nossa intenção nesse trabalho é considerar a importância de entendermos os sentidos da violência para os homens como uma forma de acessar os meios em que a violência foi naturalizada no processo de socialização e de construção de suas masculinidades. É relevante discutir como se dá a negação, minimização e a desresponsabilização - que inclui a justificação e a externalização da culpa na dinâmica conjugal. É nosso entendimento que esse processo pode abrir portas para desconstruir essa naturalização e possibilitar mudanças e transformações nessas relações.

\section{Negação e minimização}

Oliveira e Gomes (2011) argumentam que a socialização masculina favorece a negação e a minimização da violência. Lila et al. (2012) afirmam que a negação acontece quando a pessoa não percebe a violência, considera que tudo é uma mentira e que o processo corresponde a uma falsa denúncia. A minimização ocorre quando a pessoa banaliza ou diminui os efeitos das agressões, afirma que não é grave ou que não tem importância.

A polarização entre o público e privado contribui para a negação e a minimização da violência conjugal. Esse processo também tem suas raízes na socialização tradicional de gênero. Há uma desigualdade de valores entre a esfera pública, que é tida como a mais importante e atribuída ao masculino, e a esfera privada de menor valia e associada ao feminino. Nesse contexto, tudo o que 
acontece no âmbito doméstico tem menor importância, inclusive a violência (Maciel \& Barbosa, 2010; Silveira et al., 2009).

É muito comum entre participantes de grupos de homens autores de violência conjugal que eles compreendam as agressões cometidas por eles mesmos como qualitativamente diferentes e mais leves do que aquelas cometidas por outros homens que conheceram no acompanhamento. A maioria não reconhece ou minimiza a violência, nega que ela seja danosa às próprias parceiras, mas geralmente consegue identificar os prejuízos causados a outras mulheres (Chaves \& Silva, 2010; Ghesti-Galvão, Machado \& Costa, 2010; Moreira \& Matta, 2006; Rangel \& Tusi, 2010; Toneli et al., 2010).

No estudo realizado por Maciel e Barbosa (2010) com homens que passaram por acompanhamento psicossocial na Justiça em função de processos de violência conjugal, os participantes somente associaram a violência a eventos extremos, tais como guerra, assalto, terrorismo. Não perceberam e negaram várias formas abusivas de relacionamento no espaço privado como violência.

Esses participantes também minimizaram a violência por considerar desnecessária a busca da Justiça por parte da mulher. Eles não conseguiram reconhecer toda a magnitude da violência sofrida pelas companheiras e para si. Todos eles relataram ter sofrido alguma agressão de suas ex/parceiras, tais como xingamentos, ameaças e constrangimentos, mas também não consideraram importante a busca de ajuda. Eles apontaram como consequência mais grave da denúncia da mulher os prejuízos para o exercício do papel profissional, que é um dos pilares da identidade masculina em nosso contexto brasileiro e que é atribuído ao âmbito público.

Os participantes revelaram grande incômodo, resistência e revolta por terem que comparecer ao acompanhamento psicossocial. Eles apontaram como principal justificativa para tal incômodo a necessidade de faltar ao trabalho. Eles tiveram dificuldade para compreender como algo que aconteceu no espaço privado - a violência - teve consequências na esfera pública - o trabalho. Na perspectiva de muitos homens autores, fica a pergunta: "Como um acontecimento tão pequeno pode interferir em algo tão importante?” (Maciel \& Barbosa, 2010, p. 383).

Cabe ressaltar que muitos participantes perceberam a denúncia das mulheres como desejo e artifício de vingança contra eles e não como um meio para elas buscarem e receberem apoio e proteção. Vários estudos confirmam que a busca das mulheres pela Justiça geralmente é uma forma de colocar limite à violência e de buscar ajuda para o parceiro e para si, não é para prejudicá-los. A punição não corresponde à expectativa da maior parte dessas mulheres. Essa afirmação é corroborada por evidência - aproximadamente $70 \%$ delas não têm interesse em prosseguir com o processo judicial, especialmente quando a violência é interrompida e/ou fica na fase de lua de mel 
do ciclo da violência após a ocorrência policial (Maciel \& Barbosa, 2010; Ghesti, Roque \& Moura, 2006; Silva, 2012; Silveira et al., 2009).

Maciel e Barbosa (2010) verificaram também em que situação os homens buscam a Justiça. As questões públicas foram as mais citadas, tais como trabalho, indenizações etc. Essa pesquisa revelou que homens entendem ser muito humilhante a busca do sistema de justiça para lidar com dificuldades familiares ou conjugais, especialmente se for para denunciar alguma forma de violência praticada por uma mulher. Mesmo em situações em que ocorreram agressões graves, como foi o caso de um participante que supostamente levou uma facada, eles não buscaram a Justiça e revelaram sentir constrangimento em tornar pública a agressão sofrida. A justificativa recaiu em banalizar as agressões e em sempre tentar resolver sozinho. Na maioria dos casos, o recurso foi fazer justiça com as próprias mãos. Lamentavelmente, isso implica na reincidência de violências.

Esse estudo de Maciel e Barbosa (2010) revelou que mesmo com o despreparo do aparato policial e jurídico para acolher e lidar com as demandas masculinas, o processo de socialização teve peso na naturalização da violência por parte dos homens. Esse processo de naturalização e banalização exerce forte estímulo e legitima o uso da força física como forma de restaurar o poder na resolução dos conflitos. Nenhum participante mostrou interesse em buscar a lei ou terceiros para ajudar na superação da violência conjugal.

Alguns estudos sobre psicotraumatologia (Berceli, 2007, 2010; Besser, 2015; Levine \& Frederick, 1999; Macedo, 2013; Peichl \& Besser, 2014; Zampieri, 2009, 2011) ajudam a compreender os fenômenos de anestesias relacionais - inclusive a dissociação por meio da negação e minimização da violência. Nesse contexto as anestesias são entendidas como mecanismos de proteção da pessoa diante de um evento com potencial traumatogênico, não como uma patologia. Esses estudos confirmam que essas são estratégias de sobrevivência comuns diante desses eventos.

Levine e Frederick (1999) afirmam que a violência é um dos fatores que mais têm potencial de traumatizar as pessoas. A violência pode alterar a percepção de homens e mulheres envolvidos/as em relação a si próprios, ao outro e ao mundo. As anestesias constituem, portanto, uma estratégia de sobrevivência para tentar tornar o insuportável em algo tolerável. Geralmente as anestesias surgem quando as pessoas estão diante de fatores que ameaçam sua vida e/ou ultrapassam a sua possibilidade de lidar com a situação. Essas experiências vêm, na maioria das vezes, acompanhadas de sentimentos de desamparo e vulnerabilidade, especialmente se essas situações ou vivências forem duradouras e intensas, como acontece em muitos casos de violência conjugal. 
O recurso às anestesias é uma reação natural do organismo das pessoas diante de situações disruptivas - que têm o potencial de ser traumatogênicas. É uma forma de lutar, fugir e/ou dissociar. $\mathrm{O}$ cérebro possui mecanismos para proteger a pessoa de reações emocionais que ameaçam a sua integridade física, emocional e relacional. Esses mecanismos geram a possibilidade delas passarem por períodos críticos e ameaçadores, pois eles alteram a memória e as sensações da pessoa por meio da dissociação e da negação até que, posteriormente, ela esteja em local e momento seguro para que esses estados alterados possam desaparecer gradual e naturalmente (Levine \& Frederick, 1999; Zampieri, 2011).

Mecanismos protetores são ativados para proteger a pessoa da "dor da morte" (Levine \& Frederick, 1999, p. 123). A dissociação distorce a noção de tempo e de percepção em experiências que ameaçam a integridade ou a vida da pessoa. A dissociação se torna crônica quando as pessoas são repetidamente traumatizadas. As pessoas não têm consciência dessa dissociação, o que impede ou dificulta que elas possam superar os sintomas do trauma. Os devaneios e o esquecimento são os possíveis sintomas mais comuns da dissociação.

A negação, comum nos processos de anestesia, é outra forma de dissociação. Ela ocorre quando há uma desconexão completa entre o/s acontecimento/s, a memória e os sentimentos da pessoa, que pode negar que um fato aconteceu ou pode agir como se ele não tivesse importância. A negação ocorre como meio de evitar o reconhecimento dessas emoções, pois entrar em contato com eles poderia ser doloroso demais.

Nessas experiências, o cérebro pode funcionar de forma diferente daquela que ocorre em

outras vivências comuns. É como se fosse um estado de exceção. O problema surge quando essa exceção se transforma em regra diante da permanência e perpetuação da situação disruptiva. Assim, a negação pode vir a ser cronificada e comprometer a saúde mental das pessoas (Berceli, 2010; Levine \& Frederick, 1999).

Estudos da psicotraumatologia são importantes para corroborar a nível fisiológico a ocorrência das anestesias - não como causas, mas como consequências da violência. As pessoas traumatizadas podem ter as funções de seu neocórtex comprometidas, pois o sistema límbico (responsável pelas emoções) e o tronco cerebral (parte mais primitiva do cérebro - responsável principalmente pelas funções básicas e autônomas do organismo) são superestimulados para garantir a sobrevivência da pessoa. Assim, é importante ajudar a pessoa na integração de sentimentos - de modo que a negação dê lugar ao medo, à raiva, à tristeza ou à vergonha (Berceli, 2010; Levine \& Frederick, 1999; Macedo, 2013; Zampieri, 2011).

Os estudos recentes dessa área mostram que o conceito de neuroplasticidade é útil para mostrar que as experiências das pessoas podem alterar as funções do cérebro e influenciar no 
desenvolvimento de suas habilidades cognitivas, emocionais, físicas, sociais e culturais, inclusive, de sua subjetividade. O cérebro humano pode ter suas funções modificadas de acordo com aspectos sociais, experiências de afeto, reações emocionais e fisiológicas. As experiências com potencial traumatogênico podem influenciar, especialmente, no modo que elas percebem as coisas e suas relações (Berceli, 2007, 2010; Besser, 2015; Levine \& Frederick, 1999). Essas constatações estão de acordo com o conceito de anestesia relacional discutido por Ravazzola (1997).

Esse breve resumo mostra que pesquisas da psicotraumatologia reforçam a importância dos estudos sobre as questões de gênero ao enfatizar a complexidade do fenômeno das anestesias e a influência de aspectos sociais na naturalização da violência. O fato é que além do processo de negação e de minimização, a desresponsabilização é outro meio de naturalização da violência e será problematizado a seguir.

\section{Desresponsabilização: justificação e externalização da violência}

A desresponsabilização pela violência é outro fenômeno muito frequente de naturalização das agressões. A justificação e a externalização da violência são as suas principais características e são utilizadas para explicar a ocorrência da violência conjugal, geralmente baseada nos padrões da masculinidade hegemônica. Os motivos para o uso da violência contra suas ex/companheiras geralmente são entendidos pelos homens como estratégias de defesa, como comunicação inadequada da frustração quanto ao relacionamento e quanto ao que eles consideram comportamentos inadequados diante do papel socialmente atribuído ao feminino (Alves \& Diniz, 2005; Araújo, 2012; Lila et al., 2012; Macedo, 2013; Ramos, 2013; Separavich \& Canesqui, 2013; Siqueira, 2012).

Oliveira e Gomes (2011) realizaram estudo no contexto brasileiro e apontaram os principais sentidos dos atos violentos para homens em geral e para homens autores de violência de modo específico. Os primeiros geralmente consideraram a violência como algo condenável, contudo tolerável como forma de revide e como estratégia para disciplinar a "mulher que gosta de apanhar". Para os homens autores de violência, a violência aparece como algo normal e justificável como medida "educativa" ou "corretiva" para o bem das parceiras ou como algo visto como próprio do modo de ser dos homens.

O trabalho de Silveira et al. (2009) corrobora essa ideia. Os autores identificaram duas categorias analíticas de justificativas usadas como meio de desresponsabilização dos homens em situação de violência conjugal. A primeira categoria de justificativas recai na culpabilização da mulher pelas mudanças no relacionamento conjugal, uma vez que tais mudanças desestabilizam os padrões hegemônicos de gênero e instalam os conflitos. Os homens culpabilizaram as mulheres pelas mudanças nesses padrões, quando consideraram que elas mudam de comportamento, quando 
ficam ou são agressivas, infiéis, provocativas ou não cumprem com as atribuições imputadas socialmente a elas, tais como as responsabilidades domésticas e com o cuidado da família. Nessas situações geradoras de conflito ou violência, eles se colocaram como apaziguadores ou reativos às agressões delas. Associaram a "perda de controle" às mudanças das mulheres.

O segundo padrão de justificação ocorre no contexto em que a violência é o sentido da relação conjugal, ou seja, ela compõe o padrão relacional. Essa forma de perceber e justificar a presença da violência eleva as dificuldades por parte dos homens em reconhecerem a violência, pois ela constitui a conjugalidade, faz parte da estrutura da dinâmica relacional e tende a se repetir indefinidamente. A violência seria uma forma de realocar homens e mulheres em seus papéis definidos socialmente pelos padrões hegemônicos de gênero. A denúncia das mulheres seria uma das poucas formas de tentar romper esse padrão. Nesse contexto relacional, como a violência se configura como um elo, os homens não percebem essa denúncia como um pedido de ajuda, mas como uma verdadeira traição, e por isso muitas vezes a recebem com muito sofrimento e decepção. No entanto, essa denúncia tem o potencial de reconfigurar a relação a partir da intervenção da justiça e de terceiros (Silveira et al., 2009).

Silveira e colaboradores (2009) ressaltaram que essas duas categorias não são excludentes e nem estanques, uma vez que em alguns momentos apresentam correlações e tensões entre elas (Silveira et al., 2009). Outras justificativas frequentemente utilizadas pelos homens dizem respeito a qualquer ameaça à sua masculinidade, sua heterossexualidade e/ou ao seu poder (Toneli et al., 2010). Muitos homens compreendem que devem reafirmar sua masculinidade através do jogo relacional e de cobranças subjetivas, assim como pelo controle social e da sexualidade da mulher (Teixeira, 2009). O controle e o ciúme não são compreendidos como forma de coagir ou de exercer um tipo de violência, mas como meios naturais e constituintes de "parte dos atributos e direitos dos homens sobre as mulheres no contexto de uma relação conjugal" (Silveira et al., 2009, p. 958).

Oliveira e Gomes (2011) resumiram os resultados de estudos brasileiros sobre as principais justificativas utilizadas pelos homens autores para cometerem atos de violência conjugal:

- Ciúme;

- Infidelidade;

- Desemprego ou dificuldade financeira do homem;

- Dependência química;

- Agressão física ou psicológica da companheira;

- Outros "erros" dela (cobrança e falta de compreensão, recusa sexual, confrontação, domínio sobre o companheiro e destituição da palavra dele, desonestidade, desobediência e dedicação ao emprego dela); 
- Discussões sobre criação de filhos e as finanças da casa;

- Divergências quanto aos papéis de homem e de mulher;

- Dificuldade de dialogar;

- Medo de perder o controle sobre a mulher.

O fato é que tudo pode servir como motivo para a violência conjugal em uma sociedade machista. Separavich e Canesqui (2013) afirmam que essa longa lista de justificação revela a relação assimétrica estabelecida na conjugalidade, que têm o homem como provedor e no papel de dominação e a mulher como subordinada.

Um exemplo comum dessa assimetria está relacionado ao direito do homem à infidelidade. A traição se configura como uma prática masculina na dinâmica conjugal. Ela representa um mecanismo de afirmação da masculinidade para os homens sobre as mulheres, que fortalece a desigualdade de gênero e justifica a instalação da violência conjugal. A descoberta da infidelidade geralmente é a porta de entrada para o surgimento de conflitos, e, consequentemente, de outras agressões (Souzas \& Alvarenga, 2001).

Diversos autores (Buompadre, 2013; Manzanares \& Salgado, 2013; Souzas \& Alvarenga, 2001) correlacionam a violência conjugal e infidelidade, pelo fato de os dois fenômenos terem em comum vários fatores multicausais, dentre eles, as concepções estereotipadas de gênero. A infidelidade é valorizada para os homens e não é permitida para as mulheres. A traição favorece o surgimento de conflitos. Muitos cônjuges não têm condições de resolver esses conflitos de maneira efetiva, processo que acaba desencadeando a instalação da violência.

A justificação com base em papéis e padrões hegemônicos de gênero potencializa, inclusive, a recusa de muitos homens em pedir ajuda, especialmente a policial ou a jurídica. Na pesquisa de Maciel e Barbosa (2010) a maior parte dos homens consideraram desnecessária a ajuda da Justiça eles banalizaram e minimizaram a gravidade dos fatos. Para eles, entrar numa delegacia é motivo de vergonha e de insegurança mesmo quando eles são vítimas de violência. Nessa situação, eles podem estar sujeitos a ouvir adjetivações por parte dos pares ou dos profissionais, que atingem diretamente sua identidade masculina. Muitos homens relataram escutar nas delegacias termos como: frouxo, maricas, bunda-mole. Um participante ouviu o seguinte questionamento de um policial: "Como que você, homem da casa, deixa uma mulher te bater?” (p. 379).

Essa justificação em não buscar ajuda tem como base os aspectos relacionados à socialização masculina e o despreparo dos policiais, que também reproduzem e cobram os valores e papéis estereotipados de gênero. Ao serem questionados na pesquisa de Maciel e Barbosa (2010) caso existisse uma delegacia de atendimento ao homem, todos participantes afirmaram que não buscariam o serviço. A recusa foi unânime. 
A externalização da culpa é outra forma de desresponsabilização e acontece quando se atribui a responsabilidade pela violência a fatores externos e a terceiros. Geralmente, os homens tendem a atribuir a responsabilidade pela ocorrência de violências à mulher, aos amigos, à família, aos eventos disparadores externos - álcool, problemas no trabalho, dificuldades financeiras etc. (Dohmen, 2006, 2006a; Grossi, 1995). Manita (2008) afirma que a violência é um comportamento deliberado, intencional e uma busca para controlar o outro. Essa externalização não pode ser entendida como fruto de determinação biológica ou psicopatológica, mesmo em casos de coocorrência de alcoolismo, toxicodepêndência ou psicopatologias menos severas.

A justificativa da violência pelo abuso ou dependência de álcool é tão comum que muitos profissionais e pesquisadores confundem a relação entre esses dois fenômenos. Beiras et al. (2012) reforçam a importância de não atribuir causalidade entre violência e álcool/drogas, apesar de sua estreita relação. Muitos homens não a cometem após ingerirem essas substâncias, bem como muitos a fazem estando ou não sob seus efeitos. O álcool e outras drogas são conhecidos como fatores potencializadores, mas não são necessariamente fatores causais da violência. Eles são usados como justificativas pelos homens, em uma forma de autodesculpabilização, racionalização ou neutralização da violência (Aguiar, 2009; Manita, 2008; Schmidt, 2010).

A idealização da relação é outra forma muito comum para homens autores de violência justificarem a violência e culpabilizarem as mulheres. Ao idealizarem o relacionamento, trazem narrativas sobre a importância do respeito, do diálogo e da compreensão. Esses aspectos idealizados podem ter dois significados: justificação da violência ou possibilidade de flexibilização da adesão aos papéis de gênero.

A idealização pode servir como justificativa para reafirmar os padrões hegemônicos de gênero. Esse processo pode servir de base para o controle da mulher, especialmente quando os papéis de gênero são desestabilizados na relação. Geralmente, os homens entendem que cabe à mulher mudar o seu comportamento e, quando isso não ocorre, a violência pode se re/instalar na relação (Silveira et al., 2009).

Tal idealização também pode compor um cenário que indique uma possibilidade de flexibilização de gênero. Essa idealização sugere que pode haver uma "abertura por parte de alguns homens quanto a outras maneiras de se relacionar. Nesse contexto, é de fundamental importância a promoção de reflexão e a reinvenção das relações de gênero e, consequentemente, de outras formas de relações conjugais" (Silveira et al., 2009, p. 963).

A responsabilização de homens pela violência é possível, mas exige muitos esforços para romper com todos os aspectos arraigados e introjetados pela socialização de gênero. Muitos homens que participam de acompanhamento psicossocial permanecem alienados e não se responsabilizam. 
Outros conseguem iniciar o processo de responsabilização e reconhecer as dificuldades que trazem consigo, mas apresentam dificuldades em conseguir mudanças significativas. É comum alguns homens conseguirem cessar as agressões físicas, mas permanecerem com outras formas sutis de violência. Outros conseguem engajar nesse processo de mudanças e transformações e superar a violência (Aguiar, 2009; Araújo, 2012; Figueira, 2011; Macedo, 2013; Lila et al., 2012; Oliveira \& Gomes, 2011; Silveira et al., 2009).

Cabe ressaltar que muitos homens são capazes de perceber a complementaridade da naturalização da violência por parte de suas parceiras. Vários deles sentiram a necessidade de as parceiras também participarem das intervenções para garantir o sucesso do acompanhamento psicossocial. Essa demanda foi além da necessidade de superar a naturalização. $O$ fato é que alguns homens "por se sentirem acolhidos no próprio sofrimento, manifestaram o desejo de que suas companheiras também pudessem usufruir o mesmo processo" (Acosta et al., 2004, p. 34).

\section{Complementaridade da naturalização}

Um homem ao negar, minimizar e se desresponsabilizar pela violência contra a ex/parceira tem o aval de todo um contexto social que reforça sua fala e naturaliza a instalação e manutenção da conjugalidade marcada pela violência. A manutenção da socialização tradicional de gênero recebe grande influência de pares, da família e da sociedade tanto para os homens, quanto para as mulheres. Muitas mulheres ainda são socializadas para terem papel complementar à agressividade masculina, pois são encorajadas a culpabilizarem a si mesmas e acabam naturalizando a violência, inclusive a física e/ou sexual (Nascimento et al., 2009).

A naturalização da violência também pode ser realizada pelas mulheres. Vale ressaltar, que é importante não responsabilizar ou culpabilizar a mulher vítima pela violência sofrida, pois elas podem querer o fim da violência, mas podem não querer ou não estarem preparadas para saírem da relação ou abandonarem o cônjuge (Manita, 2008). Fávero (2010) afirma que pode acontecer o fenômeno do "laço duplo" nesses casos, em que aderindo ou não ao papel feminino tradicional ela é criticada e rejeitada socialmente e pode ser advertida sobre o risco de ser infeliz se aderir e de não ser "feminina" se não aderir. Cabe apontar que em contextos de pobreza e de vulnerabilidade social, a manutenção da relação pode adquirir valor de sobrevivência em muitos casos.

Estudo de Guimarães (2009) revelou a tendência de muitas mulheres em negar, minimizar e/ou justificar a violência. Essa tendência resultou em cinco categorias: 1. medo das consequências da separação; 2. expectativa de mudança do parceiro/relação; 3. ambiguidade/minimização de sentimentos; 4. culpabilização da mulher; 5. desresponsabilização do homem autor. Esses fatores contribuem para que muitas mulheres não percebam o impacto da violência em suas vidas e fiquem cada vez mais anestesiadas. 
A minimização da violência pode acontecer com as mulheres, especialmente quando elas começam a reagir às agressões sofridas. Essa dinâmica oferece perigos adicionais, pois tem o potencial de desencadear mais agressão masculina contra a parceira. Essa violência costuma ser amparada nas teses de autodefesa feminina, que tende a ser aceita socialmente e, raramente, é denunciada pelos homens, pois esses ficam aprisionados ao ideário da honra e do sentimento de vergonha em buscar ajuda (Alves et al., 2012).

No contexto em que as mulheres também agridem/revidam a violência, aumenta o risco da escalada da violência e diminui a chance de uma ajuda efetiva, pois muitos profissionais também minimizam e aceitam a violência feminina. Temos que nos atentar para o fato que os homens e as mulheres podem atuar como autores e vítimas e ambos podem justificar a violência mútua (Alves et al., 2012). Oliveira \& Gomes (2011) afirmam que tanto a falta de responsabilização dos homens em relação às agressões e as justificativas e queixas das mulheres vítimas atuam em prol da manutenção da violência.

A naturalização da violência é uma questão extremamente complexa e favorece essa perpetuação das agressões. Tentamos construir uma síntese de modo a apontar suas várias dimensões. Fica evidente que elas vão muito além do indivíduo. Concordamos com Medrado e Lyra (2008) quando ressaltam a necessidade e a potencialidade dos estudos sobre homens e masculinidades abrirem portas para novas construções teóricas que agreguem os aspectos plural, polissêmico e crítico das leituras de gênero e feministas para entendermos e repensarmos esses processos de naturalização da violência.

Verificamos que as anestesias se instalam e se revelam na conjugalidade por meio do processo social de naturalização da violência. Simultaneamente, as anestesias relacionais reforçam essa naturalização da violência no âmbito da conjugalidade. As anestesias se revelam na relação por meio dos processos de negação, minimização e desresponsabilização de homens e mulheres descritos acima. As anestesias dificultam a percepção da dimensão real da violência e compromete a reflexão sobre seus impactos. Elas podem favorecer o aprisionamento de ambos a um padrão relacional paradoxal e com grande investimento afetivo (Angelim, 2009; Angelim \& Diniz, 2010). Esse processo de naturalização da violência contribui também para a instalação de uma dinâmica duplo-vincular. A Teoria do Duplo-Vínculo pode complementar os avanços trazidos por Ravazzola (1997, 1998) e ampliar a compreensão de diversos aspectos que agravam e perpetuam a dinâmica relacional marcada pela violência.

\section{Teoria do duplo-vínculo e o aprisionamento de homens e mulheres à relação}

A aplicação da Teoria do Duplo-Vínculo - TDV ao contexto da violência conjugal pode ser um importante instrumento de compreensão e intervenção com homens autores de violência. 
Apresentamos um breve contexto histórico e as principais características dessa teoria, para então tratar das condições de sua aplicação aos relacionamentos conjugais. Consideramos importante a reflexão sobre a inclusão da TDV como uma ferramenta a mais para pensar e lidar com situações de violência conjugal.

\section{Teoria do Duplo-Vínculo: breve contextualização}

A Teoria do Duplo-Vínculo ou Teoria da Dupla-Vinculação foi apresentada pela primeira vez em 1956, por Gregory Bateson, Don Jackson, Jay Haley e John Weakland no artigo “Toward a Theory of Schizophrenia" ("Rumo a uma teoria da esquizofrenia"). Esses autores constituíam o grupo de pesquisa que fundou o Mental Research Institute - MRI em Palo Alto, Califórnia - EUA, o qual se tornou um dos berços fundamentais de construção de aportes teóricos para a terapia conjugal e familiar de base sistêmica. Eles ficaram conhecidos como Grupo de Palo Alto (Cronen, Johnson \& Lannamann, 1982; Mahmoud, 2003; Watzlawick et al., 1967/2007).

O Grupo de Palo Alto discutiu o papel da linguagem como processo importante na estruturação da personalidade das pessoas. Eles lançaram, então, as primeiras ideias sobre a presença de dinâmica duplo-vincular nos relacionamentos familiares. Descreveram padrões de comunicação complexos e com potencial de desenvolver diversas psicopatologias. As pessoas envolvidas nessas relações familiares podiam apresentar sentimentos de ansiedade, dúvidas sobre suas percepções e psicopatologias (Mahmoud, 2003; Watzlawick et al., 1967/2007).

A TDV tornou-se uma nova forma de olhar, entender e intervir na etiologia e manutenção de diversas psicopatologias. Essa teoria se consolidou com forte aporte teórico e de pesquisas na área de saúde mental. Ela teve ampla aceitação na ciência e na política desde a sua formulação. O Grupo de Palo Alto ganhou diversos prêmios pela repercussão e impacto da TDV (Angelim, 2009; Watzlawick et al., 1967/2007).

Os primeiros estudos foram direcionados às famílias com pacientes diagnosticados com esquizofrenia. Depois a TDV foi aplicada a várias outras áreas da saúde mental. Terapeutas familiares passaram a investigar e intervir nos padrões de relacionamento ao invés de buscar uma experiência traumática específica como origem dos transtornos psicopatológicos, pois saíram de uma visão simplista e linear para uma compreensão sistêmica das relações familiares e da saúde mental de seus membros (Angelim, 2009; Angelim \& Diniz, 2010; Diniz \& Angelim, 2003; McGoldrick, 2003; Nichols \& Schwartz, 2007; Vazquez, 2014).

O grupo do MRI estudou os efeitos dos paradoxos na comunicação e nas relações humanas para postular a TDV. Liderados pelo biólogo e antropólogo Gregory Bateson, eles identificaram determinadas características essenciais da interação paradoxal e criaram o termo duplo-vínculo para estudar a Teoria da Comunicação (Watzlawick et al., 1967/2007; Zordan, Dellatorre \& Wieczorek, 
2012). Essa teoria foi importante para desenvolver uma noção sistêmica entre a patologia comunicacional e a gênese de da esquizofrenia.

O grupo do MRI propôs cinco axiomas básicos da Teoria da Comunicação (Watzlawick et al., 1967/2007; Zordan et al., 2012):

- $1^{\circ}$ Axioma: Todo comportamento é comunicação e toda comunicação é comportamento. Como o comportamento não tem oposto, não existe um não-comportamento. Dessa forma, não existe uma não-comunicação, sendo impossível não se comunicar;

- $2^{\circ}$ Axioma: Toda comunicação tem dois aspectos relacionados, um de conteúdo e outro de relação. Esse aspecto relacional é conhecido como metacomunicação e classifica o conteúdo. Assim, uma comunicação não transmite apenas um conteúdo, ela impõe, simultaneamente, um comportamento;

- $3^{\circ}$ Axioma: A comunicação é composta pela pontuação da sequência de eventos, que acontece de forma ininterrupta. As pessoas não conseguem perceber toda a ordem e a sequência causal durante a troca de mensagens. Nessa interação, cada indivíduo apreende o mundo de sua maneira. A divergência sobre a forma de compreender e organizar a sequência de eventos é a base de muitos conflitos relacionais;

- $4^{\circ}$ Axioma: Existem duas formas de comunicação humana - a digital e a analógica. A primeira se refere à comunicação verbal. A segunda abrange as outras formas de expressão;

- $5^{\circ}$ Axioma: As interações comunicacionais possuem característica de simetria e de complementaridade. As relações se baseiam nas dimensões de igualdade e diferenças entre as pessoas, respectivamente. No primeiro caso, os indivíduos refletem o comportamento um do outro, caracterizada pela igualdade e pela minimização da diferença. No segundo, o comportamento de um complementa o do outro, baseando-se na maximização da diferença (Watzlawick et al., 1967/2007; Zordan, Dellatorre \& Wieczorek, 2012).

Influenciados pela Teoria da Comunicação, Watzlawick, Beavin e Jackson (1967/2007) desenvolveram vários estudos sobre a Pragmática da Comunicação Humana - PCH. Apesar de ser muito estudada desde a década de 1960, a PCH ainda é uma ciência muito recente e está em sua infância. A PCH busca a integração com outros campos de atividade científica para o seu desenvolvimento, pois extrapola os limites de qualquer disciplina isolada (Watzlawick et al., 1967/2007; Zordan et al., 2012).

A PCH tem interesse nos efeitos comportamentais da comunicação, especialmente a partir da natureza do paradoxo. Esses pesquisadores verificaram que a comunicação paradoxal tem 
importância pragmática e até existencial para a nossa espécie, pois pode afetar a interação, o comportamento e a sanidade mental dos indivíduos. Os paradoxos fascinam os seres humanos desde os últimos dois mil anos até hoje (Watzlawick et al., 1967/2007).

O paradoxo foi definido pelo Grupo do MRI como "uma contradição que resulta de uma dedução correta a partir de premissas coerentes" (Watzlawick et al., 1967/2007, p. 169). Watzlawick et al. afirmam que a própria definição de paradoxo é confusa, pois a sua divisão em aspectos reais e falsos é relativa. As premissas coerentes atualmente talvez sejam falácias ou erros no futuro. Os paradoxos podem ser divididos em três tipos:

- Lógico-matemáticos;

- Definições paradoxais (antonímias semânticas);

- Paradoxos pragmáticos.

A PCH tem interesse pelos paradoxos pragmáticos, pois são muito frequentes no cotidiano das pessoas e têm importância prática para a saúde mental dos indivíduos, das famílias, das sociedades e das nações. A PCH apresentou a complexidade da comunicação paradoxal nas relações conjugais e familiares. Essa comunicação "gera uma situação insustentável. Como a mensagem é paradoxal, qualquer reação a ela, dentro do quadro estabelecido pela mensagem, terá de ser igualmente paradoxal. É simplesmente impossível um comportamento coerente e lógico num contexto incoerente e ilógico" (Watzlawick et al., 1967/2007, p. 177).

A metacomunicação ganha destaque nas comunicações paradoxais. Ela é definida como a comunicação sobre a comunicação. A metacomunicação também é complexa, pois é difícil identificar todos os elementos comunicacionais que vão além da fala. A solução fica mais difícil quando a comunicação em diferentes níveis é contraditória e/ou revestida por uma autoridade para o receptor da comunicação (Watzlawick et al., 1967/2007).

Há uma diferenciação e hierarquia entre os conceitos: contradição, paradoxo e duplovínculo. Uma simples contradição pode ser rejeitada sem maiores complicações. As contradições geralmente são cotidianas e não são patogênicas. A escolha é possível para o indivíduo. Quando as pessoas estão diante de uma contradição, elas podem escolher por uma ou outra opção. Mesmo quando tem consequências negativas, pode-se perder algo ou sofrer alguma punição, mas ainda pode haver escolhas (Watzlawick et al., 1967/2007).

O paradoxo é literalmente a falência da própria escolha. Não existe possibilidade de escolher entre uma alternativa correta. Todas as opções fazem parte de um contexto de perda ou sofrimento: “perde se a toma e perde se não a toma". É difícil perceber a ausência de escolhas e reconhecer a falta de alternativas (Watzlawick et al., 1967/2007). 
Os duplo-vínculos são muito mais complexos que simples contradições e abrange verdadeiros paradoxos. Outras condições são exigidas além das mensagens paradoxais para configurar um duplo-vínculo (Watzlawick et al., 1967/2007). Influenciados pelo trabalho do grupo de Bateson, Watzlawick et al. (1967/2007) começaram a perceber algumas dinâmicas comuns em diversas famílias com pacientes esquizofrênicos em suas pesquisas. Essas características foram consideradas as condições de duplo-vínculo. Esses autores perceberam que determinadas condições relacionais configuravam experiências constantes, que precisavam ser vivenciadas diversas vezes para desencadear um transtorno (Angelim, 2009; Mahmoud, 2003).

Watzlawick et al. (1967/2007) ampliaram a TDV e descreveram cinco critérios específicos para avaliar se uma relação poderia ser considerada como duplo-vincular:

1. Presença de duas ou mais pessoas em uma relação intensa, de elevado grau de expectativa ou valor de sobrevivência física e/ou psicológica;

2. Prevalência de mensagens paradoxais, em que a pessoa afirma algo e comunica algo contraditório sobre a própria afirmação. Por exemplo, o cônjuge pode alegar "você pode sair com suas amigas" e brigar pelo fato da mulher estar se arrumando para sair com as amigas. Ou seja, as duas mensagens excluem-se mutuamente e são realizadas em níveis comunicacionais diferentes;

3. O/a receptor/a da mensagem fica impedido/a de refletir e de sair do padrão interacional ou do contexto;

4. Quando o padrão de DV é duradouro ou crônico, transforma-se em expectativa autônoma e não exige reforço posterior para sua perpetuação; e

5. O comportamento paradoxal conferido pela dupla-vinculação é, por sua vez, um duplovínculo e isto redunda em um ciclo vicioso no padrão comunicacional que perpetua a si mesmo (Watzlawick et al., 1967/2007).

Essas relações incluem, mas não se limitam a vida familiar. O duplo-vínculo vai muito além do que simples contradições ou paradoxos e exige a integração dos cinco elementos acima. Para enfatizar a complexidade do duplo-vínculo, Watzlawick et al. (1967/2007) afirmam que:

Embora a mensagem seja destituída de significação lógica, ela constitui uma realidade pragmática (...) uma pessoa numa situação de dupla vinculação é passível, portanto, de se ver punida (ou, pelo menos, de ser levada a sentir-se culpada) pelas suas percepções corretas e definida como "má" ou "louca" se insinuar sequer que existe uma discrepância entre o que vê, de fato, e o que "devia" ver. Esta é a essência do duplo vínculo (Watzlawick et al., 1967/2007, p. 192).

Mahmoud (2003) corrobora essa definição e entende um relacionamento permeado pelo duplo-vínculo quando uma pessoa mais poderosa vitimiza uma pessoa menos poderosa ao 
comunicar de maneira mistificadora. Essa comunicação vincula o/a receptor/a, deixando sem espaço para refletir, se sentir seguro/a ou buscar ajuda.

A mistificação ocorre por meio de mensagens sutis e dissimuladas, que contradizem as mensagens mais explícitas. A pessoa fica sem capacidade de falar sobre essa discrepância e de se libertar da relação. O duplo-vínculo é mais poderoso e intenso quando ocorre nas relações familiares (Mahmoud, 2003). Norman (2011) afirma que essas mensagens paradoxais impõem diretivas contraditórias que colocam todos/as envolvidos/as em uma difícil ou impossível posição.

As consequências da dinâmica duplo-vincular são inúmeras. Watzlawick et al. (1967/2007) apresentaram algumas alternativas mais comuns, mas que não são únicas. Geralmente, a pessoa nessa situação obedece a qualquer e toda ordem e fica sem capacidade de expor algum pensamento independente. Ela pode renunciar o contato com outras pessoas, favorecendo o isolamento social. Norman (2011) afirma que frequentemente homens e mulheres em dinâmicas de duplo-vínculos culminam em explosões de ansiedade, medo e até distorção de autoimagem. Mahmoud (2003) acrescenta que essas pessoas apresentam diversos sintomas do Transtorno de Estresse PósTraumático - TEPT, especialmente a hipervigilância.

Há um alto risco ao enfrentar e tentar quebrar a relação duplo-vincular. As consequências podem ser ainda mais dolorosas que a própria dinâmica. As percepções da pessoa podem ser desqualificadas, não só na relação, mas também por profissionais que não compreendem esse fenômeno. Diante da desigualdade na relação, há uma tendência da pessoa aceitar passivamente e repremir os sentimentos, o que traz consequências ainda mais graves para a sua saúde mental (Mahmoud, 2003). É muito comum os/as indivíduos/as escutarem os seguintes relatos ao tentar superar esse padrão:

- "Isso é loucura";

- "Deve haver algo errado com você por perceber a situação dessa maneira";

- "Isso não tem base na realidade";

- "Você é sensível demais";

- "Está alimentando a discórdia e o conflito onde nada existiu antes, e por isso terei que puni-lo" (Mahmoud, 2003).

Enfrentar a relação duplo-vincular no contexto conjugal ou familiar pode ter um custo muito mais alto (Mahmoud, 2003). Essa autora afirma que "uma coisa é correr o risco de uma punição, receber essa punição e estar livre para deixar o 'campo do conflito'; outra coisa é ter que retornar a ele todos os dias" (p. 297). Por isso, esses padrões são mais intensos em relações familiares. Esses sintomas consomem grande parte da energia psíquica dessas pessoas. As consequências se 
potencializam com o tempo. Quanto maior o período de exposição ao relacionamento duplovincular, mais severo e intenso são os danos emocionais (Mahmoud, 2003).

O duplo-vínculo é tão intenso e devastador que existem poucas maneiras de superá-lo. Escapar fisicamente do campo de conflito é uma das raras opções efetivas de romper com esse padrão. Afastar do local pode trazer alívio significativo, mas geralmente não é suficiente para garantir a superação psicológica ou emocional, pois muitas vezes permanecem as cicatrizes do conflito, as lembranças traumáticas, a depressão e a raiva (Mahmoud, 2003).

Uma segunda opção para superar o padrão é conseguir tomar a decisão de correr o risco da punição por meio do confronto direto. Geralmente as pessoas recorrem a esse recurso quando não aguentam mais a situação. Entretanto, esse confronto é pouco efetivo e traz grande risco de intensificar a opressão (Mahmoud, 2003).

A terceira forma de superá-lo é recorrer a familiares, amigos ou instituições. A comprovação da percepção por parte de outra pessoa pode ser bem efetiva. Terceiros podem atuar como caixas de ressonância para confirmar as suas percepções: "ele realmente disse o que eu achei que ele disse? Estou sendo sensível demais?” (Mahmoud, 2003, p. 302). Essa autora afirma que profissionais podem ser importantes ratificadores dessas experiências, mas precisam compreender o fenômeno do duplo-vínculo para poder ajudar efetivamente.

Watzlawick et al. (1967/2007) dão suporte a essas ideias, pois afirmam que os/as profissionais podem intervir de modo a romper esse padrão. No entanto, a intervenção deve transcender os conselhos, que nesses casos são ineficazes. Os/as profissionais podem usar vários instrumentos como compreensão, sinceridade, calor, firmeza, compaixão, que são necessários, mas não suficientes para lidar com as complexidades da relação. Algumas intervenções paradoxais podem atuar como dupla-vinculações terapêuticas. Os fatores que favorecem o sofrimento ou o adoecimento, geralmente também podem ser úteis para superar o padrão relacional. Watzlawick et al. enfatizam que no duplo-vínculo patogênico, sofre se o faz e sofre se não o faz. Já no duplovínculo terapêutico, a pessoa muda se o faz e muda se não o faz.

Mahmoud (2003) descreve algumas técnicas para ajudar pessoas em dinâmicas de duplovínculo. Ela afirma que oferecer apoio, lugar seguro para exposição de sentimentos, até medicação contra ansiedade e/ou encaminhamento para grupo de apoio são necessários, mas muitas vezes são insuficientes se não lidar diretamente com a opressão e com os critérios de duplo-vínculo. Os/as profissionais não podem ignorar, de forma alguma, que a dinâmica é fundamental na vida de pessoa e nem subestimar as suas consequências. A intervenção não pode minimizar o sofrimento da pessoa ou justificar a opressão permeada pelo duplo-vínculo. 
Uma técnica eficiente consiste em explorar ativamente e diagramar os padrões de comunicação da relação. Para isso, são necessárias várias sessões para analisar todas as camadas de sentimentos desencadeados. É preciso ouvir, entender, tranquilizar e validar as percepções próprias da pessoa. A validação pelo profissional da experiência vivenciada pelo/a indivíduo/a é fundamental, pois outras pessoas têm força de confirmação dessas percepções, comumente negadas no íntimo da relação (Angelim \& Diniz, 2010; Mahmoud, 2003).

É fundamental evitar o envio de mensagens contraditórias e a neutralidade, pois essas posturas podem provocar mais ansiedade. É importante acreditar na pessoa, pois a desconfiança pode causar novos traumas e evitar que se busque ajuda novamente. Ou seja, além de revitimizar, pode fechar as portas para a pessoa recorrer a terceiros novamente em caso de reincidência. Muitos/as profissionais bem intencionados/as podem criar ou aprofundar ainda mais a dinâmica duplo-vincular, principalmente se negarem a experiência da pessoa ou se não lidar diretamente com a fonte de sofrimento dela (Angelim \& Diniz, 2010; Mahmoud, 2003).

Knickmeyer, Levitt, Horne e Bayer (2003) realizaram um estudo que identificou os duplovínculos gerados pela rede de apoio de mulheres vítimas de violência, especialmente de líderes religiosos, familiares e conhecidos. Muitas pessoas em situação de violência eram simultaneamente encorajadas pela rede a deixar e a ficar na relação. As mensagens paradoxais para permanecer e sair da conjugalidade formaram duplo-vínculos que aumentavam a dificuldade de tomar decisões e eram efetivas em perpetuar a violência.

A vinculação é outra variável imprescindível para promover a confiança e proporcionar os primeiros passos rumo ao empoderamento. Esse empoderamento pode ser favorecido quando se explica como se dá o processo de duplo-vínculo para a pessoa. Nesse caso, é importante ajudá-la a observar e reconhecer os principais aspectos da dinâmica que lhe aprisionam (Mahmoud, 2003). Especialmente as quatro características a seguir:

- Frequência do abuso de poder;

- Quando tem maior probabilidade de acontecer;

- Quem recebe e quem é poupado;

- Conscientização da comunicação (Mahmoud, 2003).

A intervenção de terceiros pode configurar, então, como uma importante aliada contra a opressão, pois pode ser um efetivo meio de capacitação e autonomia para superação da dinâmica. Os métodos de superação complementares podem ser um novo trabalho, voltar a estudar, retomar ou começar a ter acesso a outras pessoas importantes para apoio.

Esses duplo-vínculos podem ocorrer na maioria das relações sociais e familiares sem trazer prejuízos para seus membros. Alguns estudos criticaram a TDV por patologizar excessivamente as 
relações paradoxais. Os críticos da TDV afirmam que essas dinâmicas seriam naturais e necessárias para o desenvolvimento humano (Cronen et al., 1982).

O Grupo de Palo Alto Eles não teve a pretensão de patologizar as relações familiares. Bateson e os demais integrantes desse grupo reconheceram desde o início da elaboração da TDV que muitas experiências duplo-vinculares acontecem de maneira isolada e que o problema surge quando esses aspectos tornam-se duradouros e estruturam o padrão da relação. Para Watzlawick et al. (1967/2007), "não há dúvida de que o mundo em que vivemos está longe de ser lógico e de que todos temos estado expostos a duplas vinculações, mas apesar disso, quase todos nós temos logrado êxito em preservar a nossa sanidade mental" (p. 193).

A TDV mostra, inclusive, que existem vários aspectos positivos dos paradoxos. Eles podem ser terapêuticos e transformadores. Para Watzlawick et al. (1967/2007), "muitas das mais nobres iniciativas e realizações do espírito humano estão intimamente ligadas à capacidade do homem para experimentar os paradoxos. Fantasia, jogo, humor, amor, simbolismo, experiência religiosa (...) e a criatividade nas artes e nas ciências, parece serem essencialmente paradoxais” (p. 231).

As dinâmicas duplo-vinculares impactam todas as áreas das relações humanas. A TDV deve ser ampliada para além da saúde mental (Watzlawick et al., 1967/2007). A aplicação dos critérios da TDV aos casos de violência conjugal pode ajudar a identificar elementos dessas dinâmicas, os riscos presentes nesses relacionamentos e alguns caminhos para a sua superação. A avaliação de risco pode ser realizada pelos profissionais e mesmo pelas pessoas envolvidas na relação: mulheres, homens, familiares, amigos e comunidade.

Machado (2014) afirma que sempre haverá um duplo significado que precisa ser desvendado no contexto da violência conjugal, que vai além de profundas análises dos atos violentos, sua repercussão e avaliação de riscos. Nesse contexto, as considerações sobre vontade e autonomia da mulher precisam "ser reconfiguradas porque devem ser pensadas como construídas e contextualizadas no decorrer dos processos de conflitos. Mudanças de opinião não são irracionais, mas derivadas do andar das relações, e sua complexidade precisa ser entendida” (p. 15).

Nesse trabalho, partimos do pressuposto que é imprescindível identificar como os critérios de duplo-vínculos se manifestam na dinâmica conjugal marcada pela violência. O processo de identificação desses critérios é complexo e difícil, mas pode ser um primeiro passo para iniciar o longo percurso de superação da violência conjugal. A identificação de aspectos duplo-vinculares da relação deve fazer parte de um acompanhamento psicossocial mais amplo, para que, posteriormente, mulheres e homens possam retomar, aos poucos, suas condições de reflexão sobre o relacionamento e voltar a fazer escolhas conscientes sobre manter ou não o vínculo conjugal. A 
inclusão da população masculina nesse processo é fundamental para a busca de compreensão de suas necessidades, de apoio familiar e social e de mudanças e transformações pessoais e conjugais.

\section{Teoria do Duplo-Vínculo e violência conjugal}

Os paradoxos podem estar presentes em todas as relações conjugais. No entanto, os critérios de duplo-vínculos configuram uma dimensão estruturante e vão além das mensagens paradoxais nas dinâmicas relacionais marcadas pela violência. Como os elementos descritos nos critérios ficam arraigados à dinâmica conjugal, a mera constatação do episódio de violência não é suficiente para compreender, intervir e mudar um padrão relacional permeado pelo duplo-vínculo (Angelim \& Diniz, 2010).

Várias pesquisas (Hamilton \& Armstrong, 2009; Mahmoud, 2003) defendem a importância de se discutir a dinâmica duplo-vincular para ampliar a compreensão das relações sociais, familiares e conjugais. Entretanto, poucos estudos relacionam TDV e violência conjugal (Knickmeyer et al., 2003).

Nós localizamos três trabalhos que relacionam diretamente violência conjugal e a TDV. Knickmeyer et al. (2004) discutiram como algumas questões religiosas duplo-vinculares aprisionam as mulheres à dinâmica conjugal com violência. No contexto brasileiro, Angelim (2009) e Angelim e Diniz (2010) realizaram estudos sobre as mulheres vítimas de violência e os critérios de duplovínculo. Nessa tópico, pretendemos contextualizar como homens autores de violência conjugal podem ser inseridos na TDV.

Grande parte dos estudos sobre duplo-vínculo abordaram as pessoas vítimas desse padrão, que ficam em situação de desvantagens mais visíveis nas relações de poder. Não encontramos estudos que relacionem duplo-vínculos e os aspectos das masculinidades inseridas em violência conjugal. Watzlawick et al. (1967/2007) afirmam que o duplo-vínculo não pode ser na natureza da comunicação humana um fenômeno unidirecional. Esse padrão aprisiona não só as pessoas vítimas, mas todos/as envolvidos/as. Essa dinâmica "produz um comportamento paradoxal, então esse mesmo comportamento, por seu turno, gera um duplo vínculo para quem o estabeleceu” (p. 193). Dessa forma, essa teoria ajuda na compreensão de que os homens autores também podem ficar presos a esse padrão.

As comunicações paradoxais vinculam todas as partes afetadas. Ambos os cônjuges ficam presos a armadilhas que eles mesmos armam em uma relação conjugal com violência. Contudo, essas pessoas não percebem como sair dessas armadilhas (Watzlawick et al., 1967/2007).

Daí a importância da rede familiar, social e/ou institucional para suprir o que o sistema conjugal ou familiar dificilmente seria capaz de gerar: uma mudança de suas próprias regras. Esses padrões comumente impossibilitam a geração de "qualquer mudança de dentro para fora e o fato de 
uma mudança poder ocorrer somente no caso de se sair do padrão" (Watzlawick et al., 1967/2007, p. 211). Alves et al. (2012) corroboram essas ideias, afirmam que na violência conjugal todos/as são atingidos/as e tornam-se, ao mesmo tempo, vítimas e autores da dinâmica relacional.

Os homens podem ficar simultaneamente aprisionados a condições de agentes e de grandes vítimas de um modelo tradicional e violento de socialização. Eles podem se sentir reféns das diversas exigências sociais. Muitos homens podem perder ou tirar a vida de outras pessoas na busca de afirmação de um sexo social. A vulnerabilidade dos homens à violência é agravada por sua socialização (Alves et al., 2012).

O modelo de masculinidade hegemônico pode personificar diversos duplo-vínculos aos homens atualmente. Norman (2011) realizou uma pesquisa no Canadá para verificar os aspectos das masculinidades que aprisionam homens jovens. Ele constatou características relacionadas à saúde, heterossexualidade e individualismo que têm grande influência na saúde mental de homens jovens. As pressões sociais impõem diversos dilemas para os homens. Ao mesmo tempo em que eles são influenciados a reproduzir alguns privilégios das masculinidades, são simultaneamente estimulados a se oprimirem e se distanciarem de seus sentimentos.

O estudo mostrou a importância de homens jovens negociarem e resolverem esses duplovínculos das masculinidades para melhorar a sua saúde mental e favorecer melhores relacionamentos com outros homens e com as mulheres. A superação desses padrões é fundamental para a população masculina se libertar das diversas opressões impostas socialmente aos homens (Norman, 2011).

Angelim (2009) e Angelim e Diniz (2010) afirmam que uma relação marcada pela violência conjugal pode ser considerada duplo-vincular a partir da constatação da presença de pelo menos três das condições elaboradas por Watzlawick et al. (1967/2007): 1) Uma pessoa de valor afetivo importante e com valor de sobrevivência; 2) Mensagens paradoxais; e 3) Impossibilidade de refletir sobre a relação.

A distinção entre violência em geral e a violência conjugal realizada por Toneli et al. (2010) ajuda a compreender a importância do conceito de duplo-vínculo. Esses/as pesquisadores/as afirmam que a violência é algo que extrapola os limites das pessoas, invade e desestrutura a subjetividade. A violência conjugal é "vivenciada por alguém que tem lugar de referência para aquele que sofre a situação (...) é um processo que mistura sentimentos contraditórios de amor e ódio” (p. 15). Essa definição abrange os três principais critérios de duplo-vínculo discutidos a seguir. 


\section{$1^{a}$ Condição: valor de sobrevivência}

Essa condição é baseada no valor de sobrevivência que uma pessoa tem em relação ao cônjuge. Esse valor é estruturado na crença de não conseguir sobreviver sem a presença do/a outro/a. A pessoa percebe na outra um valor afetivo imprescindível em sua vida, mesmo quando a relação torna-se bastante adversa - como no caso de violência conjugal. Nesses casos, pode haver uma forte dependência entre os membros do casal, que favorece a instalação de dinâmica de submissão e de necessidade do reconhecimento da pessoa amada (Watzlawick et al., 1967/2007).

A vivência de afeto, especialmente de amor em relação ao/à parceiro/a, é importante para o relacionamento e para a construção da própria identidade (McGoldrick, 1994). A ideologia do patriarcado deturpa esse ideal de amor preconizado pela sociedade, pois impõe que as mulheres vivam em função dos cônjuges, mesmo que seja em detrimento de suas necessidades e desejos pessoais. Prevalece, então, a ideia paradoxal de que as mulheres devem esquecer de si mesmas e privilegiar o cuidado com o parceiro e os filhos. Nesse contexto, tendem a se sentir obrigadas a suportar tudo - inclusive a violência - para manter sua família (Angelim, 2009; Diniz \& Pondaag, 2004, 2006; Pondaag, 2009).

Os homens também aprendem a violência através da socialização (Beiras et al., 2012). A socialização de gênero é tão importante que afeta diretamente a subjetividade dos homens. Ela é retroalimentada pela cultura, sociedade e experiências individuais (Beiras \& Cantera, 2012; PonceAntezana, 2012).

A identidade de homens e mulheres é reiterada nas trajetórias, nas relações. É um grande equívoco tentar essencializar e generalizar a experiência de vida das mulheres e homens em situação de violência conjugal (Gregori, 1993). Fávero apoia-se na construção da subjetividade através da interação e adaptação do indivíduo com o meio sociocultural. Ponce-Antezana (2012) corrobora com a ideia dessas importantes autoras. Ele entende a subjetividade das pessoas como um produto social e histórico, que possui um vínculo estreito e em complemento com o gênero.

A instalação do valor de sobrevivência também está relacionada ao valor que a sociedade atribui aos papéis sociais de marido e esposa. Há, inclusive, um status social diferenciado para homens e mulheres casados/as. Fica a ideia de que o casamento promove maior serenidade, amadurecimento e respeito. Essa valorização social pode dificultar pensar em outra possibilidade senão continuar na relação conjugal (Souzas \& Alvarenga, 2001).

A confiança aliada à insegurança também podem favorecer esse valor de sobrevivência ao aumentar a vulnerabilidade dos membros do casal ao paradoxo. O dilema seria impossível se não houvesse confiança. O ciúme conjugal é um exemplo dessa vulnerabilidade. Frequentemente o ciúme aparece como um silencioso desespero, que influencia na busca de uma patologia do outro ou 
de ambos, favorecendo a desresponsabilização pelas agressões (Watzlawick et al., 1967/2007). Para esses pesquisadores, o ciúme contribui para a tentativa de controlar o/a parceiro/a, pois "não há na natureza da comunicação humana maneira alguma de fazer com que outra pessoa participe na informação ou nas percepções que estão exclusivamente ao nosso alcance (...) o outro poderá confiar ou não, mas nunca poderá saber” (p.205).

Os indícios de um relacionamento marcado pelo valor de sobrevivência podem ser identificados nas justificativas que ambos apresentam para a manutenção da relação conjugal. Geralmente são expressas pelas mulheres em audiência e nos pedidos de arquivamento do processo judicial. Elas enfatizam o papel de pai e trabalhador do ex/parceiro. Essas justificativas mostram a prioridade da manutenção da família e a valorização do papel do homem em detrimento da sua própria integridade e sua saúde (Angelim, 2009; Angelim \& Diniz, 2010).

De forma complementar, os homens revelam muitos motivos para permanecerem na relação e justificar a violência contra suas ex/companheiras. As justificativas revelam a naturalização da violência, a desigualdade na relação conjugal e reforçam o valor de sobrevivência em relação à parceira. A imposição de papéis sociais favorece a dependência entre os cônjuges ao dispor os homens como provedores e dominadores e as mulheres como subordinadas (Separavich \& Canesqui, 2013; Souzas \& Alvarenga, 2001).

Muitos homens se sentem dependentes de uma companheira para cuidar deles. Ao mesmo tempo, eles são estimulados socialmente a serem independentes. Esse conflito favorece a utilização de algumas estratégias de duplo-vínculo usadas simultaneamente de forma consciente e inconsciente para a perpetuação da violência. Geralmente as estratégias são justificadas por vários comportamentos baseados em valores sociais internamente arraigados (Mahmoud, 2003).

Essa dependência de alguns homens autores de violência fica mais evidente com as justificativas das agressões pelo abuso ou dependência de álcool. Essas justificativas têm uma dimensão consciente/visível, em que o consumo de álcool atua como desinibidor, favorece o aumento da violência e mostra virilidade dos homens. A dimensão inconsciente/invisível atua como justificativa para ficar na relação. A necessidade de ser cuidado pela parceira reforça a manutenção da relação e da violência conjugal (Mahmoud, 2003).

O consumo de álcool é usado como justificativa pelos homens como forma de autodesculpabilização, racionalização ou neutralização da violência. O abuso de álcool, desemprego, estresse e vários outros motivos favorecem a desresponsabilização do homem pela violência e como justificativa para mulheres permanecerem na relação e cuidar do parceiro, que muitas vezes é visto como um "doente" e que precisa de cuidado. Esses fatores favorecem para que tanto o homem quanto a mulher permaneçam na relação, que percebam o/a outro/a como uma 
pessoa de valor afetivo imprescindível a sua sobrevivência. Essa dependência dificulta imensamente a adoção de estratégias de autocuidado e autoproteção, tanto de homens quanto de mulheres envolvidos/as na violência conjugal. (Aguiar, 2009; Guimarães, 2009; Grossi, 1999; Manita, 2008; Schmidt, 2010; Watzlawick et al., 1967/2007).

Uma forma para compreender, favorecer a manifestação e lidar com esse valor de sobrevivência é por meio de metáforas. Elas podem estimular a capacidade de reflexão de homens e mulheres atendidos/as. As metáforas possibilitam pensar em soluções e alternativas a partir da própria vivência e da experiência de vida de cada pessoa. Essa técnica é muito utilizada nas terapias de família pós-modernas, mas pode ser usada em vários contextos além do terapêutico, inclusive nos casos de violência conjugal (Anacleto, 2000; Grandesso, 2001; Zordan et al., 2012). Anacleto enfatiza que:

tal técnica deve ser utilizada principalmente em famílias com sistemas rígidos e resistentes que apresentam certa dificuldade em aceitar mudanças. Nesse caso, utilizo frases prontas, provérbios, alguma história ou filme relacionado ao problema apresentado, para que possamos refletir juntos o significado daquela situação e procurarmos uma forma de mudar a visão de mundo daquele grupo familiar, quebrando um pouco a rigidez para facilitar a compreensão do problema e o entendimento da intervenção (Anacleto, 2000, p. 46).

Utilizamos algumas metáforas para lidar com o valor de sobrevivência das pessoas em situação de violência conjugal, dentre elas o livro "Mas ele diz que me ama" (Penfold, 2005/2006). Elas podem ser empregadas em intervenções grupais para ajudar na reflexão sobre a importância da autonomia, do empoderamento pessoal e da adoção de estratégias para o autocuidado.

Essas metáforas são apenas uma pequena parte de todo um contexto de intervenção mais amplo. No entanto, podem ser muito úteis para iniciar a identificação e ampliar a reflexão sobre a revisão do valor afetivo e de sobrevivência. Essa revisão propicia a abertura de caminhos para a superação da dinâmica permeada por contradições e ambivalências. Especialmente para confrontar e desconstruir mensagens paradoxais, que aprisionam ainda mais os cônjuges à relação.

\section{$2^{a}$ Condição: presença de mensagens paradoxais}

A violência é por si só uma contradição ao amor, que é o sentimento básico esperado socialmente em uma relação conjugal. Os ideais de amor são reforçados a todo o momento pela sociedade, por meio de mitos, filmes, novelas, contos de fadas, músicas, transmissão transgeracional etc. (Diniz, 2011; Guimarães, 2009).

Saffioti (1999) argumenta que ainda se constitui uma utopia esperar que todos os seres humanos amem uns aos outros, mas é essencial o respeito. O amor depende também da convivência e "não constitui uma obrigação, mesmo porque o amor não nasce da imposição. Respeitar o outro, sim, constitui um dever do cidadão, seja este outro mulher, negro, pobre” (p. 85). Mesmo que não 
haja amor, a violência constitui um paradoxo em relação ao respeito ao/à outro/a e à dignidade humana.

A violência é uma práxis contraditória e ambígua. Ela promove a deslegitimação da outra pessoa em prol do êxito próprio. No contexto de violência conjugal, existem elementos muito fortes do amor romântico, da valorização do sofrimento, da violência e das tragédias passionais. Há uma valorização social de sentimentos paradoxais de prazer e dor como condição para alcançar a felicidade. Há uma linha tênue entre o que é amar e o que é sofrer, que favorece a naturalização da violência (Teixeira, 2009).

No entanto, a violência não pode ser vista como alheia ao sistema social. Ela é simultaneamente reprovada em determinados âmbitos e sentidos, mas legitimada e validada em outros contextos. Essa condição paradoxal da violência é tão evidente que se torna invisível em muitas relações sociais e familiares, principalmente nas dinâmicas conjugais (Ponce-Antezana, 2012).

Medrado e Méllo (2008) reafirmam essa visão paradoxal da sociedade em relação à violência. Muitas manifestações aceitas e, geralmente, estimuladas culturalmente pela própria sociedade são as portas de entrada para a violência de gênero, inclusive as mais graves que atuam contra a vida de muitas mulheres e dos próprios homens.

Outros crimes vão contra os ideais da sociedade, que se posiciona claramente contra o roubo, estelionato, assassinato, etc. No caso da violência conjugal, a sociedade age paradoxalmente. Ela atua como promotora e como punitiva por meio de mensagens contraditórias na mídia, piadas sexistas, escolas, etc. Os mitos sociais colaboram para a propagação desses paradoxos do ponto de vista simbólico (Diniz \& Angelim, 2003; Medrado \& Méllo, 2008).

As expectativas sociais em torno dos papéis de mulher, mãe e esposa são perpassadas por mensagens contraditórias e, muitas vezes, paradoxais. Essas expectativas preconizam que mulheres devem tolerar tudo, inclusive as agressões, para serem/sentirem-se legitimadas e reconhecidas como sujeito feminino (Diniz, 1999, 2011). Angelim e Diniz (2010) defendem que "reconhecer os paradoxos presentes nesse processo de construção identitária e sua ancoragem nas expectativas e papéis de gênero socialmente construídos constitui um desafio para todas as mulheres, mas em especial, para mulheres vítimas de violência” (p. 404).

Nós acreditamos que esse também é um desafio para os homens, principalmente aos que exercem ou exerceram violência conjugal contra suas ex/parceiras. A população masculina precisa se conscientizar das mensagens paradoxais da sociedade em seu processo de socialização. Essas mensagens repercutem diretamente na forma dos homens se relacionarem com suas companheiras e favorecem, inclusive, a instalação e perpetuação da violência conjugal. Medrado e Méllo (2008) 
corroboram essa ideia ao afirmarem que "o mesmo sistema de poder que autoriza os homens a agirem de modo agressivo e fazer valer os seus direitos sobre as mulheres em nome da honra é o mesmo sistema de poder que os coloca em situação de vulnerabilidade" (p. 81).

A vulnerabilidade masculina diante dos paradoxos da sociedade também é reconhecida por Maciel e Barbosa (2010). Esses/as pesquisadores afirmam ser imprescindível reconhecer que a supremacia atribuída ao masculino também o expõe e fragiliza. Há um paradoxo entre os privilégios e as fragilidades dos homens que potencializa a violência.

Alves e Diniz (2005) pesquisaram os discursos sobre a violência conjugal de homens que tiveram relacionamento conjugal por no mínimo dois anos. O discurso deles mostrou a manutenção e a reprodução de preconceitos sobre as funções e papéis sociais da mulher, especialmente a percepção da inadequação de suas parceiras em exercer o seu papel social. Os homens tiveram uma visão infantilizada das mulheres, eles consideraram que elas não sabem tomar decisões e que precisam ser controladas e punidas quando não obedecem ao parceiro.

Eles compreenderam que elas precisam de um homem para cuidá-las, protegê-las e orientálas. A partir desse discurso de proteção, entenderam como direito dos homens tirar a autonomia e a liberdade da mulher. Essa percepção paradoxal sobre as mulheres favorece a instalação da violência, que é desencadeada e justificada caso suas parceiras não lhes obedeçam (Alves \& Diniz, 2005).

Os aspectos paradoxais dos discursos dos homens podem aprisioná-los ou apontar para possibilidades de mudanças nos relacionamentos conjugais (Silveira et al., 2009). As mensagens ambíguas não possuem apenas aspectos negativos. No caso violência conjugal, Silveira et al. afirmam que pode atuar como fator que potencializa mudanças na resolução dos conflitos. A variabilidade das narrativas de alguns homens pode indicar o reconhecimento do caráter relacional das situações de conflito conjugal, embora, ao mesmo tempo, identifiquem que tais situações foram provocadas exclusivamente pelas mulheres.

As narrativas de homens autores aparecem permeadas por sentidos contraditórios. Ao mesmo tempo em que se desresponsabilizam e culpabilizam as mulheres pelos conflitos conjugais, por colocá-las no papel de "provocadoras" e "agressivas", os homens também relataram ocasiões que explicitam minimamente o seu papel na construção relacional dos conflitos. A violência conjugal nesses casos não aparece apenas como "provocadas" pelas mulheres, mas fazendo parte de um jogo relacional conflituoso do qual ele é simultaneamente partícipe e corresponsável (Silveira et al., 2009).

O estudo de Silveira et al. (2009) sobre as narrativas de homens foi importante para mostrar a pluralidade do discurso de homens autores de violência, pois revelou a coexistência de vários 
significados que se sobrepõem, se misturam, se contradizem e estão permanentemente em conflito. Há um emaranhamento de concepções sobre sexualidade, família, gênero, afetividade, educação, etc. Assim, uma leitura simplista sobre a questão é insuficiente e incoerente com a diversidade de situações (Silveira et al., 2009). A identificação desses paradoxos nos discursos dos homens que simultaneamente os desresponsabilizam e indicam um início do processo de responsabilização pode ajudar na reflexão dos aspectos que mantém a violência, mas também de outros que abrem um potencial de superação desse padrão - seja mantendo a relação ou por meio da separação do casal.

A TDV pode ser importante para ser um dos meios de leitura para abranger a complexidade das mensagens paradoxais das narrativas de homens e de mulheres em situação de violência conjugal. Nesse sentido, discutimos três indícios importantes da força das mensagens paradoxais no contexto da violência que se manifestam nos discursos de homens e mulheres: a negação da violência; as justificativas das agressões e a minimização por meio da ambiguidade de sentimentos (Angelim, 2009; Angelim \& Diniz, 2010).

O primeiro indício ocorre quando a mulher e o homem interpretam o episódio de violência como demonstração de afeto, favorecendo a negação das agressões. Essa contradição tem o ciúme como principal elemento. Ao perceberem o ciúme como expressão intensa de amor, eles/as podem assumir posição compreensiva e paradoxal: um pode valorizar o "sofrimento" do outro/a parceiro/a manifesto pelo ciúme e buscar mudar e restringir seus próprios comportamentos para não "provocar" ira do/a outro/a (Angelim, 2009; Angelim \& Diniz, 2010). Muitas pessoas nessa situação não percebem a violência, negam as agressões por entendê-las como expressão do amor por meio do ciúme.

O ciúme excessivo não tem como base o amor, mas sim o sentimento de insegurança, de controle e de posse. O ciúme é fenômeno complexo permeado por sentimentos, comportamentos e ideias influenciados por questões socioculturais, transgeracionais e individuais. Geralmente quando o ciúme é apresentado pelos homens, as mulheres podem também ver os seus parceiros como doentes e que precisam ser cuidados por elas. Essa interpretação pode aprisioná-las ainda mais à relação. A separação pode ser vista como sinônima de abandono e elas podem sentir-se extremamente culpadas por isso (Guimarães, 2009; Silva \& Sattler, 2015; Teixeira, 2009).

As justificativas utilizadas pelas mulheres e homens para naturalizar a violência e suas consequências constituem outros indícios da existência de mensagens paradoxais, especialmente por meio de explicações simplistas. As violências verbais ou empurrões podem ser percebidos e explicados por ambos como atitudes para evitar agressões maiores. As mulheres podem perceber as agressões como gestos involuntários ou atos reflexos do parceiro. Os homens geralmente se 
desresponsabilizam pelas agressões. Ambos atribuem a violência a fatores externos, frequentemente ao álcool ou ao abuso de outras drogas (Angelim \& Diniz, 2010; Guimarães, 2009).

O terceiro indício de um relacionamento marcado por mensagens paradoxais é a minimização da violência por meio da ambivalência de sentimentos. Homens e mulheres em situação de violência conjugal tendem a se sentirem extremamente confusos/as - não sabem se amam ou odeiam o/a parceiro/a; se têm afeto ou raiva, se têm compaixão ou revolta. A ambivalência de mulheres fica evidente nos pedidos de arquivamento de processos judiciais e na disposição para cuidar do parceiro (Angelim, 2009; Angelim \& Diniz, 2010).

A ambiguidade de sentimentos dos cônjuges também aparece no ciclo de violência, em que se instala um padrão de diversos términos e retornos à relação. Terminar e reconciliar a conjugalidade evidencia a coexistência da expectativa de sair da relação e a esperança de mudança na sua dinâmica (Guimarães, 2009; Walker, 1999). Essa dinâmica relacional torna os cônjuges prisioneiros do paradoxo entre amor e agressão.

Tanto homens quanto mulheres permanecem, mas a pressão social e as cobranças recaem injusta e exclusivamente com mais frequência sobre a mulher. Por ser a pessoa em condição de desvantagem e marcadas pelas desigualdades de gênero na relação conjugal, as mulheres podem se sentir obrigadas a resolverem sozinhas todos os problemas familiares. Esse dilema as coloca diante de outro paradoxo: "ficar para resolver ou sair para resolver? Elas ficam presas em uma armadilha: se ficam são criticadas, acusadas de gostar de apanhar; se saem, são fracas e acusadas de provocarem a ruptura familiar" (Guimarães, 2009, p. 69).

Essa culpabilização das mulheres e a desculpabilização dos homens são reforçada pelas desigualdades de gênero. As mulheres falham se abandonam e falham se conformam com a relação. Com os homens acontecem o oposto, frequentemente são desculpados por ter perdido o controle (Fávero, 2010).

A ambivalência de sentimento atinge seu extremo quando ocorre o paradoxo entre amor e ódio. A dinâmica de violência pode aumentar de intensidade e de frequência até atingir um fim trágico: a morte de um dos cônjuges, na grande maioria dos casos da mulher. A tendência é ocorrer o feminicídio (Krug, Dahlberg, Mercy, Zwi \& Lozano, 2002; Waiselfisz, 2012, 2015) ou o homicídio da mulher seguido de suicídio do homem (Aguiar, 2009; Angelim, 2009; Macedo, 2013; Teixeira, 2009).

A dinâmica duplo-vincular presente nessa situação não permite alternativas fora da relação, senão a morte dos cônjuges. Ambos ficam aprisionados a esse padrão de relacionamento (Angelim \& Diniz, 2010). A socialização tradicional de homens contribui para a adoção de soluções drásticas quando o homem encontra obstáculos à sua masculinidade, inclusive o homicídio e o suicídio 
(Alves et al., 2012). O livro "Nunca você sem mim: homicidas-suicidas nas relações afetivoconjugais" (Teixeira, 2009) e o artigo "Matar e, depois morrer" (Soares, 2002) ilustram bem como a conjugalidade marcada pela violência pode evoluir até o desfecho trágico de um homicídio-suicídio.

As mensagens paradoxais emitidas em um contexto relacional de grande valor afetivo contribuem significativamente para dificultar ou impossibilitar a reflexão sobre a violência conjugal. A seguir descrevemos como essa impossibilidade de reflexão contribui para que homens e mulheres fiquem aprisionados/as à relação conjugal.

\section{$3^{a}$ Condição: impossibilidade de refletir sobre a relação}

A terceira condição do duplo-vínculo nas relações conjugais com violência é marcada pela extrema dificuldade ou impossibilidade de reflexão sobre a sua própria dinâmica. Um ingrediente essencial nessas relações é a proibição de estar consciente dos paradoxos implícitos (Watzlawick et al., 1967/2007).

Espera-se que homens e mulheres consigam se afastar facilmente de dinâmica conjugal estruturada por violência. Essa expectativa é injusta, simplista e ingênua, especialmente nas relações conjugais de longo tempo. Os processos psicológicos para a percepção e nomeação da violência são complexos. A tentativa de resolver ou sair da relação pode ter um alto custo emocional, social e financeiro para as pessoas envolvidas, principalmente para as mulheres. A decisão de sair da relação ou de buscar ajuda é longe de ser fácil, envolve grande risco, pois o perigo de novas agressões ou de homicídio aumenta nesses momentos (Fávero, 2010).

Discutiremos a seguir os principais fatores que impedem ou dificultam a reflexão sobre a relação. As questões que mais aprisionam homens e mulheres nessas dinâmicas são: os papéis tradicionais de gênero; o silêncio e o segredo como estratégias de enfrentamento à violência; a instalação das anestesias relacionais; o ciclo da violência; a escalada gradual da violência; e o isolamento social da família. Não tivemos a pretensão de ser exaustivos, pois existem inúmeros outros motivos que favorecem a perpetuação da violência conjugal.

Os papéis tradicionais de gênero embasam a naturalização da violência conjugal pelos homens e pelas mulheres de forma complementar. Simone de Beauvoir (1967, 1946/2000) defende que existe uma estereotipia do comportamento feminino, em que as mulheres ficam subjetivamente dependentes do lócus conjugal e familiar. Essa expectativa social por si só é um fator que dificulta a reflexão das mulheres sobre sua condição subjetiva (Angelim, 2009; Diniz, 1999).

A socialização de homens - por meio da influência de seus pares, da família e da sociedade como um todo - favorece a utilização da violência como algo natural, inclusive contra as parceiras (Fávero, 2010). Os obstáculos ao cumprimento das imposições sociais aumentam a vulnerabilidade dos homens para o envolvimento com condições violentas (Alves et al., 2012). 
Dessa forma, os homens ficam com extrema dificuldade de reconhecer e falar sobre a violência. As mulheres têm papel complementar à agressividade do papel masculino, pois são encorajadas a culpabilizar a si mesmas pelas agressões sofridas. Forma, assim, um "laço duplo", em que ambos ficam com extrema dificuldade de perceber e refletir sobre as consequências da relação marcada pela violência conjugal (Fávero, 2010).

O uso do silêncio e segredo também dificulta a reflexão sobre a relação (Diniz \& Pondaag, 2004, 2006; Pondaag, 2003, 2009). Mulheres podem ter dificuldade para verbalizar as experiências de agressão e nomeá-las como violência. Assim, tendem a utilizar o silêncio, o segredo e o não dito como estratégia de enfrentamento (Pondaag, 2009).

A instalação das anestesias relacionais na dinâmica conjugal e o uso do silêncio e do segredo como estratégias de sobrevivência revelam, portanto, outro paradoxo: apesar da dor e do sofrimento causado pela violência, a mulher fica sem condições e impedida de nomeá-la (Diniz \& Pondaag, 2006; Guimarães, 2009). A dificuldade em falar sobre a violência é um fator que atrapalha ou impede a formulação de um pedido de ajuda efetivo. Essa estratégia de sobrevivência contribui para a insatisfação e sofrimento da mulher na relação conjugal e cria obstáculos para a construção de sua autonomia (Pondaag, 2003, 2009).

O reconhecimento da violência também é difícil para muitos homens autores de violência (Ponce-Antezana, 2012). Esse pesquisador afirma que o sentido da violência não é sequer percebido pelos homens, pois "sem ser compreendido, narrado e nem nomeado e, portanto, as possibilidades de uma apropriação real de si mesmo para efetivamente assumir responsabilidades torna-se impossível, de maneira que a vivência fica uma vez mais localizada fora deles e das suas narrativas" (p. 18).

Em uma dimensão relacional, o ciclo da violência também dificulta a percepção e a reflexão sobre a situação da relação com violência (Walker, 1979, 1999; Walker, Duros \& Tome, 2007). A repetição do ciclo faz com que as mulheres e os homens se adaptem aos altos e baixos da vivência conjugal. Diante do medo, a mulher vítima faz todo um movimento para eliminar questões associadas à percepção da violência: falta de autonomia pessoal, agressividade do parceiro, alterações do humor, rotinas, divisão de trabalhos domésticos, ciúmes etc. Muitas mulheres esperam que essa atitude possa mudar o comportamento do companheiro ou pelo menos evitar novas agressões (Saffioti, 1999). Esse processo pode levar a um estado de hipervigilância e de desamparo aprendido (Angelim, 2009; Walker, 1999).

A fase de Lua de Mel do ciclo da violência é a que mais favorece a perpetuação do relacionamento. Essa fase é marcada por um momento de paz e de reestruturação da conjugalidade após uma agressão maior. Ela é muito efetiva em impedir a reflexão sobre a violência na relação. 
Os homens e as mulheres colaboram de forma complementar para a permanência na relação nessa fase. O homem pode dar assistência à mulher, pedir desculpas, mostrar-se arrependido e com remorso, fazer promessas e usar mecanismos de sedução. Mais do que uma tentativa de enganar a parceria, muitos homens têm convicção de que conseguirão não recorrer mais à violência. Muitas mulheres tentam acreditar e criam esperança de que o parceiro realmente possui capacidade para mudar (Walker, 1999).

Essa expectativa de mudança na relação dificulta a reflexão do casal sobre a dinâmica da violência e, sem a busca de ajuda efetiva, a tendência é a retomada das fases mais violentas do ciclo. Os momentos de tranquilidades tendem a ficar cada vez mais curtos e raros (Guimarães, 2009; Guimarães, Silva \& Maciel, 2007; Soares, 2005; Walker, 1999).

Cantera (2007) fez várias críticas importantes sobre o ciclo da violência com o objetivo de fortalecer essa teoria. Ela pontuou a importância de considerar as diferentes conjugalidades marcadas pela violência e criticou, principalmente, o fato de o conceito não incorporar as dimensões sociais e culturais da violência. Assim, essa pesquisadora recorreu a alguns estudos importantes que realizaram múltiplas variações do modelo no intuito de abranger as pluralidades das relações conjugais e abarcar melhor os fatores sociais.

Cantera (2007) cita o modelo da "Espiral da Violência", que foi apresentado por Garro (1992). A espiral inclui uma sequencia cíclica de acumulação, agravamento e expansão do ciclo. Essa sequência progride em 4 fases: normalização, condutas violentas, repetição e adaptação. Garro descreveu também um modelo semelhante a um "Efeito de Bola de Neve", em que a dinâmica vai se agravando e se reconfigurando a cada ciclo. Ele tentou articular os planos interindividual e estrutural da violência conjugal.

Outro modelo que ficou conhecido como "Roda de Violência" foi proposto por Inés (1996). As relações de poder foram inseridas em cada eixo da roda para incluir o exercício de poder e controle da pessoa autora de violência sobre o/a cônjuge. Por último, o "Modelo CEMUJER" (1996) incluiu janelas na periferia do círculo, em que essas janelas abrem ao exterior e abrangem a comunidade, vizinhança, escola, etc. (Cantera, 2007).

Schmidt (2010) realizou atualização e ampliação relevante do ciclo da violência. Ele estudou a integração do ciclo de violência e do ciclo do alcoolismo nas conjugalidades para analisar a construção subjetiva dos homens autores de violência e alcoolistas. Ele constatou que o uso, abuso ou dependência de alcool apresenta uma função paradoxal no ciclo da violência.

Os homens compreenderam o consumo de álcool como fornecedor de alívio para lidar com as tensões do relacionamento. Ao mesmo tempo, o consumo dessa substância contribui significativamente para o aumento ou explosão das tensões, facilitando a re/instalação das 
agressões. O acompanhamento psicossocial oferecido pelo Estado foi percebido pelos participantes do estudo como fundamental para refletir sobre o papel paradoxal da violência e do álcool (Schmidt, 2010).

Os múltiplos modelos de ampliação do ciclo da violência têm em comum a possibilidade de contemplar melhor a complexidade de diferentes relações conjugais marcadas pela violência e a interlocução da dinâmica relacional com aspectos sociais. Esses modelos abrangem também como as agressões podem agravar e a relação se reconfigurar em novas dimensões que dificultam cada vez mais a capacidade das pessoas de perceber e refletir sobre a violência.

A escalada gradual da violência é outro fator que dificulta a percepção e a reflexão sobre a violência. Raramente as agressões iniciam com suas formas mais graves. Elas começam em suas formas mais sutis e vão aumentando em intensidade e frequência. A violência comumente se instala com agressões psicológicas por meio de palavras, gestos e olhares. Inicia-se com o controle sobre roupas, isolamento social, desistência de metas e de objetivos. Ela progride para o cerceamento da liberdade individual, controle, constrangimentos, humilhações, chantagens emocionais. Antes de acontecer alguma violência física, alguns homens baixam ou destroem a autoestima de suas parceiras, o que aumenta a chance de elas tolerarem as outras agressões (Fávero, 2010; Guimarães, 2009; Hirigoyen, 2005/2006; Silva, 2012; Silva, Coelho \& Capone, 2007; Soares, 2005).

Há um continuum crescente de condutas abusivas. Homens e mulheres contribuem para a instalação e escalada da violência conjugal. Alguns homens utilizam insultos, negação do universo afetivo, desaprovação e culpabilização, injúrias (puta, louca, estúpida, etc.), desqualificação como mãe, esposa, amante, profissional, exigência de atenção exclusiva, crítica em público, relato de aventuras com outras mulheres, ameaça de outras violências contra ela e os filhos (Fávero, 2010; Silva et al., 2007).

As mulheres também tendem a justificar a violência do parceiro e a legitimar as atitudes dele. É muito comum ouvir os seguintes relatos de mulheres vítimas:

- "Ele estava nervoso, não fez porque quis";

- "Ele tinha bebido um pouco, se estivesse sóbrio não o faria";

- "Ele tinha razão para ficar chateado, pois o meu vestido não estava bom";

- "Eu deveria estar pronta. Pelo meu atraso, ele ficou irritado e fez o que fez..." (Fávero, 2010, p. 275).

Vale ressaltar, que reconhecer a contribuição das mulheres na manutenção da relação é totalmente diferente de culpabilizá-las pela violência. Elas podem ser corresponsáveis pela perpetuação do relacionamento, mas nunca pela agressão sofrida. 
O isolamento social da família também dificulta ou impossibilita a reflexão sobre a relação (Angelim \& Diniz, 2010; Soares, 2005). O isolamento do casal atua como uma consequência da violência e ao mesmo tempo como um fator de risco - contribui para a formação de um círculo vicioso e favorece a sua perpetuação (Guimarães, 2009).

Esse isolamento é muito comum em famílias em situação de violência e ocorre quando as pessoas perdem ou diminuem significativamente o contato com seus parentes, amigos e comunidade. As consequências do isolamento geralmente têm mais peso sobre as mulheres. É muito comum que homens autores de violência tentem impedir de todas as maneiras que a parceira estude, trabalhe e circule livremente (Soares, 2005; Alves \& Diniz, 2005).

Os homens ainda apresentam dificuldade em contar com a rede como meio de suporte, mesmo quando tem acesso a muitas pessoas. Isso acontece com homens em geral, mas especialmente com homens em dinâmica de violência conjugal. A socialização tradicional de gênero dificulta que eles conversem sobre suas dificuldades e necessidades. Essa dificuldade ou inabilidade comunicacional aparece mesmo quando estão em imenso sofrimento emocional e com processos na justiça (Aguiar, 2009; Dohmen, 2006, 2006a; Maciel \& Barbosa, 2010).

Diante de tantos fatores que aprisionam homens e mulheres, é preciso promover ou aprimorar a capacidade de percepção e de reflexão dos/as envolvidos/as na dinâmica conjugal com violência (Angelim, 2009; Macedo, 2013; Pondaag, 2009). A recuperação de recursos de reflexão de homens e mulheres inseridos nessas dinâmicas pode estabelecer limites para o próprio significado da experiência de violência, podem ajudá-los a superar o padrão de relacionamento duplo-vincular de violência e ampliar a capacidade de avaliar os riscos da violência. Por fim, podem imprimir mais clareza à denúncia das mulheres junto ao Estado (Angelim, 2009; Angelim \& Diniz, 2010).

Uma mulher inserida em uma dinâmica duplo-vincular está em situação vulnerável. A probabilidade de seu retorno para o relacionamento é alta - mesmo que ele seja permeado pela violência, que não tenha nenhuma perspectiva de mudança, e, inclusive, após a mulher ter buscado ajuda de familiares, amigos e da Justiça. Esse processo leva a um desgaste e descrédito junto à sua rede de apoio familiar e institucional (Angelim \& Diniz, 2010). Os autores enfatizam que:

enredada num padrão de relacionamento duplo-vincular a vítima e o agressor não dispõem de condições para superar o padrão relacional violento. (...) Esse padrão relacional inviabiliza até mesmo a compreensão de como começaram as agressões. Daí que nesses casos a percepção do padrão relacional torna-se, por vezes, mais importante que o esclarecimento da causalidade linear e dos motivos que permitem os episódios de violência (Angelim \& Diniz, 2010, p. 402).

Uma das poucas formas de tentar buscar ajuda para romper ou superar a violência é por meio da denúncia dos parceiros. Muitas mulheres recorrem à justiça para gerenciar a crise do 
relacionamento. Essa busca não significa necessariamente o rompimento com a dinâmica conjugal. Algumas mulheres tem a intenção de separar, mas a maioria tem o desejo de que a relação se transforme e tenha novas configurações, especialmente sem a violência (Silveira et al., 2009).

Muitos homens autores de violência têm dificuldade em compreender a denúncia como o único recurso das parceiras. Frequentemente eles se sentem se traídos e percebem a formulação da denúncia com muito sofrimento e decepção (Silveira et al., 2009). Para as mulheres, no entanto, dar conta de fazer a denúncia revela o processo de saída da anestesia relacional.

A denúncia tem o potencial de reconfigurar a relação a partir da intervenção da justiça e de terceiros. Nesse contexto, a justiça pode atuar com vários significados que vão além dos papeis punitivo e criminalizante. Ela pode se tornar um lugar privilegiado para resolução dos conflitos conjugais e de apoio psicossocial para homens e mulheres (Silveira et al., 2009). Em muitos casos, após a denúncia é que surge a primeira oportunidade de algum tipo de ajuda para homens, seja para acompanhamento psicossocial, para tratamento de abuso de álcool e outras drogas, para assistência social ou outro tipo de apoio (Aguiar, 2009; Guimarães, 2009).

Temos que expandir as opções de apoio que vão além da justiça. Homens e mulheres precisam ter outros espaços para recorrerem e receberem ajuda para aumentar as possibilidades de superação da violência. Os mecanismos podem ser estatais, tais como na saúde e na assistência social, bem como recursos a ações comunitárias, como, por exemplo, em OnG ou instituições religiosas. É importante que os profissionais tenham conhecimento da complexidade da violência, especialmente de teorias sistêmicas, para compreender aspectos que aprisionam essas pessoas à relação conjugal.

\section{Perspectiva sistêmica e aprisionamentos de homens autores}

A violência conjugal configura como um elo que aprisiona muitos casais ou ex-casais (Silveira et al., 2009). Por isso, a busca de ajuda externa é fundamental em vários casos. Os profissionais devem criar estratégias criativas para ajudar homens e mulheres a identificarem, perceberem e nomearem as anestesias relacionais que sustentam e naturalizam a violência, assim como auxiliar na compreensão dos critérios do duplo-vínculo que alicerçam a relação marcada pela violência conjugal. Esse pode ser o primeiro passo para ajudar as pessoas envolvidas nessas dinâmicas. Essa etapa é fundamental para que eles e elas possam buscar ajuda e proteção.

Um passo importante nesse sentido é entender melhor como a socialização de gênero influencia diretamente na forma com que os homens enxergam a violência conjugal. Esse padrão social ajuda a compreender o mecanismo de naturalização da violência que favorece para que as pessoas envolvidas "não vejam que não veem" as agressões e sigam uma lógica na qual percebem a conduta agressiva como coerente. Daí que o processo de naturalização da violência nos ajuda a 
compreender a instalação gradual de verdadeiras anestesias relacionais, ou "duplo cego", condição proposta por Ravazzola (1997). Os processos de negação, minimização e desresponsabilização de homens e mulheres dificultam a reflexão sobre a violência e podem favorecer, assim, o aprisionamento de ambos a um padrão relacional paradoxal e com grande investimento afetivo (Angelim, 2009; Angelim \& Diniz, 2010). Esse processo de naturalização da violência contribui também para a instalação de uma dinâmica duplo-vincular.

Essas teorias sistêmicas podem fornecer diversas ferramentas para os/as profissionais que atuam na área (Angelim, 2009; Angelim \& Diniz, 2010). O acompanhamento psicossocial aparece como uma poderosa oportunidade de reflexão sobre a relação, tanto para homens quanto para mulheres.

Esse acompanhamento pode favorecer a identificação, nomeação e reflexão sobre as anestesias relacionais de todos/as envolvidos/as. Precisamos contribuir para que as mulheres e homens possam voltar a sentir raiva, indignação, dor e a se horrorizarem tanto com os próprios atos agressivos ou do/a parceiro/a quanto com sua própria tolerância, permissividade e passividade (Ravazzola, 1997).

A intervenção pode ser um dos recursos para "desanestesiar" a percepção das pessoas em relação à violência. Elas podem voltar e/ou começar a enxergar os perigos e os riscos da violência para sua integridade física e mental. A reativação de sentimentos que estavam adormecidos pode ser fundamental para começarem a reagir novamente à violência. Essa reação constitui um passo importante para interromper e superar a violência.

A compreensão dos diversos fatores que contribuem para a instalação e perpetuação da impossibilidade ou dificuldade de refletir sobre a relação, é importante para romper com as outras condições de duplo-vínculo que estruturam a dinâmica conjugal marcada pela violência (Angelim, 2009; Angelim \& Diniz, 2010; Watzlawick et al., 1967/2007).

Grupos de mulheres podem auxiliá-las a questionarem a segunda condição do duplo-vínculo - o paradoxo entre o afeto prometido pelos parceiros e a violência praticada por eles (Angelim, 2009; Guimarães, 2009). Beiras e Cantera (2012) acreditam que grupos de homens têm grande potencial de ressocialização entre homens. O trabalho com homens pode ajudá-los a refletir, descobrir, atualizar e nomear novos significados e narrativas identitárias e relacionais. Esse trabalho pode, inclusive, ajudá-los a desvelar várias contradições e paradoxos entre as suas intenções de permanecer sem violência e o ato cometido.

Os grupos reflexivos para homens e mulheres são poderosos recursos terapêuticos, mesmo que não se configurem como psicoterapia. Eles favorecem a criação de uma rede de comunicações, de troca de experiências e de apoios sociais, que ajuda a romper a terceira condição de duplo- 
vínculo - eles geram oportunidades para homens e mulheres desafiarem mensagens culturalmente conflitivas e paradoxais, inclusive de valor de sobrevivência entre os cônjuges; e podem ajudar no reconhecimento de que ambos têm o direito de viver sem violência. Dessa forma, os grupos podem favorecer a superação do segundo e do primeiro critério de duplo-vínculo. Assim, aumentam a possibilidade de mulheres e homens realizarem mudanças que contribuam para superação e transformação da violência conjugal (Boyd-Franklin \& Franklin, 2003).

Uma análise detalhada das anestesias relacionais e dos critérios de duplo-vínculo carrega o potencial de revelar o quanto um relacionamento marcado pela violência conjugal pode estar alicerçado em padrões paradoxais, de difícil reconhecimento e superação. Essa análise deve ser feita à luz de uma perspectiva de gênero, no intuito de evitar "condicionar o tipo de relação afetiva entre agressor e vítima e naturalizar algumas das contradições vividas pelas mulheres" (Angelim \& Diniz, 2010, p. 403).

É importante desenvolver novas propostas metodológicas de pesquisa e intervenção para favorecer o empoderamento das mulheres e de homens em situação de violência. Um dos primeiros passos nesse sentido é a conscientização dos paradoxos existentes na relação. Essas propostas podem contribuir para que ambos percebam a tendência de minimizar, de justificar e até negar a própria experiência como violenta baseados em mitos sociais. Dessa forma, poderemos ter mais condições para que homens e mulheres realmente possam se libertar e transformar as relações sociais e conjugais.

Nesse contexto, torna-se fundamental entendermos o atual panorama das políticas, ações e intervenções com homens autores de violência. É importante compreender como essa população está sendo vista, percebida e atendida. Apresentamos um breve um panorama da atenção aos homens no próximo capítulo. 


\title{
Capítulo 3
}

Pesquisas, políticas e intervenções com homens autores de violência

\author{
Vou de mansinho, veja \\ Te amo, te odeio, mas mesmo assim quero você \\ Só você pra me ganhar com o olhar \\ Curtindo até me perco te dou direito de me achar \\ Briga, separa, quebra a cara e volta \\ Vê que sem o outro a vida é tão sem graça \\ (Música: Suíte 14 - Henrique e Diego, participação MC Guimê)
}

As pesquisas, políticas, ações e intervenções com homens envolvidos em dinâmica de violência conjugal têm sido alvo de diversas críticas. Existem, simultaneamente, muitos argumentos favoráveis à ideia de oferecer algum tipo de atenção a esses homens. Apresentamos, nesse capítulo, uma breve descrição do panorama internacional e nacional das intervenções com homens, em que trazemos um histórico e o contexto brasileiro atual. Mostramos os principais pontos da Lei Maria da Penha à respeito das masculinidades na situação da violência. Descrevemos as características dos programas de atenção aos homens no Brasil e suas perspectivas rumo a uma maior aproximação dos homens para compreender fatores que lhes aprisionam à violência conjugal, especialmente os processo sociais de construção de masculinidades que favorecem a naturalização da violência.

\section{Intervenção com homens: dimensão essencial para o enfrentamento da violência}

A ideia de intervir junto aos homens em situação de violência conjugal foi alvo de muitas críticas e, inicialmente, não foi bem aceita em vários países. Há uma grande tendência de surgir indignação, desejo de vingança e de punição com castigos a esses homens (Manita, 2008; PonceAntezana, 2012). Acreditamos que a indignação em relação à violência de homens contra mulheres seja uma reação adequada - o desejo de punição também. Já a ideia de vingança é perigosa e ineficaz - não se constrói reflexão e mudança com retaliações.

As críticas geralmente são feitas por alguns/mas profissionais que atuam apenas com mulheres vítimas de violência, autoridades e alguns/mas integrantes de movimentos feministas como meio de se posicionarem contra essas ações (Lima \& Büchele, 2011; Medrado et al., 2011). Os três conjuntos de críticas mais frequentes são referentes a:

- Limitação e precariedade de recursos econômicos e de profissionais;

- Não imposição de medidas punitivas em vários casos;

- Argumentos de que intervenções com homens não são efetivas (Lima \& Büchele, 2011; Ponce-Antezana, 2012).

As pessoas e instituições que defendem as intervenções com homens em situação de violência conjugal argumentam que essas ações não são respostas opostas ou concorrentes às 
intervenções com as mulheres. São intervenções complementares (Manita, 2008). A superação das críticas e dos preconceitos constitui um desafio importante para o fortalecimento e expansão das ações e intervenções com homens.

Essas intervenções possuem os mesmos objetivos: a interrupção ou redução da violência conjugal. Diante desse contexto, entendemos que as críticas à oferta de tais serviços são infundadas e merecem serem revistas. A implantação de programas de atenção aos homens autores de violências vai muito além do que uma mera disputa de recurso público. Esses programas inserem-se em uma perspectiva que questiona a ideia de apenas buscar a punição, uma vez que se sabe que ela sozinha não reduz a violência. Pesquisas mostram que esses programas ainda têm efeitos modestos, porém são positivos (Lima \& Büchele, 2011; Manita, 2008; Medrado et al., 2011).

A intervenção com homens visa proteger as mulheres vítimas e reduzir as elevadas taxas de reincidência. Objetiva ainda contribuir para diminuir os custos para as vítimas, familiares, assim como os custos médicos, jurídicos e sociais da violência conjugal. Além disso, tem como alvo os próprios homens ao buscar uma intervenção positiva a partir da problematização e proposta de revisão dos modelos de masculinidades, que são fortemente associados à agressividade em nossa sociedade. Essa intervenção faz parte de uma estratégia de atender às necessidades demandadas pela maioria dos casos de violência (Manita, 2008; Medrado et al., 2011).

Ponce-Antezana (2012) corrobora esses argumentos e faz uma lista dos principais pontos favoráveis para responder à pergunta “Por que realizar intervenções com homens?". Para esse pesquisador, as razões mais importantes para implementar tais programas são:

- As próprias mulheres pedem atendimentos para os seus parceiros;

- Buscar a responsabilização dos homens e a erradicação da violência;

- Muitas mulheres não se separam e/ou voltam a viver com os parceiros;

- Mesmo em casos de separação, a violência tende a se repetir com novos cônjuges;

- Romper a transmissão transgeracional da violência;

- Intervir apenas com as mulheres pode exacerbar a violência de gênero.

Muitas mulheres sentem a necessidade dos parceiros também participarem das intervenções. Esse pedido de atender o outro cônjuge também é feito por vários homens em processo de acompanhamento psicossocial. Ambos percebem os benefícios de uma intervenção com todas as pessoas envolvidas (Acosta et al., 2004; Aguiar, 2009; Araújo, 2012; Guimarães, 2009; Macedo, 2013). Ponce-Antezana (2012) reforça essa ideia ao defender a complementaridade das ações:

a transformação da identidade e da subjetividade de gênero das mulheres, quando não acompanhada de um mínimo de recursos de trabalho para transformar a masculinidade nos homens que praticam abusos, gerará um incremento ainda maior da distância subjetiva e social, e um estranhamento crítico entre as pessoas de gêneros 
diferentes, o que pode ter como efeito perverso a exacerbação da violência de gênero na convivência social que se pretende erradicar (Ponce-Antezana, 2012, p. 12).

As políticas, ações e intervenções em casos de violência conjugal centralizados somente nas mulheres vítimas e suas famílias têm se mostrado insuficientes na diminuição da alta incidência da violência conjugal (Toneli et al., 2008). Medrado (2009) e Medrado e Méllo (2008) citam trecho de material escrito por uma das maiores e mais respeitadas pesquisadoras feministas do Brasil, Heleieth Saffioti, em que ela também defende essa inclusão de homens. No texto, Saffioti afirma que:

As pessoas envolvidas na relação violenta devem ter o desejo de mudar. É por esta razão que não se acredita numa mudança radical de uma relação violenta, quando se trabalha exclusivamente com a vítima. Sofrendo esta algumas mudanças, enquanto a outra parte permanece o que sempre foi, mantendo seus habitus, a relação pode inclusive, tornar-se ainda mais violenta. Todos percebem que a vítima precisa de ajuda, mas poucos veem esta necessidade no agressor. As duas partes precisam de auxílio para promover uma verdadeira transformação da relação violenta (Saffioti, 2004, conforme citado por Medrado \& Mello, 2008, p. 81; Medrado, 2009, p. 23).

As recomendações de implantação de mais serviços de atenção aos homens são corroboradas por vários estudos e pesquisas (Aguiar, 2009; Araújo, 2012; Figueira, 2011; Guimarães, 2009; Lima \& Büchele, 2011; Macedo, 2013; Oliveira \& Gomes, 2011; Silveira et al., 2009; Siqueira, 2012). Esses estudos ressaltam a importância de ultrapassar resistências e incluir os homens na atenção à violência conjugal de modo a favorecer a construção de estratégias para a resolução efetiva do problema.

É importante buscar parcerias com serviços que atuam com mulheres para que a perspectiva de gênero seja efetivamente implementada no enfrentamento da violência (Lima \& Büchele, 2011). Nesse sentido, Beiras et al. (2012) afirmam que o trabalho com homens em conjunto com as mulheres é a alternativa mais eficaz na redução, contenção e prevenção da violência conjugal.

A soma dessas duas ações parciais e complementares, em conjunto a muitas outras estratégias, pode provocar verdadeiras revoluções rumo a uma maior equidade de gênero e, consequentemente, à diminuição da violência em nossa sociedade (Lima \& Büchele, 2011). A partir dessa perspectiva, Manita (2008) aposta e acredita que a articulação entre programas de atendimento a mulheres e homens será consensual no futuro.

Essa integração já está prevista em várias leis, convenções e instituições internacionais. A Lei 11.340/2006 - Lei Maria da Penha - LMP, por exemplo, garantiu uma legitimidade política para a discussão e implementação de ações que incluam os homens a partir da perspectiva de gênero. Essa lei trouxe relevante legitimidade para as ações voltadas aos homens, que não existia antes no Brasil. Tal legitimidade foi conferida especialmente por meio dos Artigos 35 e 45. Nesses artigos, a lei preconiza e recomenda a atenção aos homens autores de violência de gênero como 
sendo necessária ao enfrentamento da violência, especialmente a conjugal (Beiras, 2014; Beiras et al., 2012; Lima \& Büchele, 2011; Medrado, 2009; Medrado \& Méllo, 2008; Medrado et al., 2011).

No início da década de 1990, grandes conferências internacionais, incluindo as de Beijing e Cairo, sinalizaram a necessidade de incorporar os homens como alvos de políticas públicas para o enfrentamento da violência (Toneli et al., 2010). O Relatório da Secretaria Geral da Organização das Nações Unidas (ONU, 2006) corrobora e amplia essa ideia. A ONU compreende o trabalho com homens como uma das práticas promissoras no enfrentamento da violência contra a mulher. E vai mais além, ao afirmar que não se pode ter sucesso nessa área sem envolver os homens.

Manita (2008) também enfatiza a intervenção com homens como um elemento central para a redução efetiva da violência conjugal. A autora não vê tal intervenção como um componente adicional ou opcional, mas como dimensão essencial no combate à violência doméstica. Vários autores afirmam que essas intervenções têm o potencial de promover verdadeiras mudanças de perspectiva e de paradigma (Beiras et al., 2012; Medrado, 2009; Medrado \& Méllo, 2008).

Acreditamos que as críticas e os pontos favoráveis a respeito da ideia de oferecer políticas, ações e intervenções direcionadas aos homens são importantes para podermos entender criticamente o contexto de atenção aos homens no enfrentamento da violência conjugal no âmbito internacional e nacional. Essa concepção crítica favorece a compreensão dos avanços, retrocessos e desafios do cenário dessa atenção aos homens em vários países, inclusive no Brasil.

\section{Panorama internacional das intervenções com homens}

As intervenções com homens autores de violência conjugal estão ganhando destaque no cenário internacional. Os programas de intervenção estão se desenvolvendo e generalizando, especialmente nos últimos anos. Já estão presentes em diversos países dos cinco continentes (Manita, 2008; Rothman et al., 2003).

As primeiras experiências de intervenção com os homens começaram no fim da década de 1970 e início de 1980. Os pioneiros foram os Estados Unidos da América - EUA e o Canadá. Em 1977, uma comunidade de homens pró-feministas criou o Counseling \& Education to Stop Domestic Violence - EMERGE em Boston. Em 1981, foi desenvolvido o Domestic Abuse Intervention Project, em Duluth, Minnesota, que ficou conhecido como Modelo Duluth. Logo essas iniciativas se expandiram para o Canadá, que ao final da década de 1990 já contava com mais de 200 programas (Lima \& Büchele, 2011; Ponce-Antezana, 2012; Veloso \& Natividade, 2013).

Esses programas foram criados em instituições que já atuavam com mulheres. O objetivo foi complementar as intervenções, não foi substituir a atenção a elas. Cada vez mais esses programas passaram a atuar em conjunto com a justiça, no intuito de melhorar a segurança das vítimas e conseguir a responsabilização dos homens. Inicialmente, a maioria dos homens chegava a esses 
serviços por demanda voluntária, mas esse processo espontâneo foi dando lugar aos encaminhamentos realizados pelo sistema judicial, especialmente de homens condenados (Aguiar, 2009; Lima \& Büchele, 2011; Ponce-Antezana, 2012; Veloso \& Natividade, 2013).

O EMERGE e o Modelo Duluth se tornaram referências mundiais. A partir da década de 1980, esses modelos foram replicados, expandiram e se consolidaram no resto da América do Norte, Europa, Austrália, América Latina, África, Ásia e Oceania. Atualmente, os programas de atenção aos homens estão inseridos nos planos nacionais de combate à violência em diversos países: EUA, Canadá, Austrália, Nova Zelândia e na maioria dos países europeus (Lima \& Büchele, 2011; Manita, 2008; Ponce-Antezana, 2012).

O crescimento dos serviços voltados aos homens fez com que fossem criados padrões e protocolos, principalmente nos EUA e Canadá. Houve a preocupação em regular as atuações de modo a possibilitar a avaliação desses programas. No entanto, essa padronização foi alvo de muitas críticas, pois tendiam a limitar a criatividade e a possibilidade renovadora. Mesmo com essas críticas, esses modelos foram consolidados em vários países como uma alternativa adicional ao atendimento das mulheres (Graham-Kevan, 2007; Lima \& Büchele, 2011).

Os tratados e convenções internacionais de direitos humanos deram mais visibilidade ao fenômeno da violência contra a mulher e, como consequência, muitos ressaltaram a importância de incluir o trabalho com os homens. A atenção aos homens autores de violência teve um crescimento e maior destaque na última década, inclusive no contexto latino americano, europeu e nos EUA (Beiras \& Cantera, 2012; Lima \& Büchele, 2011; Silveira et al., 2009).

A visibilidade dessa problemática chamou a atenção das duas maiores instituições internacionais do mundo. A ONU e a OMS desenvolveram estudos e considerações importantes sobre a intervenção com os homens (ONU, 2006; Rothman et al., 2003; Veloso \& Natividade, 2013).

A Organização Mundial da Saúde - OMS realizou em 2003 um estudo com perspectiva global sobre a intervenção com homens autores de violência. Foram localizados 56 programas em 38 países nos cinco continentes classificados como Batterer Intervention Programs, que atuavam com homens. Foram localizados seis na América Latina (Rothman et al., 2003; Veloso \& Natividade, 2013).

Esse levantamento da OMS identificou que o objetivo principal dos programas é a interrupção dos comportamentos violentos dos homens e a segurança das mulheres. Verificou que esses programas têm como foco de intervenção três temas principais: a) a influência da dimensão de gênero na construção das masculinidades, com uma ênfase na relação entre homens e violência; b) a distinção entre relacionamentos íntimos saudáveis e não saudáveis; e c) as formas não violentas de 
resolução de conflitos. Assim, os objetivos desses programas eram buscar a responsabilização dos homens pela violência; a construção de relacionamentos mais equitativos com as mulheres; e o desenvolvimento emocional e a melhoria da autoestima desses homens (Lima \& Büchele, 2011; Rothman et al., 2003).

O relatório da Secretaria Geral da Organização das Nações Unidas - ONU (2006) sobre todas as formas de violência contra a mulher apontou a atenção aos homens como uma das práticas promissoras no enfrentamento dessa forma de violência. Esse relatório defendeu possíveis coalizões e programas direcionados a homens em comunidades, especialmente os que aumentam a conscientização de grupos de homens para a importância da temática, tais como militares, sindicatos, times esportivos e policiais. Indicou também a utilização de modelos positivos de socialização de homens que são opostos à violência contra mulheres.

$\mathrm{O}$ relatório da ONU trouxe várias campanhas bem-sucedidas nesse sentido. Cabe apontar especialmente a The White Ribbon Campaign (Campanha do Laço Branco), que encoraja homens e mulheres a se posicionarem contra a violência de gênero. Essa campanha teve início no Canadá em 1991 e se propagou para 47 países em distintos continentes: África, Ásia, Europa, América Latina e Pacífico. O principal objetivo foi/é a prevenção da violência por meio da estimulação à participação de homens para sensibilizar outros homens a nunca cometer, tolerar ou permanecer em relações violentas (ONU, 2006).

Outros exemplos apontados pelo relatório da ONU foram de iniciativas em Honduras e na Austrália. As campanhas com times de futebol de homens em Honduras ganharam destaque por promover o respeito aos direitos das mulheres em jogos desportivos populares no país. Antes e nos intervalos de jogos, atletas e torcidas mostravam cartazes contra a violência. Na Austrália, houve campanhas de prevenção nas comunidades com homens atletas jovens, de 21 a 29 anos de idade, com o slogan "violência contra mulher é contra todas as regras" (ONU, 2006).

A ONU defendeu a atenção aos homens como um dos meios de atingir "a igualdade entre os sexos e a autonomia das mulheres", que integra um dos oito Objetivos de Desenvolvimento do Milênio - ODM. Os ODM foram assinados por 189 países, inclusive o Brasil, que firmaram o compromisso de atingi-los até o ano de 2015 (PNUD Brasil/IPEA, 2014; ONU, 2000).

Lima e Büchele (2011) afirmam que mesmo com o avanço dos últimos anos, muitos países têm respondido somente à demanda de atender mulheres, mas poucos efetivaram realmente os programas de atenção aos homens autores de violência. Ao descreverem o panorama internacional sobre serviços de atendimento de homens autores de violência conjugal, Lima e Büchele defendem que há uma necessidade enorme de expansão para atender a demanda por esses serviços, especialmente no contexto latino-americano, incluindo o Brasil. Para conhecer um pouco mais da 
realidade de implantação desses serviços, vamos descrever brevemente os panoramas europeu, norte-americano e latino-americano, para depois discutir a situação brasileira.

\section{Panorama Europeu}

Hamilton et al. (2013) realizaram um levantamento de 54 programas que efetivamente atuam com homens em 19 países europeus. O estudo apontou a grande variedade de abordagens para lidar com a violência conjugal e a falta de estudos de qualidade para avaliar a efetividade desses programas.

Os programas cresceram tanto que foram criadas algumas associações internacionais para dar mais atenção aos homens autores de violência, especialmente na Europa. Algumas dessas associações são a britânica - chamada de "The National Association for Domestic Violence Perpetrator Programmes and Associated Support Services - RESPECT" e a rede da comunidade europeia nomeada “Work with Perpetrators of Domestic Violence in Europe" - cujas atividades são articuladas via projetos DAPHNE I, II e III (Graham-Kevan, 2007; Hamilton, Koehler \& Lösel, 2013; Manita, 2008; Veloso \& Natividade, 2013).

Em 2011, a Convenção de Istambul do Conselho da Europa Contra a Violência Doméstica Contra a Mulher recomendou a todos os Estados-Membros da Comissão Europeia que fomentassem intervenções com homens autores pela violência conjugal. A orientação foi para que a atenção contenha sanções legais e serviços de intervenção psicossocial com homens, sem prejuízo da intervenção com as mulheres vítimas. A Comissão Europeia criticou os países que ainda não possuíam esses programas integrados ao processo penal (Ávila et al., 2014).

Alguns promotores/as de justiça e pesquisadores/as brasileiros (Ávila et al., 2014) realizaram uma pesquisa para verificar quatro modelos europeus de enfrentamento à violência de gênero. Os quatro países estudados foram Espanha, Portugal, França e Inglaterra, justamente por terem muita influência junto ao contexto brasileiro. Os/as autores/as verificaram algumas convergências entre os sistemas jurídicos estrangeiros pesquisados, especialmente pelo tratamento da violência conjugal como uma forma diferenciada da criminalidade comum. Eles/as constataram que na Europa foi instituída a prioridade de intervenção do Estado por meio de uma resposta efetiva, com destaque para as Medidas Protetivas de Urgência - MPU. O estudo destacou também a instrumentalização da Justiça europeia para a responsabilização nos casos de violência psicológica e agressões físicas que não deixam marcas.

Espanha, Portugal, França e Inglaterra admitem a intervenção psicossocial aos homens autores como uma estratégia de responsabilização e de proteção à mulher, conforme previsão do artigo 16.1 da Convenção de Istambul. Além disso, atualmente, os movimentos feministas de Portugal e da França não consideram a suspensão do processo para encaminhamento como uma 
banalização da resposta penal, mas sim como um instrumento de intervenção mais eficiente (Ávila et al., 2014).

Estudos e ações anteriores corroboraram esses avanços. No contexto espanhol, em 2004 foi criada a Lei Orgânica de Medidas de Proteção Integral contra a Violência de Gênero. Essa legislação espanhola influenciou diretamente a elaboração da LMP no Brasil. Apesar de ter uma visão predominante de criminalização do "agressor", a lei espanhola considerou a importância de dar atenção aos homens (Beiras et al., 2012). Manita (2008) afirma que Portugal ficou temporariamente atrasado em relação aos outros países europeus. Os primeiros programas começaram apenas no fim da década de 1990, mesmo sob muita desconfiança de instituições de apoio a vítimas e de alguns segmentos dos movimentos feministas naquele momento. No entanto, em 2005 houve a integração dos programas de atenção aos homens no Plano Nacional de Luta contra a Violência Doméstica de Portugal. Cabe ressaltar, entretanto, que a oferta desses programas ainda é extremamente inferior às demandas em Portugal.

Graham-Kevan (2007) e Hamilton et al. (2013) chamam a atenção para o perigo de muitos programas europeus terem simplesmente importado os modelos americanos sem muita contextualização. Ressaltam, especialmente, a importação dos protocolos de algumas correntes feministas que conceitualizam os homens apenas como agressores, sem abranger toda a complexidade do fenômeno e sem levar em conta a heterogeneidade de posturas e comportamentos entre os homens autores de violência. Os dois estudos sugerem que os países europeus desenvolvam seus próprios programas fundamentados na literatura acadêmica e nas práticas baseadas em evidência.

\section{EUA e América Latina}

Toneli et al. $(2008,2010)$ realizaram importante estudo sobre os programas de atendimentos aos homens nos EUA e na América Latina. Eles/as visitaram programas no México, Peru, Argentina, Honduras, Nicarágua, Brasil e EUA. A escolha dos países para a pesquisa foi devido à tradição consolidada desse tipo de trabalho. Tomando por base esses estudos, vamos fazer inicialmente uma breve contextualização dos programas e modelos implementados em outros países, para depois descrever a realidade brasileira.

O estudo de Toneli et al. $(2008,2010)$ verificou que nos EUA predominam programas que adotam o referencial cognitivo-comportamental e o modelo psicoeducativo. Os programas são baseados no EMERGE, estratégia/ação que se afasta significativamente do movimento feminista. Eles têm preferência por terapias breves, com predominância de psicoterapias comportamentais e de técnicas de modificação de comportamento. O estudo também relatou a experiência do Massachusetts Alliance of Portuguese Speakers - MAPS, uma OnG que atende homens em Língua 
Portuguesa nos moldes da EMERGE. O MAPS realiza diversos trabalhos e atividades sociais. Para Scott, King, McGinn e Hosseini (2011), houve grande desenvolvimento e aumento nos programas de intervenção com homens nos EUA.

Gondolf (2011) realizou uma importante meta-análise dos estudos americanos sobre os programas de intervenção com homens autores de violência. Ele confirma que houve uma diversificação dos tipos de programas para homens nos EUA nos últimos anos. Muitas alternativas foram criadas, incluindo intervenções psicodinâmicas breves e focais, técnicas motivacionais para mudanças, aconselhamentos especializados para homens afro-americanos e intervenção para casais com violência conjugal mútua. No entanto, continua o predomínio de intervenções pautadas em perspectivas cognitivo-comportamentais.

A avaliação da efetividade dos programas e ações dirigidos aos homens merece atenção. Embora a pesquisa de Gondolf (2011) estimule a ampliação desses programas, ela também aponta que essas inovações necessitam de avaliação dos resultados baseados em evidência. Poucas pesquisas avaliam a efetividade dos programas.

Um estudo de revisão europeu mostrou que dentre 10.446 títulos pesquisados sobre intervenção com homens, apenas 12 trabalhos avaliaram os resultados de ações voltadas para essa população de maneira sistemática (Akoensi, Koehler, Lösel \& Humphreys, 2013). Em importante trabalho de meta-análise, Feder e Wilson (2005) confirmam que os programas para homens autores já estão bem estabelecidos nos EUA, mas eles também ressaltam a necessidade de mais estudos para confirmar a eficácia das intervenções, pois os resultados dos estudos ainda são contraditórios.

Os programas latino-americanos possuem muitas semelhanças entre si, especialmente por compartilharem o fato de serem países em desenvolvimento e por haver maior proximidade entre suas situações políticas e sociais, quase todos têm como base as causas feministas e assumem um olhar sociopolítico para o fenômeno da violência conjugal. Os serviços desses países ressaltam as relações de poder inerentes às relações de gênero e as suas intervenções são mais reflexivas e buscam mudanças subjetivas (Toneli et al., 2008).

A primeira experiência da América Latina de trabalho com homens foi implementada no México em 1995 pelo Colectivo Hombres por Relaciones Igualitarias - CORIAC. O trabalho foi elaborado com base na experiência dos EUA e tem como principal atividade o Programa Hombres Renunciando a Su Violencia - PHRSV, com perspectiva reeducativa e com ênfase em aspectos sociais ao invés de terapêuticos, por ter mais afinidade com os movimentos feministas (Toneli et al., 2008, 2010).

O Peru iniciou a intervenção com os homens em 2004, influenciado pelo intercambio com a experiência mexicana. O PHRSV foi implantado em uma Universidade em Lima e em uma 
instituição eclesiástica em Piura. No Peru e no México, a única forma de chegar a esses serviços é por demanda voluntária. Os dois motivos principais que levam a essa inserção voluntária são o fato de o sistema judicial ainda não assegurar a presença dos homens e o modelo de intervenção proposto requerer o interesse deles (Toneli et al., 2008, 2010).

$\mathrm{Na}$ Argentina foram visitados dois programas, um em Buenos Aires e outro em Córdoba. Lá predomina a intervenção em consultórios com referencial ecológico e sistêmico, com foco terapêutico e preventivo. Os serviços também ressaltam as relações de poder e relações de gênero nas intervenções. A Argentina se assemelha aos Estados Unidos quanto ao fato da forma principal de chegada dos homens ser por sentença judicial. Contudo, nos EUA os usuários podem ser presos se não participarem ou obrigados a repetir o acompanhamento, pois há uma grande coalizão entre a justiça e esses serviços. Na Argentina, não há punição se o homem não aderir, mesmo assim, há uma quantidade significativa de homens que buscam voluntariamente o atendimento nesses dois países (Feder \& Wilson, 2005; Toneli et al., 2008, 2010).

Em Honduras foi localizado o único programa integralmente governamental na América Latina naquele momento. O serviço realiza grupo de homens encaminhados pela Justiça. Nicarágua tem quatro OnGs, todos os serviços estão localizados na capital Manágua e possuem foco na capacitação e prevenção (Toneli et al., 2008, 2010).

A grande maioria dos serviços dirigidos aos homens na América Latina é conduzida por ONGs, universidades ou instituições religiosas. As formas predominantes de encaminhamentos dos homens foram por duas maneiras: através da Justiça ou por demanda voluntária (Toneli et al., 2008). O estudo de Toneli et al. (2010) apontou que a politização da atenção aos homens é primordial e representa grande avanço por parte dos programas latino-americanos. Eles têm como base as demandas feministas e de mudanças sociais para abrir caminhos para o fim das desigualdades de gênero na sociedade.

Apesar desse avanço, o contexto das intervenções latino-americanas ainda é marcado por uma visão curativa e com intensa criminalização da violência. Toneli et al. (2010) apontaram que esses países enfrentam muitas resistências, especialmente por muitos governos e por parte dos movimentos feministas, que ainda entendem esses programas como uma disputa de financiamento e de recursos. Essas instituições contrárias compreendem esses serviços como uma forma de não dar atenção às mulheres e como desvio de esforços, de verbas e de pessoal para o trabalho com os homens.

Muitos países não conseguiram enxergar ainda que atuar com homens é trabalhar para as mulheres, pois o investimento nessas atividades abarca melhor a complexidade das situações de violência ao ampliar e trabalhar com todos os envolvidos (Toneli et al., 2008, 2010). O trabalho 
conjunto com mulheres e homens é valorizado por esses/as pesquisadores/as como medida mais eficaz e completa.

A pesquisa de Toneli e colaboradores $(2008,2010)$ demonstrou que os programas de atenção a homens que cometem violência conjugal ainda é uma experiência recente no campo do gênero, mas mesmo assim, já tem grande importância social. Essas ações em conjunto com muitas outras podem provocar mudanças significativas e resultar em maior equidade de gênero. Há uma grande e evidente necessidade de implementação de mais programas dedicados à atenção aos homens. No entanto, dentro da realidade latino-americana ficou constatado que apenas recentemente alguns países começaram a investir e a lidar com a replicação ou multiplicação desses serviços (Toneli et al., 2008). Ainda temos muito que avançar nesse sentido, inclusive no Brasil.

\section{Panorama nacional}

É preciso reconhecer o histórico de luta do movimento feminista brasileiro para contextualizar o panorama nacional de intervenção com homens. Esse movimento deu visibilidade à violência contra mulheres e realizou diversas manifestações a partir da década de 1970, especialmente para denunciar os homicídios, assim como as práticas misóginas e discriminatórias da justiça (Bandeira, 2009; Magalhães, 2011; Porto \& Costa, 2010; Silveira et al., 2009; Yamamoto $\&$ Colares, 2015).

Essas manifestações e reivindicações ganharam força com a inclusão da violência contra a mulher na arena dos direitos humanos e da saúde. O Brasil participou de diversas conferências e convenções no âmbito das Nações Unidas entre as décadas de 1980 e 1990, com destaque para o Committee on the Elimination of Discrimination against Women - CEDAW em 1984, a Convenção de Belém do Pará em 1995 e a Conferência Mundial da Mulher em 1995 (Silveira et al., 2009). Nesse contexto de atuação, o Brasil assinou diversos documentos oficiais. Muitos deles possuem valor constitucional e de aplicação imediata no país. Vale ressaltar que as convenções têm valor vinculante e passam a ter força de lei para os países que as assinam (Brauner \& Carlos, 2004; Carreira \& Pandjiarjian, 2003; Magalhães, 2011; Pandjiarjian, 2002).

\section{Histórico e contexto brasileiro atual}

A violência contra a mulher conquistou mais visibilidade a partir da publicação da Lei n. ${ }^{\circ}$ 11.340/2006 - intitulada Lei Maria da Penha em 2006. Recentemente, diversas ações começaram a chamar atenção para o lugar dos homens nas políticas públicas brasileiras dessa área. Esse novo lugar só teve espaço privilegiado em duas referências localizadas antes da promulgação da referida lei. As intervenções com homens foram mencionadas pontualmente em uma publicação de 2001 do Ministério da Saúde intitulada “Violência Intrafamiliar: Orientações para a Prática em Serviço”, 
que recomendou a promoção de grupos de homens como forma alternativa de resolução de conflitos e a reeducação de "agressores" (Lima \& Büchele, 2011; Silveira et al., 2009).

As outras menções foram no I e no II Plano Nacional de Políticas para as Mulheres homologados em 2004 e em 2008 (esse último, após a promulgação da LMP). Esses planos foram além da punição e responsabilização dos "agressores" e preconizaram a criação dos centros de educação e reabilitação. Até então, todas as metas, recomendações e prioridades foram quase que exclusivamente direcionadas às mulheres (Brasil/SPM, 2004, 2008; Lima \& Büchele, 2011; Silveira et al., 2009).

As duas exceções a essas metas foram o apoio à Campanha do Laço Branco e ao projeto Siga Bem Mulher, destinada a caminhoneiros/as. A inclusão dos homens nas políticas públicas brasileiras sobre violência conjugal ainda permanece incipiente. São pouquíssimos os números sobre a efetividade das ações (Lima \& Büchele, 2011).

O fato é que Brasil iniciou os programas de intervenção com homens autores de violência na segunda metade da década de 1990. Nesse momento, muitos outros países latino-americanos já haviam consolidado os seus programas direcionados aos homens. O nosso país começou com um pequeno número de ações, geralmente realizados por OnGs. Uma ação pioneira foi desenvolvida pelo Instituto de Pesquisas Sistêmicas e Desenvolvimento de Redes Sociais - Instituto NOOS em 1999 (Beiras, 2014; Lima \& Büchele, 2011).

OnGs como o Instituto Papai, o Instituto Promundo e a ECOS: Comunicação em Sexualidade foram precursoras no trabalho preventivo e interventivo com a população jovem e adolescente, ao utilizarem abordagens pautadas nas questões de gênero e masculinidades. Essas instituições realizaram vários estudos, intervenções sociais e mobilizações políticas com olhar especial para o público masculino. Em conjunto com os movimentos feministas, foram e são importantes instâncias de atuação para sensibilizar a sociedade para ações em saúde voltadas à população jovem e masculina. Essas OnGs têm como um dos principais objetivos a conquista da equidade de gênero e o bem-estar de homens, mulheres e crianças (Lima \& Büchele, 2011).

Outra iniciativa importante foi a criação da Rede Brasileira de Pesquisas sobre Violência, Saúde, Gênero e Masculinidades - VISAGEM. Ela é composta por núcleos de pesquisa de universidades públicas das cinco regiões do Brasil. Uma das maiores ações realizadas no Brasil foi a Campanha do Laço Branco, encampada pela VISAGEM e pela Rede de Homens pela Equidade de Gênero - RHEG (Beiras et al., 2012; Lima \& Büchele, 2011; Medrado, 2009).

Essa campanha é baseada no modelo canadense para envolver homens pelo fim da violência contra mulher. Tem como objetivos prioritários o diálogo com homens com o objetivo de reinscrever e redescrever as masculinidades e a transformação das práticas, símbolos, instituições e 
cultura para alcançar novas masculinidades com estilos de vida mais saudáveis e tipos masculinos mais positivos. Essa campanha abriu espaço para a criação da Lei 11.489/07, intitulada como "Lei do Laço Branco", que instituiu e agregou ao calendário brasileiro a data de seis de dezembro como o Dia Nacional de Mobilização dos Homens pelo fim da Violência contra as Mulheres (Beiras et al., 2012; Medrado, 2009; Oliveira \& Gomes, 2011).

Esse percurso visa deixar clara a construção da violência contra mulher como problema social e de saúde. Nesse contexto, a inclusão de ações voltadas para os homens é marcada por avanços e retrocessos (Silveira, Medrado \& Rodrigues, 2009). Silveira, Medrado e Rodrigues (2009), pesquisadores/as do campo dos estudos de gênero, desenvolveram um trabalho que teve o objetivo de mapear os serviços voltados para os homens autores de violência em Recife, mas constataram a inexistência de tais serviços.

Os serviços destinados aos homens autores de violência ainda são incipientes no Brasil (Beiras, 2014; Veloso \& Natividade, 2013). Mesmo passada quase uma década da promulgação da Lei Maria da Penha e de vários/as pesquisadores/as apontarem a importância da atenção a esse público, ainda temos poucos programas de atenção aos homens. Beiras ressalta a necessidade da criação de mais programas para contemplar a demanda por atenção voltada à população masculina em todo território nacional.

Diante dessa escassez de ações e da necessidade de conhecer melhor a realidade dos serviços voltados para os homens, o Instituto NOOS (Beiras, 2014) realizou um relevante mapeamento nacional. Foram encontrados apenas 25 programas ativos no Brasil que realizam atendimento a homens autores de violência. Beiras entrou em contato com todos eles, e dentre os 19 serviços que retornaram e participaram do estudo, a maioria (12) concentra-se no Sudeste, seguido pelo Centro Oeste e Sul com 3 serviços cada, Norte com apenas um. O Nordeste não teve instituição/serviço participante.

A maioria desses programas começou ou reformulou suas atividades para abranger os homens entre 2003 e 2011, grande parte impulsionado pela Lei Maria da Penha - LMP, promulgada e homologada a partir de 2006. O primeiro serviço a atender os homens foi o do Instituto NOOS, no Rio de Janeiro, que começou suas atividades em 1999, seguido pelo Núcleo de Atenção à Violência - NAV no Rio de Janeiro e pelo Pró-Mulher, Família e Cidadania em São Paulo (Beiras, 2014; Lima \& Büchele, 2011).

Inicialmente, muitos serviços eram voltados às mulheres ou famílias, e depois foram adaptados para também atender os homens. A maioria dos serviços que inicialmente começou a atender os homens era OnGs. Atualmente, as OnGs correspondem a aproximadamente $21 \%$ e as instituições governamentais a $64 \%$ do total de serviços oferecidos. Grande parte é composta por 
serviços da esfera executiva ou serviços psicossociais do poder judiciário (Beiras, 2014). Reconhecemos a importância da atuação de OnGs, mas defendemos a implantação desses serviços como políticas públicas do Estado.

Duas instituições estatais pioneiras no Brasil no atendimento a homens autores de violência são o SERAV e o NAFAVD. O Serviço de Assessoramento aos Juízos Criminais - SERAV é um serviço do Tribunal de Justiça do Distrito Federal e dos Territórios - TJDFT e atende homens e mulheres em situação de violência doméstica desde o ano de 2000 (Ghesti-Galvão \& Roque, 2010; Lobão, Resende \& Roque, 2012; Roque, Moura \& Ghesti, 2006). O Núcleo de Atendimento às Famílias e Autores de Violência Doméstica - NAFAVD pertence à Secretaria de Política para Mulheres, Igualdade Racial e Direitos Humanos - SEMIDF do Governo do Distrito Federal e faz intervenção com homens desde 2003 (Aguiar, 2009; Aguiar \& Diniz, 2008; Beiras, 2014; Figueira, 2011).

O mapeamento realizado pelo Instituto NOOS aponta para a necessidade de incluir mais espaços de cuidado e atenção aos homens autores de violência conjugal. A discussão sobre as masculinidades é vista como um importante caminho para problematizar a desigualdade de gênero e para a superação da violência. Beiras (2014) ressaltou que o estudo realizado não teve o intuito de ser exaustivo e contemplar todos os serviços; alguns não responderam o questionário e pode ser que outros não tenham sido localizados. O pesquisador reforçou a relevância de serem realizados mais estudos no sentido de identificar as características e ações desses serviços, inclusive de ampliar esse mapeamento. O trabalho de Beiras foi importante para revelar um pouco da realidade nacional dos atendimentos aos homens autores de violência. Apesar da evolução em vários aspectos, o relatório indica que esses programas ainda precisam avançar na metodologia, troca de experiências, na avaliação dos programas e na integração com a rede desses serviços.

O contexto brasileiro atual ainda é marcado por pouquíssimos estudos, pesquisas e ações com homens autores de violência, apesar dos avanços citados acima. O atendimento aos homens ainda não se configura como política pública, mas há uma tendência cada vez mais emergente de caminhar nessa direção (Lima \& Büchele, 2011). Apesar de a Política de Atenção Integral à Saúde do Homem - PNAISH ser considerada um marco para a discussão da saúde masculina (Separavich \& Canesqui, 2013), não houve ainda uma integração entre a PNAISH e as políticas de enfrentamento à violência conjugal, inclusive a Lei Maria Penha - LMP (Beiras et al., 2012). Fica evidente a presença de um paradoxo: apesar da maioria dos estudos sobre masculinidades e violência serem da área da saúde, ainda não se fez uma integração efetiva com as políticas no campo da saúde com os planos nacionais de enfrentamento à violência e a LMP. 
Beiras et al. (2012) enfatizam que as leis e as políticas públicas sobre homens em situação de violência conjugal merecem reflexão no momento de aplicação e análise, pois oferecem dificuldades, armadilhas e lacunas. As leis penais sobre violência são polarizadas, dicotômicas e excludentes. Dessa forma, contribuem pouco para o desafio de compreensão da complexidade dessas inter-relações. Isso não significa negar que existam vítimas. É evidente que as mulheres sofrem maiores danos, mas urge refletir sobre a série de proteções judiciárias que reforçam e fixam a posição de fragilidade das mulheres e apenas rotulam os homens como criminosos (Beiras et al., 2012).

Não se pode judicializar as relações sociais. A violência é um problema social e não será resolvido apenas com lei. A lei é fundamental, mas deve ser um dos recursos disponíveis. Devemos (re)pensar outras formas de acesso à justiça, democratização e cidadania (Beiras et al., 2012). Nesse sentido, ampliar a visão sobre a Lei Maria da Penha é fundamental, especialmente no que tange a atenção aos homens.

\section{Lei Maria da Penha e masculinidades: como a lei enxerga os homens}

Em 2012, a Lei Maria da Penha - LMP foi classificada como a terceira melhor do mundo pela Organização das Nações Unidas. A LMP ficou atrás apenas das legislações espanhola e chilena. A LMP trouxe indiscutíveis avanços, principalmente por ter definido a violência contra mulher como crime específico, por ter alterado o cotidiano das instituições, estimulado mudanças simbólicas por meio de debates públicos e ampliado o interesse pelo tema (Azevedo, 2008; CFEMEA, 2009; Magalhães, 2011; Martins, Cerqueira \& Matos, 2015; Medrado, 2009; IPEA, 2014; Yamamoto \& Colares, 2015).

A LMP tem um foco maior na violência conjugal (Medrado, 2009) e inovou por trazer uma recomendação explícita para atenção aos homens em situação de violência no contexto brasileiro atual (Toneli et al., 2008). A lei conferiu legitimidade política sem precedentes na história brasileira para a discussão e implementação de ações voltadas também aos homens em seus artigos 35 e 45 . O artigo 35 tratou dos Centros de Educação e de Reabilitação e o artigo 45 dos Programas de Recuperação e Reeducação, em que o juiz pode determinar o comparecimento obrigatório do “agressor” a esses programas. Apesar desses avanços, a LMP não discorre sobre a estrutura e organização dos centros e dos programas (Lima \& Büchele, 2011; Lopes \& Leite, 2013; Medrado, 2009; Medrado \& Méllo, 2008).

Dois anos após a promulgação da LMP, a Secretaria Especial de Política para as Mulheres da Presidência da República - SPM realizou um workshop para discutir com vários organismos governamentais e da sociedade civil como orientar a criação desses programas previstos na lei. Em 2008, a SPM lançou as Diretrizes para Implementação dos Serviços de Responsabilização $e$ 
Educação dos Agressores como uma referência de sistematização dos resultados desse workshop (Brasil/SPM, 2008; Lopes \& Leite, 2013).

Essas diretrizes defendem a criação dos Centros de Educação e de Reabilitação para Agressores conforme o Artigo 35 da LMP. Esses centros têm objetivos semelhantes aos centros de referência de assistência social, como os CRAMs, CEAMs e CREAS. O intuito é oferecer uma atenção mais ampla e preventiva aos homens. As diretrizes enfatizam mais a implantação dos Programas de Recuperação e Reeducação dos Agressores baseados no Artigo 45, de cunho obrigatório e educativo. Esses Serviços de Responsabilização e Educação dos Agressores - SREA são os equipamentos responsáveis pelo acompanhamento de penas e das decisões judiciais, vinculados diretamente ao sistema de justiça. Os centros têm o propósito mais preventivo e os SREA com foco de intervenção secundária e/ou terciária (Brasil/SPM, 2008).

As práticas nos SREA seriam de cunhos pedagógicos e educativos, sendo proibido tratamentos, mediações e terapias nesses espaços. Além disso, os SREA não podem funcionar nos serviços especializados de atendimento à mulher. Por último, as diretrizes preveem que a SPM seria responsável pelas diretrizes gerais, mas o financiamento das ações ficaria a cargo do Departamento Penitenciário Nacional do Ministério da Justiça - DEPEN/MJ (Brasil/SPM, 2008).

O Conselho Nacional de Justiça - CNJ (2010) lançou no ano de 2010 o Manual de Rotinas e Estruturação dos Juizados de Violência Doméstica e Familiar Contra a Mulher em consonância com essas diretrizes. O CNJ prevê como atribuição da equipe multidisciplinar as intervenções com o "agressor/réu". Esse Conselho regulamenta os SREAs como vinculados ao sistema de justiça do Poder Judiciário, das Secretarias de Justiça Estaduais e/ou Municipais.

Essas diretrizes, no entanto, ainda não têm grande repercussão e nem são bem conhecidas no meio científico e no contexto das políticas públicas. Os centros e os SREA ainda não foram efetivamente implantados. Apesar da previsão legal e da indicação da SPM e do CNJ, concordamos com Lopes e Leite (2013), que afirmam que:

na prática, há ainda pouco conhecimento e investimento para a constituição de atividades educativas com os homens autores de violência, com experiências pontuais desenvolvidas mais em função da sensibilidade de alguns profissionais do sistema de justiça ou instituições da sociedade civil que a partir de um indicador sistêmico dos governos e órgãos de justiça (Lopes \& Leite, 2013, p. 36).

É preciso ter um olhar crítico sobre a LMP. O intuito não é ir contra essa lei fundamental ao enfrentamento da violência. Acreditamos, no entanto, que para que ela tenha mais sustentação política e para garantir que seja aplicada de forma mais efetiva, urge uma ampliação e revisão de algumas propostas simplistas, que resumem a atuação da lei à punição dos homens, especialmente por meio da prisão (Azevedo, 2008; Medrado, 2009). 


\section{Críticas à implantação da Lei Maria da Penha em relação aos homens}

O pouco interesse governamental nas ações e programas com homens autores compõe um dos aspectos negativos do contexto atual de aplicação da Lei Maria da Penha (Medrado, 2009; Medrado \& Méllo, 2008). Uma das principais críticas sobre a LMP recai sobre a questão da prevalência da visão hegemônica da violência conjugal nos termos da lei. A mulher é descrita de várias formas na lei: "mulher”, "mulher em situação de violência doméstica e familiar", "vítima” ou "ofendidas". Os homens são referidos exclusivamente como "agressores". O uso desse termo reforça um estigma e prioriza o caráter punitivo da LMP (Lima \& Büchele, 2011).

Medrado (2009) e Medrado e Méllo (2008) confirmam essa priorização da punição pela Lei Maria da Penha. Eles analisaram o que o texto da lei diz sobre os homens. A Seção II - referente às Medidas Protetivas de Urgência que Obrigam o Agressor, bem como as ações previstas para o “agressor" destacadas nos artigos 20, 35 e 45 reforçam o aspecto punitivo. O Artigo 20 prevê a prisão preventiva do "agressor". Nós concordamos com as críticas acima, mas é preciso tomar cuidado, pois em muitos casos é a prisão preventiva do homem autor de violência que garante que a mulher permaneça viva. Não somos contra o aspecto punitivo da lei em alguns casos. Somos contra a generalização da punição para todos os homens.

Homens ocupam, na maioria dos casos, o lugar de autoria das agressões conjugais - não podemos diminuir/subestimar o impacto disso. O contraponto é desfazer/desconstruir esses lugares sociais de gênero, ou seja, problematizar o sistema sexo-gênero construído ao longo da história em função de interesses políticos, sociais e do mercado de trabalho. A Lei pode ser um dos mecanismos para favorecer essa ressignificação social. No entanto, para haver essa ampliação da LMP, precisamos analisar como a lei descreve os homens autores de violência.

A análise de conteúdo/textual da LMP evidencia que não consta em nenhum momento a palavra "homem". A palavra "mulher" ou "mulheres" aparece 60 vezes. Os termos "agressor" e “ofendida" têm 19 e 34 ocorrências, respectivamente (Medrado, 2009; Medrado \& Méllo, 2008).

Beiras et al. (2012) fazem uma síntese dos pontos desfavoráveis da LMP e da legislação espanhola, que serviu de inspiração à lei brasileira (Beiras et al., 2012). Os autores apontam como aspectos desfavoráveis: a) a excessiva vitimização da mulher e criminalização do homem; b) a discussão sobre a constitucionalidade por possivelmente serem leis anti-isonômicas, ponto que já foi pacificado no Brasil pelo Supremo Tribunal Federal - STF, a LMP foi declarada constitucional; c) a sua excessiva penalização e criminalização e o protagonismo jurídico diante de lógica dicotômica, positivista e criminológica. As delegacias comuns e especializadas constituem as únicas portas de entrada para a rede de atendimento (Silveira et al., 2009). 
A LMP não faz alusão explícita a trabalhos de promoção à saúde e à equidade de gênero com a população masculina. É preciso implementar ações para incluir os homens, inclusive em ações preventivas, intervenções psicoeducativas e/ou terapêuticas não compulsórias como ações complementares às sanções jurídicas (Beiras et al., 2012; Medrado, 2009; Medrado \& Méllo, 2008).

Ávila et al. (2014) corroboram essas ideias ao se basearem na criminologia crítica para apontar a falência de sistemas que se estruturem apenas em ações punitivas. Esses/as autores/as afirmam que vários segmentos do movimento feminista perceberam que o viés exclusivamente punitivista não é suficiente para lidar com a questão.

É necessário criar e ampliar espaços de solução dialógica para a resignificação das relações de gênero, por parte de mulheres e de homens. A intervenção psicossocial atende de forma mais satisfatória aos propósitos que deveriam ser atingidos pela resposta penal tradicional em muitos casos. Machado (2014) reforça essa necessidade de responsabilização antecipada de alguns homens, mediante acompanhamentos psicossociais e outras medidas alternativas.

Ávila et al. (2014) ressaltam que defender outras formas de atuação não é ser a favor do mito de que "homens que agridem mulheres não precisam de punição, precisam de tratamento". A punição é fundamental em diversos casos, mas não pode ser a única opção, como ainda prioritariamente acontece no Brasil. Concordamos com esses autores, ao defendermos que a aplicação da punição e/ou a intervenção psicossocial dependem de cada caso - é preciso estarmos atentos aos danos e vieses que podem estar presentes em qualquer tipo de generalização e não minimizar o risco e a gravidade da violência.

Ávila et al. (2014) afirmam que apesar de muitos autores defenderem a ampliação das alternativas para lidar com os homens, o sistema brasileiro caminha para a institucionalização de todos os conflitos em um processo penal. No Brasil, propagou-se a crença de que a suspensão condicional do processo seria sinônimo de banalização da resposta do Estado. Esse caminho adotado vai contra a tendência de todos os países europeus estudados por esses/as pesquisadores/as.

Cabe apontar que alguns projetos de intervenção com homens em fases preliminares do processo estão sendo aplicados no Brasil. Essa prática relativiza a proibição de acordos processuais/suspensão condicional do processo sinalizados pelo STF no julgamento da ADIN 4424. Esses projetos têm como base jurídica alguns instrumentos como as Medidas Protetivas de Urgência ou outros meios cautelares alternativos, mas não estão institucionalizadas na lei e podem ter pouca efetividade e estabilidade.

Urge, portanto, uma reforma legislativa para fortalecer e ampliar as ações com homens de forma a irem além da punição e serem mais efetivas (Ávila et al., 2014). Esses/as pesquisadores/as 
recomendam que o Brasil siga os passos adotados em alguns países europeus, como é o caso da Espanha, Portugal, França e Inglaterra, nesse sentido sinalizam que:

a relevância de que, também no Brasil, a intervenção psicossocial sobre o agressor passe a ser perspectivada como um dos elementos de uma política de enfrentamento à violência doméstica contra a mulher e não como um mero adendo de responsabilidade do sistema penitenciário (Ávila et al., 2014, p. 389).

Apesar das importantes críticas elencadas acima, vários estudos enumeram diversos aspectos positivos da LMP. Um desses aspectos está relacionado especificamente com a previsão da lei sobre a necessidade de implementar ações que possam incluir os homens a partir de uma perspectiva de gênero (Medrado, 2009; Medrado \& Méllo, 2008). Beiras et al. (2014) ressaltam que os pontos mais elogiados na LMP e na lei espanhola são a prioridade dada para alcançar o equilíbrio nas relações, para eliminar as desigualdades entre homens e mulheres, para oferecer a possibilidade de mais acesso à justiça e a garantia de proteção para mulheres, bem como a previsão de Medidas Protetivas de Urgência - MPU.

A Lei Maria da Penha ainda está em processo de implementação (Lopes \& Leite, 2013; Medrado et al., 2011) e vários questionamentos sobre os seus princípios e sua aplicabilidade ainda estão em discussão. As reflexões e críticas apresentadas não são feitas com a intenção de minimizar sua relevância, mas sim com o intuito de potencializar seus efeitos (Medrado \& Méllo, 2008).

A crítica à Lei não deve ser vista em momento algum como meio de colocá-la a favor dos homens e contra as mulheres, nem para prever a punição das mulheres em relação aos seus parceiros. Existem outros dispositivos legais para isso, tais como a Lei 9.099/1995. A LMP faz parte de políticas afirmativas de proteção às mulheres diante da histórica e gritante desigualdade de gênero em nossa sociedade.

A Lei Maria da Penha pode, no entanto, ser ampliada para dar mais atenção aos homens autores de violência e aos homens em geral de forma preventiva. Beiras et al. (2012) afirmam que para a ampliação de seu alcance e potencialidade torna-se necessário inserir algumas dimensões em relação ao atendimento oferecido aos homens em níveis micro e macro:

- Prevenção objetiva com a população masculina;

- Criação dos centros de atendimento aos homens nos termos do artigo 35;

- Abrir porta de entrada nos serviços de saúde;

- Incluir a lógica do cuidado e da integralidade da saúde para os homens;

- Ter ações para garantir também aos homens serem ouvidos em suas necessidades;

- Incluir homens na construção de estratégias para resolução do problema (Beiras et al., 2012). 
A necessidade de mais ações direcionadas aos homens, não pode nos impedir de reconhecer a importância da LMP e de constatar que essa lei já alcançou importantes objetivos na sociedade brasileira. De um lado, temos algumas conquistas importantes advindas após a promulgação da lei. De outro temos a impressionante falta de estrutura dos serviços previstos na LMP - alguns desses avanços e desafios são discutidos no próximo tópico. Os impactos da lei já são visíveis, mas precisamos de sua efetivação plena para que tenhamos muito mais conquistas.

\section{Impactos da LMP}

No momento em que a Lei Maria da Penha - LMP foi promulgada no Brasil, 17 países latino-americanos já possuíam legislação específica sobre a violência doméstica e familiar contra as mulheres (Lima \& Büchele, 2011). Apesar de ser uma das legislações mais avançadas do mundo e de ter evitado milhares de mortes, ainda não reduziu significativamente a violência conjugal e os números de feminicídios. Sabemos que os problemas sociais não se resolvem apenas com legislação e a LMP não foi criada para lidar diretamente com o feminicídio. Nenhuma lei será capaz de reverter sozinha o cenário de violência (Ávila et al., 2014; Bandeira, 2009; IPEA, 2013).

A ineficácia no enfrentamento de determinados tipos de violência, de modo especial o feminicídio, se deve especialmente a não aplicação integral da Lei Maria da Penha, seja por falta de estrutura e/ou por recalques patriarcais. A sociedade brasileira ainda é marcada profundamente pela cultura de desigualdade e discriminação de gênero (Ávila et al., 2014; Bandeira, 2009; IPEA, 2013; Yamamoto \& Colares, 2015).

A precariedade da institucionalização das ações previstas na LMP ainda é gritante. Segundo a "Nota Técnica - A institucionalização das políticas públicas de enfrentamento à violência contra as mulheres no Brasil” do IPEA (Martins et al., 2015), até o ano de 2013 o Brasil possuía somente:

- 214 Centros Especializados da Mulher-CEAMs ou CRAMs: em 191 municípios, sendo que esse número equivale a apenas $3,4 \%$ do total de municípios;

- 77 Casas Abrigos em 70 municípios (1,3\% do total de municípios);

- 92 serviços de saúde especializados em 37 municípios (0,7\% do total de municípios);

- 381 Delegacias Especializadas de Atendimento à Mulher - DEAMs em 362 municípios (6,5\% do total de municípios);

- 53 Juizados (em 32 municípios; 0,6\% do total), 45 Varas (em 33 municípios; 0,6\% do total), 40 promotorias (28 municípios; $0,5 \%$ do total) e 46 defensorias (44 municípios; $0,8 \%$ do total). Esses dados deixam claro que as instituições especializadas do sistema de Justiça estavam presentes em menos de $1 \%$ dos municípios brasileiros.

As duas primeiras Casas da Mulher Brasileira foram inauguradas apenas em 2015. A primeira em Campo Grande - MS e a segunda em Brasília - DF. A Casa visa a integração de várias 
áreas do atendimento às mulheres em situação de violência em um mesmo espaço físico por meio do "Programa Mulher: Viver sem Violência" (Brasil/SPM, 2013). O programa preconiza que:

Serviços públicos de segurança, justiça, saúde, assistência social, acolhimento, abrigamento e de orientação para trabalho, emprego e renda passarão a ser integrados por meio do Programa Mulher: Viver sem Violência (...). A iniciativa propõe, aos governos estaduais, estratégias para melhoria e rapidez no atendimento às vítimas da violência de gênero (Brasil/SPM, 2013).

O atual projeto da Secretaria de Políticas para as Mulheres - SPM pretende implantar uma Casa da Mulher em todas as capitais brasileiras (Brasil/SPM, 2013). A quantidade de Organismos de Políticas para Mulheres - OPM é muito precária no Brasil. O relatório da Comissão Parlamentar Mista de Inquérito da Violência contra a Mulher - CPMIVCM confirma a falta de estrutura e as péssimas condições dos poucos serviços existentes. O estudo mostra que o país possui apenas 408 Delegacias da Mulher e 103 núcleos especializados em delegacias comuns. Além da quantidade insuficiente, há uma concentração desses serviços nas capitais e grandes cidades (CPMIVCM, 2013).

Outro importante estudo corrobora essa triste realidade. O Tribunal de Contas da União TCU realizou uma auditoria em 10 estados e no Distrito Federal para avaliar as ações de enfrentamento da violência doméstica e familiar contra a mulher previstas na LMP. O Brasil possui somente $20 \%$ da quantidade mínima de Centros de Referência preconizados pela SPM, e, para piorar o contexto, a maioria dos poucos CEAMs ou CRAMs existente está sem estrutura básica para funcionamento. A auditoria confirmou também o déficit de Casa Abrigos, pois identificou que foram inauguradas apenas 72 das 680 casas previstas pela SPM, quase todas localizadas nas capitais ou regiões metropolitanas (TCU, 2013).

A auditoria do TCU (2013) constatou ainda a precariedade das DEAMs. Em aproximadamente $80 \%$ das delegacias especializadas não há brinquedotecas para as crianças, atendimento noturno e nos finais de semana. Em $72 \%$ delas há escassez de servidores/as. O relatório confirmou a existência de poucos juizados e varas especializados, apenas 94 em todo o país, o que representa menos de $15 \%$ do número previsto. O estado da Paraíba, por exemplo, não possui nenhuma das 29 unidades antevistas. O relatório do TCU corrobora a pesquisa do IPEA (Martins et al., 2015) citada acima. Esses dois levantamentos revelam a extrema carência de juízes/as, promotores/as, oficiais de justiça, servidores/as de apoio e equipes multidisciplinares próprios dos quadros de servidores/as das varas ou promotorias especializadas.

O TCU recomendou à SPM, à Secretaria Nacional de Segurança Pública - SENASP e à Secretaria de Reforma do Judiciário - SRJ a definição de estratégias para ampliação da cobertura da rede de atendimento, sobretudo no interior do país. O TCU ressaltou a importância de criação e intensificação de campanhas direcionadas à população masculina (TCU, 2013). 
A falta de estrutura favorece que a LMP não seja tão efetiva e a população não sinta segurança em buscar os serviços. Segundo uma pesquisa do Instituto Patrícia Galvão/Data Popular (2013), a vergonha e o medo ainda imperam e são os principais motivos relatados pelas mulheres para não se separar do parceiro. De acordo com o referido Instituto, 85\% das pessoas consideram que o risco de homicídio aumenta quando as mulheres denunciam os ex/parceiros. A metade da população tem a percepção de que a forma que a Justiça pune e lida com os homens autores de violência não reduz as agressões.

Pesquisa realizada pelo DataSenado (2013) sobre o impacto da Lei Maria da Penha confirma esses dados: $73 \%$ das mulheres não buscam as vias formais e institucionais de denúncia ou apoio das mulheres. A maioria recorre aos familiares ou aos/às amigos/as. Infelizmente, 15\% das mulheres vítimas não conseguem buscar qualquer tipo de ajuda junto a outras pessoas ou instituições.

Maciel e Barbosa (2010) corroboram esses dados e também afirmam que é muito comum as mulheres ficarem preocupadas de os homens denunciados não seguirem o que a Justiça determina. Diante da precariedade das estruturas e da sociedade machista, muitos homens podem se sentir acima da lei. As pessoas compreendem que "as mulheres ainda estão sozinhas na luta contra a violência e reconhecem os limites das respostas que o sistema de justiça tem dado [à violência e] aos assassinatos de mulheres" (Yamamoto \& Colares, 2015, p. 6).

Apesar dessa falta de estrutura a LMP já conseguiu diversas conquistas no Brasil. Segundo dados da pesquisa do Instituto Patrícia Galvão/Data Popular (2013), 98\% da população ouviu falar da LMP. Para $86 \%$ da amostra, as mulheres estão denunciando mais após a promulgação da lei. A LMP é a lei mais conhecida do país.

A lei contribuiu efetivamente para aumentar as políticas públicas e a percepção da sociedade brasileira sobre a gravidade da violência conjugal e da maior vulnerabilidade das mulheres a esse crime. Houve significativo crescimento das instituições nas esferas federal, estaduais e municipais para o combate dessa forma de violência (Yamamoto \& Colares, 2015).

Um estudo realizado pelo IPEA sobre a efetividade da LMP (Cerqueira, Matos, Martins \& Pinto Júnior, 2015) mostrou que a lei contribuiu para a diminuição em cerca de $10 \%$ da taxa de homicídio contra as mulheres dentro das residências. A Lei Maria da Penha teve importante papel no crescimento dos Organismos de Políticas para Mulheres - OPM. Houve um aumento significativo da quantidade de OPM nos anos seguintes à sua promulgação: 2007, 2008 e 2009. No entanto, depois de 2010 houve uma diminuição no ritmo de implantação (Martins et al., 2015).

A LMP, mesmo com todas as dificuldades e avanços, propõe não ser apenas um instrumento de mudança jurídica, mas também de transformação política, social e cultural. A lei 
sozinha não vai resolver todas as questões, mas a sua efetivação pode contribuir para novos modos de subjetivação, de novas subjetividades masculinas e femininas em nossa sociedade (Maciel \& Barbosa, 2010).

\section{Características dos programas de atenção aos homens no Brasil}

As intervenções junto a homens em dinâmicas de violência conjugal têm muitas características em comum (Oliveira \& Gomes, 2011). Medrado et al. (2011) afirmam que a atenção a homens abrange três categorias ou eixos principais: punição, prevenção e medidas assistenciais.

A punição pode ser vista como uma pena complementar, reeducação ou prisão. A privação de liberdade é tida como um "castigo" para o "agressor", na esperança de que as penas estimulem mudança de comportamento dos autores. A função punitiva é importante em alguns casos, mas não deve ser usada como único recurso. A punição em si não ajuda na prevenção, não serve para inquietar os homens autores a ponto de impedi-los de retomar a violência por medo da punição. $\mathrm{O}$ processo punitivo e vingativo da prisão ainda não se mostrou capaz de fortalecer o potencial de transformação humana. Devemos avançar e alcançar mecanismos alternativos mais eficazes para o enfrentamento da violência (Azevedo, 2008; Medrado, 2009; Medrado \& Méllo, 2008).

As medidas de prevenção compreendem a prevenção primária ou a reeducação para evitar a reincidência. Essas têm como objetivo a "conscientização" dos homens para os prejuízos da violência a todos os envolvidos e para a necessidade do cuidado de si e dos outros e, geralmente, são sugeridos grupos de reflexão para que eles "aprendam" a se relacionar por meio de uma cultura não sexista. Essas medidas partem do pressuposto que os homens foram socializados de forma inadequada e que se faz necessário reeducá-los para evitar a violência. Essa forma de atuação amplia a visão inicial de apenas punir os homens e compreende os homens como sujeitos de necessidades (Medrado et al., 2011).

A reeducação e recuperação dos homens autores devem ser vistas, no entanto, com cuidado e com posicionamento crítico. Tal postura é fundamental, senão corre-se o risco de estigmatizá-los como a parte podre da sociedade. Diante de tal risco, poderia aumentar ainda mais a intolerância e fortalecer os estigmas, tais como a crença errônea de que tirá-los de circulação, formatá-los na prisão e depois devolvê-los ao convívio social seria a solução (Medrado, 2009; Medrado \& Méllo, 2008).

As estratégias de intervenção direta têm os programas de atenção psicológica ou psicossocial como principais recursos (Medrado, 2009; Medrado \& Méllo, 2008). Os objetivos dessas estratégias de acordo com o mapeamento do Instituto NOOS apontou para a concentração das intervenções em sua maioria por meio de grupos reflexivos com o intuito de contribuir para cessar a violência, promover a responsabilização dos homens, buscar formas pacíficas de resolução 
de conflitos e de ressignificação de um estereótipo masculino ou do padrão de masculinidade tradicional hegemônica (Beiras, 2014).

Esses objetivos vão de encontro com os que foram levantados em outros estudos nacionais e internacionais. Os primeiros programas tiveram como objetivos principais a segurança da mulher em conjunto com o reconhecimento e a responsabilização do homem (Lima \& Büchele, Oliveira \& Gomes, 2011; Rothman et al., 2003; Toneli et al., 2010). Medrado \& Méllo (2008) chamam a atenção para o risco de buscar apenas a responsabilização, pois:

incorreríamos na tentação de novamente, responsabilizar o homem, seja individualmente, seja como categoria fictícia (mas que origina práticas), como o responsável pela situação de violência, como fruto de suas características biológicas, "naturais". Assim, basta agir sobre ele, seja por meio de campanhas "preventivas" ou punições (Medrado \& Méllo, 2008, p. 83).

Maciel e Barbosa (2010) compreendem essa necessidade de não focar somente na responsabilização. Consideram o atendimento psicossocial oferecido aos homens no contexto da justiça como um meio de ajudá-los a compreender ações, reações e omissões que contribuíram para sua chegada à Justiça. Essa intervenção é fundamental para eles reconhecerem que toda supremacia e privilégios atribuídos ao masculino também os expõe e os fragiliza. Cabe mencionar, no entanto, que além desses aspectos relacionados à responsabilização, esses pesquisadores afirmam que também é preciso fomentar reflexões que os levem a se perceberem enquanto sujeitos de direito e ampliar sua relação com a Justiça para incluir suas demandas.

\section{Iniciando a caminhada para além da responsabilização}

A busca por objetivos que transcendam a responsabilização no trabalho com os homens não significa banalização da violência. Manita (2008) ressalta a importância de reconhecer as especificidades de estar lidando com pessoas que cometeram crime, mas sem resumi-los a essa condição, principalmente sabendo da diferença da violência conjugal de outros crimes. Atualmente, os programas estão percebendo a necessidade, a possibilidade e os benefícios de ir além da busca da responsabilização. Tal percepção não significa substituir ou descartar a intervenção policial e judicial.

Fávero (2010) acredita e insiste em termos como objetivo a mudança, transformação e reelaboração de significados sobre as masculinidades. Ela confia nos grupos e na reflexão como instrumento para mudança, especialmente nas intervenções que considerem direitos humanos e a prática cidadã. Ela defende que os programas busquem a capacidade de reelaboração dos significados das masculinidades e a críticas às premissas sociais de apoio à violência, para reformulá-las e substituí-las por alternativas saudáveis. 
Boyd-Franklin e Franklin (2003) também entendem os grupos como recursos terapêuticos poderosos para a criação ou ampliação de rede de comunicações e de apoios sociais. Esses pesquisadores consideram a intervenção grupal como uma possibilidade de realizar mudanças e como oportunidade para desafiar mensagens culturalmente conflitivas transmitidas pelas famílias e pelas comunidades. Para eles, os grupos precisam abordar os temas de racismo e de gênero para superar a violência conjugal. Esses pesquisadores ressaltam que cabe acrescentar também a dimensão de classe, de vulnerabilidade social, de precariedade de trabalho, e de acesso a bens e serviços sociais.

Os grupos têm grande potencial de ressocialização para os homens, de permitir novos olhares para as masculinidades entre os pares. Esses grupos podem compor um espaço privilegiado de encontro entre homens, que ainda não é possível nas comunidades, por criar um contexto de aceitação de suas necessidades, de mudança de narrativas e para percepção própria enquanto seres humanos. O acompanhamento psicossocial pode configurar como um encontro de redefinição, construção e ressignificação de subjetividades (Aguiar, 2009; Beiras, 2012; Beiras \& Cantera, 2012).

Esses grupos buscam, inclusive, o comprometimento e o engajamento dos homens nas ações para que a sociedade possa alcançar a equidade de gênero e o fim da violência (Beiras \& Cantera, 2012; Toneli et al., 2010). Para atingir essa potencialidade, temos que conhecer bem as características atuais dos programas brasileiros. Dessa forma, poderemos valorizar as conquistas alcançadas e superar os desafios para uma perspectiva mais favorável de atenção aos homens e rumo a uma sociedade sem violência conjugal.

\section{Contextualização dos programas brasileiros de atenção aos homens}

Diversos estudos foram importantes para realizar uma contextualização dos programas e estudos brasileiros referentes aos homens autores de violência. Cabe ressaltar especialmente o mapeamento dos serviços realizado recentemente pelo Instituto NOOS (Beiras, 2014) e as revisões sistemáticas dos estudos e dos atendimentos com homens autores de violência conjugal de Oliveira e Gomes (2011) e de Lima e Büchele (2011). Baseado nesses estudos, traçamos um breve panorama das abordagens teóricas e epistemológicas, dos métodos, das formas de acesso ou inserção aos programas, das principais dificuldades, aprendizagens e críticas a esses serviços já implantados no Brasil. Em alguns momentos, utilizamos outras referências, nacionais e internacionais para ampliar a visão sobre a realidade desses serviços.

Estudo realizado pelo Instituto NOOS (Beiras, 2014) verificou que a principal abordagem teórica e epistemológica identificada como norteadora dos programas brasileiros é a perspectiva de gênero, adotada em $89,5 \%$ dos serviços. Tal perspectiva é seguida pelos estudos das masculinidades 
e dos direitos humanos com $68,4 \%$ cada. Ficou constatado que 47,2\% adotam o feminismo e a perspectiva psicoeducativa. A perspectiva sistêmica e as múltiplas abordagens ficaram com 26,3\% cada. Por último, alguns trabalhos adotam a abordagem psicanalítica e a comportamental com 10,5 e 5,3\%, respectivamente. Esses dados vão ao encontro com os levantados por Oliveira e Gomes (2011). Eles/as constataram que todos os textos que tratam de estratégias de intervenção consideram a categoria gênero como essencial, seja como abordagem central ou complementar.

Manita (2008) percebeu essa mesma tendência em Portugal. A maioria dos programas de intervenção com homens baseia-se em uma perspectiva de gênero, com leitura feminista ou prófeminista. Outros grandes estudos de revisão sistemática americano (Feder, Wilson \& Austin, 2008) e europeus (Akoensi et al., 2013; Hamilton et al., 2013), bem como alguns estudos nacionais (Lima \& Büchele, 2011; Oliveira \& Gomes, 2011), convergem que ainda não é possível concluir qual tipo ou abordagem de trabalho com homens é melhor e mais efetivo, para qual público alvo e em qual circunstâncias.

Os programas de intervenção com homens no Brasil apresentam grande variabilidade quanto à estratégia ou metodologia de trabalho utilizada. No mapeamento realizado por Beiras (2014), ficou constatado que 68,4\% dos programas associam a intervenção individual e grupal, e que 31,6\% realizam apenas atendimento em grupo. À exceção do SERAV do TJDFT que adota a forma mista, ou seja, que inclui a presença de homens e mulheres no mesmo grupo, as demais iniciativas são trabalhos com grupos exclusivos de homens.

Alguns serviços também fazem grupo de mulheres na mesma instituição. Foi verificado que $68,4 \%$ dessas instituições trabalham com mulheres e outros/as familiares e que $68,4 \%$ possuem número pré-definido de sessões. Quanto à coordenação, o estudo mostrou que 57,9\% dos grupos podem ser coordenados por homens e mulheres, sendo a maioria $(42,1 \%)$ em duplas. Há variações na modalidade de trabalho grupal: 52,6\% são grupos abertos do início ao fim do acompanhamento; 89,5\% dos serviços trabalham em rede e 73,7\% afirmam fazer encaminhamentos (Beiras, 2014).

Oliveira e Gomes (2011) também constataram o predomínio no Brasil de grupos exclusivos de homens. A maioria utiliza os métodos reflexivos ou educativos. Apenas uma minoria considerou o trabalho grupal como terapêutico. O estudo verificou que existem algumas variações interessantes, tais como atendimentos individuais, associados com grupos de mulheres; grupo de mulheres autoras; mediação familiar precedida por grupo de homens; atendimento de casal e família, com atendimentos em conjunto e separados.

Modalidades de atendimento a outras pessoas do grupo familiar também foram identificadas. Nesse contexto, prevaleceu as intervenções com as ex/parceiras e familiares dos homens autores de violência. Alguns serviços realizam as intervenções com essas pessoas em 
espaços separados dos homens, tais como no Centro Especial de Orientação à Mulher - CEOM de São Gonçalo/RJ. Outros serviços, tais como o SERAV do TJDFT ou o NAFAVD do GDF, realizam atividades distintas no mesmo espaço físico e em dias diferentes (Aguiar, 2009; Chaves \& Silva, 2010; Figueira, 2011; Ghesti-Galvão et al., 2010; Lima \& Büchele, 2011; Macedo, 2013; Moreira \& Matta, 2006; Rangel \& Tusi, 2010).

Essas experiências se diferenciam da maioria dos serviços latino-americanos por atenderem homens e mulheres no mesmo local. Os serviços que integram os atendimentos percebem várias vantagens, dentre elas ter mais subsídios para avaliar a mudança ou não dos comportamentos violentos dos homens e conseguir melhores intervenções relacionais, inclusive quanto aos aspectos de gênero. Além desses benefícios, não foi identificado risco ou reflexo negativo para o trabalho com as mulheres (Lima \& Büchele, 2011; Macedo, 2013; Moreira \& Matta, 2006).

As formas de acesso ou inserção dos homens junto aos serviços também foram investigadas no estudo de Beiras (2014). Prevalecem a forma exclusivamente espontânea e a exclusivamente obrigatória, com 36,8\% dos casos para cada. Em 26,3\% dos serviços pode ser pelas duas formas. Oliveira e Gomes (2011) encontraram resultados diferentes em seu estudo. O meio majoritário de acesso foi o compulsório, ou seja, os/as participantes foram geralmente encaminhados pela justiça, delegacias, abrigos, conselhos.

As principais dificuldades apontadas pelos/as profissionais desses serviços se devem à falta de continuidade dos programas, dependência de mudança de gestão pública, questões específicas dos serviços, dificuldades de encaminhamento para a rede e de aprimoramento do serviço. Vale ressaltar, que não figurou como dificuldades principais o manejo com os homens. Ao contrário, a possibilidade de transformação e o reconhecimento da importância de se trabalhar com os homens foram apontadas como algumas das principais vantagens e aprendizados dessa prática (Beiras, 2014).

Alguns estudos, no entanto, apontam resultados modestos, em função da dificuldade de vinculação dos homens, da necessidade de estreitar parcerias com a justiça, polícia e saúde e da ausência de avaliações formais. Esses estudos evidenciaram também os altos índices de desistência, que variam entre 20 e $50 \%$, tanto em homens que acessam os serviços de forma voluntária ou por medida judicial. Esses obstáculos enfrentados convergem com algumas pesquisas internacionais e precisam ser constantemente avaliados (Lima \& Büchele, 2011).

Matjasko et al. (2012) encontraram oito estudos de meta-análise e de revisão sistemática sobre programas de intervenção com homens jovens nos EUA. Seis deles encontraram resultados com efeitos consideráveis dessas intervenções, em que a não reincidência variou entre 36 a $70 \%$. A maioria dos programas tinha como base a terapia cognitiva comportamental, terapia sistêmica e/ou 
treino de habilidades sociais. Duas iniciativas tiveram baixos efeitos, mas primaram em estudos com foco nas intervenções exclusivas com os jovens, sem abordar as famílias e redes sociais. Esse estudo confirma a importância de uma intervenção mais ampla e complexa com os homens autores de violência, assim como aponta para a relevância da atenção às estratégias de avaliação dos tipos de intervenção.

Algumas pesquisas interessantes foram realizadas para contornar essas dificuldades. Scott et al. (2011) realizaram um estudo no Canadá sobre os efeitos de um grupo motivacional para favorecer a adesão de homens autores de violência extremamente resistentes a intervenções. Os participantes foram divididos em 3 amostras. A primeira e a segunda amostras foram compostas por homens não resistentes e resistentes, respectivamente, que passaram apenas pela intervenção tradicional de 16 encontros. A terceira amostra foi de homens resistentes que passaram pela intervenção motivacional de seis encontros e depois mais 10 encontros do grupo tradicional. O grupo motivacional aumentou consideravelmente o índice de adesão $(84,2 \%)$ de homens resistentes quando comparado a outros homens que passaram somente pela intervenção tradicional, com taxas de adesão de 46,5\% para os homens resistentes e de 61,1\% para os homens não resistentes.

As características das intervenções no Brasil são marcadas pela diversidade, criatividade e riqueza metodológica. Essa amplitude de tipos de intervenções também abre margem para críticas. Oliveira e Gomes (2011) constataram a presença de dois tipos de estudos que criticam os programas atuais de intervenção com homens no Brasil.

O primeiro grupo de críticas às intervenções efetuadas aponta para a necessidade de ter propostas mais ancoradas na perspectiva feminista. Guareschi et al. (2004) são contra o anonimato dos grupos "agressores anônimos", por ter o risco de despolitizar e privatizar o tema. Marques (2007) denuncia as intervenções muito psicologizadas ou individualizantes, por não reconhecerem os aspectos relacionais e culturais e desenvolverem um discurso vitimário dos homens. Toneli et al. (2008), Grossi (2001); Lima e Mello (2008) são contra abordagens puramente técnicas, tais como o controle da raiva, que geralmente são seguidas de formas mais sutis da violência, pois os homens não modificam os valores que sustentam a violência (Oliveira \& Gomes, 2011).

Toneli et al. (2008) argumentam que "muitos homens que passam por estes programas aprendem a controlar sua violência, mas não deixam de se identificar e conduzir segundo valores tradicionais de masculinidade, que implicam formas mais sutis de opressão" (p. 7). Por último, Grossi (1998) e Nolasco (2001) fazem oposição ao feminismo clássico e buscam contribuições alheias ao feminismo. Grossi enfatiza a necessidade de políticas de discussão sobre o "amor romântico" e Nolasco defende o fortalecimento cultural das masculinidades (Oliveira \& Gomes, 2011). 
O segundo grupo de críticas levantado no estudo de Oliveira \& Gomes (2011) defende mais atenção aos homens. Méllo e Medrado (2008) são contra a lógica naturalizante do homem como agressor e a universalização das conjugalidades violentas. Lima e Méllo (2008) criticam os profissionais que naturalizam o homem como "agressor". Granja (2008), Méllo e Medrado (2008), Lima e Méllo (2008) são contra as intervenções que não vão além da responsabilização. Oliveira (2006) traz várias falas de homens que se sentiram extremamente invadidos, recriminados ou excluídos em atendimentos psicossociais. Muszkat (2003) reforça essas críticas ao constatar que a inclusão de homens nos atendimentos aumentou significativamente a eficácia das intervenções com as mulheres.

Diante das dificuldades apontadas e dos dois conjuntos de críticas, alguns estudos defendem e outros são contra o encaminhamento compulsório aos serviços. Os que são a favor argumentam que o mero acompanhamento facultativo de homens autores não demonstra bons resultados de engajamento (Ávila et al., 2014). Para Aguiar (2009), os próprios participantes reconheceram a importância do encaminhamento compulsório e da transformação da demanda nos atendimentos psicossociais.

Os estudos que são contra afirmam que o encaminhamento compulsório pode ser uma violência, já que a motivação é baixa e que os homens apenas comparecem para evitar a punição ou prisão (Guareschi et al., 2004; Manita, 2008). Para Manita, a busca espontânea tem vantagem no prognóstico, pois presume-se que a pessoa já tenha alguma consciência da existência de problema, dos danos em terceiros ou em si e a vontade para alterar o seu comportamento.

Uma forma comum de busca por ajuda acontece quando a mulher ameaça separar do parceiro. A busca de ajuda é uma forma de evitar a separação. Em todos esses casos, os profissionais devem tomar muito cuidado na avaliação dos pedidos dos homens, pois esse pedido de ajuda pode ser uma estratégia de reconquista da vítima e o recomeço do ciclo da violência.

Consideramos que as duas formas de acesso ou inserção nos serviços têm vantagens e desvantagens. A depender do contexto e dos objetivos da instituição, o encaminhamento compulsório ou voluntário é mais adequado. O importante é garantir treinamento adequado dos/as profissionais para o manejo dos desafios presentes em cada forma de inserção dos homens, inclusive para realizar a transformação da demanda quando o comparecimento for obrigatório. É importante que os/as profissionais estejam conscientes e preparados/as para lidar com as dificuldades e aproveitar as vantagens de cada uma das formas de encaminhamento.

As intervenções com homens em dinâmica de violência conjugal avançaram muito no Brasil. A contextualização dos serviços revelam verdadeiras riquezas metodológicas, criatividade e diversidade nas atuações com homens, mulheres e familiares. Temos que valorizar as inúmeras 
conquistas, mas ao mesmo tempo continuarmos atentos/as aos vários desafios que ainda estão presentes e aos outros que surgirão nesse contexto de trabalho. Temos muito a caminhar para superá-los. Precisamos de novas perspectivas para realmente dar uma atenção digna e humana aos homens como um dos meios imprescindíveis rumo a uma sociedade livre da violência conjugal e com maior equidade de gênero nas relações sociais e familiares.

\section{Perspectivas futuras: aproximar para compreender masculinidades}

Ponce-Antezana (2012) fez um panorama dos modelos predominantes de intervenção com homens em diversos países a partir de sua experiência enquanto psicoterapeuta e pesquisador na área. De forma bem resumida, os três modelos principais foram/são: 1) modelo psicopatológico tinha como foco os distúrbios da personalidade - os homens eram vistos como doentes; 2) enfoque psicoeducativo pró-feminista: que considera as questões sociais, mas procura modificar aspectos negativos do comportamento dos homens; 3) enfoque cognitivo-comportamental: que entende a violência como um problema dos pensamentos, crenças e condutas do indivíduo.

Ponce-Antezana (2012) afirma que esses modelos diminuem consideravelmente as possibilidades de mudança dos homens. Muitos profissionais tendem a não demonstrar interesse em ouvir a narrativa da vivência dos homens em primeira pessoa, pois consideram importante avaliar o risco, coletar e objetivar os discursos em terceira pessoa. Lamentavelmente, nesse contexto, eles tratam a violência como se fosse apenas uma questão de informação ou conhecimento.

Muitos profissionais, infelizmente, assumem uma perspectiva objetivista e uma posição de alguém que tem acesso direto à realidade e o próprio homem não. Esse lugar de poder dos profissionais pode reproduzir as mesmas práticas de violência que eles pretendem combater e submeter à revisão. Paradoxalmente, a adoção de tal postura pode manifestar a mesma cultura de violência que se objetiva enfrentar (Azevedo, 2008; Ponce-Antezana, 2012).

O objetivo da intervenção nessas perspectivas resume-se ao controle, eliminação ou evitação das experiências vividas, gerando situações paradoxais. Muitos homens não vão conseguir deixar de sentir vontade de agredir, mesmo sabendo que "não é correto". Dessa forma, os homens podem ter como única ferramenta o autocontrole ou a repressão de sentimentos, que em muitas situações não são suficientes para evitar a re/instalação da violência (Manita, 2008; Ponce-Antezana, 2012).

Beiras (2009) e Beiras et al., (2012) corroboram essa visão. Esses autores criticam as intervenções convencionais que buscam identificar apenas as causas lineares da violência conjugal, o perfil do "agressor" ou explicações intrapsíquicas. Elas não são satisfatórias ou suficientes.

Muitos grupos que trabalham com intervenção, apesar de bem intencionados, possuem visões criminalizantes e patologizantes do "agressor". A maioria dos grupos na Europa, por exemplo, são realizados por psicólogos clínicos com perspectiva cognitiva comportamental e têm 
como objetivo a mudança de conduta. De acordo com a pesquisa de Beiras et al. (2012) esses grupos possuem viés patologizante e classificatório, com uma leitura de gênero restrita apenas aos estereótipos sociais.

Medrado e Méllo (2008) e Medrado (2009) afirmam ser necessário não enxergar os homens como delinquentes, deficientes ou desajustados. Defendem a instauração da dúvida sobre as "certezas" da ciência sobre o indivíduo, sobre a dinâmica de violência e sobre as medidas jurídicas generalizantes. Afirmam que não faz parte do papel dos cientistas sociais serem reveladores da verdade dos fatos. Assim, esses pesquisadores trazem a esperança de que as intervenções psicossociais "não se tornem mais uma ferramenta de criminalização da situação de violência, ou castigo para os homens (quase uma 'pena alternativa'), mas que permitam uma ampliação do diálogo coibido tanto pela situação de violência quanto pela aplicação da Lei” (Medrado, 2009, p. $85)$.

Essa visão pode gerar políticas e práticas distorcidas. As ideologias, estereótipos, dicotomias, criminalização e vitimização estão presentes em textos, leis e nas políticas públicas e podem contribuir para o aumento e não para a diminuição ou contenção de atos violentos nas relações afetivas. Dessa forma, o sistema jurídico também pode ao mesmo tempo configurar como solução e como "solução-problema". A junção entre sanção e processo terapêutico pode ser efetiva em vários casos, mas para que esse contexto seja adequado, precisa ir além de mudanças cognitivocomportamentais, para buscar reflexões, questionamentos e a promoção de processos de crescimento pessoais em termos mais ecológicos, sistêmicos e construcionistas (Beiras et al., 2012)

Urge a ampliação desses modelos. Faz-se necessária a superação de uma visão positivista, cientificista e individualista e a inclusão de perspectivas de gênero com uma compreensão complexa, interdisciplinar, interseccional, interpretativa, social, histórica, não-positivista e nãocolonizadora (Ponce-Antezana, 2012).

Ponce-Antezana (2012) defende, assim, um enfoque construtivista-narrativista com perspectiva de gênero. Esse modelo entrelaça as perspectivas socioconstrucionistas e construtivistas, entende os seres humanos como coconstrutores proativos da realidade pessoal e social. Abrange o contexto sociocultural e político dos enfoques pró-feministas e das teorias de gênero, mas considera continuamente a dialética entre o social e o individual.

Ravazzola (2007) corrobora essa visão ao perceber as vantagens das contribuições do construcionismo social, das teorias da complexidade, das propostas colaborativas, dos estudos das emoções, dos estudos das diversidades. Ela defende a somatória da visão sistêmica aos estudos de gênero, que tem grande potencial para serem utilizados com os homens, mulheres e as famílias afetadas pela violência. Outros/as autores/as corroboram essa conexão ao adotarem uma abordagem 
clínica que integram uma perspectiva sistêmica feminista (Angelim, 2004; Diniz, 2011; Pondaag, 2003).

Lima e Büchele (2011) defendem a diversidade de modelos teóricos e de diferentes lentes como meio de superar a violência. $\mathrm{O}$ trabalho interdisciplinar ganha destaque para a construção de uma "cidadania de gênero" e para o amadurecimento social, baseados na equidade e no respeito às diferenças. Assim, os grupos reflexivos podem ser contextos que favorecem a "ressocialização destes sujeitos, atentos à ressignificacão de mandatos tradicionais de masculinidades e feminilidades em consonância ao movimento feminista, de maneira a responsabilizar o autor de violência e promover empoderamento e mudanças subjetivas em homens e mulheres" (Beiras et al., 2012, p. 40).

A aposta na interdisciplinaridade da intervenção com homens é quase um consenso na literatura da área. Medrado et al. (2011) apontam a insuficiência de disciplinas isoladas para a completa apreensão e transformação da violência. Ponce-Antezana (2012) complementa essa ideia ao afirmar que a interdisciplinaridade não é simples troca de informações entre disciplinas. $\mathrm{O}$ autor vai além ao definir a necessidade de compreensão transdisciplinar, que traz a contribuição de maior quantidade de ângulos e perspectivas. Dessa forma, as transformações podem ser profundas, envolventes e significativas.

A dimensão do gênero é reinterpretada nessa perspectiva. Inclui em sua análise diferentes tipos de empoderamento, opressão e discriminação, inclusive os aspectos de classe social, raça, nacionalidade etc. O objetivo desse enfoque é desenvolver um marco de respeito e colaboração que permita o estabelecimento de diálogo com os homens a respeito de suas próprias experiências, vivências, sentimentos, significados e intenções. Dessa forma, busca "desafiar as conformidades sociocontextuais próprias dos privilégios masculinos, procurando substituir os círculos viciosos superconformistas por círculos virtuosos e criativos" (Ponce-Antezana, 2012, p. 16).

As ações com homens autores de violência conjugal contra mulheres podem favorecer processos de empoderamentos humanos como proposta de compreensão e intervenção da violência. Podem abranger uma tentativa de criar e fortalecer pontes e acreditar na capacidade de transformação do indivíduo (Ponce-Antezana, 2012). Dessa forma, muito mais que um espaço de tratamento, espera-se que sejam criados espaços de escuta para homens em situação de violência conjugal (Medrado, 2009; Medrado \& Méllo, 2008). Esses pesquisadores apostam na construção de condições favoráveis de circulação da diversidade para facilitar a reflexão dos homens para que eles possam refazer escolhas e se contrapor à violência.

Nesse sentido, a Lei Maria da Penha pode contribuir para que homens recebam na Justiça e em outros espaços muito mais que tratamento ou punição. A lei tem possibilidade de construção de 
sentidos e de potencial transformador em suas diferentes formas de ampliação de medidas que vão além da prisão. Assim, as desigualdades e assimetrias de poder podem ser melhor negociadas, modificadas e transformadas. Podem ser criados verdadeiros contextos de escuta crítica, ética e realmente transformadora (Medrado, 2009).

Ponce-Antezana (2012) afirma que é possível e preciso realizar verdadeiras reformulações no conceito da violência, na forma de compreender o ser humano e suas possibilidades de mudança assim como o lugar do/a facilitador/a. Essa mudança de perspectiva pode ajudar a melhorar as intervenções e descobrir a sua tarefa transformadora por meio de formas mais compreensivas e empáticas, que não foquem somente no déficit ou defeito, mas que considerem as fortalezas, capacidades e habilidades positivas; que validem e reconheçam as experiências e vivências pessoais. $\mathrm{O}$ autor aponta a necessidade de que o sistema e os profissionais que nele atuam consigam enxergá-los como pessoas capazes e com potencial em outros âmbitos. O enfrentamento da violência pode e deve ser travado contra as posições e contextos de poder e não contra as pessoas, não contra os homens.

Essa perspectiva convida os/as profissionais a se aproximarem mais e a conhecerem o próprio ponto de vista dos homens em vivência de violência conjugal. Por isso, requer a coconstrução de formas mais empáticas, que sejam mais flexíveis e ajustadas para motivar. Essa perspectiva respeitosa, colaborativa e compreensiva tem o desafio de fazer uma rejeição clara à violência, mas ao mesmo tempo, aceitar o indivíduo. Tem como premissa que compreender não significa justificar. Por meio de uma relação de confiança, os homens podem refletir de forma crítica sobre sua própria práxis masculina, mas sem sentirem julgados e ameaçados. São convidados a transformar tais práticas violentas de uma forma mais humana, não por meio de mais violência (Ponce-Antezana (2012).

Essa aproximação dos homens autores pode favorecer uma melhor compreensão da violência conjugal e subsidiar novas propostas de políticas, ações e intervenções com essa população para buscar efetivamente a revisão dos processos de negação, minimização e a desresponsabilização da violência. Assim, poderemos ter mais recursos para desconstruir a naturalização da violência conjugal e ampliar os meios para o efetivo enfrentamento desse fenômeno e a construção da equidade de gênero em nossa sociedade. 


\title{
Capítulo 4
}

\author{
Método \\ Como pôde \\ Queimar nosso filme \\ Um longe do outro \\ Morrendo de tédio e de ciúmes \\ O que que há com nós dois amor? \\ Me responda depois \\ Me diz por onde você me prende \\ Por onde foge \\ E o que pretende de mim \\ (Música: Acontecimentos - Marina Lima)
}

A violência conjugal constitui um tema importante de pesquisa. Randle e Graham (2011) afirmam que existem muitas lacunas nos estudos sobre violência e masculinidades, especialmente a necessidade de mais pesquisas qualitativas. Esses pesquisadores defendem que os estudos precisam contemplar as experiências e vivências de homens no contexto de violência conjugal.

A pesquisa qualitativa é importante na Psicologia Clínica. O principal objetivo desse tipo de pesquisa é caracterizar, compreender e interpretar o fenômeno (Seidl de Moura \& Ferreira, 2005). Nosso desafio foi encontrar uma forma de ajudar os homens autores de violência a manifestarem mecanismos de negação, minimização e desresponsabilização da violência vivida. Esse pode ser um primeiro passo na construção de um processo de identificação, reflexão, revisão de anestesias e de aspectos de duplo-vínculos presentes em sua relação conjugal e constitui uma etapa fundamental do trabalho com homens nessa situação. Consideramos, assim, que esse tema de pesquisa pode ter relevância teórica e clínica.

Reconhecemos ser importante estudar e identificar anestesias e critérios de duplo-vínculos tanto na perspectiva de homens quanto de mulheres. Privilegiamos começar pelas mulheres na pesquisa de mestrado (Guimarães, 2009), pois são elas que geralmente estão em maior situação de risco e sofrem os maiores impactos da violência conjugal (Macedo, 2013; Medeiros, 2010; Soares, 2005). É extremamente relevante e fundamental também incluir os homens como participantes de pesquisas sobre o tema (Aguiar, 2009; Aguiar \& Diniz, 2008; Medrado, 2010; Medrado, Lemos \& Brasilino, 2011). Essa tese de doutorado tem o objetivo de ser mais um passo nesse sentido.

Homens autores de violência conjugal tendem a apresentar concepções estereotipadas de gênero que podem ser prejudiciais a todos/as envolvidos/as na relação conjugal (Alvarenga, 2012; Juras, 2009; Oliveira, 2015; Silva, 2012, Siqueira, 2012). Essas características tendem a ser extremamente deletérias aos próprios homens (Araújo, 2012; Macedo, 2013; Randle \& Graham, 2011). Uma tendência à adesão rígida a papéis estereotipados de gênero contribui para a 
naturalização dos atos e da dinâmica marcada pela violência. Essa naturalização da violência favorece a instalação e manutenção de anestesias relacionais e de critérios duplo-vinculares na dinâmica conjugal, que dificultam a percepção pelos homens e pelas mulheres das consequências da violência e favorecem o aprisionamento de ambos na relação.

Trabalhar com homens em situação de violência conjugal constitui um desafio importante e requer novas estratégias metodológicas. Tivemos que ampliar os recursos para estudar os fatores que colaboram para que os homens autores de violência também se sintam aprisionados e permaneçam sem condições de refletir em uma relação estruturada pela violência. Nós buscamos identificar anestesias relacionais apresentadas pelos homens autores de violência que mais influenciam a manutenção da dinâmica conjugal com violência. Tentamos conhecer como os próprios homens nomeiam e percebem a sua história, utilizando o título do livro como elemento estimulador para identificação de características duplo-vinculares da relação que estruturam as dinâmicas conjugais permeadas pela violência.

Adotamos como parte da estratégia de pesquisa o uso de um estímulo indutor de reflexões, no caso o livro "Mas ele diz que me ama" (Penfold, 2005/2006). O livro foi escrito por uma mulher vítima, que reflete sobre a dinâmica conjugal e aponta suas ações e reações - bem como as de seu parceiro - diante da instalação, manutenção e escalada da violência na relação. Buscamos na história desse casal, escrita de forma criativa, o estímulo para reflexões sobre a experiência de violência conjugal de homens.

Tivemos o intuito de verificar se homens autores manifestam a tendência de naturalizar a violência ao compararem a história do livro com as próprias vivências. Pretendemos analisar se homens conseguem perceber o sofrimento dos personagens do livro e se essa identificação favorece a reflexão sobre o próprio padrão conjugal.

A partir de abordagem sistêmica feminista e de gênero, essa pesquisa de doutorado teve como objetivo geral identificar como homens autores de violência conjugal que participaram de pesquisa como parte de uma intervenção psicossocial na Justiça manifestam indícios de anestesias relacionais e de dimensões duplo-vinculares da dinâmica, por meio da leitura e reflexão em grupo do livro: "Mas ele diz que me ama" (Penfold, 2005/2006).

A revisão de literatura revelou a tendência de homens autores a naturalizarem a violência em suas relações e a perceberem as agressões de outros homens como sendo mais graves que aquelas cometidas por eles próprios no contexto de sua relação (Aguiar, 2009; Chaves \& Silva, 2010; Dohmen, 2006; Figueira, 2011; Ghesti-Galvão, Machado \& Costa, 2010; Moreira \& Matta, 2006; Oliveira \& Gomes, 2011; Rangel \& Tusi, 2010). Pesquisas também mostraram que homens autores de violência conjugal tendem a escutar com mais facilidade outras mulheres vítimas do que a suas 
próprias parceiras ou ex-parceiras (Chaves \& Silva, 2010; Ghesti-Galvão, Machado \& Costa, 2010; Moreira \& Matta, 2006; Papp, 2002; Ramos, 2013; Santos, 2015).

Os resultados dessas pesquisas foram o ponto de partida para a problematização e o delineamento da questão de pesquisa que serve de base para essa tese (Seidl de Moura \& Ferreira, 2005): Como homens autores de violência conjugal encaminhados para intervenção grupal junto ao sistema de Justiça expressam a negação, a minimização e a desresponsabilização da violência em suas vivências quando em contato com a história dos personagens do livro "Mas ele diz que me ama" (Penfold, 2005/2006)?

Essa questão de pesquisa implica em oito perguntas adicionais, que formam a base para o delineamento dessa tese (Seidl de Moura \& Ferreira, 2005). As principais perguntas que pretendemos responder ao longo desse trabalho são:

1. O acesso pelos homens aos sentimentos, pensamentos e ações descritos pelos personagens do livro favorece o contato e a manifestação de seus próprios sentimentos?

2. Ter contato com os próprios sentimentos permite refletir sobre a sua relação conjugal?

3. Alguns participantes conseguirão identificar aspectos parecidos e/ou diferentes da história do livro com suas próprias vivências?

4. Essa comparação favorece a reflexão sobre a própria relação?

5. Essa comparação beneficia o início do processo de nomeação da violência na sua relação conjugal?

6. Essa comparação entre as histórias contribui para a identificação da naturalização da violência por parte dos homens autores?

7. Os participantes conseguirão manifestar e/ou identificar os próprios sentimentos e pensamentos que indicam anestesias relacionais a partir do estímulo das anestesias descritas pelos personagens do livro?

8. O início do processo de nomeação da própria história a partir do título do livro contribui para a identificação de algumas dimensões duplo-vinculares em suas relações?

Esperamos que a estratégia metodológica utilizada consiga responder as questões acima e tenha se configurado como um relevante espaço de escuta e uma valiosa oportunidade para esses homens perceberem e resignificarem a violência conjugal cometida contra suas parceiras ou exparceiras. A dimensão inovadora dessa estratégia justifica o caráter exploratório da pesquisa (Seidl de Moura \& Ferreira, 2005). Essa pesquisa é pioneira, pois não encontramos estudos sobre masculinidades, anestesias relacionais e dimensões de duplo-vínculos em relacionamentos marcados pela violência conjugal, especialmente na perspectiva de homens autores de violência. 


\section{Contexto da pesquisa}

Essa pesquisa foi realizada no contexto de acompanhamento psicossocial de duas importantes instituições governamentais que atendem homens autores de violência conjugal no Distrito Federal: SERAV/TJDFT e NAFAVD/SEMIDF/GDF. O Serviço de Assessoramento aos Juízos Criminais - SERAV é um serviço do Tribunal de Justiça do Distrito Federal e dos Territórios - TJDFT e atende homens em situação de violência doméstica desde o ano de 2000 (Ghesti-Galvão \& Roque, 2010; Lobão, Resende \& Roque, 2012; Roque, Moura \& Ghesti, 2006). O Núcleo de Atendimento às Famílias e Autores de Violência Doméstica - NAFAVD pertence à Secretaria de Política para Mulheres, Igualdade Racial e Direitos Humanos - SEMIDF do Governo do Distrito Federal - GDF e faz intervenção com homens desde 2003 (Aguiar, 2009; Aguiar \& Diniz, 2008; Beiras, 2014; Figueira, 2011).

A escolha pelo SERAV e pelo NAFAVD se deve ao fato de se diferenciarem da maioria dos serviços latino-americanos por serem inseridos como política pública do Estado, por priorizarem a intervenção com homens e mulheres desde o início de suas atuações na área de violência e por atenderem os cônjuges no mesmo local. Esses serviços realizam atividades distintas no mesmo espaço físico e em dias diferentes, bem como intervenção conjugal quando necessário (Aguiar, 2009; Chaves \& Silva, 2010; Figueira, 2011; Ghesti-Galvão et al., 2010; Lima \& Büchele, 2011; Macedo, 2013; Moreira \& Matta, 2006; Rangel \& Tusi, 2010).

Lima e Büchele (2011) afirmam que o atendimento aos homens ainda não se configura como política pública, mas há uma tendência cada vez mais emergente de caminhar nessa direção. Nós concordamos com as autoras e também defendemos a implantação e priorização de mais serviços sob a responsabilidade do Estado no enfrentamento da violência.

Outros estudos (Lima \& Büchele, 2011; Macedo, 2013; Moreira \& Matta, 2006) corroboram que os serviços que integram os atendimentos a homens e mulheres percebem várias vantagens, dentre elas ter mais subsídios para avaliar a mudança ou não dos comportamentos violentos dos homens e conseguir melhores intervenções sistêmicas, inclusive quanto aos aspectos de gênero. Além desses benefícios, essas pesquisas não identificaram riscos ou reflexos negativos para o trabalho com as mulheres.

O objetivo de trabalhar com homens em acompanhamento psicossocial em duas instituições e em momentos distintos do processo grupal pode ampliar a possibilidade da análise das semelhanças e diferenças nas percepções e reflexões de homens de cada grupo. O método de intervenção distinto do SERAV e do NAFAVD contribuirá no sentido de trazer uma visão mais ampla de dimensões do fenômeno estudado. Dessa forma, pode-se aproveitar as vantagens e potencialidades de cada modalidade de intervenção grupal com homens em situação de violência, 
seja em grupo misto no SERAV ou em grupo composto exclusivamente por homens no NAFAVD. Descreveremos brevemente o contexto de atuação dessas duas instituições estatais pioneiras no Brasil no atendimento a homens autores de violência conjugal.

\section{Serviço de Assessoramento aos Juízos Criminais - SERAV}

O SERAV enquanto equipe psicossocial, composta por servidores da área de Serviço Social e Psicologia, constitui-se como ator estratégico na Justiça do Distrito Federal para a execução de trabalhos pioneiros na área de violência doméstica e familiar no âmbito da Justiça. O SERAV é ligado a Subsecretaria Especializada em Violência e Família - SUAF da Secretaria Psicossocial Judiciária - SEPSI do Tribunal de Justiça do Distrito Federal e dos Territórios (Ghesti-Galvão \& Roque, 2010; Lobão, Resende \& Roque, 2012; Roque, Moura \& Ghesti, 2006).

O acompanhamento psicossocial do SERAV é amplo e abrange casos de violência doméstica e familiar contra mulher no contexto da Justiça. A intervenção é baseada nos artigos 29 e 30 da Lei Maria da Penha (Brasil, 2006). As três linhas de atuação principais do SERAV são em casos de violência conjugal, de maus-tratos e de abuso sexual. O estudo e a intervenção psicossocial são realizados de diversas maneiras, de acordo com os referenciais teóricos da Psicologia e do Serviço Social, incluindo intervenções individuais, familiares, grupais, bem como realização de visitas domiciliares/institucionais e elaboração de parecer psicossocial aos/às magistrados/as. A intervenção prioriza a compreensão interdisciplinar, complexa, social e sistêmica do fenômeno da violência (Ghesti-Galvão \& Roque, 2010; Lobão, Resende, Roque \& Brito, 2012).

O objetivo geral do SERAV é assessorar os/as magistrados/as para ampliação da compreensão da dinâmica familiar e conjugal marcada pela violência. Os quatro principais focos das intervenções são:

1) Embasar as decisões judiciais por meio da prática da interdisciplinaridade para enriquecer a compreensão dos/as magistrados/as acerca da violência;

2) Avaliar o nível de vulnerabilidade psicossocial das pessoas envolvidas na violência e os fatores de risco e de proteção envolvidos na relação;

3) Proporcionar e facilitar reflexão dos/as jurisdicionados/as para que eles/as possam ampliar a compreensão da relação entre os seus aspectos sócio-familiares/pessoais e o fato delituoso, bem como buscar recursos que lhes permitam lidar ou superar as suas dificuldades relacionais. Essa intervenção é focal e breve com as partes;

4) Sensibilizar e encaminhar as pessoas para a Rede Social parceira do SERAV, baseado nos fatores de risco e de gravidade do caso (Macedo et al., 2012; SEPSI/TJDFT, 2009; SERAV, 2012). 
O SERAV atua no Plano Piloto e em mais quatro Regiões Administrativas do Distrito Federal: Ceilândia, Núcleo Bandeirantes, São Sebastião e Planaltina. Os postos descentralizados do SERAV funcionam nos fóruns e recebem a demanda de juizados e varas criminais dessas regiões administrativas próximas. O posto do Plano Piloto recebe os casos das demais cidades que ainda não possuem o serviço descentralizado (Macedo et al., 2012; SEPSI/TJDFT, 2009; SERAV, 2012).

Nos casos específicos de violência conjugal, as pessoas envolvidas são encaminhadas judicialmente para esse serviço em audiências interdisciplinares ou por juízes após formalização de queixa de violência conjugal. As audiências interdisciplinares contam com a participação da equipe psicossocial do SERAV (Macedo et al., 2012). O estudo psicossocial geralmente acontece em grupos: "Grupo de Avaliação de Medidas Protetivas" e "Grupo de Avaliação da Dinâmica Conjugal” (Beiras, 2014). O primeiro geralmente é intitulado como "Grupo de Avaliação" e o segundo é mais conhecido no SERAV como "Grupo Misto - GM" (Ghesti-Galvão, Machado \& Costa, 2010; Moreira \& Matta, 2006; Santos, 2015).

O Grupo de Avaliação acontece com um atendimento em grupo para cada pessoa do casal com o intuito de avaliar a necessidade (ou não) de Medidas Protetivas de Urgência - MPU, bem como o des/cumprimento das mesmas. O Grupo Misto tem de três a cinco encontros com frequência semanal de duração de até duas horas. Esse grupo é aberto para a entrada de novos participantes a qualquer momento, bem como para a saída das pessoas que finalizam o acompanhamento psicossocial. Todo encontro pode ter participantes iniciando ou encerrando o processo grupal (Moreira \& Matta, 2006; Santos, 2015).

Esses grupos fazem parte de um conjunto de procedimentos de atendimento do SERAV. Quando há necessidade, podem-se realizar outras formas de intervenções, especialmente atendimentos conjugal, familiar e visitas institucionais ou encaminhamentos para a Rede Social parceira do SERAV. Vale ressaltar, que não faz parte do objetivo desses grupos contemplar todas as intervenções necessárias aos homens e mulheres envolvidos em violência conjugal, o intuito é fazer uma intervenção breve e focal para assessoramento dos/as magistrados por meio de avaliação de cada caso e sensibilização para encaminhamentos para a rede social (Chaves \& Silva, 2010; GhestiGalvão, Machado \& Costa, 2010; Moreira \& Matta, 2006; Rangel \& Tusi, 2010).

Escolhemos aplicar a pesquisa no contexto do Grupo Misto por ele ter mais encontros. Essa escolha viabilizou a estratégia metodológica adotada, pois foram necessários dois encontros para os procedimentos na primeira etapa da pesquisa, conforme descrevemos no tópico sobre as estratégias de coleta de dados. Apresentamos abaixo as principais características desse grupo.

Cada encontro do Grupo Misto é planejado pela dupla de técnicos/as e pode ser organizado com temas específicos, tais como violência, gênero, comunicação, autocuidado, redes sociais etc. 
(Guesti-Galvão, Machado \& Costa, 2010) ou com temas levantados pelos/as participantes do próprio grupo (Chaves \& Silva, 2010). Segundo o método adotado pelo SERAV, cada parte do mesmo casal/ex-casal fica em grupos distintos - as pessoas envolvidas no litígio são vinculadas a grupos em dia e horários diferentes. Por exemplo, se o homem participar no grupo de terça, a mulher participa no grupo de quinta, mas cada grupo possui outros homens e outras mulheres. Cada grupo é heterogêneo e dividido de forma a tentar equilibrar o número de homens e mulheres para ter aproximadamente a mesma quantidade de participantes de cada sexo, com cerca de 10 a 12 pessoas em cada encontro (Moreira \& Matta, 2006; Chaves \& Silva, 2010; Ghesti-Galvão et al., 2010; Santos, 2015).

As pessoas que fazem parte do mesmo processo são atendidas em grupos mistos diferentes. Peggy Papp (2002), uma importante terapeuta de família americana, denomina esse método de “cruzamento de casais", em que se observa uma maior efetividade para reflexão, troca de ideias e de escuta entre homens e mulheres no grupo. Moreira e Matta (2006) avaliam os benefícios do grupo misto:

Observamos que a separação da díade conflitiva em grupos de reflexão diferentes facilitou para as pessoas em situação de violência se "despirem de suas máscaras" e ouvirem o outro com empatia. Percebemos, ao longo do tempo, que as pessoas se sentiam mais à vontade por estarem reunidos com outros membros com histórico de violência do que com aqueles com os quais construíram uma relação conflitiva, o que, por sua vez, abriu possibilidades para repensar o padrão interacional violento (Moreira \& Matta, 2006, p. 227).

Essa divisão tem o intuito de promover melhores reflexões sobre a violência conjugal e sobre as questões de gênero, pois permite que um membro do casal/ex-casal escute com menor resistência pessoas de outro sexo - geralmente em situação equivalente ao/à do/a parceiro/a (Barker \& Nascimento, 2001; Chaves \& Silva, 2010; Ghesti-Galvão, Machado \& Costa, 2010; Moreira \& Matta, 2006; Ramos, 2013). Santos (2015) realizou um estudo de follow up com alguns homens e mulheres que participaram do Grupo Misto no SERAV. A maioria dos/as participantes da referida pesquisa percebeu o acompanhamento grupal como benéfico para iniciar o processo de superação da violência, para o melhor aproveitamento da passagem pelo contexto da Justiça e para sensibilização pessoal para dar continuidade em acompanhamentos em outras instituições.

\section{Núcleo de Atendimento às Famílias e Autores de Violência Doméstica - NAFAVD}

O NAFAVD é um serviço vinculado à Coordenação de Enfrentamento à Violência contra as Mulheres da Secretaria Adjunta de Políticas para as Mulheres da Secretaria de Estado de Políticas para as Mulheres, Igualdade Racial e Direitos Humanos - SEMIDH do Governo do Distrito Federal - GDF. Essa coordenação gerencia além do NAFAVD, outros importantes equipamentos públicos para o enfrentamento à violência: Casa Abrigo, Centros Especializados de Atendimentos às 
Mulheres (CEAM) e o Disque Direitos Humanos da Mulher do Distrito Federal. Essa coordenação trabalha em consonância com a Coordenação da Casa da Mulher Brasileira, que foi inaugurada recentemente e articula em um só local diversos serviços especializados de atendimento à mulher (Brasil/SPM, 2013; Distrito Federal, 2015).

O NAFAVD foi inaugurado em outubro de 2003 na cidade-satélite de Samambaia para atender a demanda das mulheres que saiam da Casa Abrigo e de seus parceiros. Atualmente, existem dez núcleos distribuídos em várias regiões do Distrito Federal: Brasília, Brazlândia, Ceilândia, Gama, Núcleo Bandeirante, Paranoá, Planaltina, Samambaia, Santa Maria e Sobradinho. O NAFAVD tem o objetivo de proporcionar acompanhamento psicossocial às famílias em situação de violência doméstica. Os encaminhamentos ao NAFAVD são realizados pela Casa Abrigo, Juizados Especiais Criminais, Juizados Especializados de Violência Doméstica e do Ministério Público (Aguiar, 2009; Distrito Federal, 2013, 2015; Figueira, 2011).

O NAFAVD oferece atendimento psicossocial para mulheres vítimas, homens autores e demais familiares por um período médio de seis meses. A equipe é composta por psicólogos/as, assistentes sociais e técnicos administrativos. O acompanhamento tem como objetivo favorecer o fortalecimento dos membros da família para facilitar a superação da violência (Aguiar, 2009; Figueira, 2011; Guimarães, 2009).

O acompanhamento psicossocial no NAFAVD é estruturado em várias etapas. A primeira é composta por uma sequência de atendimentos individuais/familiares para acolhimento, avaliação e intervenções iniciais com as pessoas. Esses atendimentos são seguidos de encaminhamento para grupos reflexivos de homens e de mulheres no próprio NAFAVD. A etapa grupal tem duração média de quatro meses - geralmente com 12 encontros. Os grupos são semanais, com duração média de uma hora e meia e são homogêneos - com participação exclusiva de homens ou de mulheres. Cada intervenção tem geralmente entre 10 a 12 pessoas. Os grupos são fechados do início ao fim do acompanhamento, ou seja, após o seu início não pode ser inseridos novos/as participantes. Ao final do acompanhamento grupal, alguns/mas participantes são convidados/as para atendimentos individuais para novas avaliações, intervenções e/ou sensibilização de encaminhamento para instituições da rede parceira do NAFAVD (Aguiar, 2009; Beiras, 2014; Figueira, 2011; Guimarães, 2009).

Alguns estudos (Aguiar, 2009; Figueira, 2011) reforçam a importância do atendimento psicossocial do NAFAVD aos homens autores de violência. Figueira mostrou que nem todos os homens que concluem o acompanhamento nesse núcleo saem totalmente consciente de seus atos, muitos continuam naturalizando a violência. No entanto, a autora mostra que eles consideram o NAFAVD como um espaço extremamente relevante de acolhimento e de solidariedade, justamente 
por ser um dos poucos ou único lugar em que homens autores podem refletir e compartilhar suas histórias e refletir sobre elas.

Aguiar (2009) corrobora a importância do trabalho do NAFAVD em uma pesquisa de follow up com homens autores que participaram do acompanhamento psicossocial nesse núcleo. Os homens perceberam a experiência do acompanhamento como benéfica por terem sido ouvidos e pela possibilidade de discutir e refletir sobre aspectos da dinâmica conjugal marcada pela violência e sobre aspectos mais amplos de suas vidas. Os participantes do estudo apontaram sensação de bemestar por serem acolhidos em ambiente grupal seguro e que possibilita a melhoraria da convivência familiar e conjugal, especialmente por propiciar reflexões sobre as dificuldades que os homens encontram para se relacionar com a parceira/ex-parceira e filhos, sobre o respeito entre homens e mulheres e sobre a necessidade da igualdade de gênero na relação conjugal. Os próprios participantes enfatizaram a necessidade de ter grupos semelhantes estendidos às comunidades e que possam incluir homens com demanda espontânea como meio de prevenir a violência.

Cada modalidade de intervenção grupal com homens em situação de violência possui suas vantagens e potencialidades, seja em grupo misto do SERAV ou em grupo composto exclusivamente por homens do NAFAVD. A pesquisa abrangeu participantes que estavam no acompanhamento psicossocial no SERAV e no NAFAVD para enriquecer os resultados a partir da percepção de homens inseridos em diferentes contextos de intervenção.

\section{Participantes}

Tivemos o intuito de trabalhar com homens autores em acompanhamento psicossocial no contexto da Justiça em momentos distintos do processo grupal nas duas instituições: SERAV e NAFAVD. O objetivo dessa escolha foi poder ampliar a possibilidade da análise das semelhanças e diferenças nas percepções e reflexões de homens de cada grupo, desde os homens que estavam no primeiro encontro até os que estavam chegando ao fim do acompanhamento psicossocial.

Acreditamos que participantes que estejam em inseridos em dinâmicas de violência mais graves podem se mostrar menos conscientes do impacto da violência conjugal em suas vidas. Podem também manifestar mais aspectos de negação, minimização e desresponsabilização da violência. A presença desses aspectos pode favorecer a instalação de anestesias relacionais e de duplo-vínculos na dinâmica conjugal e contribuir para a perpetuação da violência.

Os participantes foram divididos em duas etapas. A primeira etapa consistiu em um estudo piloto para fornecer subsídios para elaboração do questionário para a segunda etapa. Dessa forma, nessa etapa inicial foram escolhidos homens que estavam em acompanhamento psicossocial em apenas um dos postos do SERAV. Na segunda etapa, essa amostra foi ampliada para homens de vários postos dos SERAV e do NAFAVD. 


\section{Participantes da $1^{a}$ etapa}

Os participantes da etapa inicial da pesquisa foram 13 homens em situação de violência conjugal em acompanhamento psicossocial no SERAV/TJDFT, dentre os 21 convidados a participar do estudo. Escolhemos os homens que estavam participando do Grupo Misto - GM. O método de intervenção do SERAV contribuiu no sentido de aproveitar as vantagens e potencialidades da modalidade de intervenção grupal com homens em grupo misto.

Incluímos no estudo cinco mulheres que eram parceiras ou ex-parceiras dos homens participantes, que preencheram os questionários e que também compareceram no mesmo período ao Grupo Misto, mas em dias e horários diferentes dos seus ex/parceiros conforme o método do SERAV. Essa amostra complementar foi importante para termos mais elementos de análise das dinâmicas conjugais dos homens participantes, mas sem perder a priorização do estudo das masculinidades nesse trabalho. $\mathrm{O}$ intuito foi contemplar algumas especificidades do trabalho com homens em situação de violência conjugal e lidar com o desafio de ampliar as estratégias metodológicas em relação ao que foi trabalhado na pesquisa do mestrado.

A participação simultânea de homens e mulheres no mesmo grupo pode enriquecer as discussões sobre o livro e ampliar as perspectivas de como os homens manifestam anestesias relacionais e nomeiam suas vivências de violência conjugal. Além disso, a participação no grupo que inclui mulheres pode contribuir para reflexões importantes que não seriam possíveis em um grupo formado apenas por homens.

Escolhemos os participantes que estavam em acompanhamento psicossocial em um dos cinco postos do SERAV no período entre os anos de 2012 e 2013. Esse posto do SERAV localizase em uma das Regiões Administrativas do Distrito Federal. Nesse período da pesquisa, o método do SERAV nesse posto exigia que todos os homens participassem dos cinco encontros previstos. Foram utilizados dois critérios para seleção dos participantes:

- Critério de inclusão: todos os participantes deveriam estar em acompanhamento psicossocial no SERAV, ter sido encaminhado pela Justiça por estar em situação de violência conjugal e concordar com a participação na pesquisa;

- Critério de exclusão: os participantes que não sabiam ler e escrever não participaram da pesquisa. Esse critério foi imprescindível pelo fato do procedimento da pesquisa incluir a leitura do livro e o preenchimento do questionário. Para evitar o constrangimento de excluir a pessoa durante o procedimento, antes do convite para a participação na pesquisa, o pesquisador verificou a escolaridade de cada participante no Formulário de Acolhimento do SERAV e confirmou com a pessoa a capacidade de leitura. Somente foi feito o convite para aqueles que tiverem algum grau de escolaridade. 


\section{Participantes da $2^{a}$ etapa}

Os/as participantes da segunda etapa da pesquisa foram 45 homens em situação de violência conjugal em acompanhamento psicossocial no SERAV/TJDFT ou no NAFAVD/SEM/GDF dentre os 53 convidados a participar do método. Os participantes foram homens que estavam inseridos em seis diferentes grupos nesses serviços em agosto de 2015. Ao todo, participaram dessa etapa oito homens que estavam em acompanhamento no SERAV e 37 no NAFAVD. A diferença entre a quantidade de homens em cada instituição se deu pelo fato de os servidores da Justiça estarem em greve naquele período. O método misto do SERAV contribuiu para que menos homens participassem em cada dia, pois a outra metade do grupo é composta por mulheres.

Escolhemos os participantes que estavam em acompanhamento psicossocial em um dos cinco postos do SERAV e em quatro núcleos do NAFAVD de diferentes Regiões Administrativas do Distrito Federal. A ideia inicial era de incluir mais postos do SERAV, mas não foi possível devido à greve, pois apenas aquele posto manteve os grupos. O posto do SERAV dessa etapa foi diferente do posto da primeira etapa. Os homens estavam inseridos nos seis diferentes grupos nas seguintes datas:

- 12/8/2015: 3 participantes/SERAV;

- 13/8/2015: 12 participantes/NAFAVD;

- 19/8/2015: 5 participantes/SERAV;

- 20/8/2015: 5 participantes/NAFAVD;

- 24/8/2015: 12 participantes/NAFAVD;

- 25/8/2015: 8 participantes/NAFAVD.

Utilizamos dois critérios para seleção dos participantes. Os critérios de inclusão e exclusão dessa etapa sofreram pequenas adaptações para escolha dos homens:

- Critério de inclusão: todos os participantes deveriam estar em acompanhamento psicossocial no SERAV ou NAFAVD, terem sido encaminhados pela Justiça por estarem em situação de violência conjugal e concordarem com a participação na pesquisa. Os participantes dos grupos que não sabiam ou tinham dificuldade em ler e/ou escrever também participaram dessa etapa da pesquisa, pois o método foi adaptado para incluir essas pessoas e será descrito no tópico sobre procedimentos;

- Critério de exclusão: homens que informassem que não tinham interesse em participar da pesquisa teriam sua opção respeitada. Eles participariam da intervenção, mas os seus dados não seriam incluídos no estudo. 


\section{Instrumentos e Materiais}

Os instrumentos utilizados nessa pesquisa foram o livro "Mas ele diz que me ama" (Penfold, 2005/2006), dois questionários adaptados pelo pesquisador, ficha de evolução do Grupo Misto do SERAV, formulários de acolhimento do SERAV e do NAFAVD e "Controle de empréstimo dos livros".

\section{Livro "Mas ele diz que me ama"}

O livro "Mas ele diz que me ama: graphic novel de uma relação violenta" (Penfold, 2005/2006) é um instrumento simples, intenso e de grande impacto emocional para os/as leitores/as. Escolhemos utilizá-lo como instrumento potencializador de reflexões pelo fato de ele narrar uma biografia conjugal marcada pela violência e por abranger os principais elementos apontados na literatura como característicos de muitas dessas relações (Guimarães, 2009; Guimarães et al., 2007).

O livro foi escrito e ilustrado no formato de uma história em quadrinhos e é de fácil compreensão, o que diferencia essa obra em relação às outras sobre o tema de violência. Não se trata, portanto, de um livro teórico, acadêmico - ao mesmo tempo em que a história é narrada a autora estabelece um diálogo com o/a leitor/a, o que facilita a identificação com a história dos personagens (Guimarães, 2009).

O livro revela a relação conjugal vivida pela autora/personagem que perdurou por aproximadamente dez anos. A história é protagonizada por Rosalind Penfold (Roz) e Brian. Roz é uma mulher de 35 anos, solteira e empresária. Brian um viúvo e pai de quatro filhos. A narrativa mostra como Roz passou de uma mulher forte, decidida, feliz e bem-sucedida profissionalmente a esposa violentada e maltratada. Mostrou, também, como Brian foi ficando cada vez mais violento e não percebia o impacto de suas agressões. Por fim, o livro aponta o difícil processo de ruptura do relacionamento e de superação da violência (Guimarães et al., 2007; Penfold, 2005/2006).

\section{Questionários sobre o Livro "Mas ele diz que me ama"}

Dois questionários foram utilizados. Eles foram construídos com base no questionário que foi utilizado na pesquisa de mestrado (Guimarães, 2009) de acordo com os objetivos de cada etapa dessa pesquisa, destinada especialmente a conhecer dimensões da experiência de homens em relações marcadas pela presença de violências. Detalhamos a seguir os questionários utilizados nas duas etapas da pesquisa.

\section{Questionário $1^{a}$ Etapa}

$\mathrm{O}$ instrumento completo e em sua formatação original entregue aos participantes está no Anexo I. O primeiro questionário foi composto por 8 questões: 1) Qual foi o sentimento (ou 
sentimentos) que você teve ao ler este livro? 2) O que tem em comum na história do seu relacionamento e na história dos personagens do livro - Roz e Brian? 3) O que tem de diferente em sua história? 4) Na folha em anexo, marque com um " $X$ " nos pensamentos/sentimentos da Roz que são parecidos com os pensamentos que você teve. 5) Escolha 3 desses pensamentos que mais influenciaram em sua história. 6) Além dos pensamentos apresentados pela Roz, você teve outros que te impediram de pedir ajuda, de quebrar o ciclo de violência ou de sair do relacionamento? 7) A Roz resumiu a história dela com o título: "Mas ele diz que me ama...”. Qual seria o título da sua história? 8) Inspirado em sua história, complete o título do livro: Mas ele diz que me ama...

A questão quatro foi acompanhada por um material anexo - uma xérox das 35 anestesias que foram apresentadas pela autora em forma de quadrinhos nas duas contracapas do livro (Anexo II). Esses quadrinhos contêm o rosto, as expressões, os pensamentos e sentimentos da personagem. Esses pensamentos e sentimentos constituíram verdadeiras anestesias, que dificultavam ou impediam a sua saída do relacionamento e/ou pedido de ajuda (Ravazzola, 1997, 1998).

As anestesias apresentadas no livro estão listadas a seguir (os grifos são da autora - Penfold, 2005/2006): Talvez ele melhore...; Eu não deveria perdoar?; Será que outro homem seria melhor?; Sei que ele não fez de propósito...; Quem acreditaria em mim?; Ele pediu desculpas...; Não deveria ser paciente?; Quem disse que a vida é fácil?; Ele só tomou umas cervejas...; Não está bêbado nem nada...; Não bebe durante o dia.; É um grande homem...; E às vezes até bebe menos...; Nunca aprenderei a dizer a coisa certa?; Onde foi que eu errei?; Como posso abandonar as crianças?; Pode ser um transtorno de humor.; Talvez eu deva falar menos...; Talvez eu não seja sensível; Poderia ser muito pior...; Será que é mesmo tão ruim?; Talvez só esteja estressado; Ele jura que não vai acontecer de novo...; E se eu for o problema?; Sei que ele me ama...; Será alcoolismo?; E vinho no jantar; Não é uma pessoa má; Poxa, ele tem um bom emprego...; Então aguenta mais que os outros...; Então não tem como ser alcoólatra...; Se eu fosse mais compreensiva...; Se eu me esforçar mais...; Talvez eu seja sensível demais...; A culpa não é dele.

\section{Questionário $2^{a}$ Etapa}

Esse questionário foi desenvolvido a partir das respostas dadas pelos homens que participaram na primeira etapa. O método para sua construção está descrito no tópico "Procedimentos", discutido a seguir.

O instrumento completo e em sua formatação original entregue aos participantes está no Anexo III. O questionário foi composto por 8 questões: 1) Qual foi o sentimento (ou sentimentos) que você teve ao ler essa história? 2) O que tem de parecido na história de seu relacionamento e na história dos personagens do livro - Brian e Roz? 3) O que tem de diferente em sua história? 4) No anexo, marque com um " $X$ " nos pensamentos/sentimentos que são parecidos com os pensamentos 
que você teve. 5) Escolha 3 desses pensamentos que mais influenciaram em sua história. 6) Você teve outros pensamentos/sentimentos que te impediram de perceber as consequências da violência e/ou pedir ajuda 7) Um homem resumiu a história dele com a frase: "Será que o erro está em mim?". Qual é o título da sua história? 8) Inspirado em sua história, complete as frases abaixo: "Quem ama não bate, mas..." e "Fui amado, mas...".

A questão quatro foi acompanhada por um material anexo - uma xérox de 31 anestesias (Anexo IV) que foram apresentadas pelo personagem Brian do livro e pelos participantes da primeira etapa. Nós selecionamos as anestesias que representavam a negação, minimização e desresponsabilização da violência - esse processo de escolha das anestesias está descrito no capítulo dos resultados. Essas anestesias foram apresentadas no anexo de forma semelhante à primeira etapa, em formato de quadrinhos contendo o rosto, as expressões, os pensamentos e sentimentos do personagem Brian. Esses quadrinhos foram adaptados por um profissional de design gráfico a partir de solicitação do doutorando e com o intuito de manter a maior semelhança possível com o anexo do primeiro questionário e alcançar os objetivos dessa etapa.

As anestesias apresentadas nessa segunda etapa estão listadas a seguir: Ela é muito sensível; Eu ainda gosto dela; Não me ama, mas sempre precisa de mim; Mas ela é minha mulher; Ela era tudo pra mim; A gente bebia muito; Ela não precisava chamar a polícia; Me perdoa, não vai se repetir.; Eu era muito ciumento; Eu não vou perder minha família; Pode ser paciente comigo?; Se você largar o seu emprego, terá mais tempo para nós.; Quero que nós dois viremos um só...; Não vai acontecer de novo... Eu juro!; Eu não quero que você fale com os vizinhos!; Eu fiz mesmo essas coisas? Não me lembro...; Nosso amor não significa nada para você?; Confie em mim, amor. Sei o que é melhor para você.; Não acredito que magoei você desse jeito...; Eu te amo... Nunca quis magoar você...; Mas ela sempre diz a coisa errada.; Não desista de nós logo agora, meu amor...; Não jogue fora nosso amor.; Nunca percebe meu estado de espírito...; Você precisa me dar mais uma chance... Por favor!; Você não passa de uma vadia!; Tudo vai mudar, eu juro! Não posso perder você...; Você tem que aprender a se cuidar melhor!; Se você depuser contra mim... Posso até ser preso!; Pense nas crianças.; Você nunca vai encontrar um homem que tenha mais amor para dar...

A questão sete e oito também foram adaptadas a partir das respostas dos participantes da primeira etapa: 7) Um homem resumiu a história dele com a frase: “Será que o erro está em mim?”. Qual é o título da sua história? 8) Inspirado em sua história, complete as frases abaixo: "Quem ama não bate, mas..." e "Fui amado, mas...". Nós selecionamos essas frases dentre os diversos títulos que melhor representavam a negação, minimização ou desresponsabilização pela violência - o critério de escolha desses títulos está descrito no capítulo dos resultados.

O pesquisador obteve junto à editora a liberação para utilização e publicação das imagens 
constantes no livro. A confirmação sobre a possibilidade de utilizá-las para fins de pesquisa foi obtida por e-mail. A editora colaborou com a realização desse estudo com a doação de três exemplares do livro.

\section{Ficha de evolução do Grupo Misto do SERAV}

Nós utilizamos essa ficha na primeira etapa desse estudo para incluir nos resultados um breve panorama da história e para contextualizar algumas dimensões da dinâmica relacional de cada participante de modo a ajudar na compreensão de suas respostas ao questionário sobre o livro. Essa ficha de evolução foi útil para apresentarmos alguns dados relevantes constantes no processo e nas anotações dos/as técnicos/as durante toda a participação no Grupo Misto e, especialmente, no encontro referente à reflexão grupal sobre o livro.

A ficha de evolução do Grupo Misto (Anexo V) é um instrumento utilizado pelos/as técnicos/as do SERAV para anotar os principais dados referentes à participação dos homens e das mulheres em cada encontro grupal. Uma ficha é criada para cada participante e serve como base para elaboração do parecer técnico ao final do acompanhamento psicossocial no SERAV.

Esse instrumento é composto por um cabeçalho e espaço para evolução de cada atendimento. $\mathrm{O}$ cabeçalho contém um resumo dos principais dados constante no processo judicial: nome das partes, juizado que encaminhou, número do caso no SERAV, dia da semana do GM e um resumo dos fatos. O espaço para evolução é composto por cinco campos para os/as técnicos/as resumirem as informações do/a participante em cada encontro. Os campos de evolução têm um espaço para inserir a data do atendimento e o nome dos técnicos/as responsáveis pelo GM. Ao final da ficha de evolução, há um campo para marcar se a pessoa conseguiu fazer algumas reflexões sobre a dinâmica conjugal e sobre possível encaminhamento - se a pessoa aceitou, pediu ou negou a proposta de encaminhamento e para onde foi encaminhada.

\section{Formulários de acolhimento do SERAV e do NAFAVD}

Os formulários de acolhimento do SERAV e do NAFAVD são preenchidos pelos profissionais de cada serviço para todas as pessoas encaminhadas ao acompanhamento psicossocial. Esses formulários foram incluídos como instrumentos da pesquisa com o objetivo de fornecer dados sociodemográficos dos participantes. A sua aplicação permitiu a compreensão e a contextualização da situação socioeconômica; do relacionamento conjugal; da rede de apoio social e do histórico da violência conjugal dos homens participantes do estudo.

\section{Controle de Empréstimo do Livro}

Esse instrumento de "Controle de Empréstimos" (Anexo VI) foi utilizado na primeira etapa para diminuir o risco de não devolução do livro "Mas ele diz que me ama". Esse controle é 
relevante para evitar a perda do livro, ainda mais que ele encontra-se esgotado nas livrarias.

\section{Procedimentos}

Os procedimentos metodológicos foram compostos pelas estratégias de coleta e de análise de dados, bem como os cuidados éticos. Esses passos estão descritos a seguir.

\section{Estratégias de coleta de dados}

Os grupos para reflexão sobre o livro foram realizados em duas etapas. Nas duas etapas tivemos o objetivo de favorecer a manifestação de anestesias relacionais e nomeação da dinâmica conjugal de forma indireta e gradual por meio de estímulos - dos personagens do livro e/ou dos participantes da etapa anterior.

$1^{a}$ Etapa

$\mathrm{Na}$ primeira etapa, iniciamos com a apresentação das anestesias e títulos presentes na história da personagem/autora do livro para que os participantes identificassem e comparassem com alguns aspectos semelhantes ou diferentes em suas vivências - a partir de estímulos apresentados por uma mulher vítima de violência. Essa etapa serviu como um estudo piloto para fornecer elementos para construção do questionário para a segunda etapa da pesquisa, mas também foi importante para termos resultados preliminares acerca do método utilizado.

Essa primeira etapa da pesquisa foi realizada nos anos de 2012 e 2013 e teve como objetivo refletir sobre anestesias relacionais e nomeação das dinâmicas relacionais marcadas pela violência conjugal pelos/as participantes a partir de estímulos apresentados por uma mulher vítima de violência. O procedimento foi adotado em cinco Grupos Mistos distintos, ou seja, com a participação de diferentes participantes em cada grupo. As datas de cada coleta foram: 30/4/2012, $7 / 11 / 2012,12 / 11 / 2012,10 / 6 / 2013$ e 19/6/2013. Incluímos na pesquisa os 21 casos nos quais os homens aceitaram participar do procedimento e foram aplicados a estratégia metodológica de utilização do livro "Mas ele diz que me ama" com homens autores de violência nesse período. Desse total, 13 questionários foram devidamente preenchidos pelos homens em atendimentos grupais no SERAV.

Tivemos o objetivo de identificar os sentimentos despertados nos homens pela leitura do livro; compreender os elementos que os participantes identificaram como semelhantes ou diferentes ao compararem suas histórias pessoais com as do casal protagonista do livro; refletir sobre as anestesias que os participantes do grupo identificam como possíveis em suas próprias histórias que os influenciaram na instalação e na manutenção da violência, bem como na permanência no relacionamento conjugal com violência; conhecer como os homens percebem e/ou nomeiam a sua 
vivência conjugal utilizando o título do livro como elemento estimulador.

A coleta de dados foi realizada no ambiente do próprio acompanhamento psicossocial do SERAV nos atendimentos de Grupos Mistos conduzidos pelo doutorando/pesquisador. O doutorando realizou a coleta de dados em diversos grupos quando era escalado para ser parte da dupla de profissionais do serviço responsáveis pela condução dos grupos. A coleta de dados foi realizada em dois encontros para cada grupo:

- $\mathbf{1}^{\mathbf{o}}$ encontro: 1) Convite dos participantes e explicação do procedimento; 2) Leitura e assinatura do Termo de Consentimento Livre e Esclarecido - TCLE (Anexo VII); 3) Empréstimo de um exemplar original do livro (Penfold, 2005/2006); e 4) Entrega do questionário sobre o livro para leitura e preenchimento individual durante a semana.

- $\quad \mathbf{2}^{\mathbf{o}}$ encontro: 1) Discussão em grupo sobre o livro e as perguntas do questionário; e 2) Recolhimento do questionário e TCLE preenchidos.

O intervalo de tempo entre o primeiro e o segundo encontro para cada grupo foi de uma semana. O segundo encontro teve duração média de uma hora e trinta minutos. O procedimento de condução desse segundo encontro foi padrão para todos os grupos: a dinâmica foi iniciada a partir de uma pergunta sobre a impressão geral e sentimentos dos homens e das mulheres ao ler o livro, seguida pela reflexão grupal de cada tópico do questionário.

A reflexão sobre os aspectos que os participantes consideravam comuns e diferentes em suas vivências quando comparados à história dos personagens do livro foi o foco desse encontro. Em seguida, estimulamos reflexões acerca das anestesias relacionais de forma indireta e gradual. O processo teve inicio com a apresentação das anestesias presentes na história da personagem do livro, que estavam listadas no Anexo II.

Os participantes foram convidados, então, a indicarem quais seriam as anestesias que poderiam estar presentes em suas vivências dentre as anestesias apresentadas pela personagem/autora do livro. Os homens escolheram as anestesias que identificam como semelhante à sua história. Por último, estimulamos a percepção e/ou nomeação das próprias histórias a partir do título do livro para verificar se os homens manifestariam alguns aspectos que indicariam critérios de duplo-vínculos de suas dinâmicas conjugais marcadas pela violência.

Esse procedimento foi adotado com todos/as os/as participantes dos grupos. Homens e mulheres foram convidados/as a ler o livro e preencher o questionário durante a semana e a participar da reflexão grupal no segundo encontro. Como o foco desse trabalho é com os homens autores de violência, não consideramos os questionários preenchidos pelas mulheres. Foram analisados apenas os questionários das cinco mulheres que eram parceiras ou ex-parceiras dos homens participantes, que também participaram da estratégia proposta no mesmo período que eles. 


\section{$2^{a}$ Etapa}

$\mathrm{Na}$ segunda etapa, a reflexão sobre o livro também teve como objetivo identificar as anestesias relacionais e nomeação da dinâmica relacional marcada pela violência por meio dos relatos da vivência dos próprios participantes. Essa reflexão se deu a partir dos estímulos que foram apresentados pelo Brian - personagem do livro - e pelos participantes da primeira etapa, ou seja, por meio de estímulos que foram apresentados por outros homens autores de violência.

A segunda etapa foi realizada em agosto de 2015 e teve como objetivo refletir sobre as anestesias relacionais e nomeação das dinâmicas conjugais pelos participantes - homens em acompanhamento psicossocial no SERAV ou NAFAVD - a partir de estímulos que foram apresentados por outros homens autores de violência - do personagem do livro que representou um homem autor de violência e pelos participantes da primeira etapa. Ao todo foram seis encontros em que a proposta metodológica foi aplicada. As datas dos encontros foram: 12, 13, 19, 20, 24 e 25 de agosto de 2015 .

A coleta de dados ocorreu nas dependências de um dos postos do SERAV e de quatro núcleos distintos do NAFAVD. O pesquisador entrou em contato com a gerência e equipe desses serviços para confirmar a autorização do aceite institucional e combinar os procedimentos específicos em cada instituição. A ideia inicial seria o comparecimento do pesquisador no grupo apenas para convidar os participantes para um grupo exclusivo para a coleta de dados em outro dia e horário ou após o grupo do SERAV ou NAFAVD. No entanto, houve o acordo de as instituições cederem a metade (SERAV) ou um encontro grupal inteiro (NAFAVD) do acompanhamento psicossocial de cada serviço ou núcleo como forma de aumentar a chance de participação dos homens na pesquisa e de a equipe aprender esse procedimento de intervenção. Os procedimentos de coleta aconteceram nas salas de grupos destes serviços e foram realizados no ambiente do próprio acompanhamento psicossocial do NAFAVD e após o atendimento grupal no SERAV.

No NAFAVD, o pesquisador participou de um encontro grupal do próprio acompanhamento psicossocial e conduziu a coleta de dados em conjunto com os/as profissionais do serviço. $\mathrm{O}$ fato de ser um grupo exclusivo de homens favoreceu a participação do pesquisador em todo encontro grupal.

No SERAV, o pesquisador compareceu ao final da primeira metade do encontro grupal no serviço, que terminou uma hora mais cedo. O doutorando convidou os homens interessados para a coleta de dados da pesquisa. Como o método do grupo é misto, o procedimento ocorreu na segunda metade do horário reservado ao grupo, para que as mulheres pudessem ser liberadas e contar apenas com a participação dos homens. 
Nos dois casos, foi enfatizada a voluntariedade e todas as outras garantias éticas dos participantes, conforme será discutido mais detalhadamente no tópico "Cuidados Éticos" a seguir. Ressaltamos a importância de se realizar a coleta de dados no contexto do acompanhamento psicossocial ou, pelo menos, no mesmo ambiente físico desses serviços. Isso contribuiu para maior facilidade no acesso aos participantes da pesquisa e para que se, por algum acaso, acontecesse algum problema emocional após a pesquisa, tal problema pudesse ser trabalhado no próprio estudo/acompanhamento psicossocial ou ser encaminhado para algum acompanhamento em instituição da Rede Social parceira do SERAV ou NAFAVD.

O procedimento foi adaptado para realizar toda a coleta em um encontro grupal nessa etapa. $\mathrm{Na}$ primeira etapa da pesquisa, solicitamos aos participantes a leitura de todo o livro "Mas ele diz que me ama" durante o período de uma semana entre os dois encontros grupais. Para a segunda etapa, providenciamos um resumo do livro.

Esse resumo teve o objetivo de contemplar os principais fatos da história dos personagens e possibilitar a leitura pelos participantes em menos tempo - em torno de 20 minutos - para que o procedimento pudesse ser realizado em um encontro apenas. Nós privilegiamos os momentos do livro em que o personagem Brian - que representa o homem autor de violência - tem maior evidência na história. Nós escolhemos os momentos de início do relacionamento, da instalação da violência, de ocorrência de diversos tipos de agressão e de reconquista, dos vários ciclos de violência, etc.

As páginas selecionadas foram: 38 a 41, 70 a 74, 77, 81, 82, 92 a 95, 100 a 102, 106, 113, 115 a 117, 150 a 155, 162 a 165, 182, 183, 188 a 199, 204 a 211, 214, 215, 217, 251. Assim, esse resumo permite a leitura da história em menos tempo, mas sem deixar de contemplar os principais aspectos da vivência do casal protagonista, que vão muito além das agressões. O pesquisador disponibilizou 12 xérox desse material - cada um foi encadernado e organizado em 20 folhas, cada folha com duas páginas do livro - com o único objetivo de ser utilizado nesse estudo.

O intuito dessa adaptação foi ter uma maior garantia da leitura do livro pelos participantes, auxiliar os homens que não sabiam ou tinham dificuldade em ler o livro e/ou preencher o questionário e ter mais agilidade na coleta de dados. Como não tivemos o objetivo de comparar os dados da primeira e segunda etapa, consideramos que essas alterações não comprometem os resultados desse estudo. O procedimento ocorreu da seguinte forma e sequência:

1) Convite dos participantes e explicação do procedimento;

2) Leitura e assinatura do Termo de Consentimento Livre e Esclarecido - TCLE (Anexo VII);

3) Leitura grupal do resumo do livro (Penfold, 2005/2006); 
4) Entrega do questionário para preenchimento individual durante o grupo;

5) Discussão em grupo sobre o livro e as perguntas do questionário.

6) Recolhimento do questionário e do TCLE preenchidos.

Esse procedimento teve duração média de uma hora e trinta minutos no NAFAVD e de uma hora no SERAV. O convite aos participantes e a aplicação do TCLE demoraram em média 15 minutos. A leitura do resumo do livro durou em torno de 20 minutos. O preenchimento do questionário levou em média 15 minutos. O restante do tempo foi dedicado à reflexão grupal sobre o livro e as respostas ao questionário, que teve maior duração no NAFAVD devido ao maior tempo disponível para a coleta de dados.

A condução desse encontro foi padrão para todos os grupos em cada núcleo do NAFAVD e no posto do SERAV:

- Leitura do resumo do livro: primeiro foi realizada a leitura do resumo em grupo e em voz alta por um ou mais participantes, que foram revezando a leitura. Essa leitura conjunta facilitou o acompanhamento dos outros participantes, inclusive os que não sabiam ou tinham dificuldade de leitura, que puderam acompanhar a história por meio das ilustrações do livro.

- Preenchimento do questionário: em seguida, os participantes foram convidados a preencher o questionário individualmente. Alguns homens foram ajudados pela equipe no preenchimento das respostas, seja para entender melhor as perguntas ou para auxiliar os que tinham dificuldade de escrita. A equipe foi orientada a tomar cuidado para transcrever exatamente o que o participante ditava, sem alterar ou influenciar a sua resposta.

- Dinâmica de reflexão sobre o livro: com procedimento semelhante ao que ocorreu na primeira etapa. Ela foi iniciada a partir de uma pergunta sobre a impressão geral e sentimentos dos homens ao ler o livro, seguida pela reflexão grupal de cada tópico do questionário.

Realizamos a gravação de voz das reflexões sobre a leitura do livro e das respostas às perguntas do instrumento no segundo encontro de cada grupo. As gravações foram feitas mediante a autorização prévia - verbal e por escrito no TCLE - de todos os participantes. Posteriormente, foram transcritas pelo próprio pesquisador. A transcrição do material serviu como um complemento para ilustrar e enriquecer as informações obtidas por meio do questionário.

Cabe apontar que o pesquisador fez uma breve reunião com a equipe antes e após o grupo, no intuito de explicar, planejar e organizar o material para a intervenção e depois processar a intervenção realizada. Essa reunião durou 30 minutos em média. Após o procedimento grupal, foi 
realizada uma avaliação do grupo, dos elementos positivos e as dificuldades encontradas. Nesse momento, o pesquisador verificou com a equipe quais eram os casos graves e de alto risco.

Incluímos nos resultados um breve panorama dos casos mais graves para contextualizar a história de cada um desses participantes e ajudar na compreensão de suas respostas - tendo o cuidado de manter o sigilo de sua identidade. Apresentamos alguns dados relevantes no processo e nas anotações dos/as técnicos/as durante a participação dos homens nos grupos do SERAV e do NAFAVD. Para isso, enfatizamos alguns fatos de destaque para favorecer essa contextualização.

As dimensões das dinâmicas relacionais são comumente identificadas pelos profissionais por meio de relatos das mulheres e homens atendidos. Uma vez que eles e elas, mesmo após a denúncia, tendem a negar, minimizar e/ou a se desresponsabilizar pelo processo de violência vivido, na maioria das vezes são os profissionais que reconhecem e apontam a ocorrência das anestesias e os paradoxos da relação. As mulheres e os homens nem sempre estão preparados/as para reconhecêlos/as. Esse processo de identificação pode levar muito tempo e mesmo assim não ser eficaz em promover o reconhecimento dessas anestesias e dos duplo-vínculos da relação por parte das mulheres e homens autores e/ou vítimas da violência.

O diferencial dessa pesquisa-intervenção é oferecer o acesso a um material que tem o potencial de ajudar na identificação, nomeação e/ou reflexão sobre as anestesias relacionais e critérios de duplo-vínculos por parte dos próprios homens participantes e não apenas pelos/as profissionais. Esse processo de reflexão ocorreu de forma indireta e gradual. A dinâmica grupal teve inicio com a leitura das anestesias nomeadas pelos personagens do livro ou pelos participantes da etapa anterior, que serviram como estímulos para facilitar a manifestação de anestesias pelos homens.

$\mathrm{Na}$ etapa seguinte foram identificadas as anestesias presentes nas histórias dos homens participantes. Essas anestesias foram escolhidas dentre as anestesias apresentadas nos desenhosestímulos. Posteriormente, os homens selecionaram as três anestesias que consideraram mais influentes em suas próprias histórias. Por último, eles acrescentam as anestesias advindas de sua experiência e que não estavam listadas no estímulo fornecido.

Esse processo de aproximação gradativa ajuda o participante a ir reconhecendo dimensões de sua própria experiência e a ir lidando com seus sentimentos - dor, medo, ansiedade, angustia, raiva, tristeza, perda. Tal fato, aliado à identificação com os personagens e com os/as outros/as participantes do grupo cria um contexto propício à nomeação e ruptura do pacto de naturalização da violência, de silêncio e de autoexpiação.

Acreditamos que os dados obtidos na presente pesquisa podem contribuir para avançar a análise e compreensão de duas dimensões importantes da dinâmica relacional violenta - as 
anestesias e os processos duplo-vinculares. Por fim, propomos nesse estudo uma estratégia metodológica com potencial de utilidade como método de pesquisa e como uma proposta adicional de intervenção clínica com homens em situação de violência conjugal.

\section{Estratégias de análise de dados}

A natureza qualitativa da pesquisa nos levou a privilegiar a análise de conteúdo das respostas aos questionários preenchidos pelos participantes (Bardin, 2004; Bauer, 2002; Minayo, 1998, 2001; Seidl de Moura \& Ferreira, 2005). A análise de conteúdo dessas respostas priorizou a criação de categorias a partir do conteúdo trazido pelos participantes com base nas respostas ao questionário e na revisão de literatura. As categorias podem ser elaboradas por meio do estabelecimento de conexões e relações entre as diversas respostas trazidas pelos homens (Bardin, 2004; Bauer, 2002; Romeu, 2001). Silveira et al. (2009) defendem que as categorias não podem ser estanques e nem excludentes - elas podem e devem apresentar as diversas tensões e correlações presentes na experiência em vários momentos.

Minayo (1998, 2001) afirma que nas pesquisas qualitativas, as categorias devem ser analisadas até alcançarem a saturação dos seus significados coletivos. Concordamos com diversos pesquisadores (Alves et al., 2012; Bardin, 2004; Silveira et al., 2009) que as respostas expressas pelos homens participantes são construídas coletivamente. Nesse sentido, esses estudos apontam que valores, crenças, ideias e significados enunciados/nomeados por esses homens podem circular em diferentes contextos.

As respostas individuais ao questionário seguidas da reflexão grupal podem ajudar a dar sentido à experiência vivida na relação e auxiliar na construção de significados que dão base ao seu entendimento enquanto sujeito e como homens autores de violência conjugal. Nesse contexto, as respostas podem ser ferramentas importantes para dar inteligibilidade aos principais acontecimentos que marcam a experiência relacional e que levaram esses homens a passarem pelo contexto de justiça. Os homens podem assim ter um espaço para articular os significados de sua experiência e revelar aspectos importantes de suas subjetividades e de suas relações (Beiras, 2012; Beiras \& Cantera, 2012).

No intuito de complementar as respostas ao questionário dos participantes da segunda etapa, realizamos a gravação da parte final da reflexão de cada grupo no intuito de registrar breves narrativas dos homens autores de violência sobre o livro e o método proposto. Beiras e Cantera (2012) definem uma narrativa como "una historia breve y temporalmente ordenada que responde a pregunta de un entrevistador o una conversación extendida que se organiza por caminos complejos, flashbacks o un episodio" (Beiras \& Cantera, 2012, p. 254)

Narrativas podem ajudar na manifestação de aspectos importantes da subjetividade dos 
homens autores de violência conjugal (Beiras, 2012; Beiras \& Cantera, 2012). Dessa forma, consideramos ser relevante explorar as percepções dos próprios homens sobre a dinâmica conjugal, suas correlações com a violência e os signos de masculinidade que perpassam suas vivências familiares, comunitárias e sociais. Buscamos também conhecer as diversas formas com que esses homens se relacionam com o acompanhamento psicossocial na Justiça, a partir de seu lugar de sujeito de direitos. Nesse sentido, esse contexto pode se tornar um lugar privilegiado para identificação dos diversos aspectos que favorecem o processo de naturalização da violência conjugal (Maciel \& Barbosa, 2010; Silveira et al., 2009).

\section{Cuidados éticos}

A adoção de postura ética ativa e crítica constituíram as bases dessa pesquisa. Os princípios e as regras da legislação pertinente foram plenamente respeitados (Guareschi, 2000; Medeiros, 2002). As principais referências éticas desse estudo foram o Código de Ética Profissional do Psicólogo, a resolução CFP 016/2000 (CFP, 2000), a resolução 196/96 do Conselho Nacional de Saúde (CNS, 1996) e as orientações da Organização Mundial da Saúde sobre pesquisas em situação de violência doméstica e familiar (OMS, 2001).

Alguns aspectos mereceram cuidados éticos especiais por se tratar de pesquisa sobre violência conjugal no contexto da justiça. Dentre esses aspectos estão: a garantia de sigilo absoluto da identidade dos participantes; o cuidado na manipulação e divulgação dos resultados; evitar no processo da pesquisa a revitimização e a emergência de novos conflitos conjugais; apresentar devolutiva dos resultados às instituições que permitiram a realização da pesquisa no contexto de seus acompanhamentos psicossociais.

Uma vez que a pesquisa foi realizada com homens em situação de violência, houve o respeito pleno ao parágrafo $3^{\circ}$, do art. $3^{\circ}$, da resolução ${ }^{\circ}$ 016/2000 do CFP, ao não considerar como pesquisa de risco mínimo e ao avaliar se algum dano foi causado ao término da participação de cada homem (CFP, 2000). Ressaltamos, assim, a importância de termos realizado a coleta de dados no contexto do acompanhamento psicossocial do SERAV e do NAFAVD. Isso contribuiu para que tivéssemos maior facilidade no acesso aos participantes da pesquisa e para que, se acontecesse algum problema emocional após a pesquisa, esse pudesse ser trabalhado no próprio contexto do acompanhamento psicossocial. Esse procedimento foi importante para limitar e remediar qualquer possível sofrimento, evitar aumento do risco de violência e para facilitar que a pessoa pudesse ser encaminhada para algum acompanhamento na Rede Social parceira do SERAV/NAFAVD.

Outro aspecto importante foi a ênfase na voluntariedade dos participantes. Destacamos, especialmente, o fato de que a participação na pesquisa não interferiria em nada no possível processo judicial e/ou acompanhamento psicossocial. 
Realizamos o levantamento de alguns riscos e/ou dificuldades que tinham possibilidade de surgir no decorrer da coleta de dados dessa pesquisa. Estes riscos e dificuldades foram discutidos previamente em reunião grupal de orientação de doutorado no intuito de identificá-los e preveni-los. Os riscos e as estratégias imaginados para superá-los são apresentados a seguir:

1. Risco / Dificuldade: resistência dos participantes em relatar a vivência pessoal de violência conjugal.

\section{Estratégia(s):}

1.1. Explicação dos objetivos da pesquisa para mostrar a importância de realização de estudos na área, mesmo que os ganhos não sejam diretos para os participantes. Eles foram informados sobre a garantia de voluntariedade e a possibilidade de desistência da participação a qualquer momento;

1.2. Garantia do compromisso ético da pesquisa, principalmente quanto ao sigilo da identidade dos participantes.

2. Risco / Dificuldade: problemas emocionais que podem surgir após a entrevista, tais como angústia e ansiedade pelo fato de relembrar e refletir sobre as vivências violentas.

Estratégia(s):

2.1. Leitura e explicação prévia do TCLE;

2.2. Disponibilização de uma via do TCLE para o participante contendo os contatos do pesquisador e da orientadora;

2.3. Informação fornecida pelo pesquisador - verbal e por escrito no TCLE - de que no caso de surgir qualquer problema com algum participante em decorrência de qualquer procedimento da pesquisa, eles poderiam entrar em contato com o pesquisador a qualquer momento, mesmo após o término da pesquisa e/ou do acompanhamento psicossocial;

2.4. Os participantes estavam em acompanhamento psicossocial na instituição onde a pesquisa foi realizada. Em caso de algum problema emocional após a pesquisa, o mesmo poderia ser trabalhado no próprio acompanhamento psicossocial para limitar e remediar qualquer dano causado, de acordo com o parágrafo $3^{\circ}$, do art. $3^{\circ}$, da resolução $n^{\circ}$ 016/2000 do CFP; ou, caso necessário, a pessoa poderia ser encaminhada para algum acompanhamento na Rede Social parceira do SERAV e do NAFAVD;

2.5. Devolutiva dos resultados aos participantes ao fim da pesquisa.

Apesar da possibilidade de ocorrência dos possíveis riscos discutidos acima, entendemos que eles foram mínimos quando comparados aos possíveis benefícios em função da participação nesta pesquisa, ainda mais que foram adotadas as devidas estratégias para evitá-los ou minimizálos. O fato é que foi oferecido aos participantes um espaço que facilitou a reflexão sobre o seu 
relacionamento conjugal, sobre as dificuldades em reconhecer ou lidar com a violência. A participação na pesquisa pôde contribuir para a reflexão sobre o impacto das agressões em suas vidas e nas vidas das outras pessoas envolvidas; sobre as anestesias e os processos duplo-vinculares que favorecem a sua manutenção; e sobre como esses homens nomeiam e percebem o seu relacionamento.

Além dos possíveis benefícios individuais, essa pesquisa pode ajudar na ampliação da compreensão dos fatores que levam homens autores de violência a cometerem a violência, negarem ou minimizarem o impacto de seus atos e permanecerem na relação marcada pela violência. Essa proposta de trabalho pode contribuir para a melhoria dos serviços psicossociais com o auxílio de pesquisas na área da Psicologia Clínica de modo a aprimorar e consolidar estratégias de intervenção voltadas aos homens, às mulheres e casais envolvidos na conjugalidade com violência.

Uma postura ativa e crítica foi adotada em todas as etapas da pesquisa, desde a elaboração do projeto, contato com os/as participantes e redação da tese. De acordo com regras e orientações de Seidl de Moura e Ferreira (2005) sobre os cuidados éticos, o projeto foi submetido e aprovado

pelo Comitê de Ética em Pesquisa - CEP do Instituto de Ciências Humanas - IH da Universidade de Brasília - UnB, com protocolo da aprovação de número 922.834. 


\section{Capítulo 5}

\section{Resultados: Duplo-vínculos e anestesias relacionais na perspectiva de homens}

É triste ver meu homem
Guerreiro menino
Com a barra do seu tempo
Por sobre seus ombros
Eu vejo que ele berra
Eu vejo que ele sangra
A dor que tem no peito
Pois ama e ama...
E sem o seu trabalho
O homem não tem honra
E sem a sua honra
Se morre, se mata

(Música: Um homem também chora / Guerreiro Menino - Gonzaguinha)

A partir da utilização de uma abordagem sistêmica feminista (Angelim, 2004, 2009; Diniz, 2011; Pondaag, 2003, 2009; Ravazzola, 2007) e de uma perspectiva relacional de gênero (Debert \& Gregori, 2008; Gregori, 1993; Grossi, Minella \& Losso, 2006; Medrado, 2009; Medrado \& Lyra, 2014; Oliveira \& Gomes, 2011; Silveira, Medrado \& Rodrigues, 2009; Teixeira, 2009), essa pesquisa teve o objetivo de identificar como homens autores de violência conjugal que participaram da pesquisa como parte de uma intervenção psicossocial na Justiça manifestam indícios de anestesias relacionais e de dimensões duplo-vinculares da dinâmica conjugal, por meio da leitura e reflexão em grupo do livro: "Mas ele diz que me ama" (Penfold, 2005/2006). A compreensão de anestesias relacionais e de características de duplo-vínculos é importante por esses serem processos presentes em muitas dinâmicas de violência conjugal que levam à minimização, negação, desresponsabilização e não nomeação das violências.

Os principais resultados das duas etapas do estudo serão apresentados nesse capítulo. $\mathrm{Na}$ primeira etapa, iniciamos com a apresentação das anestesias e títulos presentes na história da personagem/autora do livro para que os participantes identificassem e comparassem com aspectos semelhantes ou diferentes presentes em suas vivências de violência. Essa etapa serviu como um estudo piloto para fornecer elementos para construção do questionário para a segunda etapa da pesquisa.

Na segunda etapa, a reflexão sobre o livro também teve como objetivo identificar as anestesias relacionais e favorecer a nomeação da dinâmica relacional violentas por parte da vivência dos próprios participantes. No entanto, essa reflexão se deu a partir dos estímulos que foram apresentados pelo Brian - personagem que representou o homem autor no livro - e pelos participantes da primeira etapa, ou seja, por meio de estímulos que foram apresentados por outros homens autores de violência. Nas duas etapas tivemos o objetivo de favorecer a manifestação de 
anestesias relacionais e a nomeação da dinâmica conjugal de forma indireta e gradual por meio de estímulos - dos personagens do livro e/ou dos próprios participantes da etapa anterior.

Cabe ressaltar que não tivemos o objetivo de comparar os dados da primeira e segunda etapa. Iniciamos a apresentação dos dados com a contextualização das conjugalidades dos homens participantes nas duas etapas, por meio das características sociodemográficas e da dinâmica relacional. Mostramos também os impactos da história do livro nas vivências dos homens autores de violência. Por último, apresentamos algumas complementaridades das vivências de homens e mulheres dos casos em que os dois membros do casal ou ex-casal participaram dos procedimentos dessa pesquisa.

\section{Contextualização das conjugalidades dos homens participantes}

Apresentamos uma breve contextualização de algumas informações relevantes dos participantes das duas etapas para melhor entendimento de suas respostas ao questionário utilizado nessa pesquisa. Iniciamos com um resumo sobre a participação dos homens ao procedimento e, em seguida, mostramos alguns aspectos relacionados às conjugalidades dos homens participantes por meio das características sociodemográficas e da dinâmica relacional.

A Tabela 6.1 mostra algumas informações de todos os casos em que foram aplicados a estratégia metodológica proposta nesse trabalho na primeira etapa, que foi importante para dar motivação para pensar nessa pesquisa de doutorado. Detalhamos o número de pessoas convidadas a participar da proposta, o sexo e a quantidade de homens e mulheres que participaram ou não. Essa amostra foi realizada em um dos cinco postos do SERAV nos anos de 2012 e 2013.

Tabela 6.1

Adesão dos Casos que Participaram da Etapa I - 2012 e 2013

\begin{tabular}{ccccc}
\hline Ano & Sexo & Convidados & Participaram & Não Participaram \\
\hline \multirow{2}{*}{2012} & M & 12 & 6 & 6 \\
& F & 14 & 12 & 2 \\
\hline \multirow{2}{*}{2013} & M & 8 & 7 & 1 \\
& F & 7 & 7 & 0 \\
\hline \multirow{2}{*}{ Total } & & 41 & 32 & 9 \\
\hline
\end{tabular}

Nota. As siglas M e F significam "Masculino" e "Feminino", respectivamente

A estratégia da pesquisa foi aplicada em 26 pessoas no ano de 2012 e em 15 pessoas em 2013. Dentre os 20 homens que foram convidados e aceitaram participar da proposta, 13 responderam o questionário e participaram do outro encontro grupal, sete não retornaram para o encontro na semana seguinte de discussão grupal a respeito da história do livro e das respostas ao questionário. Todos justificaram a ausência e devolveram o livro posteriormente. Cinco homens que faltaram alegaram problema no trabalho. Outros dois homens informaram que não poderiam ir por motivos diversos. 
O estudo de Maciel e Barbosa (2010) revelou essa tendência de muitos homens a apresentarem dificuldade em comparecer ao acompanhamento psicossocial. A principal justificativa utilizada de não adesão é a necessidade de faltar ao trabalho. Essa dificuldade decorre da polarização entre o público e privado. A esfera pública é tida como mais importante e atribuída ao masculino. A esfera privada é vista como de menor valor e associada ao feminino. Assim, alguns homens não compreendem como algo que aconteceu no espaço privado - a violência - teve consequências na esfera pública - o trabalho (Maciel \& Barbosa, 2010).

A adesão ao método aumentou significativamente após começarmos a utilizar o "Controle de Empréstimo do Livro" (Anexo VI) em 2013 e termos mais experiência para sensibilizar e motivar os homens a aderir ao procedimento. Dos sete homens que faltaram, seis foram dos grupos realizados em 2012. Apenas um faltou em 2013, após o início da utilização desse instrumento de controle dos empréstimos e do aprimoramento do manejo do grupo. Esse instrumento de controle tinha o intuito de diminuir o risco de não devolução do livro, mas parece ter ajudado também no aumento da adesão ao procedimento. Os 13 homens que compareceram ao segundo encontro mostraram boa adesão ao procedimento utilizado neste estudo. Todos afirmaram ter lido o livro e responderam o instrumento.

Além das questões relacionadas ao trabalho e ao uso do controle de empréstimos, imaginamos que outros aspectos podem favorecer a não adesão ao segundo encontro. Esse foi um dos motivos que levou à decisão de adaptar o método de modo a incluir a leitura do resumo do livro durante o processo do grupo na segunda etapa pesquisa. Essa adaptação possibilitou ver os pontos positivos e as dificuldades do método proposto, inclusive se a dificuldade de leitura por alguns participantes poderia ser um determinante na não adesão.

Vamos apresentar a seguir os resultados das duas etapas da pesquisa. Algumas tabelas serão apresentadas separadamente para facilitar a compreensão de suas diferenças. Vamos diferenciar as tabelas da segunda etapa inserindo a letra " $A$ " na frente de sua numeração. Outras tabelas mostrarão o resumo dos resultados das duas etapas em conjunto.

A Tabela 6.2 mostra e enumera os casos em que os homens participaram da proposta metodológica na primeira etapa. A tabela apresenta ainda o número do encontro grupal em que o homem participou do procedimento e a data do encontro. 
Tabela 6.2

Casos Preenchidos pelos Homens na Primeira Etapa

\begin{tabular}{ccc}
\hline Participante & $\mathbf{N}^{\mathbf{0}}$ do Encontro & Data Encontro \\
\hline 1. & 4 & $30 / 4 / 2012$ \\
2. & 4 & $30 / 4 / 2012$ \\
3. & 3 & $7 / 11 / 2012$ \\
4. & 3 & $7 / 11 / 2012$ \\
5. & 2 & $12 / 11 / 2012$ \\
6. & 2 & $12 / 11 / 2012$ \\
\hline 7. & 6 & $19 / 6 / 2013$ \\
8. & 3 & $19 / 6 / 2013$ \\
9. & 4 & $10 / 6 / 2013$ \\
10. & 3 & $10 / 6 / 2013$ \\
11. & 4 & $10 / 6 / 2013$ \\
12. & 5 & $19 / 6 / 2013$ \\
13. & 2 & $19 / 6 / 2013$ \\
\hline
\end{tabular}

Essa tabela revela que 13 homens participaram efetivamente do procedimento na primeira etapa - leram o livro durante a semana, preencheram o questionário e compareceram ao encontro grupal. Os participantes de 1 a 6 participaram em 2012 e os de 7 a 13 em 2013. Os casos 4, 5, 9, 12 e 13 tiveram a participação dos homens e das mulheres em dias e horários diferentes para os membros de cada casal. Nos casos 2 e 9, os participantes não foram encaminhados ao Grupo Misto por violência conjugal. O Participante 2 foi encaminhado por estar na Justiça por supostamente agredir a sua mãe. O Participante 9 estava em litígio com a sua irmã. Nos dois casos, eles também respondiam processo contra a ex-companheira (caso 2) e contra a noiva (caso 9). Assim, eles cumpriram os critérios de inclusão descritos no método e puderam participar do presente estudo. A noiva do Participante 9 estava em acompanhamento no GM. Ela não participou do encontro de discussão do livro, mas respondeu o questionário a pedido do parceiro.

O encontro do GM em que o método foi aplicado variou do $2^{\circ}$ ao $6^{\circ}$. Apesar de o GM prever cinco encontros, o Participante 7 ficou muito interessado na leitura e discussão grupal do livro e pediu para ficar em mais um atendimento. A maioria dos homens participou da dinâmica no $3^{\circ}$ e $4^{\circ}$ encontro do GM, sendo quatro participantes em cada. Três homens participaram no seu $2^{\circ}$ encontro, um no $5^{\circ}$ e outro no $6^{\circ}$ encontro. Nenhum participante foi incluído no primeiro encontro, pois tinha que ter um encontro prévio para explicar o método, aplicar o TCLE, emprestar o livro para leitura durante a semana e entregar o questionário para preenchimento até a próxima reunião grupal.

A Tabela 6.2A resume os casos em que os homens participaram da proposta metodológica na segunda etapa. A tabela apresenta o número do encontro grupal no SERAV/NAFAVD em que o homem participou do procedimento. 
Tabela 6.2A

\begin{tabular}{cccc}
\multicolumn{4}{c}{ Número de Encontro dos } \\
\hline $\mathrm{N}^{\circ}$ do encontro & SERAV & NAFAVD & Total \\
\hline $1^{\circ}$ a $4^{\circ}$ & 8 & 12 & $\mathbf{2 0}$ \\
$5^{\circ}$ a $8^{\circ}$ & 0 & 20 & $\mathbf{2 0}$ \\
$9^{\circ}$ a $12^{\circ}$ & 0 & 5 & $\mathbf{5}$ \\
Total & $\mathbf{8}$ & $\mathbf{3 7}$ & $\mathbf{4 5}$ \\
\hline
\end{tabular}

A Tabela 6.2A acima revela que 45 homens participaram efetivamente do procedimento na segunda etapa - leram o livro, preencheram o questionário e participaram da reflexão sobre o procedimento durante cada grupo. Dentre os 53 homens convidados a participar da pesquisa em seis diferentes grupos no NAFAVD e no SERAV em agosto de 2015, participaram dessa etapa oito homens que estavam em acompanhamento no SERAV e 37 nos NAFAVD de distintas Regiões Administrativas do Distrito Federal.

Consideramos que os homens tiveram boa adesão ao procedimento, já que a grande maioria aceitou participar do estudo e mostrou-se bastante motivada em realizar as tarefas - no tópico sobre os sentimentos despertados nos homens com a leitura do livro vamos descrever algumas de suas reações para ilustrar melhor essa motivação.

Oito homens da segunda etapa da pesquisa não foram incluídos na pesquisa. Desse total, quatro homens tinham dificuldade com leitura/escrita e não quiseram participar do procedimento. Outros quatro participaram do procedimento, mas suas respostas não foram inseridas nos resultados: dois homens participaram do procedimento, mas pediram para não ter seus dados inclusos por temerem a sua identificação e as consequências para seu processo; dois homens também foram excluídos pelo fato de não terem sido encaminhados por violência conjugal, pois um estava na Justiça por processo de maus-tratos contra filha e outro por violência contra irmã.

O procedimento delineado possibilitou verificar se os participantes realmente leram o livro. Permitiu também identificar os homens que não sabiam ou tinham dificuldade em ler o livro e/ou preencher o questionário de modo a oferecer auxílio a eles. Oito participantes $(16,18,23,28,36$, $38,41,49)$ que tinham dificuldade para escrever receberam ajuda para responder o questionário.

O encontro do acompanhamento psicossocial no SERAV e no NAFAVD em que o método foi aplicado variou do $1^{\circ}$ ao $10^{\circ}$. A maioria dos homens que participou da dinâmica - vinte participantes em cada categoria - estava entre o $1^{\circ}$ e o $4^{\circ}$ ou entre o $5^{\circ}$ e o $8^{\circ}$ encontro. Cinco homens estavam entre o $9^{\circ}$ e o $12^{\circ}$ encontro. A estratégia dessa segunda etapa permitiu incluir participantes no primeiro encontro, os Participantes 2 e 3 estavam iniciando o acompanhamento no dia que o procedimento foi aplicado.

As Tabelas 6.2 e 6.2A mostram que, ao todo, 58 homens participaram efetivamente do estudo nas duas etapas - 13 na primeira e 45 na segunda. A amostra na segunda etapa foi ampliada em quase 3,5 vezes em relação à primeira. Essa amostra ampliada possibilitou uma análise mais 
aprofundada das respostas dos participantes, sem perder a característica de ser uma pesquisa qualitativa.

A Tabela 6.3 exibe alguns dados sociodemográficos dos homens de cada etapa. As variáveis descritas são idade, escolaridade, situação ocupacional e renda.

Tabela 6.3

Dados Sociodemográficos dos Participantes em Cada Etapa

\begin{tabular}{|c|c|c|c|c|}
\hline Dados Sociodemográficos & Categorias & $1^{\text {a }}$ Etapa & $2^{\text {a }}$ Etapa & Total \\
\hline \multirow{4}{*}{ Idade } & Até 19 & 0 & 0 & 0 \\
\hline & 20 a 40 & 10 & 30 & 40 \\
\hline & 41 a 60 & 3 & 13 & 16 \\
\hline & Acima de 60 & 0 & 2 & 2 \\
\hline \multirow{4}{*}{ Escolaridade } & NF & 6 & 18 & 24 \\
\hline & NM & 6 & 21 & 27 \\
\hline & NS & 0 & 5 & 5 \\
\hline & PG & 1 & 1 & 2 \\
\hline \multirow{4}{*}{ Situação Ocupacional } & Empregado & 9 & 31 & 40 \\
\hline & Autônomo & 3 & 9 & 12 \\
\hline & Aposentado/Beneficiário INSS & 1 & 2 & 3 \\
\hline & Desempregado & 0 & 2 & 2 \\
\hline \multirow{5}{*}{ Renda } & A & 0 & 2 & 2 \\
\hline & B & 3 & 3 & 6 \\
\hline & $\mathrm{C}$ & 4 & 9 & 13 \\
\hline & $\mathrm{D}$ & 5 & 24 & 29 \\
\hline & $\mathrm{E}$ & 1 & 6 & 7 \\
\hline
\end{tabular}

De acordo com a tabela acima, a maioria dos homens estava com idade entre 20 a 40 anos de idade, sendo 10 na primeira e 30 na segunda etapa, respectivamente. A idade dos 13 participantes da primeira etapa variou entre 23 e 48 anos, com média de 35,69. A idade dos 45 participantes da segunda etapa variou entre 21 e 61 anos, com média de $36,58$.

A maior parte dos homens da primeira etapa tem a escolaridade de Nível Médio - NM e de Nível Fundamental - NF, totalizando seis participantes em cada um desses níveis. Dentre os que têm nível médio, quatro concluíram e dois interromperam o estudo. Quanto aos participantes que têm nível fundamental, cinco não concluíram e um completou esse nível de escolaridade. Um participante tem pós-graduação. Dentre os homens da segunda etapa, a escolaridade variou desde o Nível Fundamental - NF Incompleto a Pós-Graduação - PG completa. A maioria possui Nível Médio completo, totalizando 21 participantes nessa escolaridade. Dentre os que têm nível médio, 16 concluíram e cinco interromperam o mesmo.

As profissões também foram muito variadas nas duas etapas. Incluíram desde as que não exigem escolaridade até algumas que exigiam cursos específicos ou especialização - feirante, porteiro, auxiliar de estofagem, massagista, agente penitenciário, garçom, entregador, cozinheiro, comerciante, técnico-eletrônica, marceneiro, militar das forças armadas, borracheiro, açougueiro, motorista, auxiliar administrativo, auxiliar serviços gerais, despachante, tecnólogo secretariado, 
açougueiro, empacotador, autônomo, ajudante em geral, instrutor autoescola, garçom, pedreiro, conferente, chefe de cozinha, mecânico, policial militar, comerciante, cabeleireiro, porteiro, encarregado, técnico em eletrônica, operador de máquina, gerente, servidor público, carpinteiro, vigilante, bombeiro militar, pintor, vendedor, auxiliar de depósito.

$\mathrm{Na}$ primeira etapa, a maioria dos participantes (nove) estava empregado, três eram autônomos e um estava recebendo o benefício "Seguro Desemprego" por ter perdido o emprego recentemente. A maior parte dos homens (cinco) tinha renda entre um a dois Salários-Mínimos SM naquele período; quatro participantes recebiam entre três e quatro SM; três homens percebiam entre cinco e sete SM e um participante recebia menos de um SM.

$\mathrm{Na}$ segunda etapa, a maioria dos participantes (31) estava empregado, nove eram autônomos, dois aposentados e dois estavam desempregados. A maior parte dos homens (24) declarou que tinha renda entre um a dois SM naquele período, nove participantes recebiam entre dois e quatro SM, seis participantes recebiam menos de um SM, três homens percebiam entre quatro e sete SM e dois mais de sete SM. Um homem não declarou a situação ocupacional e outro não informou a renda.

A Tabela 6.4 apresenta os dados relativos à relação conjugal dos participantes da primeira e da segunda etapa, respectivamente. Ela descreve a situação conjugal, o tempo de relacionamento (em anos) e de separação (em meses) e a quantidade de filhos.

Tabela 6.4

Relação Conjugal e Familiar dos Participantes em Cada Etapa

\begin{tabular}{ccccc}
\hline Dados & Categorias & $1^{\text {a }}$ Etapa & $2^{\text {a }}$ Etapa & Total \\
\hline \multirow{4}{*}{ Situação Conjugal } & Casado & 3 & 4 & 7 \\
& CM & 3 & 15 & 18 \\
& Namorado/Noivo & 1 & 1 & 2 \\
& Extraconjugal & 0 & 1 & 1 \\
& Separado & 6 & 24 & 30 \\
\hline \multirow{2}{*}{ Tempo Relacionamento } & 0 a 5 & 4 & 20 & 24 \\
(anos) & 6 a 10 & 3 & 8 & 11 \\
& 11 a 20 & 3 & 12 & 15 \\
Tempo Separação & $>20$ & 1 & 2 & 3 \\
(meses) & 0 a 12 & 3 & 18 & 21 \\
& 13 a 24 & 1 & 2 & 3 \\
& $>24$ & 2 & 0 & 2 \\
\hline \multirow{2}{*}{ Filhos } & 0 & 2 & 5 & 7 \\
& 1 a 3 & 10 & 36 & 46 \\
& $>3$ & 1 & 4 & 5 \\
\hline Nota. A sigla CM significa "Convive Maritalmente". & & &
\end{tabular}

A maioria dos participantes (sete) da primeira etapa relatou manter algum tipo de relacionamento com suas parceiras, sendo que três conviviam maritalmente, três estavam casados e um estava noivo. Seis participantes estavam separados das ex-companheiras. Quanto aos homens da segunda etapa, a maior parte dos participantes (24) estava separado da ex-companheira e 21 relatou 
manter algum tipo de relacionamento com suas parceiras, sendo que desse total 15 conviviam maritalmente, quatro estavam casados, um namorava e outro tinha relacionamento extraconjugal.

O tempo de relacionamento dos participantes da primeira etapa variou entre 3 a 26 anos, com média de 9,23 anos, em que a maioria dos relacionamentos (quatro) estava com duração de até 5 anos. O tempo de separação variou entre 1 a 36 meses, com média de 16,5 meses - a maioria dos casos (três) estava separado em até 12 meses. A quantidade de filhos variou entre 0 a 6 , em que 10 homens tinham de um até três filhos e três participantes tinham filhos com outras mulheres e/ou com suas parceiras.

O tempo de relacionamento dos participantes da segunda etapa variou entre 1 a 31 anos, com média de 8,98 anos, em que a maioria dos relacionamentos (vinte) estava com duração de até 5 anos - três homens não informaram esse dado. O tempo de separação variou entre 1 a 24 meses, com média de 6,9 meses - a maioria dos casos (18) estava separado em até 12 meses. A quantidade de filhos variou entre 0 a 7 , em que 36 homens tinham de um até três filhos e sete participantes tinham filhos com outras mulheres e/ou com suas parceiras.

A Tabela 6.5 mostra alguns dados sobre o histórico de violência e o processo judicial dos participantes de cada etapa. Ela descreve os casos em que foram implantadas ou não as Medidas Protetivas de Urgência - MPU, o tipo de violência registrada na ocorrência policial, se o homem foi preso em algum momento do processo, se teve reincidência da violência na relação conjugal ou de passagem anterior na Justiça por violência doméstica ou familiar contra mulheres.

Tabela 6.5

Histórico de Violência e de Processo Judicial dos Participantes

\begin{tabular}{ccccc}
\hline Dados & Categorias & $1^{\text {a }}$ Etapa & $2^{\text {a }}$ Etapa & Total \\
\hline \multirow{2}{*}{ MPU } & Não & 7 & 9 & 16 \\
& Sim & 6 & 36 & 42 \\
& Em vigor & 6 & 19 & 25 \\
\hline & VF & 4 & 20 & 24 \\
Violência registrada & A & 6 & 20 & 26 \\
& I & 9 & 25 & 34 \\
& LC & 6 & 13 & 18 \\
& D & 3 & 3 & 6 \\
\hline Preso & Não & 9 & 37 & 46 \\
& Sim & 4 & 8 & 12 \\
\hline Reincidência da & Não & 0 & 7 & 7 \\
violência & Sim & 13 & 38 & 51 \\
\hline Reincidência na & Não & 10 & 38 & 48 \\
Justiça & Sim & 3 & 7 & 10 \\
\hline Nota. A sigla MPU significa "Medidas Protetivas de Urgência". As siglas significam: VF - Vias de Fato, A - Ameaça, I - Injúria, LC - Lesão \\
Corporal, D - Dano. & & &
\end{tabular}

A Justiça determinou Medidas Protetivas de Urgência - MPU a favor das mulheres e/ou em desfavor dos homens em seis casos da primeira etapa (casos 2, 3, 5, 10, 12 e 13) e em 36 da segunda (14-16, 19-23, 25, 26, 28, 30, 31, 33-39, 41,43-54, 56-58). As MPU que ainda estavam em 
vigor quando os homens estavam no acompanhamento psicossocial do SERAV e do NAFAVD foram os mesmos seis da primeira etapa e em 19 casos da segunda $(14-16,19,21-23,26,28,30,31$, 33, 35-37, 48,49, 51, 58). Os Participantes 5, 12 (primeira etapa), 23, 28, 36, 37 (segunda etapa) tinham MPU e estavam convivendo com suas parceiras, mesmo após orientações durante o acompanhamento psicossocial sobre o risco de descumprimento das MPU, inclusive com o consentimento das companheiras.

Quase todos os casos tinham mais de um tipo de violência registrada na delegacia, sendo 11 dos 13 da primeira etapa, em que apenas dois relataram a incidência de uma forma de agressão lesão corporal. Na segunda etapa, 34 casos dos 45 registraram mais de um tipo de agressão, apenas 11 registraram um tipo - quatro registraram somente lesão corporal ou apenas ameaça, três casos tinha exclusivamente vias de fato.

Os Participantes 3, 4, 12 e 13 (primeira etapa), 14, 20, 23, 26, 28, 33, 36 e 52 (segunda etapa) foram presos em algum momento do processo. A grande maioria por descumprir as MPU (casos 3, 12, 23, 26, 28, 33, 36) e os outros em flagrante no dia da ocorrência policial. Todos os casos da primeira etapa tinham histórico de violência relatado pelas mulheres ou pelos próprios homens participantes, mesmo quando não tinha agressões físicas. A agressão denunciada não foi a primeira que aconteceu na dinâmica relacional. Houve um histórico de reincidência da violência em todos os casos reconhecido pelos próprios participantes. Na segunda etapa, apenas sete homens relataram que tinha sido a primeira agressão; a grande maioria relatou a existência de um histórico de violência na conjugalidade.

Três homens da primeira etapa tinham passagem anterior pelo sistema de Justiça por violência doméstica, sendo que dois $(2,9)$ foram denunciados por agressão a outras mulheres - mãe e irmã e um foi com a mesma mulher. Sete homens da segunda etapa também tinham reincidência na Justiça, sendo que os processos anteriores de quatro participantes (15, 30, 33 e 43) eram com a mesma parceira, em três casos $(48,57$ e 58) com outras mulheres: ex-esposa do primeiro casamento, ex-namorada anterior, ex-companheira e por suspeita de abuso sexual contra enteada, respectivamente.

A Tabela 6.6 expõe dados sobre aspectos relacionados à saúde, ao abuso de álcool/drogas dos participantes, histórico de ideação ou tentativa de suicídio e se o caso foi considerado como mais grave. A Tabela descreve também os encaminhamentos propostos pela equipe técnica do GM durante o acompanhamento psicossocial no SERAV na primeira etapa. Essa informação não está disponível para os homens da segunda etapa pelo fato de os participantes não terem concluído o acompanhamento psicossocial no SERAV ou NAFAVD enquanto a pesquisa foi realizada. 
Tabela 6.6

Saúde, Abuso de Substâncias e Encaminhamentos dos Participantes de cada Etapa

\begin{tabular}{ccccc}
\hline Dados & Categorias & $1^{\text {a }}$ Etapa & $2^{\text {a }}$ Etapa & Total \\
\hline Problemas & Não & 10 & 38 & 48 \\
de saúde & Sim & 3 & 7 & 10 \\
\hline Abuso/Dependência de & Não & 5 & 24 & 29 \\
Álcool e/ou outras & Sim & 8 & 21 & 29 \\
Drogas & Reconhece & 8 & 17 & 25 \\
\hline \multirow{2}{*}{ Ideação suicida } & Não & 13 & 36 & 49 \\
& Sim & 0 & 9 & 9 \\
\hline \multirow{2}{*}{ Caso mais grave } & Não & 9 & 36 & 45 \\
& Sim & 4 & 9 & 13 \\
\hline \multirow{2}{*}{ Encaminhamento } & Não & 5 & - & 5 \\
& Sim & 8 & - & 8 \\
\hline
\end{tabular}

De acordo com a tabela, apenas três participantes reconheceram algum problema de saúde na primeira etapa, dois informaram ter diabetes e um ter epilepsia. Na segunda etapa, sete homens citaram ter algum problema de saúde. As principais doenças relatadas foram: pneumonia, hipotireoidismo, epilepsia, hipertensão (três), câncer e alergia.

Oito homens da primeira etapa mencionaram ter algum tipo de problema com o consumo de álcool e/ou outras drogas. Apesar de todos esses oitos participantes terem reconhecido o abuso, cinco deles justificaram a violência exclusivamente pelo abuso dessa/s substância/s. Um homem mencionou, inclusive, o abuso de álcool por parte dele e da parceira como causa exclusiva da violência. Na segunda etapa, 21 homens mencionaram possível abuso dessas substâncias na descrição do histórico de violência, desse total 17 reconheceram o abuso ou o prejuízo desse abuso para a relação. Apesar de a maioria dos participantes das duas etapas abusar ou depender de álcool, nenhum o percebeu como problema de saúde.

A dificuldade de muitos participantes para reconhecerem os agravos à sua saúde revela as marcas da presença dos estereótipos de gênero na socialização dos homens. A própria masculinidade geralmente é entendida por meio do significado de onipotência e da não necessidade de cuidado. Muitos homens apresentam inúmeras justificativas para não buscar ou aceitar ajuda nos programas e ações de cuidado, pois eles entendem a prevenção e o cuidado com a saúde como tarefas essencialmente femininas (Alves et al., 2012; Camargo, Campos, Torres, Stuhler \& Matão, 2011; Lopes \& Leite, 2013; Machin et al., 2011; Nascimento et al., 2009; Separavich \& Canesqui, 2013; Siqueira, 2012).

Nenhum participante da primeira etapa apresentou histórico de ideação ou tentativa de suicídio. Nove homens da segunda $(34,35,37,39,47,49,50,57,58)$ mencionaram esse histórico em algum momento, sendo que a maioria relatou que momentos de crise conjugal, abuso de drogas ou perda de algum familiar foram os desencadeadores da ideação ou da tentativa de suicídio.

Os casos considerados como mais graves foram os 2, 10, 12, 13 (primeira etapa), 14, 15, 23, $28,30,33,35,57,58$ (segunda etapa). A gravidade dos casos foi aferida em contextos em que havia 
alto risco para a integridade física dos cônjuges, especialmente da mulher; situação de escalada da violência; e possibilidade de feminicídio ou homicídio seguido de suicídio (Medeiros, 2015; Soares, 2005; Teixeira, 2009). Incluímos no próximo tópico desses resultados um breve panorama dos casos mais graves para contextualizar a história desses participantes e ajudar na compreensão de suas respostas.

Oito participantes da primeira etapa aceitaram e/ou pediram para serem encaminhados para alguma instituição da Rede Social parceira do SERAV para continuar algum tipo de acompanhamento, terapia ou tratamento além do contexto da Justiça. Os encaminhamentos foram para o Centro de Atenção Psicossocial - Álcool e outras Drogas - CAPS-AD (quatro), para acompanhamento psicossocial no Núcleo de Atendimento das Famílias e Autores de Violência Doméstica - NAFAVD (dois), para o Grupo de Homens do IESB (um) e para Grupo de Casais do Interpsi (um). Cinco participantes negaram a proposta de encaminhamento. Esses homens consideraram que não precisavam, mesmo após tentativa de sensibilização dos/as técnicos/as.

Os dados apresentados pelas Tabelas acima foram importantes para fazer um resumo dos principais aspectos sociodemográficos e das conjugalidades dos participantes. Esses dados corroboram diversos estudos (Diniz, 2011, 2013; Fávero, 2010; Lima \& Büchele, 2011; Medrado \& Méllo, 2008; Macedo, 2013; Matjasko et al., 2012; Medeiros, 2010, 2015; Randle \& Graham, 2011; Silveira et al., 2009; Toneli et al., 2010) que mostram que a violência é um fenômeno universal e afeta homens de todas as idades, raças, crenças religiosas e de diferentes níveis educacional e econômico.

Soares (2012) afirma que o preconceito e o engessamento dos diferentes estilos de conjugalidades contribuem para a compreensão errônea de que homens e mulheres envolvidos em violência conjugal são todos iguais e são pessoas refratárias a mudanças. Esse estudo considera as diversidades dos indivíduos, das masculinidades e a variabilidade das conjugalidades, inclusive das relações marcadas pela violência (Graham-Kevan, 2007; Medeiros, 2015; Oliveira \& Gomes, 2011; Silveira et al., 2009; Teixeira, 2009).

Não podemos deixar de apontar que muitos desafios se impõem para o efetivo entendimento e intervenção nos casos de violência conjugal. Ponderamos ser fundamental essa discussão mais ampla para contextualizar as diversas dimensões da violência ao apresentar os resultados dessa tese de doutorado. Realizamos, assim, um breve panorama de alguns detalhes qualitativos sobre os participantes para contemplar a diversidade de cada caso. Esse panorama pode complementar as informações disponibilizadas nas tabelas acima para uma melhor discussão das respostas dos homens que participaram do procedimento proposto nesse estudo. 


\section{Breve panorama das vivências conjugais dos participantes}

Traçaremos um breve panorama qualitativo de contextualização das vivências conjugais de cada participante da primeira etapa e dos casos mais graves da segunda etapa da pesquisa para ajudar na compreensão das respostas ao questionário. A discussão teórica sobre os aspectos da dinâmica será realizada no próximo tópico, em conjunto com as respostas dos participantes ao questionário. Dessa forma, podemos dar mais um passo para poder contemplar algumas especificidades de lidar com o desafio de ampliar as estratégias metodológicas em relação ao que foi trabalhado na pesquisa do mestrado (Guimarães, 2009).

Apresentaremos alguns dados dos participantes da primeira etapa constantes das anotações dos/as técnicos/as durante a participação dos homens nos cinco encontros do Grupo Misto - GM, principalmente no encontro grupal para reflexão sobre o livro. Esses dados foram obtidos da Ficha de Evolução do GM (Anexo V) e contempla um panorama geral da participação do homem em todo acompanhamento psicossocial, incluindo a sua aceitação ou não de encaminhamentos para outras instituições. Nós demos ênfase apenas em alguns fatos de destaque para favorecer uma contextualização na discussão dos resultados e garantir o sigilo dos participantes.

Incluíremos um breve panorama dos casos mais graves da segunda etapa para contextualizar a história de cada um desses participantes e ajudar na compreensão de suas respostas - tendo o cuidado de manter o sigilo de sua identidade. Apresentamos alguns dados relevantes do questionário sociodemográfico e/ou das anotações dos/as técnicos/as durante a participação dos homens nos grupos do SERAV e do NAFAVD. Para isso, enfatizamos alguns fatos de destaque para favorecer essa contextualização.

\section{Participantes da $1^{a}$ Etapa}

Participante 1: em diversos momentos relatou que ainda era apaixonado pela excompanheira, mas a culpabiliza por tudo. Após a intervenção grupal sobre o livro, conseguiu falar mais de si. Ele percebeu a importância de colocar limites quando tivesse contato com ela, mas sem utilizar a violência, especialmente em questões relacionados a disputas financeiras. Ele compreendeu que teve muitos prejuízos por não conseguir dizer "não" a ela. Ele percebeu também a importância de buscar a Justiça para resolver problemas em decorrência dos cuidados do filho em comum após separação.

Participante 2: ele foi encaminhado ao GM pelo processo em relação à sua mãe, mas também estava vinculado a outro processo de violência contra sua ex-companheira. Ele respondeu ao questionário relacionado à ex-parceira. Ele trouxe um histórico de violência conjugal antiga, grave e recorrente, potencializada por seu abuso de álcool. A relação era considerada de alto risco de reincidência ao iniciar o acompanhamento psicossocial no SERAV. O juiz decretou MPU de 
afastamento do lar, em que ele cumpriu e foi morar com sua mãe. Ele procurou tratamento de alcoolismo por conta própria após a implantação das MPU. Teve adesão assídua no CAPS-AD durante todo GM e boa participação no grupo, principalmente por apresentar muita preocupação com consequências jurídicas para sua vida.

Participante 3: ele foi preso por descumprir as MPU antes de iniciar o GM. A ocorrência foi devido a xingamentos após ele saber que a ex-companheira estava em outra relação. Ele afirmou no primeiro encontro do GM que somente compareceu ao grupo por ser obrigado, mas houve transformação da demanda e ele teve ótima participação no decorrer do acompanhamento psicossocial. Ele ficou angustiado com a história do livro e ansioso para que a personagem encontrasse uma saída. Ele também percebeu a necessidade de afastar da ex-companheira, mas não sabia como. Ele pediu encaminhamento após o término do GM para dar continuidade em seu processo de acompanhamento psicossocial e retomada da vida sem a violência.

Participante 4: teve diversas separações e retornos durante os 26 anos de relacionamento, marcado pelo ciclo da violência. Ele informou ter três filhos/as de 25, 23 e 15 anos de idade. Ele ficou preso por três dias e estavam separados há três meses quando iniciou o acompanhamento. Ele percebeu a necessidade de buscar mudanças para não perder sua família, informou que haviam retomado a relação durante o acompanhamento psicossocial. Ele apresentava abuso de alcool recorrente e foi encaminhado para o CAPS-AD no segundo encontro do GM, mas aderiu ao tratamento apenas antes do último atendimento grupal no SERAV. Ele relatou que reduziu o consumo de álcool, mas tinha esperança de que conseguiria superar a dependência de álcool com a continuidade no acompanhamento no CAPS-AD. Ele informou que pediu ajuda à filha primogênita para responder o questionário e que foi relevante para os dois refletirem juntos sobre a importância da superação da violência para todos/as da família.

A parceira do Participante 4 apresentou discurso extremamente religioso. Inicialmente, ela considerava que não tinha necessidade de estar no GM, que o acompanhamento era importante apenas para o parceiro. No decorrer dos encontros, ela identificou questões transgeracionais e de gênero em sua família de origem que favoreciam a perpetuação da violência em sua relação conjugal. Ela conseguiu refletir sobre sua corresponsabilidade na manutenção da relação e no ciclo de violência, especialmente por dedicar-se exclusivamente à Igreja e por ter "abandonado afetivamente" (sic) a família e o parceiro. Ela não aceitou encaminhamento após o GM, considerou esse grupo como suficiente e que apenas ele precisava dar continuidade em outra instituição, mesmo após tentativa de sensibilização pelos/as técnicos/as da necessidade de prosseguimento de acompanhamento psicossocial. 
Participante 5: informou que o casal possui dois filhos em comum (11 e 13 anos). Ele identificou-se com o personagem do livro: "igual foi a bebida do Brian, mas eu consegui parar e nunca trisquei a mão nela" (sic). Ele não aceitou o encaminhamento proposto pela equipe ao CAPS$\mathrm{AD}$, disse que conseguiu cessar o abuso de álcool sem ajuda de terceiros, acreditava que não iria recair e compreendia que o relacionamento estava bem.

A parceira dele identificou-se totalmente com os personagens do livro, percebeu semelhanças entre as histórias do livro e sua vivência, principalmente em relação ao ciúme e controle do parceiro. Ela referiu melhora na relação por ele ter conseguido cessar o abuso de álcool, mas percebia que a tensão ainda era constante e tinha medo da reinstalação da violência. Ela iniciou o processo de empoderamento pessoal e de desanestesia durante o GM. Ela foi encaminhada para o Projeto Maria da Penha do NPJ/UnB para dar continuidade ao acompanhamento psicossocial e, se fosse preciso, de orientação jurídica.

Participante 6: ele percebeu um histórico de violência na família de origem com a leitura do livro. Ele conseguiu associar o medo que sentia do pai com o medo que a parceira tinha quando ele abusava do consumo de álcool. Ele tem um filho de outro relacionamento e relacionou os conflitos pelo fato de a parceira não aceitar bem a convivência com a criança. A relação é marcada pelo ciclo de violência, com diversas separações e retornos durante o acompanhamento no GM.

Participante 7: possuem uma filha em comum de 6 anos de idade. Ele relatou ter traído a esposa e a culpabilizava pela violência. Ele não considerou a infidelidade como forma de enganá-la e não associou como potencializador de suposto ciúmes excessivo dela. O participante relatou ter presenciado violência conjugal na família de origem. Ele informou que preferia que os pais se separassem quando era criança, mas justificou a manutenção de sua relação conjugal como meio de cuidar da filha. O participante pediu para ficar em mais um encontro para participar da reflexão grupal sobre o livro. Ele disse que se identificou bastante com o Brian, e que essa identificação favoreceu sua aceitação para tratamento no CAPS-AD após o término do acompanhamento no GM.

Participante 8: referiu que houve melhora na relação por ele ter cessado o abuso de álcool. Ele justificou que violência mútua acontecia por ela exigir que ele parasse de beber e ele impor que ela parasse de fumar. As agressões ocorriam por nenhum dos dois ceder. O participante parece não ter lido o livro. Apesar de ele ter dito que leu, algumas de suas respostas ao questionário foram sem nexo.

Participante 9: foi encaminhado ao GM pelo processo com a irmã, mas respondeu o questionário relacionado à noiva, pois também havia processo de violência conjugal. Ela preencheu o questionário à pedido dele. Ele teve ótima participação no GM, inclusive no atendimento para 
reflexão sobre o livro. Ele identificou-se com os dois personagens principais do livro. Eles foram encaminhados para o Grupo de Casais do Interpsi no $4^{\circ}$ encontro do GM.

Participante 10: a dinâmica apresentava grave situação de risco, havia o relato de três tentativas de homicídio contra a ex-companheira. Ele trouxe vários relatos de desqualificação e de culpabilização exclusiva da ex-companheira pela violência, especialmente por um suposto abuso de alcool por parte dela. Ele teve postura extremamente vitimizada, com sentimento de injustiça por ter sido denunciado pela ex-companheira. O participante conseguiu se identificar com os personagens do livro e associar a história de Roz e Brian com a vivência de violência em sua família de origem. Ele percebeu a importância de mudar para o Nordeste para evitar novos conflitos.

Participante 11: apresentou discurso de culpabilização exclusiva e desqualificação da excompanheira durante o GM. Ele foi pouco participativo no grupo, fato que dificultou inserir mais informações sobre o seu acompanhamento.

Participante 12: foi encaminhamento com pedido de urgência para o GM. O caso foi considerado como gravíssimo, inclusive por ter tido agressão física dois dias antes da audiência. Ele foi preso, pagou fiança e foi solto. De acordo com o processo, a violência acontecia desde o início da relação, mas ela pediu para tirar as MPU no dia da audiência. No decorrer do GM, ele trouxe o relato de que os dois abusavam de álcool. Relatou que acompanhamento no grupo, abstinência e igreja foram importantes para cessar a violência.

Ela apresentou discurso semelhante ao dele. Informou que Justiça foi importante limite para ambos pararem de beber e para ter melhoria na relação. Ela trouxe um histórico de violências graves: murro na boca, puxão de cabelo etc. Os filhos presenciavam muitas agressões. Ela informou que gostou muito de participar do GM e se identificou muito com a Roz e o marido com o Brian, especialmente quanto ao abuso de alcool. No entanto, os dois não aceitaram encaminhamentos após o GM como meio de evitar a retomada do ciclo da violência.

Participante 13: caso grave, em que ele deslocou o braço da ex-companheira e colocou fogo na casa após separação. Ele utilizava o filho para aproximar dela após a separação. Ele referiu grande alívio por participar do GM e ter um espaço de escuta e de fala. Ele percebeu o acompanhamento como único local de acolhimento de seu intenso sofrimento diante da separação, mesmo após três anos do término da relação.

Ele percebeu a prisão, o acompanhamento no GM e a participação na estratégia metodológica proposta nesse estudo como extremamente benéficos para ele. Após a prisão, ele informou ter se sentido como um monstro e arrependido, apesar de ainda sentir ódio da ex-parceira. Ele mostrou grande expectativa de que o acompanhamento lhe ajudasse a superar esse sentimento. 
O participante referiu que o livro lhe ajudou para despertar um sentimento de vergonha e raiva de si, especialmente por ter inventado várias mentiras para chamar atenção e provocar ciúmes na ex-companheira. Ele reconheceu-se nos personagens do livro e identificou-se com "as posturas da Roz e do Brian durante o relacionamento" (sic). Ele trouxe que a leitura e a reflexão ajudaram a perceber prejuízos de sua insegurança durante a relação conjugal diante da desigualdade que ele sentia por se considerar como "negro, feio e pobre" (sic).

Ele fez ótimas reflexões durante o GM, iniciou o processo de corresponsabilização pessoal, percebeu que estava com mais controle sobre o sentimento de ódio e que não faria nada contra a exparceira. Ao final do GM, ele pediu para ser encaminhado para o Grupo de Homens do NAFAVD.

Ela percebeu a Justiça como forma de colocar limite nas agressões do ex-parceiro e para se sentir mais segura. Ela identificou-se com a personagem do livro, conseguiu fazer reflexões sobre a importância de adotar outras estratégias para a sua autoproteção. Compreendeu o livro como meio de ampliar sua visão sobre a sua corresponsabilidade na manutenção da relação durante o período que conviveram, especialmente por ter acreditado nas promessas/pedidos de desculpas. Ela estava bem empoderada e decidida quanto à separação durante todo GM.

\section{Participantes da $2^{a}$ Etapa: casos mais graves}

Participante 14: foi preso em flagrante no dia da ocorrência. Eles retomaram a relação após o início do acompanhamento psicossocial, mesmo com MPU em vigor. O laudo do IML apontou a gravidade das lesões em várias partes do corpo. Ela é idosa (71 anos de idade) e ele tem 46 anos. A violência ocorre desde o início da relação.

Participante 15: há histórico de violência com arquivamento de processos anteriores. Houve agressões físicas utilizando instrumentos, como vassoura e pedras. Teve agressões mesmo após o deferimento de MPU e perturbação por ela ter voltado a morar na casa dos pais, eles chamaram a polícia, mas não conseguiram localizá-lo para prendê-lo. O ex-casal possui três filhos pequenos. Ela tem 19 anos. Algumas questões de gênero são relevantes nesse caso. Ele justificou a agressão que gerou a ocorrência por ela ter descumprido sua proibição de não ir amamentar o filho que estava chorando. Ele desferiu um soco no rosto da ex-companheira por ela não querer voltar a residir com ele e houve ameaças caso ela tivesse outra relação conjugal após a separação.

Participante 23: o casal possui um filho de 10 meses. Ela está grávida. Ele já foi usuário de drogas por 6 anos e dependente de álcool por 8 anos, relatou ter conseguido parar o consumo. Ele nega a violência, refere que não agrediu e nem ameaçou a companheira. Ele compreende que ela quem o agrediu e correu atrás dele, ele só fez gestos que a agrediria para se proteger, então ela pegou uma faca e rasgou sua blusa e o perfurou no rosto. Ele também fez ocorrência contra ela. Ele foi expulso de casa e foi morar na rua. Ele descumpriu as MPU de proibição de aproximação e foi 
preso. Retomaram a relação e espera que o Grupo de Homens ajude a melhorar a relacionamento com a parceira.

Participante 28: violência desde o início do relacionamento há 18 anos. Os dois abusam do consumo de álcool. Ele alegou não ter problema de saúde, mas toma medicação para hipertensão e diabetes. Já foi internado por complicação dessas doenças. Ele estava desempregado há um mês. Família vive da renda da parceira. Ela recebe um salário-mínimo como doméstica e Bolsa Família no valor de 260 reais. Eles possuem duas filhas de 14 e 10 anos. A agressão que gerou a ocorrência foi devido ao primo dele supostamente ter tido relação sexual com a filha do casal e ele ter omitido o fato da parceira. Após discutirem, ele a agrediu fisicamente. Houve denúncia da violência conjugal e do suposto abuso sexual. A filha dela, que reside em outra cidade, foi envolvida na violência. Ela desferiu uma facada na testa dele para evitar mais agressões contra a mãe. Ele foi atendido na emergência do hospital. O juiz decretou MPU de afastamento do lar, mas retomaram o relacionamento. Ele foi preso e, após ser solto, retomaram novamente a relação.

Participante 30: durante a audiência, ele mostrou-se resistente ao encaminhamento para o SERAV. Ele está respondendo outro processo por tentativa de homicídio contra terceiros, aguarda o julgamento do tribunal do júri. Há um histórico de traição, de separações e retomada da relação, inclusive várias ameaças de morte contra ela. Em audiência, ela pediu para ele retornar a relação. Ela estava grávida, mas relatou suposto aborto espontâneo devido à violência constante. No Grupo Misto, ele informou que estão separados e ele está em outra relação, mas pretende retomar com a ex-companheira assim que as MPU acabarem. Ele mantém discurso de culpabilização dela, ele tem dificuldade em compreender o ciúme dela e relatou que não precisa fazer mudanças pessoais.

Participante 33: histórico de violência física, psicológica e moral graves com diversas ocorrências policiais nos 20 anos de relacionamento. Todos os processos foram arquivados por pressão dele, inclusive um de lesão corporal comprovado no IML - naquele período, os casos de lesão corporal ainda podiam ser arquivados. Ele fica mais agressivo quando consome álcool. Ele promete mudanças, mas nunca conseguiu cumpri-las. Ele nega violência conjugal e compreende conflito apenas com o filho de 21 anos. Diz que relação é ótima e ela só fez ocorrência sob pressão do filho. As MPU de afastamento do lar e de proibição de aproximação e contato foram decretadas. O caso também foi encaminhado em audiência para o PROVID/PMDF (Projeto Patrulha da Mulher). Ele descumpriu MPU e foi preso. Ela pediu para liberá-lo, juiz encaminhou para SERAV. Eles pretendem retomar a relação após acompanhamento psicossocial no GM e fim das MPU.

Participante 35: ele justifica agressão por supostamente ter flagrado a ex-companheira com outro após a separação. Ele tem um histórico de abuso de álcool. No dia da briga que gerou a ocorrência, ele tentou se matar com uma faca e teve que ser hospitalizado. Ele disse que não tentou 
nada contra ela, apenas contra si. Foi decretado MPU de afastamento do lar e proibição de contato. Ele refere que está cumprindo e está se acostumando com a ideia da separação.

Participante 57: histórico de agressão física potencializado pelo abuso de álcool por parte dele. Ele refere que se conformou com a separação recentemente. Tem os pais como rede de apoio. Ele tem histórico de abuso de álcool há cinco anos, desde os 15 anos de idade. Possui também histórico de ideação suicida e autoflagelo. Ele já foi processado anteriormente por ex-namorada por agressão física, justificava pelo abuso de álcool e ciúmes por parte dele. A ex-namorada retirou o processo a pedido dele.

Participante 58: Histórico de abuso de álcool e drogas, incluindo crack e maconha. Ele refere ter conseguido para de consumir droga há seis anos, continua bebendo aos finais de semana. Ele tentou se matar várias vezes quando usava drogas. Conheceu a ex-parceira em um bar, ela era casada e foi amante dela antes de morarem juntos. Ele tem outros processos: suspeita de abuso sexual da enteada (filha da ex-parceira) e de agressão física contra outra mulher. Ele justifica que não houve abuso, foi acariciar enquanto a enteada dormia e ela assustou. Ele já se envolveu em briga de bar em que levou uma facada no braço. Fez cirurgia e precisa fazer fisioterapia.

A partir desse breve panorama sobre algumas questões qualitativas dos participantes, podemos apresentar os principais resultados das respostas dos homens ao questionário sobre o livro. Essas respostas ilustram bem como a história do livro pode ecoar nas vivências dos homens autores de violência e facilitar a manifestação da negação, minimização e desresponsabilização das agressões e apontar indícios de anestesias relacionais e características duplo-vinculares nas dinâmicas conjugais a partir da perspectivas dos homens autores.

\section{Da história do livro às vivências dos homens autores de violência}

Mostramos a seguir os resultados referentes às respostas dos participantes a cada pergunta dos questionários sobre o livro "Mas ele diz que me ama" (Penfold, 2005/2006). O foco inicial recai sobre as anestesias dos personagens principais - Roz e Brian. Tais anestesias foram se aperfeiçoando no decorrer da história e ficaram cada vez mais fortes à medida que a violência aumentava de intensidade e frequência.

Os paradoxos da relação que apontam para condições duplo-vinculares também foram se consolidando como base da dinâmica conjugal narrada no livro. Roz iniciou com uma leve confusão e com ambiguidade de sentimentos em relação aos primeiros sinais de violência psicológica. Essa violência se instalou por meio de controle e ciúme de Brian e foi progredindo até a ocorrência do primeiro de muitos episódios de agressão física. A violência foi se intensificando até ela chegar, anos depois, à constatação de que estava totalmente fragilizada e despersonalizada. Essa confusão é exemplificada no seguinte relato de Roz: "não sobrou nada de mim" (Penfold, 2005/2006, p. 169). 
Brian ficou cada vez mais controlador e violento. Ele não enxergava os malefícios de seus comportamentos agressivos para a parceira, às crianças e a si mesmo (Guimarães, 2009; Guimarães, Silva \& Maciel, 2007).

Várias anestesias relacionais são apresentadas no decorrer do livro. Elas sustentam a anestesia principal, em torno da qual o livro é nomeado: "mas ele diz que me ama". Os pensamentos, sentimentos e ações anestesiantes favoreceram para que o casal não percebesse a relação como violenta. As anestesias dificultaram também a conscientização das consequências deletérias das agressões para todos os envolvidos. Roz e Brian não viam que não viam a violência. Esse fato configurou um duplo-cego e favoreceu a manutenção da relação por 10 anos (Ravazzola, 1997; Guimarães, 2009; Guimarães et al., 2007).

A relação também foi marcada por padrões de duplo-vínculo. Várias mensagens paradoxais dificultavam a reflexão sobre a relação afetiva e de imenso valor de sobrevivência para os dois personagens. Roz ficou encantada com o estilo de Brian. Ele se apresentou como impulsivo, romântico, sedutor, mas ao mesmo tempo com muito ciúme e necessidade de controle da parceira. Esses atributos contraditórios foram usados para convencer Roz que ele precisava de uma mulher forte para apoiá-lo e ajudá-lo a criar os quatro filhos de seu primeiro casamento (Guimarães, 2009; Guimarães et al., 2007).

As mensagens paradoxais são muito bem retratadas em dois momentos do livro "Mas ele diz que me ama". Quando Brian chegou do trabalho, ele brigou com Roz devido ao alto volume do som que as crianças estavam escutando. No outro dia, Roz e as crianças desligaram o som quando ele chegou. No entanto, ele alegou que precisava ouvir música e brigou com a parceira por conta do silêncio excessivo. Após a discussão, ele reclamou que Roz pensava demais. A personagem fez uma comparação com a história do "Médico e o Monstro", pois nunca sabia qual deles voltaria para casa. Roz relatou a sensação de que ela e as crianças tinham que ficar "pisando em ovos" para evitar as agressões de Brian. Ela começou a perceber que os filhos o amavam, mas ao mesmo tempo começaram a ter muito ódio e temor do pai.

Outra mensagem paradoxal é bem ilustrada quando o casal estava assistindo um programa de TV e Brian elogiou o estilo de cabelo de uma atriz. Ele pediu para a parceira cortar de acordo com aquele modelo. Brian sugeriu que Roz ficaria muito bem com aquele corte, mas ela informou que o seu cabelo sempre foi diferente. Mesmo assim, ela cortou o cabelo para fazer uma surpresa ao parceiro. Quando eles se encontraram, houve uma série de humilhações sobre o corte de cabelo que ele mesmo sugeriu. Roz informou que tentava agradar Brian, mas ele queria controlá-la cada vez mais. Ela informou que não se lembrava mais quem ela era com a exigência de tantas mudanças. 
O ciclo de violência foi se instalando e intensificando de forma sutil. A escalada da violência favoreceu o aumento da frequência dos atos agressivos de Brian e a anulação de Roz. No entanto, eles não percebiam a existência de várias mensagens paradoxais na dinâmica conjugal e não enxergavam a violência na relação. Brian fez a proposição de o casal viver como uma só pessoa; impôs que Roz abrisse mão de seus próprios sonhos; desqualificou os planos profissionais da parceira; denegriu a imagem da mãe de Roz e a isolou do convívio de suas amigas e seus familiares (Guimarães, 2009).

A vivência de diversos ciclos de violência durante os 10 anos de relacionamento favoreceu que Roz começasse a ter dúvidas quanto a seu relacionamento e confusões sobre seus próprios sentimentos. O retorno frequente à fase de Lua de Mel contribuía para que os personagens ignorassem os episódios violentos e resolvessem investir novamente na relação na esperança que as promessas de mudanças fossem cumpridas (Guimarães, 2009; Guimarães et al., 2007).

A violência atingiu todas as formas: ocorreram maus-tratos à Roz, aos filhos e até ao cachorro; estupro contra a parceira; abuso sexual contra a filha; aumento do alcoolismo de Brian; e várias traições com diversas mulheres. O livro revela o desespero e anulação de Roz, seu jogo de racionalizações e as anestesias que a mantinham presa ao parceiro e ao relacionamento (Angelim, 2009; Diniz \& Pondaag, 2004, 2006; Macedo, 2013; Medeiros, 2010; Pondaag, 2009; Ravazzola, 1997, 1998). A história mostra também a dificuldade que todos os envolvidos tinham em reconhecer a violência e nomeá-la, apesar de todos compartilharem a sensação de que havia algo errado no relacionamento (Guimarães, 2009; Guimarães et al., 2007).

A autora é brilhante ao mostrar como a participação da rede social e familiar, principalmente da mãe, de suas amigas e da ajuda profissional por meio de acompanhamento psicossocial foram determinantes para reconhecer e, posteriormente, superar a violência. Todos esses fatores contribuíram para o longo processo de fortalecimento pessoal de Roz na luta contra si mesma e contra a relação, no sentido de quebrar suas anestesias relacionais, o ciclo da violência e os critérios de duplo-vínculo na conjugalidade (Angelim, 2009; Angelim \& Diniz, 2010; Ravazzola, 1997, 2007; Walker, 1999; Watzlawick, Beavin \& Jackson, 2007). O livro confirma a necessidade e a importância das intervenções da rede social e institucional no processo de empoderamento de mulheres para lidarem e/ou saírem dessa situação (Carreira \& Pandjiarjian, 2003; Guimarães et al. 2007).

O livro não retrata a vivência pela perspectiva de Brian, pois foi escrito pela mulher que representou a personagem principal da história. Entendemos que é importante conhecer mais a dinâmica relacional marcada pela violência por meio das perspectivas dos próprios homens autores. 
Após essa breve descrição da história do livro, apresentaremos as respostas dos participantes da pesquisa.

\section{Sentimentos despertados pelos participantes com a leitura do livro}

A primeira pergunta do questionário teve o intuito de averiguar quais foram os sentimentos despertados nos homens autores de violência conjugal com a leitura do livro "Mas ele diz que me ama" (Penfold, 2005/2006). A Tabela 6.7 mostra as categorias de respostas apresentadas pelos participantes da segunda etapa. Os números entre parênteses na primeira coluna na tabela indicam a quantidade de respostas em cada categoria.

\section{Tabela 6.7}

Sentimentos dos Participantes da $2^{a}$ Etapa ao Ler o Livro

\begin{tabular}{|c|c|}
\hline $\begin{array}{c}\text { Sentimentos aversivos gerais e inespecíficos } \\
(28)\end{array}$ & $\begin{array}{l}\text { "Raiva"; } \\
\text { "Sentimento ruim porque foi muito machismo dele"; } \\
\text { "Senti raiva e pena. Do homem senti raiva e nojo. E da mulher eu } \\
\text { senti pena"; } \\
\text { "Mexeu com o sentimento da gente, que não é certo, o problema é } \\
\text { grande"; } \\
\text { "De tristeza"; } \\
\text { "Eu tive um sentimento de raiva pelas mentiras dele, e sentimento } \\
\text { de penar por ela"; } \\
\text { "Tristeza e raiva."; } \\
\text { "Muito triste"; } \\
\text { "Sentimento de tristeza"; } \\
\text { "Senti pena da mulher por não ser tratada do modo correto"; } \\
\text { "De tristeza"; } \\
\text { "Foi ruim porque bebia na frente das crianças."; } \\
\text { "Do som alto eu fiquei triste"; } \\
\text { "Muito triste. Ele só pensava nele mesmo"; } \\
\text { "Amor no começo e do meio pro final raiva e ódio"; } \\
\text { "Muita raiva"; } \\
\text { "Um sentimento ruim de ambas as partes"; } \\
\text { "Tristeza e raiva"; } \\
\text { "Ruim"; } \\
\text { "Revolta"; } \\
\text { "Raiva"; } \\
\text { "De revolta pelo mau caráter"; } \\
\text { "Desprezo, terror..."; } \\
\text { "Revolta"; } \\
\text { "Tristeza"; } \\
\text { "Tristeza"; } \\
\text { "Revoltante e indignação"; } \\
\text { "Marcou para mim, uma vida de terror". }\end{array}$ \\
\hline $\begin{array}{c}\text { Identificação de sentimentos com as suas } \\
\text { vivências (7) }\end{array}$ & $\begin{array}{l}\text { "Que ela ficou muito chateada com ele, igual a minha comigo"; } \\
\text { "Eu tive o sentimento de culpa"; } \\
\text { "Lembrei muito de algo que aconteceu no meu relacionamento"; } \\
\text { "Lembrei das brigas com a minha mulher"; } \\
\text { "O meu sentimento é que parece um pouco com algumas coisas que } \\
\text { já aconteceram com o meu relacionamento, algumas parecem que } \\
\text { eram comigo"; } \\
\text { "O sentimento é que tudo o que ele fez de mal a mulher ele a amava } \\
\text { e isso que aconteceu comigo"; } \\
\text { "Eu gostei da história, eu lembrei da história com minha mulher" }\end{array}$ \\
\hline Sentimentos de negação (9) & $\begin{array}{l}\text { "Raiva. Ódio. Sentimento muito ruim. Acho que ela era boba } \\
\text { demais e ele um porco nojento"; } \\
\text { "Eu achei que o casal tem de dar mais valor ao outro e ser fiel"; } \\
\text { "Sentimento bom porque no início ele estava bonzinho, carinhoso, } \\
\text { depois transformou, comigo era diferente"; } \\
\text { "Que o homem não é 'dono' (proprietário)"; } \\
\text { "Dó da minha mãe"; } \\
\text { "O sentimento que ele tratava a mulher como um lixo e quando } \\
\text { perdeu a mulher ficou louco"; } \\
\text { "Ele queria ser os dois"; } \\
\text { "Nada"; } \\
\text { "Nenhum". }\end{array}$ \\
\hline
\end{tabular}


Nessa pesquisa, a primeira etapa consistiu em um estudo piloto para fornecer subsídios para elaboração do questionário para a segunda etapa. Nesse contexto apresentaremos e discutiremos apenas os resultados da segunda etapa. A leitura do livro teve impacto nos participantes e despertou muitos sentimentos nos homens da segunda etapa. Dos 45 participantes, 37 descreveram sentimentos fortes com a leitura do livro. Diversos sentimentos foram citados: tristeza (por 10 participantes), raiva (nove), sentimento aversivo geral - ruim, mexeu comigo (cinco), pena/dó (quatro), revolta (quatro), ódio (dois), terror (dois), nojo (um), amor (um), culpa (um), desprezo (um), indignação (um). A soma ultrapassa a quantidade de participantes, pois muitos deles citaram mais de um sentimento.

O surgimento desses sentimentos fortes é importante, pois muitas pessoas envolvidas em relacionamentos marcados pela violência podem ficar anestesiadas e deixar de perceber os atos como realmente acontecem. A anestesia pode acontecer com tanto êxito em alguns casos que o malestar deixa de ser sentido (Angelim, 2009; Guimarães, 2009; Guimarães et al., 2007; Levine \& Frederick, 1999; Ravazzola, 1997, 1998).

Dividimos as respostas dos participantes à primeira questão em três categorias: 1) sentimentos aversivos gerais, sem aplicar diretamente ao próprio relacionamento; 2) identificação de sentimentos aversivos relacionados às vivências conjugais; e 3) sentimentos/descrições de fatos que revelaram negação de vivência parecida com os personagens.

A maioria dos participantes apresentou significativo mal-estar diante da vitimização de Roz, das agressões de Brian e das dificuldades do casal em superar a violência. As respostas de alguns homens expuseram sentimentos aversivos gerais, sem aplicar diretamente ao seu relacionamento (primeira categoria) e outros homens identificaram pelo menos algum aspecto de sua vivência conjugal (segunda categoria).

\section{Categoria 1: Sentimentos aversivos gerais e inespecíficos}

Vinte e oito (28) dentre os quarenta e cinco (45) participantes da segunda etapa indicaram um mal-estar geral e inespecífico com a leitura do livro. Os sentimentos descritos foram "Raiva"; "Sentimento ruim porque foi muito machismo dele"; "Senti raiva e pena. Do homem senti raiva e nojo. E da mulher eu senti pena"; "Mexeu com o sentimento da gente, que não é certo, o problema é grande"; "De tristeza"; "Eu tive um sentimento de raiva pelas mentiras dele, e sentimento de penar por ela"; "Tristeza e raiva."; "Muito triste"; "Sentimento de tristeza"; "Senti pena da mulher por não ser tratada do modo correto"; "De tristeza"; "Foi ruim porque bebia na frente das crianças."; "Do som alto eu fiquei triste"; "Muito triste. Ele só pensava nele mesmo"; "Amor no começo e do meio pro final raiva e ódio"; "Muita raiva"; "Um sentimento ruim de ambas as partes"; "Tristeza e raiva"; "Ruim"; "Revolta"; "Raiva"; "De revolta pelo mau caráter"; "Desprezo, terror..."; "Revolta"; 
"Tristeza"; "Tristeza"; "Revoltante e indignação"; "Marcou para mim, uma vida de terror". Algumas narrativas da reflexão ao final do grupo podem exemplificar melhor as respostas desses homens:

“O que a gente vê nessa história é o excesso de possessão do cara” P48

"Mexeu com meus sentimentos todos, tanto pela mulher, e pelo homem também" P18

"Bate uma insegurança, mesmo sabendo que tem coisa boa na história, a gente fica inseguro por ver essa história, triste porque é muita injustiça com ela né” P23

"Dá pena porque é muita injustiça mesmo" P25

"É muito ruim ver o cara mudar de humor todo dia, o cara vem louco em um dia e no outro dia muda tudo, vem todo bonzinho, cheio de amor para dar, como se não tivesse feito nada" P17

Os principais sentimentos gerais citados nas respostas foram os de tristeza e raiva, mas sem mencionar se tinha ou não alguma coisa em comum com o relacionamento. Esses sentimentos gerais podem indicar negação ou minimização da violência (Lila et al., 2012; Silveira et al., 2009) ou um início do processo de reconhecimento da violência na própria relação, mas que não foi mencionado pelos participantes. Todos os participantes da segunda etapa nos quais os seus casos foram considerados como graves, tiveram suas respostas incluídas nessa categoria - o que pode mostrar uma maior tendência a naturalização da violência na própria relação ou que a leitura do livro pode contribuir para o início do processo reflexivo até mesmo de casos mais complexos. Pesquisas futuras podem aprofundar a análise do significado desses sentimentos manifestos por homens autores de violência mais graves.

\section{Categoria 2: Identificação de sentimentos com as suas vivências}

Outros homens conseguiram identificar esses sentimentos aversivos com suas próprias vivências. Essa associação apareceu nas respostas de sete participantes da segunda etapa: “Que ela ficou muito chateada com ele, igual a minha comigo"; "Eu tive o sentimento de culpa"; "Lembrei muito de algo que aconteceu no meu relacionamento"; "Lembrei das brigas com a minha mulher"; "O meu sentimento é que parece um pouco com algumas coisas que já aconteceram com o meu relacionamento, algumas parecem que eram comigo"; "O sentimento é que tudo o que ele fez de mal a mulher ele a amava e isso que aconteceu comigo"; "Eu gostei da história, eu lembrei da história com minha mulher". Algumas narrativas que foram gravadas na reflexão grupal ilustram esses sentimentos:

"Fala do nosso dia-a-dia" P25

"Faz a gente refletir sobre o relacionamento da gente" P32

"Nenhum dos dois [Brian e Roz] saiu lucrando com nada na vida deles. Quando a gente tá aprontando [infidelidade] tudo é bom, mas quando descobre fica ruim, 
porque o relacionamento nunca volta a mesma coisa, por mais que perdoa, a confiança nunca é a mesma. Experiência própria, eu também passei por isso (...) eu mudei mesmo, mas ela tá difícil de acreditar" P34

"O livro é muito interessante. A história em si, a gente chega até a participar do livro com uma certa revolta com o personagem, com o caboclo lá. A gente reflete sobre a gente né" P39

"A gente reflete com algumas coisas e atitudes que a gente não deve tomar" P44

"Pra mim foi ver a traição no livro, é ruim porque a gente fala que ama, que ama e ama, mas quem ama não trai né, daí a gente vê que falha, que tem culpa no cartório" P36

"É triste né. A gente não pode falar de sentimento, se fala, o pessoal já aponta, ele é florzinha, o cara é gay. Eu tava fazendo uma retrospectiva do curso [grupo], a pessoa na história, esse Brian, não expressava o sentimento dele. Às vezes ele tinha o sentimento, assim como todos nós, isso tem a ver com a gente, o homem tem disso né, as vezes ele quer alguma coisa mas ele não expressa realmente o sentimento que poderia facilitar o entendimento da mulher. Tem ciúmes, tem, mas ele demonstra isso na porrada, na cachaça, não fala com a mulher, ai traz a insegurança da mulher. Eu vejo assim, não é igual ao meu caso, o homem quer falar alguma coisa, ele viaja na maionese, aí a mulher não entende" P54

"Eu não falo nada de sentimento, igualzinho ao Brian, tenho que tomar umas [bebida alcoólica] pra falar, criar coragem né. Tem que ir no boteco, só tomar uma ou duas, solta tudo, fala igual uma matraca, parece uma arara" P52

"Milhares de pessoas têm a mesma dificuldade que a gente que tá aqui né. Esse livrinho tá em outros países né, então isso não é só aqui, outros lugares de fora tem esse problema também, mesmo problema, mas a gente tem que tentar né, pra isso tem que abrir mão de algumas coisas, tem que deixar de ser machista” P39

Várias respostas mostraram a tendência de desresponsabilização pelas agressões (Alves \& Diniz, 2005; Lila et al., 2012; Macedo, 2013; Ramos, 2013; Separavich \& Canesqui, 2013), mesmo com a revelação de mal-estar ao descrever seus sentimentos.

\section{Categoria 3: Sentimentos de negação}

A terceira categoria refere-se a citação de sentimentos ou descrições de fatos que revelaram negação de vivência parecida com os personagens. Nove participantes da segunda etapa mostraram essa tendência: "Raiva. Ódio. Sentimento muito ruim. Acho que ela era boba demais e ele um porco nojento"; "Eu achei que o casal tem de dar mais valor ao outro e ser fiel"; "Sentimento bom porque no início ele estava bonzinho, carinhoso, depois transformou, comigo era diferente"; "Que o homem não é 'dono' (proprietário)"; "Dó da minha mãe"; “O sentimento que ele tratava a mulher como um lixo e quando perdeu a mulher ficou louco"; "Ele queria ser os dois"; "Nada"; "Nenhum".

O participante que citou dó da mãe conseguiu identificar a violência na relação conjugal da mãe, mas negou que poderia existir em sua relação com sua parceira. Os dois participantes cujas respostas foram "Nada" e "Nenhum" negaram explicitamente qualquer sentimento ao ler o livro. Essa dissociação total entre a vivência pessoal e a história do livro revela uma tendência de homens 
dessas negarem plenamente a existência de violência em suas relações (Lila et al., 2012; Silveira et al., 2009). Algumas narrativas ilustram esses sentimentos:

"Achei muito interessante, mas muito pouca coisa tinha a ver com o meu caso. Eu tava ouvindo a história e parecia um filme de terror, deu desprezo desse cara, ele era um monstro pra ela. No começo ele prometia que ia levar ela pras estrelas, pra lua, mas depois queria que ela se lascasse" P52

"Esse cara é o retrato do picareta (...). Ele prometia tudo pra ela, depois que conseguiu tudo com ela, ele mostrou quem ele era (...) Eu senti uma revolta, porque a gente vê muito caso desse ai fora" P51

Em resumo, a leitura da história do casal protagonista do livro teve grande repercussão nos participantes. A vivência de mal-estar com a leitura do livro foi relatada por 37 homens da segunda etapa, de acordo com as respostas apresentadas acima. A leitura do livro e a discussão grupal podem favorecer a reflexão de forma indireta sobre a violência nas vivências de homens. A partir de reflexões sobre os sentimentos oriundos do contato com o livro, vários participantes conseguiram associar aspectos da história dos personagens às suas próprias conjugalidades.

A leitura do livro pode facilitar o processo de percepção e reconhecimento da violência no próprio relacionamento conjugal. Para Ravazzola (1997, 1998), essa experiência de vivenciar o mal-estar pode iniciar o processo de desanestesia desses homens e pode ser um dos elementos para levar a algum tipo de reação no sentido de interromper a violência.

Muitos homens transferiram o mal-estar sentido pelo contato com a história dos personagens ao próprio relacionamento conjugal. Em alguns casos, essa percepção do mal-estar foi acompanhada de sentimentos de arrependimentos, remorsos, vergonha e decepção com as próprias atitudes. O método utilizado nesse estudo favoreceu a emergência desses sentimentos fortes e aversivos. O contato com esses sentimentos pode ajudar no início do processo de quebra de suas próprias anestesias relacionais e da tendência de alguns homens em repremir os seus sentimentos (Ravazzola, 1997, 1998, 2015).

Vários estudos (Camargo et al., 2011; Fávero, 2010; Medrado \& Méllo, 2008; Moore, 2015; Nascimento et al., 2009; Norman, 2011; Randle \& Graham, 2011) enfatizam que muitos homens têm dificuldade para expressar sentimentos. O processo de socialização masculina estimula a repressão de suas emoções. Essa repressão tem impacto direto sobre a saúde, a morbimortalidade e a violência dos homens e de toda sociedade. A pressão social exerce, inclusive, intensa influência na saúde mental de homens. A sociedade impõe vários dilemas para a população masculina: influencia os homens a reproduzirem alguns privilégios das masculinidades e, simultaneamente, os estimulam a se oprimirem e a se distanciarem de seus sentimentos. A agressividade é um dos poucos sentimentos estimulados e aceitos socialmente para os homens expressarem, o que aumenta a vulnerabilidade da população masculina para a adoção de condutas destrutivas e autodestrutivas. 
Dessa forma, essa estratégia apresentou potencialidade para ajudar alguns homens a reconhecerem e expressarem os seus próprios sentimentos.

As respostas à primeira pergunta do questionário expuseram diversos sentimentos intensos dos homens em relação à experiência de ter contato com a história dos personagens. Os sentimentos provenientes da comparação entre a própria história vivenciada e a dos personagens revelaram que o livro "Mas ele diz que me ama" foi um instrumento com grande potencial para acessar os sentimentos e facilitar a reflexão de homens sobre a violência conjugal. Essa estratégia metodológica revelou seu potencial de intervenção com homens autores de violência.

\section{Naturalização da violência na comparação entre as vivências do livro e as dos homens}

A segunda e a terceira perguntas do questionário tiveram o objetivo de compreender os elementos que os homens autores de violência consideraram semelhantes e diferentes em relação à vivência dos personagens do livro. A Tabela 6.8 apresenta esses elementos identificados pelos participantes como respostas a essas duas questões.

Tabela 6.8

Comparação entre a História dos Participantes da $2^{a}$ Etapa e a dos Personagens

\begin{tabular}{|c|c|c|}
\hline Categorias & Comuns & Diferentes \\
\hline $\begin{array}{c}\text { Desresponsabilização } \\
(14 ; 6)\end{array}$ & $\begin{array}{l}\text { "Bebida. Os filhos também viam, um filho só, tenho 3"; } \\
\text { "Bebida, eu tava de ressaca, ela me perturbou e taquei um } \\
\text { tênis nela."; "O que parece com minha história é o ciúme } \\
\text { possessivo e a desconfiança entre o casal."; "O que tem de } \\
\text { parecido é que eu sofro calado e a Justiça me leva como o } \\
\text { culpado"; "Ciúme"; "Muito ciúmes da parte dela"; "Bebida, } \\
\text { xingamentos"; "Outra mulher no relacionamento"; "A minha } \\
\text { história tinha bebida"; "Ciúme"; "Bebida"; "Fui mal amado } \\
\text { também"; "Bebida. Eu ficava agressivo quando eu bebia"; } \\
\text { "Ciúmes e discussão de ambos" }\end{array}$ & $\begin{array}{l}\text { "A minha história eu já tinha separado e arrumei } \\
\text { outra namorada. Ela mentia, não aceitou e brigou } \\
\text { com minha atual e eu separei a briga e ela me } \\
\text { denunciou."; "A gente está junto por causa do } \\
\text { filho."; "É que eu trabalhava e trabalhava e hoje } \\
\text { luto para retornar a trabalhar. Não por causa da } \\
\text { minha mulher, mas sim por causa da situação que } \\
\text { ela me colocou."; "O intrometimento dos } \\
\text { familiares dela, ou seja, pai e mãe e colegas"; "Eu } \\
\text { tive diálogo. Na minha teve fingimento"; "A } \\
\text { violência cometida teve a intenção de conter". }\end{array}$ \\
\hline $\begin{array}{c}\text { Minimização } \\
(14 ; 20)\end{array}$ & $\begin{array}{l}\text { "As promessas de mudar"; "Bebida. Os filhos também viam, } \\
\text { um filho só, tenho 3."; "Ligações de madrugada"; "As } \\
\text { crianças"; "Tem a separação"; "Bebida, xingamentos"; "As } \\
\text { discussões e a insensibilidade, ou seja, a falta de } \\
\text { companheirismo"; "A raiva que eu passei, o amor que sinto } \\
\text { pela minha família, reclamava que acordava cedo e a mulher } \\
\text { não fazia café"; "Na parte que ele diz não desista de nós logo } \\
\text { agora, não depois de tudo que passamos"; "Nas ligações } \\
\text { quando nós brigamos."; "Só os telefonemas"; "Discussão e as } \\
\text { palavras pesadas"; "Ciúmes e discussão de ambos"; } \\
\text { "Relacionamento de ciúmes, brigas e separação". }\end{array}$ & $\begin{array}{l}\text { "Filhos envolvidos na história e a inexistência de } \\
\text { traição."; "Acho que a traição"; "A traição, pois no } \\
\text { meu caso não traí minha companheira."; "Não teve } \\
\text { agressão verbal, não teve xingamento por conta } \\
\text { dos odores."; "Falsidade"; "Não tínhamos filhos"; } \\
\text { "Não tive outra mulher"; "Mentiras"; "Não tinha } \\
\text { traição"; "Na minha história não teve traição"; "A } \\
\text { história deles é mais complicada que a minha"; "A } \\
\text { ignorância que ele tem com a sua parceira"; } \\
\text { "Muitas coisas"; "Não sou tão egoísta, ele passou } \\
\text { dos limites"; "Muita diferença entre ele à traição } \\
\text { da dita cuja"; "Eu não traía minha mulher."; "Não } \\
\text { teve agressão, humilhação"; "Eu nunca desfiz da } \\
\text { minha esposa"; "Frieza e cara de pau do homem"; } \\
\text { "A humilhação e constrangimento"; "Traição". }\end{array}$ \\
\hline $\begin{array}{c}\text { Negação } \\
(16,11)\end{array}$ & $\begin{array}{l}\text { "Nada a ver, pois minha história foi totalmente diferente } \\
\text { disso!"; "Nada, só a separação."; "Nada"; "Nada"; "Não tem } \\
\text { nada a ver com a minha história"; "Nada"; "O amor que ele } \\
\text { sente"; "De vez em quando ele era bom, de vez em quando } \\
\text { ele se transformava, eu não mudo com minha esposa, eu sou } \\
\text { bom para ela"; "Lembrei da minha mãe sofrendo"; "Nada"; } \\
\text { "O amor e companheirismo por parte da esposa"; "Nada"; } \\
\text { "Nada"; "Nenhuma"; "Nada parecido". }\end{array}$ & $\begin{array}{l}\text { :"Tudo."; "Tudo"; "Ele tem } 2 \text { personalidades, eu } \\
\text { nunca desvalorizei minha esposa"; "Nós nos } \\
\text { amamos sempre e ainda nos amamos"; "Tudo"; } \\
\text { "Eu nunca agredi minha esposa, meu sobrinho que } \\
\text { levou ela na delegacia, ela quis tirar depois"; "Não } \\
\text { tem nada a ver com a minha"; "Tudo"; "Tudo é } \\
\text { diferente"; "Em meu relacionamento sempre } \\
\text { existiu diálogo, compreensão e respeito"; "Tudo". }\end{array}$ \\
\hline $\begin{array}{l}\text { Início do processo de reconhecimento } \\
(4,7)\end{array}$ & $\begin{array}{l}\text { "A história é muito parecida com a minha."; "As outras } \\
\text { relações na consciência e a ignorância minha e dela"; "Meu } \\
\text { lado meio machista kkk"; "Violência". }\end{array}$ & $\begin{array}{l}\text { "Muito pouco."; "Nada"; "Era o contrário, eu a } \\
\text { amava demais e ela nunca quis, mas eu não } \\
\text { conseguia enxergar."; "A minha história é igual a } \\
\text { essa"; "Minha história é igual"; "Quase nada, } \\
\text { muito parecido"; "Não tinha diálogo nenhum". }\end{array}$ \\
\hline
\end{tabular}

A primeira coluna indica as categorias criadas, a segunda e a terceira colunas mostram, respectivamente, as respostas descritas como parecidas e diferentes pelos homens. Os números entre 
parênteses na primeira coluna da tabela indicam a quantidade de respostas em cada categoria, sendo que o primeiro mostra a quantidade de respostas comuns e o segundo representa a quantidade de diferentes.

Os homens descreveram em suas respostas ao questionário diversos elementos comuns e diferentes entre a suas histórias e a dos personagens do livro. As respostas dessas comparações apresentadas pelos participantes são discutidas a seguir.

\section{Elementos semelhantes entre a história dos homens e a do livro}

Os aspectos que os homens identificaram como semelhantes foram relacionados às respostas dispostas em quatro categorias: desresponsabilização; minimização, negação da violência e início do processo de reconhecimento da violência. A tabela acima mostra que, na segunda etapa, 14 participantes se desresponsabilizaram, 14 minimizaram, 16 negaram a violência ao apontarem elementos semelhantes entres as vivências pessoais e a do livro. Apenas quatro homens trouxeram elementos que demonstravam algum reconhecimento de sua corresponsabilidade na relação marcada pela violência.

A soma de elementos em cada categoria ultrapassa a quantidade de participantes, pois muitos deles citaram mais de um elemento de sua vivência como semelhante à história do livro. Muitos elementos citados pelo mesmo participante perpassaram mais de uma categoria. De acordo com Silveira et al. (2009), as categorias não podem ser estanques e nem excludentes, elas podem e devem apresentar diversas tensões e correlações em vários momentos. Essas categorias são detalhadas abaixo.

Em relação à primeira categoria, na segunda etapa, 14 homens identificaram como semelhante com a história do livro algum aspecto de desresponsabilização da violência. Além do álcool e da culpabilização da parceira, eles citaram o ciúme, desconfiança, presença de amantes, ser mal amado. Esses elementos que externalizam a responsabilização em relação aos homens são mencionados nas seguintes respostas: "Bebida. Os filhos também viam, um filho só, tenho 3"; "Bebida, eu tava de ressaca, ela me perturbou e taquei um tênis nela."; "O que parece com minha história é o ciúme possessivo e a desconfiança entre o casal."; “O que tem de parecido é que eu sofro calado e a Justiça me leva como o culpado"; "Ciúme"; "Muito ciúmes da parte dela"; "Bebida, xingamentos"; "Outra mulher no relacionamento"; "A minha história tinha bebida"; "Ciúme"; "Bebida"; "Fui mal amado também"; "Bebida. Eu ficava agressivo quando eu bebia"; “Ciúmes e discussão de ambos". Algumas falas dos participantes durante a reflexão grupal ilustram bem essa desresponsabilização da violência:

"Eu me identifiquei com o ciúme do cara. Eu sou ciumento e a mulher é ciumenta, e nesse caso gera conflito mesmo. No caso do livro, ela não demonstrou ciúmes, mas 
demonstrou insegurança. A insegurança de ambas as partes gera conflito, não tem jeito, é inevitável" P43

"Fiquei 10 dias preso, fiquei desorientado, eu perdi a noção do que estava fazendo, só queria ver o meu filho. Mas ela me ligava, ela via que a situação [financeira] tava ruim e eu voltei pra ela. Mas eu já sabia com quem eu tava. Eu trabalhava e tudo que eu ganhava era pra dentro de casa, mas ela não dava valor" P23

"Ela nunca fez nada pra mim, a não ser essa criança que foi uma benção. Por causa dessa criança eu larguei muita coisa, até as drogas. E ela me deu as facadas também" $\mathrm{P} 23$

"Hoje em dia, quando ela vem pra cima de mim, eu só corro e corro. Eu já cansei, se não fosse a criança eu já tinha saído de casa" P23

O abuso de álcool foi o principal elemento citado pelos homens para se desresponsabilizar da violência. Essa identificação com o consumo de álcool do personagem do livro pode ter dois significados: um benéfico, que é relacionado ao reconhecimento das consequências do abuso; e outro negativo, pois pode servir como uma externalização da responsabilidade pela violência (Aguiar, 2009; Guimarães, 2009; Grossi, 1999; Mahmoud, 2003; Manita, 2008; Schmidt, 2010).

O primeiro sentido desse reconhecimento pode ser favorável, pois é difícil para muitos homens compreenderem as consequências negativas do abuso de álcool (Acselrad, Karam, David \& Alarcon, 2012; Araújo, 2012; Machin et al., 2011; Separavich \& Canesqui, 2013). Esse reconhecimento pode ter colaborado para a compreensão dos homens da necessidade de reduzir ou interromper o consumo de álcool, inclusive de buscar ajuda ou tratamento.

Alguns estudos (Camargo et al., 2011; Nascimento et al., 2009; Schmidt, 2010) mostram que o fato de os homens interromperem o abuso de álcool é importante, mas não é suficiente para superar a violência em muitos casos. Essa interrupção pode ser incipiente e fazer parte do ciclo de violência. Há alta probabilidade de recaída do abuso e/ou da violência, principalmente quando a pessoa não está inserida em acompanhamento ou tratamento profissional.

O segundo significado da identificação com o consumo de álcool do personagem do livro pode ser maléfico. Muitos homens justificam a violência pelo abuso ou dependência de álcool. $\mathrm{O}$ consumo de álcool é utilizado como desculpas pelos homens, pode ser uma forma de autodesculpabilização, racionalização ou neutralização da violência (Aguiar, 2009; Manita, 2008; Schmidt, 2010). O álcool pode servir como um meio de desresponsabilizar o homem e atribuir a violência a fatores externos (Dohmen, 2006, 2006a; Grossi, 1995; Nascimento et al., 2009). A socialização masculina favorece a negação e a minimização da violência e do abuso de álcool (Oliveira \& Gomes, 2011; Separavich \& Canesqui, 2013).

Mahmoud (2003) alerta que essas justificativas da violência têm uma dimensão consciente/visível, em que o consumo de álcool atua como desinibidor, favorece o aumento da violência e mostra virilidade dos homens. A dimensão inconsciente/invisível atua como justificativa para ficar na relação. A necessidade de ser cuidado pela parceira reforça a manutenção da relação e 
da violência conjugal. Manita (2008) afirma que a violência é um comportamento deliberado, intencional e uma busca para controlar o outro. Não pode ser entendida como fruto de determinação biológica ou psicopatológica, mesmo em casos de coocorrência de alcoolismo.

A minimização da violência foi a segunda categoria criada de acordo com os aspectos semelhantes à história do livro descritos pelos participantes. Os homens perceberam a violência apenas como meros conflitos na relação, banalizando o seu impacto. Esses conflitos foram evidenciados nas seguintes respostas de 14 participantes, que minimizaram a violência ao comparar os elementos semelhantes entre suas vivências e a do livro: "As promessas de mudar"; "Bebida. Os filhos também viam, um filho só, tenho 3."; "Ligações de madrugada"; "As crianças"; “Tem a separação"; "Bebida, xingamentos"; "As discussões e a insensibilidade, ou seja, a falta de companheirismo"; "A raiva que eu passei, o amor que sinto pela minha família, reclamava que acordava cedo e a mulher não fazia café"; "Na parte que ele diz não desista de nós logo agora, não depois de tudo que passamos"; "Nas ligações quando nós brigamos."; "Só os telefonemas"; "Discussão e as palavras pesadas"; "Ciúmes e discussão de ambos"; "Relacionamento de ciúmes, brigas e separação".

Os participantes relataram termos como "brigas", "erros", "incompreensões", "poder", "mentiras", "xingamentos", “discussões”, "palavras pesadas”, mas eles não mencionaram a palavra "violência" ou "agressão". Alguns participantes perceberam os prejuízos para os filhos, mas não para os membros do casal. Outros trouxeram a ambiguidade de sentimentos existente na relação. Essa situação pode indicar uma dificuldade em nomear a violência conjugal e uma tendência a minimizá-la (Angelim, 2009; Diniz \& Pondaag, 2004, 2006; Guimarães, 2009; Pondaag, 2003, 2009; Silveira et al., 2009; Toneli et al., 2010). As narrativas dos participantes abaixo exemplificam essa minimização da violência:

"No meu caso não teve agressão, foi mais falta de diálogo, quando a gente separou nenhum dos dois dava sossego, nem ela dava pra mim e nem eu dava pra ela, mas quando veio as discussões quem tomou mais fui eu. Ela pediu as medidas protetivas, pediu 100 metros de afastamento (...) mas quando ela precisava, ela me ligava” P26 "O que era parecido era a ignorância" P29

"Só a ignorância e a falta de confiança" P31

"Quando eu vi que ela começou a colocar cara diferente dentro de casa, em dois meses ela ficou com dois caras diferentes, eu preocupei com as crianças... Eu cheguei a falar coisas horríveis para ela mesmo, num vou negar. Foi coisa de hora, daí ela me denunciou. Fiquei 22 dias presos... Depois disso não tenho mais contato com ela, só para ver a questão dos meninos, e só” P26

Essa minimização pode ser percebida também na constatação de indícios da existência de um ciclo de violência em muitas relações. Os participantes tiveram a tendência de enfatizar as fases de lua de mel e banalizar as fases de aumento de tensão e tensão máxima. Esses indícios foram identificados nas respostas de cinco participantes da segunda etapa. Esses homens mencionaram 
alguns elementos do ciclo da violência: "As promessas de mudar"; "Tem a separação"; "A raiva que eu passei, o amor que sinto pela minha família, reclamava que acordava cedo e a mulher não fazia café"; "Na parte que ele diz não desista de nós logo agora, não depois de tudo que passamos"; "Relacionamento de ciúmes, brigas e separação". A instalação do ciclo da violência pode dificultar a reflexão sobre a situação da relação com violência (Angelim, 2009; Walker, 1979, 1999; Walker, Duros \& Tome, 2007).

A repetição do ciclo contribui para que mulheres e homens se adaptem aos altos e baixos da vivência conjugal. A fase de Lua de Mel do ciclo da violência é a que mais favorece a perpetuação do relacionamento (Angelim, 2009; Cantera, 2007; Walker, 1979; Walker et al., 2007). É muito comum as pessoas entrarem em exaustão com a escalada do ciclo, ingressando em um verdadeiro padrão de desamparo aprendido (Guimarães, 2009; Walker, 1999). Essa exaustão pode ser identificada no relato do Participante 9: "sem saber o que fazer".

O abuso de álcool e o ciclo da violência discutidos nas duas categorias acima podem ter estreita relação. Schmidt (2010) afirma que o uso, abuso ou dependência de alcool apresenta uma função paradoxal no ciclo da violência. Os homens podem compreender o consumo de álcool como fornecedor de alívio para lidar com as tensões do relacionamento. Ao mesmo tempo, esse consumo contribui significativamente para o aumento ou explosão das tensões, facilitando a re/instalação das agressões. O pesquisador defende que o acompanhamento psicossocial pode ser fundamental para alguns homens refletirem sobre esse papel paradoxal da violência e do álcool.

A terceira categoria estabelecida foi a de negação da violência. Dezesseis participantes da segunda etapa também negaram a violência em suas relações ao compará-las com a história do livro: "Nada a ver, pois minha história foi totalmente diferente disso!"; "Nada, só a separação.”; "Nada"; "Nada"; "Não tem nada a ver com a minha história"; "Nada"; "O amor que ele sente"; "De vez em quando ele era bom, de vez em quando ele se transformava, eu não mudo com minha esposa, eu sou bom para ela"; "Lembrei da minha mãe sofrendo"; "Nada"; "O amor e companheirismo por parte da esposa"; "Nada"; "Nada"; "Nenhuma"; "Nada parecido". Os participantes ressaltaram que não havia nada em comum ou nenhuma forma de violência parecida com a do livro ou apenas a existência de coisas boas em suas relações: amor ou ser bom para a parceira. Um homem só identificou a violência na relação de seus pais, mas não percebia na sua. Esse processo de negação será discutido melhor no próximo tópico - sobre os elementos que os homens encontraram como diferentes entre suas vivências e a dos personagens. As narrativas dos participantes reforçam como os homens expressam essa negação da violência:

"Esse cara aí do livro era o diabo. Comigo foi totalmente diferente, não teve agressão, mas aconteceu parecido com o meu pai. Ele tinha 62 anos e sempre aprontou com minha mãe, bateu muito nela, abandonou os quatro filhos pequenos em casa, tinha muita 
mulher fora, mas quando ficou prostrado na cama, adivinha quem cuidou dele? (...) Minha mãe fez igual a mulher do livro, quando o cara do livro perdeu o emprego foi ela que cuidou dele também" P26

"Eu percebi no livro que ele pediu uma chance pra ela. Ela deu chance pra ele e ele jogou a chance fora. Foi o que eu captei, não tem nada a ver com minha história mas a gente tem que ficar esperto. Eu acho assim, se o cara pede uma chance, ele tem que pegar e segurar. Agora se ele pede e ela dá, mas ele vacila, ele tem que se lascar mesmo. Porque ai fica complicado né, o cara abusa" P44

O reconhecimento da violência é um dos primeiros dos diversos passos necessários para a sua superação. Alguns participantes conseguiram descrever respostas que indicaram alguma reflexão sobre a sua responsabilização das agressões. Na segunda etapa, quatro participantes mencionaram algum elemento de corresponsabilização: "A história é muito parecida com a minha."; "As outras relações na consciência e a ignorância minha e dela"; "Meu lado meio machista kkk"; "Violência". Os elementos citados pelos homens que podem indicar esse reconhecimento foram a infidelidade, ignorância e machismo. Um participante citou diretamente a palavra "violência". As narrativas dos participantes exemplificam esse início do processo de reconhecimento da violência:
"A minha história é igualzinho a essa, não tem nada de diferente" P29
"O tratamento que os psicólogos têm aqui no grupo é totalmente diferente do policial e do juiz, pra eles nós somos bandidos, aqui é o único lugar que ouve a gente. Aqui somos todos iguais, posso falar, quero ver os meus erros pra mudar" P26
"Minha história foi quase igual, com ciúmes de ambas as partes, bebida, aquele futebol, depois do futebol ia pra outro lugar e a mulher por ser evangélica não aceita chegar em casa com bafo de cachaça, cheio de goró. E por ai foi, ela tem grupo de amigos do trabalho e da igreja, eu podava esses amigos. Só que ai a gente mudou bastante, ela me deu uma oportunidade e eu aproveitei, num fiz igual ao livro não. Com isso eu mudei muito mesmo entendeu. Eu converso com ela, continuo indo pro meu futebol, bebo minha cervejinha, mas não igual antigamente. Eu agora procuro ir nos lugares que ela frequenta, antigamente eu não ia. Eu queria que ela fosse onde eu fosse, mas eu não ia onde ela chamava, nem amarrado" P39

Essa comparação pode ser o início do reconhecimento da violência por meio da verificação inicial das agressões na relação dos personagens do livro para uma posterior constatação na própria conjugalidade (Araújo, 2012; Macedo, 2013; Medrado, 2009; Medrado et al., 2011; Randle \& Graham, 2011; Separavich \& Canesqui, 2013).

As anestesias evidenciadas nas respostas dos homens revelaram um continuum de naturalização ao comparar as semelhanças entre as suas vivências conjugais com a história do casal protagonista do livro. Ravazzola $(1997,1998)$ afirma que as pessoas em situação de violência apresentam verdadeiras dissociações produzidas pelas anestesias. Há uma dissociação entre os seus sentimentos, ações e comportamentos. Essa dissociação não é intrínseca ao indivíduo, a socialização de gênero influencia diretamente na forma com que homens enxergam a violência 
conjugal. Os homens podem passar a negar a situação, a minimizá-la e justificar seus atos por meio de racionalizações e não refletir sobre suas crenças sociais.

Alguns homens não conseguiram perceber aspectos da violência em suas relações, negaram totalmente as agressões - totalizando 16 participantes. Outros homens conseguiram perceber algum aspecto da violência, mas tiveram a tendência de minimizá-la (14 homens) - perceberam, mas a banalizaram. Outros se desresponsabilizaram (14 homens), compreenderam que o relacionamento não estava bem ou até mesmo que tinha violência, mas externalizaram a responsabilidade para a parceira ou para outros eventos. Ou seja, alguns negaram totalmente, outros perceberam e minimizaram o seu impacto, outros compreenderam sua existência, mas não perceberam como sua responsabilidade.

O livro pode ter ajudado na manifestação de mecanismos de naturalização da violência por meio da identificação inicial com os personagens do livro ou mesmo quando não houve identificação alguma, como no caso da negação. Mesmo que os participantes não percebam toda a dimensão da violência em suas relações conjugais, a manifestação de alguns aspectos de sua naturalização tais como o abuso de álcool, o ciclo da violência e as brigas e erros na dinâmica conjugal pode contribuir para que os participantes possam trabalhar a ressignificação desses elementos na continuidade do acompanhamento psicossocial.

A continuidade desse acompanhamento pode ajudar a iniciar o processo de reflexão sobre os diversos problemas psicossociais e de saúde que afetam as mulheres vítimas e os homens autores devido às agressões (Alvarenga, 2012; Araujo, 2012; Couto \& Schraiber, 2005; Medeiros, 2010; Oliveira, 2015; Oliveira \& Gomes, 2011; Randle \& Graham, 2011). Após a discussão sobre os elementos semelhantes, apresentamos e discutimos os aspectos diferentes descritos pelos homens ao comparar as histórias pessoais e a do livro.

\section{Elementos diferentes entre a história dos homens e a do livro}

As respostas dos participantes sobre as diferenças de suas histórias com a dos personagens do livro baseou-se em comparações sobre o que foi melhor ou pior em cada vivência. A grande maioria dos homens trouxe respostas que apontaram as próprias vivências como menos graves que a história do livro, se desresponsabilizaram pelas agressões ou negaram a violência. Ao todo, 38 homens apresentaram comparações nesse sentido na segunda etapa.

A maioria desses participantes relacionou a ocorrência de agressões mais brandas ou a não existência de traições, mentiras e enganações, revelando a tendência de minimização da violência sendo 20 na segunda etapa. Outros 11 homens negaram totalmente qualquer semelhança. Seis homens apresentaram uma tendência a se desresponsabilizar. Por último, sete participantes conseguiram descrever respostas que indicaram alguma reflexão sobre a sua responsabilização das 
agressões ao relatar a diferença entre suas histórias pessoais e a do livro. Descreveremos a seguir cada uma dessas categorias criadas a partir dessa comparação dos participantes.

As respostas que podem indicar uma minimização da violência foi a mais recorrente dos homens da segunda etapa. A maioria dos participantes consideraram suas vivências como menos graves que a história do livro por considerarem suas agressões como mais brandas, qualitativamente diferentes ou a inexistência de traições e mentiras na relação.

$\mathrm{Na}$ segunda etapa, 20 homens apresentaram respostas que revelam essa minimização da violência: "Filhos envolvidos na história e a inexistência de traição."; "Acho que a traição"; "A traição, pois no meu caso não traí minha companheira."; "Não teve agressão verbal, não teve xingamento por conta dos odores."; "Falsidade"; "Não tínhamos filhos"; "Não tive outra mulher"; "Mentiras"; "Não tinha traição"; "Na minha história não teve traição"; "A história deles é mais complicada que a minha"; "A ignorância que ele tem com a sua parceira"; "Muitas coisas"; "Não sou tão egoísta, ele passou dos limites"; "Muita diferença entre ele à traição da dita cuja"; "Eu não traía minha mulher."; "Não teve agressão, humilhação"; "Eu nunca desfiz da minha esposa"; "Frieza e cara de pau do homem"; "A humilhação e constrangimento"; “Traição". As narrativas dos participantes que foram gravadas durante a reflexão ao final dos grupos exemplificam essa possível minimização da violência:

"No meu caso eu nunca desvalorizei minha esposa, ele [Brian] sempre desvalorizava" P32

“A história dele é mais grave, é mais complicada porque o agir dele, ele acha que pode tudo, que pode desvalorizar a mulher, chamou ela de imunda, botou o filho pra beber" P30

"Tinha pouca coisa a ver com o meu caso. A parte que tinha eu coloquei aqui, era discussão, bate boca, mas eu achei que ele era sínico e duas caras. Eu não traia, eu era verdadeiro com ela, eu avisava o horário, se eu fosse atrasar, eu ligava avisando, apesar que ela não acreditava muito (...) acho que toda mulher tem um pé atrás, porque homem é um bicho esquisito também" P52

A inexistência de traição e de mentiras na relação foi indicada por alguns participantes. É importante refletir com esses homens se eles estão naturalizando a infidelidade na relação ou se realmente ela não está acontecendo. Na pesquisa de Guimarães (2009), a infidelidade foi relatada pela maioria das mulheres participantes como uma prática comum dos ex/parceiros e que favoreceu a instalação e manutenção da violência conjugal.

Diversos autores (Buompadre, 2013; Manzanares \& Salgado, 2013; Souzas \& Alvarenga, 2001) correlacionam a violência e infidelidade, pelo fato de os dois fenômenos terem em comum vários fatores multicausais, dentre eles, as concepções estereotipadas de gênero. A infidelidade é valorizada para os homens e não é permitida para as mulheres em vários contextos estruturados pela desigualdade de gênero. 
Para Separavich e Canesqui (2013), o direito à infidelidade faz parte de uma longa lista de justificação da violência que revela a relação assimétrica estabelecida na conjugalidade, que têm o homem como provedor e no papel de dominação e a mulher como subordinada. A infidelidade configura como uma prática masculina aceita na dinâmica conjugal e representa um mecanismo de afirmação da masculinidade para muitos homens, que fortalece a desigualdade de gênero e justifica a instalação da violência conjugal. A descoberta da infidelidade pode ser uma das portas de entrada para o surgimento de conflitos e brigas conjugais, e, consequentemente, de outras agressões (Souzas \& Alvarenga, 2001).

Dentre os participantes da segunda etapa, 11 indicaram negação da violência quando apontaram as diferenças entre as vivências: "Tudo."; "Tudo"; "Ele tem 2 personalidades, eu nunca desvalorizei minha esposa"; "Nós nos amamos sempre e ainda nos amamos"; "Tudo"; "Eu nunca agredi minha esposa, meu sobrinho que levou ela na delegacia, ela quis tirar depois"; "Não tem nada a ver com a minha"; "Tudo"; "Tudo é diferente"; "Em meu relacionamento sempre existiu diálogo, compreensão e respeito"; "Tudo". Entendemos que a naturalização acontece, especialmente, quando os participantes não conseguem identificar nada como semelhante ou diferente quando juntamos as duas respostas dos homens sobre a comparação das histórias pessoais e a do livro. Seis homens $(19,26,34,46,50,51)$ mencionaram que não tinha nada parecido e que tudo era diferente ao realizarem essa comparação.

A socialização masculina favorece essa negação e minimização da violência (Oliveira \& Gomes, 2011). A negação ocorre quando a pessoa não percebe a violência e a minimização acontece quando a pessoa banaliza ou diminui os efeitos das agressões. Assim, ela não reconhece a sua gravidade (Lila et al., 2012).

Essa negação ou minimização é muito frequente, inclusive, entre participantes de grupos de homens autores de violência conjugal. Eles tendem a compreender as agressões cometidas por eles mesmos como qualitativamente diferentes e mais leves do que aquelas cometidas por outros homens que conheceram no acompanhamento (Chaves \& Silva, 2010; Ghesti-Galvão, Machado \& Costa, 2010; Moreira \& Matta, 2006; Rangel \& Tusi, 2010; Toneli et al., 2010). No caso dessa pesquisa, os homens mantiveram essa tendência ao comparar as suas histórias com os personagens do livro. Eles tiveram dificuldade de reconhecer a magnitude do impacto da violência às próprias parceiras e a si mesmo. Eles tiveram mais facilidade em identificar os prejuízos causados a outra mulher - no caso, a personagem Roz.

Outros participantes apresentaram respostas que podem indicar a desresponsabilização pela violência cometida ao comparar as vivências pessoais com a história dos personagens do livro. Na segunda etapa, seis participantes descreveram algum aspecto que pode indicar a sua 
desresponsabilização da violência: "A minha história eu já tinha separado e arrumei outra namorada. Ela mentia, não aceitou e brigou com minha atual e eu separei a briga e ela me denunciou."; “A gente está junto por causa do filho.”; "É que eu trabalhava e trabalhava e hoje luto para retornar a trabalhar. Não por causa da minha mulher, mas sim por causa da situação que ela me colocou."; "O intrometimento dos familiares dela, ou seja, pai e mãe e colegas"; "Eu tive diálogo. Na minha teve fingimento"; “A violência cometida teve a intenção de conter".

Essa desresponsabilização pela violência é outro fenômeno muito frequente de naturalização das agressões (Alves et al., 2012; Nascimento et al., 2009; Oliveira \& Gomes, 2011). Algumas narrativas dos participantes exemplificam esse processo de desresponsabilização pessoal da violência:

“A nossa história é tudo igual, homem é tudo igual, sempre tem bebida e outra mulher no meio, daí vem as confusões" P45

"Eu nunca aprontei com outra mulher, o meu problema foi com a bebida, ainda bem que eu parei, agora tudo tá bem" P36

A justificação e a externalização da violência são as principais características da desresponsabilização e são utilizadas para explicar a ocorrência da violência conjugal, geralmente baseada nos padrões da masculinidade hegemônica (Almeida, 1995; Connell, 1997; Separavich \& Canesqui, 2013; Silveira et al., 2009; Teixeira, 2009). Diversos pesquisadores (Alves \& Diniz, 2005; Araújo, 2012; Lila et al., 2012; Macedo, 2013; Ramos, 2013; Siqueira, 2012) apontam que os principais motivos para o uso da violência contra suas ex/companheiras geralmente são entendidos por eles como justificativas socialmente aceitáveis como forma de estratégias de defesa, de comunicação inadequada da frustração quanto ao relacionamento e quanto ao que eles consideram inadequados ao papel atribuído ao feminino.

A última categoria dessa comparação foi o início do processo de reconhecimento da violência na relação. Alguns participantes conseguiram descrever respostas que indicaram alguma reflexão sobre a sua responsabilização das agressões ao relatar a diferença entre suas histórias pessoais e a do livro. Na segunda etapa, sete participantes conseguiram descrever algum processo de reconhecimento da violência na relação nas respostas sobre as diferenças entre as vivências: "Muito pouco."; "Nada"; "Era o contrário, eu a amava demais e ela nunca quis, mas eu não conseguia enxergar."; “A minha história é igual a essa"; "Minha história é igual”; "Quase nada, muito parecido"; "Não tinha diálogo nenhum". As narrativas dos participantes exemplificam esse início do processo de reconhecimento da violência:

"Quando eu falo que não apronto mais, que eu parei de pegar mulher fora, os meus amigos nem acreditam. Eu to fazendo isso pra não ter problema mais em casa, to em paz agora" P34

"Eu era igual ao livro mesmo, eu nunca elogiava, nunca percebia uma unha pintada, um cabelo cortado. Eu achava que quem percebia essas coisas era bicha: 'ah o cara tá 
reparando que ela cortou um dedo do cabelo', eu já achava que o cara era veado, era um gay mesmo. Eu passei a prestar atenção mais nisso hoje, ela gosta muito. Por essas coisinhas é que a gente tá bem hoje” P39

A comparação entre as semelhanças e diferenças das histórias pessoais e a do livro foi uma oportunidade de estimular que os participantes trouxessem à tona as principais questões que favorecem a naturalização da violência em suas relações. Esse processo de reflexão indireta permite a manifestação de mecanismos de negação, minimização e desresponsabilização de homens autores de violência (Nascimento et al., 2009; Silveira et al., 2009; Toneli et al., 2010).

A naturalização da violência é uma questão extremamente complexa e favorece a perpetuação das agressões. Oliveira e Gomes (2011) afirmam que a falta de responsabilização dos homens em relação às agressões atua em prol da manutenção ou escalada da violência. Consideramos, então, ser de fundamental importância ajudar esses homens a manifestarem a naturalização das agressões para, posteriormente, terem condições de repensar e, até mesmo, desconstruir a relação entre violência, masculinidades e conjugalidades como um dos passos rumo a relações mais igualitárias em suas relações conjugais.

Tentamos construir uma proposta metodológica criativa e mais atrativa aos homens. De acordo com as ideias de Lima e Büchele (2011), é preciso escutar os homens de forma diferenciada e não apenas responsabilizá-los. Essa escuta deve incluir várias dimensões que transcendem o indivíduo e contenha as dimensões sociais e culturais da violência (Medrado \& Lyra, 2008). Esse pode ser um meio de refletir sobre alguns elementos dessa naturalização da violência e ir além da punição, prisão ou responsabilização/ressocialização dos homens (Medrado, 2010).

Nós consideramos que as categorias discutidas acima podem indicar a naturalização da violência, mas em muitos casos as vivências dos homens realmente podem ser menos graves que a do livro. O intuito foi de favorecer a manifestação de alguns indícios de negação, minimização e desresponsabilização da violência pelos homens autores para que essa naturalização possa ser posteriormente trabalhada como material clínico no contex to do acompanhamento psicossocial.

Não tivemos a pretensão de que os participantes conseguiriam trazer todos os aspectos da negação, minimização e/ou desresponsabilização da violência de sua dinâmica relacional. No entanto, acreditamos que essa comparação entre as vivências pessoais e a história do livro seja um importante passo no intuito de favorecer a manifestação de alguns aspectos que indicam a naturalização das agressões pelos homens.

Essa proposta de intervenção contribuiu nesse sentido, mas temos a consciência de que um processo de mudanças deve ser incluído em um contexto maior de acompanhamento psicossocial. Estudos futuros podem focar na intervenção com homens a partir dessas manifestações de naturalização da violência como meio de ajudar no início ou na ampliação do processo de 
mudanças, de empoderamento e de transformações pessoais e relacionais para superação da violência, inclusive dos participantes que trouxeram grande tendência a naturalizar a violência (Aguiar, 2009; Araújo, 2012; Figueira, 2012; Macedo, 2013; Lila, Gracia \& Herrero, 2012; Oliveira \& Gomes, 2011; Silveira et al., 2009).

\section{Anestesias relacionais de homens autores de violência}

O objetivo das perguntas 4, 5 e 6 do questionário foi identificar anestesias relacionais que favoreceram a permanência de homens em um relacionamento marcado pela violência e/ou a dificuldade em pedir ajuda a terceiros ou às instituições. Na quarta e quinta perguntas os participantes puderam escolher as anestesias que identificaram como presentes em suas próprias histórias. Essas anestesias estavam demonstradas em um anexo contendo pensamentos, sentimentos e ilustrações apresentados pela personagem nas contracapas do livro na primeira etapa da pesquisa ou por meio de estímulos que foram apresentados por outros homens autores de violência na segunda etapa. Os anexos serviram como estímulos para facilitar a identificação das anestesias pelos participantes e foi entregue junto com o questionário conforme apresentado nos Anexos I ao IV. Como o questionário da segunda etapa foi construído a partir das anestesias levantadas pelos participantes da primeira etapa, apresentaremos inicialmente os resultados dessa etapa e, em seguida, da segunda.

Vale relembrar que as anestesias relacionais são ideias, sentimentos e ações que contribuem para a permanência de mulheres e de homens na situação de violência conjugal. A resposta esperada de pessoas que entram em contato com uma situação de violência social ou familiar - sejam como testemunhas ou como diretamente envolvidas - é sentir dor, indignação, raiva, impotência e vergonha. A experiência do mal-estar levaria a algum tipo de reação no sentido de interrompê-la. A presença das anestesias impede ou dificulta essa reação, pois as pessoas naturalizam os impactos da violência em suas vidas por meio da negação, minimização ou desresponsabilização das agressões. Por isso, é fundamental estimular a manifestação e a reflexão sobre essas anestesias para superação da violência nas relações conjugais (Ravazzola, 1997, 1998, 2015).

\section{Anestesias relacionais dos participantes da $1^{a}$ Etapa}

A Tabela 6.9 revela as anestesias relacionais mais marcadas pelos homens da primeira etapa. Apresentamos as anestesias que foram marcadas por pelo menos quatro participantes. As anestesias que os homens mais se identificaram foram: “Onde foi que eu errei?”, "Quem disse que a vida é fácil?", "Ele jura que não vai acontecer de novo...” e "Talvez ele melhore...”. 
Tabela 6.9

Anestesias mais Marcadas pelos Participantes da $1^{a}$ Etapa

\begin{tabular}{ccc}
\hline & Anestesias & Quantidade \\
\hline 1. & Onde foi que eu errei? & 8 \\
2. & Quem disse que a vida é fácil? & 7 \\
3. & Ele jura que não vai acontecer de novo... & 6 \\
4. & Talvez ele melhore... & 6 \\
5. & Talvez eu deva falar menos... & 5 \\
6. & Talvez só esteja estressado & 5 \\
7. & Se eu fosse mais compreensiva... & 5 \\
8. & A culpa não é dele. & 5 \\
9. & Quem acreditaria em mim? & 4 \\
10. & Ele pediu desculpas... & 4 \\
11. & Ele só tomou umas cervejas... & 4 \\
12. & Como posso abandonar as crianças? & 4 \\
13. & E se eu for o problema? & 4 \\
14. & Não é uma pessoa má. & 4 \\
15. & Se eu me esforçar mais... & 4 \\
\hline
\end{tabular}

Dentre as 35 anestesias listadas no livro, 33 foram marcadas pelo menos uma vez. Somente duas não foram selecionadas pelos homens: "E vinho no jantar" e "Talvez eu seja sensível demais...". Duas anestesias foram citadas por mais da metade dos 13 participantes: "Onde foi que eu errei?" e "Quem disse que a vida é fácil?”. O que indica um alto reconhecimento de sua influência na manutenção da violência conjugal pelos homens autores de violência.

A Tabela 6.10 mostra a quantidade de anestesias relacionais marcada por cada participante. A quantidade de anestesias selecionada variou entre 3 a 19 dentre as 35 opções listadas pela autora do livro.

Tabela 6.10

Quantidade de Anestesias Marcadas por cada Participante da $1^{a}$ Etapa

\begin{tabular}{cc}
\hline Participante & Quantidade \\
\hline $\mathbf{1 .}$ & 3 \\
$\mathbf{2 .}$ & 4 \\
$\mathbf{3 .}$ & 7 \\
$\mathbf{4 .}$ & 3 \\
$\mathbf{5 .}$ & 8 \\
$\mathbf{6 .}$ & 3 \\
$\mathbf{7 .}$ & 17 \\
$\mathbf{8 .}$ & 10 \\
$\mathbf{9 .}$ & 18 \\
$\mathbf{1 0}$. & 4 \\
$\mathbf{1 1 .}$ & 4 \\
$\mathbf{1 2 .}$ & 19 \\
$\mathbf{1 3 .}$ & 9 \\
\hline
\end{tabular}

A Tabela 6.11, derivada da tabela anterior, apresentou a comparação da quantidade de anestesias relacionais marcadas pelos participantes. A média foi de 8,98 anestesias por cada 
homem. Essa média mostra que alguns homens participantes tiveram identificação com os pensamentos, sentimentos e ações da personagem.

Tabela 6.11

Comparação da Quantidade de Anestesias Marcadas por Cada Participante da $1^{a}$ Etapa

\begin{tabular}{cc}
\hline & Total \\
\hline Média & 8,38 \\
Mínima & 3 \\
Máxima & 19 \\
\hline
\end{tabular}

Consideramos ser importante saber quais foram as anestesias que os participantes consideraram mais influentes em suas histórias a partir do estímulo do livro. A pergunta 5 do questionário tinha o comando para os homens escolherem três das 35 anestesias que eles perceberam como mais importantes na vivência da relação marcada pela violência. A Tabela 6.12 exibe essas anestesias relacionais. Apresentamos as anestesias que foram apontadas por pelo menos dois participantes.

Tabela 6.12

Anestesias Consideradas Mais Influentes pelos Participantes da $1^{a}$ Etapa

\begin{tabular}{cll}
\hline \multicolumn{1}{c}{ Anestesias } & $\mathbf{N}^{\circ}$ de Participantes \\
\hline 1. & Quem disse que a vida é fácil? & 4 \\
2. & Onde foi que eu errei? & 4 \\
3. & Talvez eu deva falar menos... & 3 \\
4. & Talvez ele melhore... & 3 \\
5. & Eu não deveria perdoar? & 2 \\
6. & Ele pediu desculpas... & 2 \\
7. & Como posso abandonar as crianças? & 2 \\
8. & Talvez só esteja estressado & 2 \\
9. & Ele jura que não vai acontecer de novo... & 2 \\
10. & E se eu for o problema? & 2 \\
\hline
\end{tabular}

A maioria dos participantes escolheu e escreveu até três anestesias no campo apropriado do questionário. Das 35 anestesias do livro, 19 foram apontadas como mais importantes pelos homens. As anestesias mais relevantes na visão dos próprios participantes foram "Quem disse que a vida é fácil?”; “Onde foi que eu errei?”; “Talvez eu deva falar menos...” e "Talvez ele melhore...”.

O objetivo da pergunta 6 do questionário foi averiguar quais anestesias os participantes consideravam importantes a partir de suas próprias histórias, ou seja, eles tinham a opção de acrescentar anestesias advindas de sua própria experiência e que não estavam listadas no estímulo fornecido. A pergunta era se os homens tinham algum pensamento ou sentimento além daqueles que foram citados pela protagonista do livro. Caso os homens respondessem que "sim", o questionário dava a eles a opção de preencher até três campos com as suas anestesias. 
A Tabela 6.13 expõe as anestesias relacionais identificadas pelos próprios homens, sem os estímulos das anestesias do livro. Os participantes conseguiram levantar 19 anestesias.

Tabela 6.13

Anestesias Próprias dos Participantes da $1^{a}$ Etapa - Sem Estímulos

\begin{tabular}{|c|c|c|}
\hline & Anestesias & Quantidade por participante \\
\hline 1. & $\begin{array}{l}\text { Ela é muito sensível } \\
\text { Eu ainda gosto dela } \\
\text { Não me ama, mas sempre precisa de mim }\end{array}$ & 3 \\
\hline 2. & A culpa foi minha (álcool) & 1 \\
\hline 3. & $\begin{array}{l}\text { Ninguém nasce má } \\
\text { Ela era tudo pra mim }\end{array}$ & 2 \\
\hline 4. & Eu não vou perder minha família & 1 \\
\hline 5. & - & 0 \\
\hline 6. & $\begin{array}{l}\text { Não sei se invisto ou saio } \\
\text { A gente bebia muito } \\
\text { Eu era muito ciumento } \\
\text { A gente trabalha junto }\end{array}$ & 4 \\
\hline 7. & - & 0 \\
\hline 8. & - & 0 \\
\hline 9. & $\begin{array}{l}\text { Envolvimento familiar (para sair do relacionamento) } \\
\text { Vergonha, falta de oportunidade (pedir ajuda) } \\
\text { Falta coragem, falta diálogo, pulso firme, pé no chão }\end{array}$ & 3 \\
\hline 10. & $\begin{array}{l}\text { Ela não precisava chamar a polícia } \\
\text { Mas ela é minha mulher }\end{array}$ & 2 \\
\hline 11. & - & 0 \\
\hline 12. & - & 0 \\
\hline 13. & $\begin{array}{l}\text { Desabafo } \\
\text { Ódio } \\
\text { Arrependimento } \\
\text { Total }\end{array}$ & 19 \\
\hline
\end{tabular}

A Tabela 6.14 detalha a tabela anterior. Ela revela a quantidade de anestesias próprias identificadas por cada participante. Essa quantidade variou de nenhuma a quatro. O instrumento oferecia três campos para inclusão de anestesias próprias, mesmo assim um participante incluiu mais uma anestesia que considerou importante.

Tabela 6.14

Quantidade de Anestesias Próprias dos Participantes da $1^{a}$ Etapa Quantidade de anestesias próprias $\quad 1^{\mathrm{a}}$ Etapa

\begin{tabular}{cc}
\hline Nenhuma & 5 \\
Uma & 2 \\
Duas & 3 \\
Três & 2 \\
Quatro & 1 \\
\hline
\end{tabular}

A partir das 19 anestesias relacionais identificadas pelos próprios homens na primeira etapa e de outras que foram apresentados pelo Brian, em reunião de equipe de orientação do doutorado nós selecionamos as que representavam a negação, minimização e desresponsabilização da violência. Essas categorias foram criadas de acordo com os objetivos da pesquisa, no intuito de verificar como os homens da segunda etapa manifestariam indícios de anestesias relacionais por meio da naturalização da violência. 
A lista abaixo mostra as anestesias selecionadas. Com o objetivo de facilitar a diferenciação das anestesias dos homens e do personagem do livro, as que estão em negrito são dos participantes da primeira etapa e as sem destaque são do Brian.

Categoria 1: Negação

1. Ela é muito sensível

2. Mas ela é minha mulher

3. Ela não precisava chamar a polícia

4. Eu não vou perder minha família

5. Quero que nós dois viremos um só...

6. Eu fiz mesmo essas coisas? Não me lembro..

7. Não acredito que magoei você desse jeito...

8. Não desista de nós logo agora, meu amor...

Categoria 2: Minimização da violência

1. Eu ainda gosto dela

2. Ela era tudo pra mim

3. Me perdoa, não vai se repetir.

4. Pode ser paciente comigo?

5. Não vai acontecer de novo... Eu juro!

6. Nosso amor não significa nada para você?

7. Eu te amo... Nunca quis magoar você...

8. Não jogue fora nosso amor.

9. Você precisa me dar mais uma chance... Por favor!

10. Tudo vai mudar, eu juro! Não posso perder você...

Categoria 3: Desresponsabilização

\section{Não me ama, mas sempre precisa de mim}

2. A gente bebia muito

3. Eu era muito ciumento

4. Se você largar o seu emprego, terá mais tempo para nós.

5. Eu não quero que você fale com os vizinhos!

6. Confie em mim, amor. Sei o que é melhor para você.

7. Mas ela sempre diz a coisa errada.

8. Nunca percebe meu estado de espírito...

9. Você não passa de uma vadia!

10. Você tem que aprender a se cuidar melhor!

11. Se você depuser contra mim... Posso até ser preso!

12. Pense nas crianças.

13. Você nunca vai encontrar um homem que tenha mais amor para dar...

Algumas dessas anestesias podem significar mais de um tipo de naturalização dependendo do contexto que forem utilizadas. Nós alocamos cada uma nas respectivas categorias cientes de que poderiam significar outro sentido. Concordamos com Silveira et al. (2009), que defendem que as categorias não podem ser estanques e nem excludentes, elas podem e devem apresentar diversas 
tensões e correlações em vários momentos.

A partir dessa lista, os participantes da segunda etapa poderão ter opções para escolher anestesias criadas por outros homens autores de violência: do personagem do livro e dos participantes da primeira etapa. Os estímulos não seriam mais de uma mulher vítima como aconteceu na primeira etapa, mas de homens em situação semelhante - que vivenciaram o papel de autores de violência conjugal.

As anestesias apresentadas no instrumento para a segunda etapa foram listadas na seguinte ordem para que as anestesias das três categorias ficassem alternadas: Ela é muito sensível; Eu ainda gosto dela; Não me ama, mas sempre precisa de mim; Mas ela é minha mulher; Ela era tudo pra mim; A gente bebia muito; Ela não precisava chamar a polícia; Me perdoa, não vai se repetir.; Eu era muito ciumento; Eu não vou perder minha família; Pode ser paciente comigo?; Se você largar o seu emprego, terá mais tempo para nós.; Quero que nós dois viremos um só...; Não vai acontecer de novo... Eu juro!; Eu não quero que você fale com os vizinhos!; Eu fiz mesmo essas coisas? Não me lembro...; Nosso amor não significa nada para você?; Confie em mim, amor. Sei o que é melhor para você.; Não acredito que magoei você desse jeito...; Eu te amo... Nunca quis magoar você...; Mas ela sempre diz a coisa errada.; Não desista de nós logo agora, meu amor...; Não jogue fora nosso amor.; Nunca percebe meu estado de espírito...; Você precisa me dar mais uma chance... Por favor!; Você não passa de uma vadia!; Tudo vai mudar, eu juro! Não posso perder você...; Você tem que aprender a se cuidar melhor!; Se você depuser contra mim... Posso até ser preso!; Pense nas crianças.; Você nunca vai encontrar um homem que tenha mais amor para dar...

A questão quatro do segundo questionário foi acompanhada por um material anexo - uma xérox de 31 anestesias (Anexo IV) que foram apresentadas pelo personagem do livro e pelos participantes da primeira etapa. Essas anestesias foram disponibilizadas no anexo de forma semelhante à primeira etapa, em formato de quadrinhos contendo o rosto, as expressões, os pensamentos e os sentimentos do personagem Brian. Esses quadrinhos foram adaptados por solicitação do doutorando a um profissional de design gráfico para manter a maior semelhança possível do anexo do primeiro questionário. Após a contextualização do procedimento de construção desse questionário, podemos discutir as anestesias relacionais apresentadas pelos participantes da segunda etapa da pesquisa.

\section{Anestesias relacionais dos participantes da $2^{a}$ Etapa}

A Tabela 6.9A revela as anestesias relacionais mais marcadas pelos homens da segunda etapa. Apresentamos as anestesias que foram marcadas por pelo menos 15 participantes, que representa um terço do número total de homens. As anestesias que eles mais se identificaram foram: 
"Ela não precisava chamar a polícia", "Eu te amo... Nunca quis magoar você..." e "Eu não vou perder minha família”.

Tabela 6.9A

Anestesias mais Marcadas pelos Participantes da $2^{a}$ Etapa

\begin{tabular}{ccc}
\hline & Anestesias & Quantidade \\
\hline 1. & Ela não precisava chamar a polícia & 28 \\
2. & Eu te amo... Nunca quis magoar você... & 20 \\
3. & Eu não vou perder minha família & 19 \\
4. & Eu ainda gosto dela & 18 \\
5. & Não vai acontecer de novo... Eu juro! & 18 \\
6. & Pense nas crianças. & 17 \\
7. & Não jogue fora nosso amor. & 16 \\
8. & Ela era tudo pra mim & 15 \\
9. & Pode ser paciente comigo? & 15 \\
\hline
\end{tabular}

Dentre as 31 anestesias listadas no questionário, 30 foram marcadas pelo menos uma vez. Somente uma não foi selecionada pelos homens da segunda etapa: "Se você largar o seu emprego, terá mais tempo para nós.”. Uma anestesia foi citada por mais da metade dos 45 participantes: "Ela não precisava chamar a polícia". Outras seis foram mencionadas por mais de um terço dos homens: "Eu te amo... Nunca quis magoar você..."; "Eu não vou perder minha família"; "Eu ainda gosto dela"; "Não vai acontecer de novo... Eu juro!"; "Pense nas crianças."; "Não jogue fora nosso amor.", o que indica um alto reconhecimento de sua influência na manutenção da violência conjugal pelos homens autores de violência da segunda etapa. No intuito de facilitar a diferenciação das anestesias do questionário que foram selecionados a partir de anestesias dos homens da primeira etapa e as do personagem do livro, as que estão em negrito são dos participantes e as sem destaque são do Brian.

Essas anestesias mais selecionadas pelos participantes perpassam as três categorias criadas nesse estudo. Duas representavam a negação da violência: "Ela não precisava chamar a polícia"; e "Eu não vou perder minha família". Quatro são anestesias que indicam minimização da violência: "Eu te amo... Nunca quis magoar você..."; "Eu ainda gosto dela"; "Não vai acontecer de novo... Eu juro!"; e "Não jogue fora nosso amor.”. E uma indicou a desresponsabilização dos homens: "Pense nas crianças.".

A Tabela 6.10A mostra a quantidade de anestesias relacionais marcada por cada participante. A quantidade de anestesias selecionada variou entre 1 a 21 dentre as 31 opções listadas no questionário da segunda etapa. 
Tabela 6.10A

Quantidade de Anestesias Marcadas pelos Participantes da $2^{a}$ Etapa

\begin{tabular}{cc}
\hline & Quantidade \\
\hline 0 a 10 & 29 \\
11 a 20 & 14 \\
>20 & 2 \\
\hline
\end{tabular}

A Tabela 6.11A, derivada da tabela anterior, apresentou a comparação da quantidade de anestesias relacionais marcadas pelos participantes. A média foi de 8,2 anestesias por cada homem. Essa média mostra que muitos homens participantes tiveram alta identificação com os pensamentos, sentimentos e ações do personagem do livro e dos homens da primeira etapa.

Tabela 6.11A

Comparação da Quantidade de Anestesias Marcadas por Cada Participante da $2^{a}$ Etapa

\begin{tabular}{cc}
\hline & Total \\
\hline Média & 8,2 \\
Mínima & 1 \\
Máxima & 21 \\
\hline
\end{tabular}

Consideramos ser importante saber quais foram as anestesias que os participantes consideraram mais influentes em suas histórias a partir do estímulo do livro. A pergunta 5 do questionário tinha o comando para os homens escolherem três das 31 anestesias que eles perceberam como mais importantes na vivência da relação marcada pela violência. A Tabela 6.12A exibe essas anestesias relacionais mais importantes na compreensão dos homens. Apresentamos as anestesias que foram apontadas por pelo menos cinco participantes.

Tabela 6.12A

Anestesias Consideradas Mais Influentes pelos Participantes da $2^{a}$ Etapa

\begin{tabular}{clc}
\hline \multicolumn{1}{c}{ Anestesias } & $\mathbf{N}^{\circ}$ de participantes \\
\hline 1. & Pense nas crianças. & 14 \\
2. & Ela não precisava chamar a polícia & 10 \\
3. & Eu ainda gosto dela & 10 \\
4. & Eu não vou perder minha família & 9 \\
5. & Ela é muito sensível & 7 \\
6. & Me perdoa, não vai se repetir. & 7 \\
7. & Eu era muito ciumento & 6 \\
8. & Não vai acontecer de novo... Eu juro! & 5 \\
9. & Eu te amo... Nunca quis magoar você... & 5 \\
10. & Não desista de nós logo agora, meu amor... & 5 \\
11. & Se você depuser contra mim... Posso até ser preso! & 5 \\
\hline
\end{tabular}

A maioria dos participantes escolheu e escreveu até três anestesias no campo apropriado do questionário. Das 31 anestesias listadas no instrumento da segunda etapa, 27 foram apontadas como mais importantes pelos homens. As anestesias mais relevantes na visão dos próprios participantes 
foram "Pense nas crianças."; "Ela não precisava chamar a polícia"; "Eu ainda gosto dela"; "Eu não vou perder minha família"; "Ela é muito sensível"; "Me perdoa, não vai se repetir.".

Essas anestesias consideradas como mais importantes pelos próprios participantes também incluem as três categorias criadas nesse estudo. Dez são anestesias selecionadas pelos homens como mais influentes em suas próprias vivências indicam minimização da violência. Essas anestesias são listadas na ordem decrescente de importância de acordo com as marcações dos participantes: “Eu ainda gosto dela" (10); "Me perdoa, não vai se repetir." (7); "Não vai acontecer de novo... Eu juro! (5); "Eu te amo... Nunca quis magoar você..." (5); "Ela era tudo pra mim" (4); "Você precisa me dar mais uma chance... Por favor!" (4); "Pode ser paciente comigo?" (3); "Nosso amor não significa nada para você?" (2); "Não jogue fora nosso amor.” (2); “Tudo vai mudar, eu juro! Não posso perder você..." (2).

Oito representavam a negação da violência: “Ela não precisava chamar a polícia” (14); "Eu não vou perder minha família" (9); "Ela é muito sensível” (7); "Não desista de nós logo agora, meu amor..." (5); "Não acredito que magoei você desse jeito..." (3); "Mas ela é minha mulher" (2); “Quero que nós dois viremos um só...” (1) e "Eu fiz mesmo essas coisas? Não me lembro..." (1).

Nove indicam a desresponsabilização dos homens: "Pense nas crianças." (14); “Eu era muito ciumento." (6); "Se você depuser contra mim... Posso até ser preso!" (5); "Não me ama, mas sempre precisa de mim" (4); "A gente bebia muito" (4); “Confie em mim, amor. Sei o que é melhor para você." (2); "Você tem que aprender a se cuidar melhor!" (2); "Você nunca vai encontrar um homem que tenha mais amor para dar..." (2); e "Mas ela sempre diz a coisa errada." (1).

O objetivo da pergunta 6 do questionário foi averiguar quais anestesias os participantes consideravam importantes a partir de suas próprias histórias, ou seja, eles tinham a opção de acrescentar anestesias advindas de sua própria experiência e que não estavam listadas no estímulo fornecido. A pergunta era se os homens tinham algum pensamento ou sentimento além daqueles que foram citados por outros homens autores - da primeira etapa da pesquisa ou do protagonista do livro. Caso os homens respondessem que "sim", o questionário dava a eles a opção de preencher até três campos com as suas anestesias.

A Tabela 6.13A expõe as anestesias relacionais identificadas pelos próprios homens, sem os estímulos das anestesias do livro. Os participantes conseguiram levantar 18 anestesias. 
Tabela 6.13A

Anestesias Próprias dos Participantes da $2^{a}$ Etapa - Sem Estímulos

\begin{tabular}{|c|c|c|}
\hline & Anestesias & Quantidade por participante \\
\hline 14. & Estresse e labor excessivo! & 1 \\
\hline 15. & - & 0 \\
\hline 16. & Ela que bebia muito, eu bebo pouco. & 1 \\
\hline 17. & $\begin{array}{l}\text { Eu que devia ter ido na delegacia } \\
\text { Eu não fiz nada }\end{array}$ & 2 \\
\hline 18. & Só eu que bebo & 1 \\
\hline 19. & - & 0 \\
\hline 20. & O que me impedia era a vergonha de pedir ajuda pra alguém & 1 \\
\hline 21. & - & 0 \\
\hline 22. & - & 0 \\
\hline 23. & $\begin{array}{l}\text { Eu nada faço } \\
\text { Não bebo e não saio às festas devido a essa situação }\end{array}$ & 2 \\
\hline 24. & Ela é muito ciumenta & 1 \\
\hline 25. & - & 0 \\
\hline 26. & - & 0 \\
\hline 27. & $\begin{array}{l}\text { De achar que está tudo bem, pois a pessoa não dizia que nada a } \\
\text { incomodava. } \\
\text { Sentimento de crer que tudo vai melhorar. }\end{array}$ & 2 \\
\hline 28. & - & 0 \\
\hline 29. & - & 0 \\
\hline 30. & $\begin{array}{l}\text { Conversas } \\
\text { Paciência } \\
\text { Humildade }\end{array}$ & 3 \\
\hline 31. & $\begin{array}{l}\text { O ato dela complementar a ajuda financeira } \\
\text { Ser parceiro e lembrar no dia de amanhã }\end{array}$ & 2 \\
\hline 32. & Acho que tudo estava escondido & 1 \\
\hline 33. & - & 0 \\
\hline 34. & - & 0 \\
\hline 35. & - & 0 \\
\hline 36. & O uso de bebida alcoólica & 1 \\
\hline 37. & - & 0 \\
\hline 38. & - & 0 \\
\hline 39. & $\begin{array}{l}\text { Bebidas, amigos e não ter compromisso } \\
\text { Ela me ama até hoje e eu também, mas só vamos retornar depois } \\
\text { do tratamento, começamos a fazer tratamento e me sinto mudando } \\
\text { muito }\end{array}$ & 2 \\
\hline 40. & - & 0 \\
\hline 41. & - & 0 \\
\hline 42. & - & 0 \\
\hline 43. & Ciúmes de ambas as partes, gerou conflito... & 1 \\
\hline 44. & Nós dois era ciumentos & 1 \\
\hline 45. & - & 0 \\
\hline 46. & - & 0 \\
\hline 47. & - & 0 \\
\hline 48. & - & 0 \\
\hline 49. & Pensamento de ter morte ou ter violência grave & 1 \\
\hline 50. & - & 0 \\
\hline 51. & $\begin{array}{l}\text { Sentimento de revolta } \\
\text { Sentimento de incapacidade }\end{array}$ & 2 \\
\hline 52. & $\begin{array}{l}\text { Mal conselhos dos amigo } \\
\text { Vizinhos }\end{array}$ & 2 \\
\hline 53. & - & 0 \\
\hline 54. & - & 0 \\
\hline 55. & - & 0 \\
\hline 56. & - & 0 \\
\hline 57. & - & 0 \\
\hline 58. & - & 0 \\
\hline
\end{tabular}

A Tabela 6.14A detalha a tabela anterior. Ela revela a quantidade de anestesias próprias identificadas por cada participante. Essa quantidade variou de nenhuma a três. A maioria dos participantes (27) não incluiu anestesias próprias. Esse fato pode revelar uma negação da violência, pois sem estímulos muitos homens não conseguiram pensar a violência. 
Tabela 6.14A

Quantidade de Anestesias Próprias dos Participantes da $2^{a}$ Etapa

\begin{tabular}{cc}
\hline Quantidade de anestesias próprias & Total \\
\hline Nenhuma & 27 \\
Uma & 10 \\
Duas & 7 \\
Três & 1 \\
\hline
\end{tabular}

Esse breve resumo das questões quantitativas das anestesias foi realizado para ilustrar e organizar essas informações sobre os participantes. Essas informações são importantes, mas não são suficientes para alcançar o objetivo desse trabalho.

O nosso enfoque qualitativo favorece a análise sobre os significados dessas anestesias. Realizamos, então, uma categorização dos pensamentos, sentimentos e ações que nos permitiu agregar as anestesias que os participantes consideraram mais influentes - a partir da Tabela 6.12A e as anestesias próprias sem estímulos - Tabela 6.13A.

A Tabela 6.15 foi elaborada após a realização da analise de conteúdo (Bardin, 2004; Bauer, 2002; Minayo, 1998, 2001; Romeu, 2001; Seidl de Moura \& Ferreira, 2005) das respostas em conjunto das anestesias relacionais consideradas mais influentes e as criadas pelos próprios participantes da segunda etapa. A partir das respostas dos participantes foram criadas quatro categorias de anestesias que os próprios homens autores de violência criaram e/ou consideraram como mais influentes e impactantes em suas vivências conjugais:

- Desresponsabilização do homem;

- Minimização da violência;

- Negação da violência; e

- Início do processo de reconhecimento da violência/responsabilização.

Essas categorias dos participantes da segunda etapa estão destacadas na Tabela 6.15 e são discutidas a seguir, de acordo com a ordem decrescente de quantidade de anestesias. Nós diferenciamos os tipos de anestesias na segunda coluna para facilitar a visualização na tabela a seguir. As anestesias citadas pelos participantes a partir de estímulos do personagem do livro - que também configurou como autor de violência - estão sem destaque. As anestesias dos participantes da primeira etapa estão em negrito. As anestesias criadas pelos homens da segunda etapa foram colocadas em itálico. O número entre parênteses da Tabela 6.15 mostra a quantidade de participantes que indicaram a anestesia relacional como mais influentes em suas próprias vivências - essa quantidade foi extraída da Tabela 6.12A. 
Tabela 6.15

Categorização das Anestesias Mais influentes e Anestesias Próprias dos Participantes da $2^{a}$ Etapa

\begin{tabular}{|c|c|}
\hline Desresponsabilização & $\begin{array}{l}\text { Pense nas crianças (14) } \\
\text { Eu era muito ciumento (6) } \\
\text { Se você depuser contra mim... Posso até ser preso! (5); } \\
\text { Não me ama, mas sempre precisa de mim" (4) } \\
\text { A gente bebia muito" (4) } \\
\text { Confie em mim, amor. Sei o que é melhor para você (2) } \\
\text { Você tem que aprender a se cuidar melhor! (2) } \\
\text { Você nunca vai encontrar um homem que tenha mais amor para } \\
\text { dar... (2) } \\
\text { Mas ela sempre diz a coisa errada (1) } \\
\text { Estresse e labor excessivo! } \\
\text { Ela que bebia muito, eu bebo pouco. } \\
\text { Eu que devia ter ido na delegacia } \\
\text { Só eu que bebo } \\
\text { Não bebo e não saio às festas devido a essa situação } \\
\text { Ela é muito ciumenta } \\
\text { O ato dela complementar a ajuda financeira } \\
\text { Acho que tudo estava escondido } \\
\text { O uso de bebida alcoólica } \\
\text { Bebidas, amigos e não ter compromisso } \\
\text { Ciúmes de ambas as partes, gerou conflito... } \\
\text { Nós dois era ciumentos } \\
\text { Mal conselhos dos amigo } \\
\text { Vizinhos }\end{array}$ \\
\hline Minimização & $\begin{array}{l}\text { Eu ainda gosto dela (10) } \\
\text { Me perdoa, não vai se repetir. (7) } \\
\text { Não vai acontecer de novo... Eu juro! (5) } \\
\text { Eu te amo... Nunca quis magoar você... (5) } \\
\text { Ela era tudo pra mim (4) } \\
\text { Você precisa me dar mais uma chance... Por favor! (4) } \\
\text { Pode ser paciente comigo? (3) } \\
\text { Nosso amor não significa nada para você? (2) } \\
\text { Não jogue fora nosso amor. (2) } \\
\text { Tudo vai mudar, eu juro! Não posso perder você... (2) } \\
\text { De achar que está tudo bem, pois a pessoa não dizia que nada a } \\
\text { incomodava. } \\
\text { Sentimento de crer que tudo vai melhorar. } \\
\text { Ser parceiro e lembrar no dia de amanhã }\end{array}$ \\
\hline Negação & $\begin{array}{l}\text { Ela não precisava chamar a polícia (14) } \\
\text { Eu não vou perder minha família (9) } \\
\text { Ela é muito sensível (7) } \\
\text { Não desista de nós logo agora, meu amor... (5) } \\
\text { Não acredito que magoei você desse jeito..." (3) } \\
\text { Mas ela é minha mulher (2) } \\
\text { Quero que nós dois viremos um só... (1) } \\
\text { Eu fiz mesmo essas coisas? Não me lembro... (1) } \\
\text { Eu não fiz nada } \\
\text { Eu nada faço }\end{array}$ \\
\hline Início do processo de reconhecimento & $\begin{array}{l}\text { O que me impedia era a vergonha de pedir ajuda pra alguém } \\
\text { Conversas } \\
\text { Paciência } \\
\text { Humildade } \\
\text { Ela me ama até hoje e eu também, mas só vamos retornar depois } \\
\text { do tratamento, começamos a fazer tratamento e me sinto mudando } \\
\text { muito } \\
\text { Pensamento de ter morte ou ter violência grave } \\
\text { Sentimento de revolta } \\
\text { Sentimento de incapacidade }\end{array}$ \\
\hline
\end{tabular}

Diversas respostas indicaram a desresponsabilização do homem, especialmente as que apontavam a culpabilização da mulher. As anestesias que indicam essa desresponsabilização de homens são: "Pense nas crianças."; "Eu era muito ciumento."; "Se você depuser contra mim... Posso até ser preso!"; "Não me ama, mas sempre precisa de mim"; "A gente bebia muito"; “Confie em mim, amor. Sei o que é melhor para você."; "Você tem que aprender a se cuidar 
melhor!"; "Você nunca vai encontrar um homem que tenha mais amor para dar..."; e "Mas ela sempre diz a coisa errada.; "Estresse e labor excessivo!"; "Ela que bebia muito, eu bebo pouco."; "Eu que devia ter ido na delegacia”; "Só eu que bebo"; "Não bebo e não saio às festas devido a essa situação"; "Ela é muito ciumenta"; "O ato dela complementar a ajuda financeira"; "Acho que tudo estava escondido"; "O uso de bebida alcoólica”; "Bebidas, amigos e não ter compromisso"; "Ciúmes de ambas as partes, gerou conflito...”; "Nós dois era ciumentos”; "Mal conselhos dos amigo"; "Vizinhos".

$\mathrm{O}$ relato de somente a mulher ter que pensar nas crianças, ela ter ciúmes, o interesse financeiro da ex-companheira, ela não saber se cuidar, ela mentir ou omitir, ela dizer a coisa errada, e a compreensão enviesada da mulher como propriedade dos homens são elementos das respostas dos participantes que indicaram meios para culpabilizar as ex/parceiras e para justificar a violência. Outras características foram apontadas para externalizar a responsabilidade da violência pelos homens: trabalhar muito, abusar de álcool, ter ciúmes, intromissão da família, amigos ou vizinhos. Por último, alguns homens descreveram uma inversão da culpabilização e a sua colocação no papel de vítima das agressões: perceberam que a sua prisão dependia da parceira (e não de seus atos agressivos), que ele é quem deveria ir à delegacia, que era muito bom para ela ou que ele sabe o que é melhor para a mulher. Algumas narrativas dos participantes durante a reflexão grupal ilustram bem essa desresponsabilização da violência:

"Eu coloquei [na resposta à pergunta 6] sobre os amigos, os vizinhos e a família, pra não deixar a família ficar intrometendo na sua mente, senão a gente acaba fazendo bobagem também. Se a gente pegar o nosso problema e conta pra um, leva pra outro, quando junta no final não dá nada de bom" P52

"Acaba que eu tô com outra parceira, já é a décima segunda mulher que eu larguei, eu gostava de levar ela pro boteco, aqueles copos sujos, ai não tinha jeito, era briga mesmo. Eu levantava pra ir no banheiro, um cara mexia com ela, ela é bonita, os cara caem matando. Parece que ela gostava que eu mostrasse ciúme dela, pra ter certeza que o cara ama ela. Ela ia só pra ver se o fulano vai cobrar ciúme de mim (...) Mas ai o pau comia no boteco mesmo, eu batia no cara e nela, nem esperava chegar em casa. Eu falava, 'ah sua vadia, você tá defendendo o cara?' Eu dava uns tabefes na orelha dela ali na frente de todo mundo, pra mostrar que não podia ser assim. Por isso eu marquei esse da vadia, porque se a mulher for vadia, tem que apanhar mesmo (...) Só que agora eu to nessa escolinha [grupo], que tá sendo muito boa pra mim, eu to mudando, quando a atual fala grosso comigo, eu respondo logo, pode deixar que eu lavo as vasilha rapidinho (risadas), e eu tô lavando mesmo. Eu me raciocinei nesse caso, com a minha atual e não levo ela pra boteco, só vou pra lanchonete, no máximo, um barzinho de ambiente familiar, nunca pra copo sujo. Tá funcionando" P49

Essas anestesias de desresponsabilização indicam que em uma sociedade machista tudo pode ser utilizado como justificativa para agredir a parceira e/ou para a manutenção da relação marcada pela violência, inclusive questões contraditórias. Alguns homens utilizaram como justificativas o 
fato da mulher depender financeiramente dele, outro homem justificou a manutenção da relação pelo fato de a esposa complementar a renda. Alguns homens justificaram a violência pelo abuso de álcool da parceira ou de ambos, outros pelo fato de apenas o homem abusar de álcool. Infelizmente, tudo pode ser utilizado como motivo para agredir uma mulher em uma sociedade desigual em relação às questões de gênero: ela ter ou não ter renda, beber ou não beber, etc.

Alguns estudos (Aguiar, 2009; Ravazzola, 1997, 1998) reforçam essa ideia de que homens autores de violência conjugal geralmente utilizam diversas justificativas que favorecem a construção de anestesias e a manutenção da violência. Eles podem sentir-se vítimas do comportamento da mulher; temer a independência de sua ex/parceira; não perceber o sentimento dos outros; sentir que deve controlar a ação da ex/companheira; achar que não necessita de ajuda ou autoconhecimento.

Esse discurso de culpabilização da mulher é reforçado pela desigualdade social entre homens e mulheres na relação conjugal. Essas anestesias dificultam o processo de reflexão dos homens sobre as suas corresponsabilidades na instalação e manutenção da violência. Nesse contexto, os homens não percebem os seus atos como realmente acontecem. A anestesia acontece com tanto êxito em alguns casos que o mal-estar deixa de ser sentido. Essa dinâmica ajuda a entender como muitos homens externalizam a responsabilidade, colocam-se no papel de vítima das agressões, entendem a parceira como objeto e esperam mudanças apenas na mulher ou na relação, mesmo quando a violência é extrema (Angelim, 2009; Guimarães, 2009; Guimarães et al., 2007; IPEA, 2014; Ravazzola, 1997).

Scott (2005) aponta para o perigo da redução de um indivíduo a um objeto, que geralmente ocorre quando homens culpabilizam suas parceiras pela violência sofrida. Ao ser entendida como objeto de discriminação, mulheres podem ser transformadas em estereótipos. Essa discriminação está baseada na desigualdade de gênero, que pode ser devastadora por favorecer o processo de exclusão, patologização e culpabilização da mulher. Geralmente, é construída por meio de justificativas que limitam o papel da mulher exclusivamente na vida privada, sempre vinculado ao cuidado do lar, do companheiro e dos/as filhos/as (Ogando, 2010).

Essa concepção contribui para a instalação da violência na relação, pois quando a mulher descumpre qualquer expectativa social baseada em sua condição feminina, é uma forma de os homens justificarem as agressões e culpabilizarem as mulheres pela violência conjugal. Nessas situações, geralmente há uma inversão da culpabilização devido à desigualdade de poder entre homens e mulheres (Carvalho, 2010; Pratt, 1993). Essa cristalização de homens em papéis de vítimas ou de agressores pode atrapalhar a compreensão e a intervenção em situações de violência conjugal. Essa dicotomia vítima-algoz não leva à transformação (Beiras \& Cantera, 2012; Lima \& 
Büchele, 2011; Medrado, 2009; Medrado \& Méllo, 2008; Toneli et al., 2010). Medrado et al. (2011) reafirmam a necessidade de ampliar a compreensão dos mecanismos que aprisionam os homens para potencializar mudanças subjetivas, relacionais e sociais.

A minimização da violência foi identificada nas respostas dos participantes que banalizavam o impacto da violência. Algumas anestesias descritas pelos homens ilustram essa minimização: "Eu ainda gosto dela"; "Me perdoa, não vai se repetir."; "Não vai acontecer de novo... Eu juro!"; "Eu te amo... Nunca quis magoar você..."; "Ela era tudo pra mim"; "Você precisa me dar mais uma chance... Por favor!"; "Pode ser paciente comigo?”; "Nosso amor não significa nada para você?”; “Não jogue fora nosso amor.”; “Tudo vai mudar, eu juro! Não posso perder você..."; "De achar que está tudo bem, pois a pessoa não dizia que nada a incomodava."; "Sentimento de crer que tudo vai melhorar."; "Ser parceiro e lembrar no dia de amanhã". Algumas narrativas dos participantes exemplificam a minimização da violência:

"Eu achava que ela tinha que me perdoar, porque se a gente errou e gosta, tudo dava um jeito (...) O ser humano é capaz de errar a qualquer momento, mas ele tem que voltar atrás, se arrepender e fazer diferente, senão não adianta a mulher perdoar se o cara continuar do mesmo jeito" P44

“Como é que a gente sabe se a mulher tá gostando? Porque 'amor' é uma palavra muito misteriosa pra mim, eu acho que isso não existe. Se existir, é só amor de mãe e olha lá. De marido e mulher não existe. Eu acho que o cara fala que ama só pra satisfazer a mulher, no fundo não existe nada disso não" P46

As afirmações "Eu ainda gosto dela"; "Eu te amo... Nunca quis magoar você..."; "Ela era tudo pra mim"; "Nosso amor não significa nada para você?”; "Não jogue fora nosso amor.”; "Tudo vai mudar, eu juro! Não posso perder você..." revelam anestesias que indicam o valor de sobrevivência e a dependência afetiva em relação à ex/parceira, que favorecem a sensação de descontrole sobre os seus próprios sentimentos, especialmente por percebê-los como algo externo e incontrolável. Essas crenças favorecem a instalação de dinâmica de submissão e de necessidade do reconhecimento da pessoa amada (Angelim, 2009; Angelim \& Diniz, 2010; Watzlawick et al., 1967/2007). Consideramos que essa manifestação de anestesias é fundamental para uma posterior reflexão com homens que podem ajudá-los a identificar e revisar essas crenças.

A minimização da violência revela também uma expectativa de mudança da mulher ou da relação e uma dificuldade dos participantes em aceitarem o fim da relação. Alguns homens tiveram dificuldade em perceber a gravidade da violência, banalizando as agressões pelo fato de existir afeto ou perspectiva de mudanças. Essa expectativa de manutenção da relação marcada pela violência foi descrita pelos participantes nos seguintes temas: gostar ou amar a parceira, jurar que não vai acontecer de novo, pedir desculpas ou perdão, ela ter que ser paciente com ele, achar que tudo vai melhorar, ser companheiro e preocupar com o futuro. Essas questões reforçam a posição de alguns homens no papel de vítima ou pode contribuir para a ambiguidade de sentimento entre ficar ou não 
na relação. Essas anestesias indicam que para muitos homens, a existência do afeto ou da possibilidade da mudança deveria ter mais peso que a violência.

As anestesias que mostram a dificuldade de alguns homens em aceitar o rompimento da relação somadas às que revelam um grande valor de sobrevivência indicam um alto risco para a escalada da violência. Essas anestesias devem ser identificadas e trabalhadas com muito cuidado. A literatura especializada da área (Ávila et al., 2014; Brasil, 2015; Costa \& Grossi, 2009; Instituto Patrícia Galvão/Data Popular, 2013; Macdonald et al., 2010; Medeiros, 2015; Meneghel \& Hirakata, 2011; Teixeira, 2009; Waiselfisz, 2012; Williams, 2001; Yamamoto \& Colares, 2015) aponta que o momento da separação e da denúncia apresenta maior risco de novas agressões e/ou feminicídio. Nessa situação, podem acontecer as mais temíveis e trágicas consequências da violência, seja no caso de assassinato de mulheres ou de homicídio de mulheres seguido de suicídio do homem. Esse fato revela a importância da ação efetiva do Estado com homens e mulheres em situação de violência conjugal. Essa intervenção deve ser pautada na interdisciplinaridade, de modo a abranger aspectos além da punição, tais como a promoção, prevenção e reorientação dos homens autores da violência (Ávila et al., 2014; Beiras \& Cantera, 2012; Porto \& Costa, 2010; Silveira et al., 2009).

A terceira categoria de anestesias criada refere-se à negação da violência. Essa negação foi identificada nas seguintes respostas dos participantes da segunda etapa: "Ela não precisava chamar a polícia"; "Eu não vou perder minha família"; "Ela é muito sensível”; "Não desista de nós logo agora, meu amor..."; "Não acredito que magoei você desse jeito..."; "Mas ela é minha mulher"; "Quero que nós dois viremos um só..." e "Eu fiz mesmo essas coisas? Não me lembro...”; "Eu não fiz nada"; "Eu nada faço"; "Sentimento de revolta”. As anestesias mostram como muitos homens negam a violência ao perceber sua ex/parceiras e suas famílias como seus objetos, como suas propriedades; ao considerar que as mulheres são sensíveis por perceberem agressões onde não existiria; entender que elas estão desistindo do amor por nada; não acreditar que magoaram as mulheres; compreender que eles têm o direito de controlá-las ao ponto de serem uma só pessoa; por não lembrar de ter ocorrido agressão; ou, simplesmente, por considerar que não fizeram nada e ficarem revoltados por estarem na Justiça.

Essas anestesias ilustram bem o impacto da construção da masculinidade hegemônica, que tende a fomentar a ideia de posse sobre a mulher, o que para muitos é entendido como uma atribuição de direito ao uso da força como forma de imposição de seus desejos e de dominação sobre seu corpo, sexualidade, vontades. A narrativa de um participante exemplifica bem a dificuldade de perceber a violência na relação:

“Marquei essa aqui: 'ela é sensível demais', 'não desista de nós logo agora, meu amor' e 'me perdoa, não vai se repetir' [...] Na minha história tem a ver porque eu 
aprontava mesmo, saia todo final de semana quando não tava trabalhando, ganhava o mundo e pegava geral, dai a gente brigava muito, e eu achava que ela tinha que perdoar, coisa de homem machista né. Depois que começou esse negócio aqui [grupo] vi que errei e coloquei a cabeça no lugar e ficou mais tranquilo. Eu ainda acho que ela é sensível, mas eu ajudava no ciúmes dela, ela estressava mais ainda e ai era briga mesmo (...) Eu achava que homem podia, com as conversas aqui vi que é ruim né, a gente se coloca no lugar dela" P31

Alguns homens manifestaram uma compreensão enviesada e arraigada da mulher como sendo sua posse. Essa visão estereotipada da ex/parceria lhe "dá o direito" de controlá-la e agredila. Essas crenças geralmente têm como referencial de base os padrões de masculinidade hegemônica (Almeida, 1995; Connell, 1997; Separavich \& Canesqui, 2013; Silveira et al., 2009; Teixeira, 2009). O processo de socialização tem grande peso na naturalização da violência por parte dos homens. Essa banalização exerce forte estímulo e legitima o uso da força física como forma de restaurar o poder e resolução dos conflitos (Maciel \& Barbosa, 2010).

O título desse trabalho foi baseado em uma dessas respostas que indicam negação do homem: "Ela não precisava chamar a polícia", por ser a anestesia que os próprios participantes escolheram como a mais importante - conforme a Tabela 6.9A. Essa compreensão dificulta a percepção da violência e facilita o processo de naturalização das agressões no espaço privado, pois contribui também para que homens considerem desnecessária a busca da Justiça ou de terceiros por parte da mulher. Muitos homens percebem a denúncia das mulheres como algo desnecessário por considerarem que não houve violência. Geralmente, eles não conseguem reconhecer a violência sofrida pelas ex/companheiras e não compreendem a denúncia como um meio para elas buscarem e receberem apoio e proteção (Maciel \& Barbosa, 2010; Silveira et al., 2009).

A polarização entre o público e privado favorece a ampliação dessa negação da violência conjugal por parte dos homens. A desigualdade de valores entre a esfera pública - entendida como a mais importante - e a esfera privada compreendida como de menor valia reforça essa polarização. Os fatos que acontecem no âmbito doméstico são vistos como de menor importância (minimização) ou nem são percebidos (negação), inclusive a violência (Maciel \& Barbosa, 2010; Silveira et al., 2009).

Ravazzola (1997) entende que esse processo de negação só é possível pelo fato de que as pessoas envolvidas "não veem que não veem” as agressões. Os homens podem seguir uma lógica de naturalização da violência na qual não percebem as agressões como algo nocivo para a mulher e nem para si. Assim, não conseguem ter consciência do significado da violência e de suas consequências. Daí a concepção de uma verdadeira anestesia ou “duplo-cego” (Ravazzola, 1997).

Ponce-Antezana (2012) corrobora essa ideia e reforça que o reconhecimento da violência é difícil para muitos homens autores de violência. Em muitos casos, o sentido da violência não é 
sequer percebido por eles: "sem ser compreendido, narrado e nem nomeado e, portanto, as possibilidades de uma apropriação real de si mesmo para efetivamente assumir responsabilidades torna-se impossível, de maneira que a vivência fica uma vez mais localizada fora deles e das suas narrativas" (p. 18).

O início do processo de reconhecimento da violência foi identificado nas respostas de muitos participantes: "O que me impedia era a vergonha de pedir ajuda pra alguém”; "Conversas"; "Paciência"; "Humildade"; "Ela me ama até hoje e eu também, mas só vamos retornar depois do tratamento, começamos a fazer tratamento e me sinto mudando muito”; "Pensamento de ter morte ou ter violência grave”; "Sentimento de incapacidade". Algumas narrativas ilustram esse início de reconhecimento da violência em suas relações:

'Eu marquei essa 'tudo vai mudar, eu juro', porque eu tenho que mudar, porque se não mudar acaba tudo, não quero voltar pra cá [Justiça]. Só que antes eu falava que ia mudar e não mudava nada, era da boca pra fora" P29

“Eu coloquei aqui 'a gente bebia muito' e 'ela não precisava chamar a polícia', eu sempre achei que ela era exagerada e que não precisava tá aqui [na justiça]. Agora eu to vendo que se ela não chamasse a polícia a gente ia matar o outro, que eu ia morrer de cachaça ou ia matar ela, eu só parei de beber porque to aqui. Foi até bom pra mim, porque senão eu num tinha me recuperado do alcoolismo e dos negócios que eu tava fazendo errado com ela. Eu coloquei 'não vou perder minha família' porque eu tava errado e tinha que mudar mesmo pra não ficar sem ela" P36

"As minhas foram 'eu ainda gosto dela, me perdoa não vai se repetir e nunca quis magoar' (...) Eu ainda gosto dela mesmo, a gente voltou na sexta, depois de quase um ano separado, depois de um tempo bom né (...) Só que agora a gente conversou muito, antes eu falava pra ela que não ia fazer de novo e no outro dia já tinha confusão. A gente conversou pra não ter problema de novo, passou o dia todinho acertando as coisas (...) a gente tem que assumir o erro e corrigir (...) tudo que eu to aprendendo aqui, eu to passando pra ela" P52

Alguns homens manifestaram que poderiam estar errados, ter alguma culpa ou problema inclusive com álcool ou ciúmes e que tiveram dificuldade em pedir ajuda. Outros participantes descreveram alguns sentimentos que podem contribuir para a percepção da violência: vergonha, arrependimento e impotência. Muitos deles apresentaram também o intuito de adotar algumas estratégias, tais como ter mais diálogo, paciência, humildade. Um participante percebeu que apesar de existir amor na relação, esse sentimento não é suficiente para evitar a violência e que precisam buscar ajuda profissional para evitar a reinstalação das agressões na conjugalidade. Outro homem percebeu o alto risco da relação ter novas agressões mais graves ou ter um desfecho trágico pela morte, provavelmente da mulher por ser a pessoa em maior situação de vulnerabilidade.

Essa percepção mais realista da relação é importante, pois a idealização da relação é uma forma muito comum para homens autores justificarem a violência e culpabilizarem as ex/parceiras pelas agressões (Silveira et al., 2009). Esse processo de reconhecimento pode ajudar esses homens a 
revisar, desafiar e refletir sobre suas ideias, sentimentos e ações que favorecem a perpetuação da violência, especialmente a negação, minimização e a desresponsabilização das agressões. A estratégia utilizada auxiliou alguns participantes a reavaliarem algumas questões pessoais, de sua dinâmica relacional, assim como alguns aspectos do contexto social que sustentam a violência conjugal na relação (Ravazzola, 1997). Esse processo pode ter ajudado na identificação de anestesias relacionais que os impedem de sair do relacionamento ou mesmo superar a violência permanecendo na relação, quando não desejam o rompimento do vínculo.

Não se pode ter uma visão simplista e enxergar a violência como sendo necessariamente intrínseca ao individuo. A socialização de gênero influencia diretamente na forma com que os homens naturalizam a violência. O reconhecimento dessas questões sociais por meio das anestesias é um primeiro passo para ajudar as pessoas a superar esse padrão de socialização que aprisiona e traz tantas consequências deletérias para homens e mulheres (Nascimento et al., 2009; PonceAntezana, 2012; Separavich \& Canesqui, 2013; Teixeira, 2009).

O processo de construção de anestesias ocorre de forma sistêmica, com influência de questões sociais e culturais sobre a dinâmica familiar e conjugal. A sua ressignificação também é complexa e exige recursos criativos e diferenciados para intervir com os homens autores. A estratégia metodológica proposta nesse estudo pretende ser mais uma opção para ampliar os recursos para identificar anestesias desses homens. Ressaltamos que pode ser uma estratégia dentro de um contexto de intervenção mais amplo, pois não deve ter o objetivo de identificar e de lidar com todas as questões da violência em um único atendimento, nem de que esses homens conseguiriam manifestar todas anestesias, o intuito foi iniciar esse processo de manifestação de alguns indícios de negação, minimização e desresponsabilização da violência.

O diferencial dessa pesquisa é apresentar uma estratégia que tem o potencial de favorecer a manifestação, identificação, nomeação e reflexão sobre as anestesias por parte dos próprios homens autores e não apenas pelo profissional. Esse processo de reflexão ocorreu gradualmente em várias etapas. Iniciou-se com a leitura das anestesias nomeadas pelos estímulos - seja da autora/personagem na primeira etapa ou de outros homens autores na segunda; continuou-se com a escolha das anestesias presentes nas histórias dos homens dentre as anestesias apresentadas pelos estímulos; depois os homens selecionaram as três anestesias que consideraram mais influentes em suas vivências; só então eles acrescentam as anestesias advindas de sua experiência e que não estavam listadas no estímulo fornecido.

Essa aproximação gradativa ajuda o participante a ir reconhecendo e lidando com seus sentimentos - dor, medo, vergonha, revolta, ansiedade, angustia, tristeza, perda. Tal fato, aliado à identificação com o personagem e com os/as outros/as participantes do Grupo Misto do SERAV e 
do Grupo de Homens do NAFAVD cria um contexto propício à nomeação e ruptura do pacto de silêncio, autoexpiação, minimização e negação da violência.

Essa estratégia pode, então, ir muito além da responsabilização. A busca por objetivos que transcendem a responsabilização não significa banalização da violência. É preciso acreditar e insistir na capacidade de mudança, transformação e reelaboração de significados de masculinidades e de violências pelos homens. Essa capacidade pode ser buscada mesmo em acompanhamentos psicossociais no contexto da Justiça, que tem o potencial de obter mudanças subjetivas de homens. Dessa forma, os grupos de reflexão podem configurar como verdadeiros instrumentos para mudança, especialmente nas intervenções que considerem direitos humanos e a prática cidadã para superação da violência conjugal (Fávero, 2010; Maciel \& Barbosa, 2010; Manita, 2008).

Essas intervenções têm maior potencial de considerar as diversidades dos indivíduos, das masculinidades e a variabilidade das conjugalidades. Entendemos que essa forma de intervenção indireta por meio do estímulo do livro facilita a escuta desses homens como seres humanos e a percepção de suas necessidades. Ela também busca a responsabilização do ato agressivo, a eleição da violência pelos homens e uma posterior possibilidade de superação da violência e de mudança das masculinidades e conjugalidades (Beiras \& Cantera, 2012; Separavich \& Canesqui, 2013).

Entendemos que é imprescindível ajudar esses homens a nomearem a suas anestesias, para que, posteriormente, eles mesmos consigam iniciar o processo de ressignificação de anestesias em sua relação conjugal. Essa pesquisa inclui esse entendimento e leva em consideração que esses homens podem estar aprisionados a padrões relacionais contraditórios e com grande investimento afetivo (Angelim, 2009; Angelim \& Diniz, 2010). Por isso, a reflexão sobre os duplo-vínculos pode complementar esse processo de conscientização das anestesias relacionais (Ravazzola, 1997, 1998).

\section{Duplo-vínculos e nomeação da violência conjugal pelos homens autores}

As duas últimas perguntas do questionário tiveram como objetivo conhecer como os participantes nomearam e perceberam a própria história tendo como estímulo inicial o título do livro "Mas ele diz que me ama". As Tabelas 6.16 e 6.16A resumem as respostas de nomeação da própria vivência conjugal pelos homens da primeira e da segunda etapa da pesquisa, respectivamente.

As perguntas seis e sete do questionário da segunda etapa foram construídas a partir das nomeações da própria vivência pelos participantes da primeira etapa. Nesse contexto, apresentaremos inicialmente os resultados dessa etapa e, em seguida, da segunda.

$\mathrm{Na}$ Tabela 6.16, a primeira coluna da tabela apresenta o número indicativo de cada participante. A segunda coluna mostra a resposta ao item sete do questionário. Esse item solicitou aos homens nomearem a sua vivência com a seguinte instrução: “A Roz resumiu a história dela com o título: 'Mas ele diz que me ama...'. Qual seria o título da sua história?’. As respostas ao 
item oito do instrumento estão descritas na terceira coluna da tabela, cujo comando foi: "Inspirado em sua história, complete a frase/título do livro: "Mas ele diz que me ama...". A organização em única tabela permite a análise conjunta da resposta de um mesmo participante às perguntas sete e oito do questionário.

Tabela 6.16

Título e Nomeação das Próprias Histórias pelos Participantes da $1^{a}$ Etapa

\begin{tabular}{lll}
\hline & Título & $\begin{array}{l}\text { Complemento da frase } \\
\text { "Mas ele diz que me ama..." }\end{array}$ \\
\hline 1. & Ela diz que não me ama mais & $\begin{array}{l}\text { Quem ama não faz o que ele fazia, ele era um } \\
\text { monstro para ela!!! }\end{array}$ \\
2. & Ela ama e seria apta a perdoar & $\begin{array}{l}\text { Porém tem que ter uma verdade certa } \\
\text { A vida e as surpresas }\end{array}$ \\
3. & A ingratidão & Por que fiz isso? \\
4. & Mas ela é religiosa & Mas era só ilusão \\
5. & Quem ama não bate & Mas envergonha \\
6. & A culpa é só minha & Mas ela diz que me ama \\
7. & Será que ela me ama & - \\
8. & Ela me ama & Mas não agi com amor \\
9. & Fui amado, mas não soube amar & Mas suas atitudes provam o contrário \\
10. & Mas eu não posso abandonar os meus filhos & Mas ninguém prometeu de amar ninguém \\
11. & Vacilão & Mas tudo pode mudar... \\
12. & Até que as coisas começam a mudar... & Mas porém a pessoa que ama não trai, bate, \\
13. & Será que o erro está em mim? & não menti. \\
\hline
\end{tabular}

A nomeação/intitulação da própria história pelos homens da primeira etapa revelou alguns indícios de paradoxos da presença da violência em suas vivências conjugais. Os participantes descreverem aspectos nesse sentido: ter sido iludido, esperar o perdão da parceria, ter deparado com a ingratidão da mulher, perceber sua culpa, ter vacilado, questionar o seu próprio erro, sentir vergonha, esperar mudanças e, especialmente, relacionado ao afeto - de ser amado e esse afeto justificar a violência.

Sete dos 13 participantes da primeira etapa trouxeram referências diretas ao sentimento de “amor" em seus títulos. Essa associação entre a coexistência do amor e da violência pode revelar a presença de mensagens paradoxais exercidas por pessoas de grande valor afetivo, que dificultam a reflexão sobre a relação conjugal estruturada pela violência (Angelim, 2009; Angelim \& Diniz, 2010). As respostas dos homens trouxeram indícios de relacionamentos marcados pelo valor de sobrevivência (Angelim, 2009; Angelim \& Diniz, 2010). A percepção de o relacionamento ser marcado por esse imenso valor afetivo é reforçada pela citação da palavra "amor" de suas respostas.

A partir desses títulos apresentados pelos próprios homens na primeira etapa, em reunião de equipe de orientação do doutorado, nós elaboramos as perguntas seis e sete do questionário da segunda etapa. O intuito foi construí-las a partir de nomeações que resumissem bem os títulos dos participantes da primeira etapa. 
Escolhemos o título do Participante 13 para servir como estímulo para a questão sete da segunda etapa. Essa escolha se deu por dois motivos: por entendermos que esse seja um dos casos mais graves dentre os 13 participantes dessa etapa e por sua resposta ter o potencial de estimular o reconhecimento de responsabilidade dos homens - especialmente pelo questionamento de possível “erro" do participante. Assim, essa questão ficou da seguinte forma para a segunda etapa: "Um homem resumiu a história dele com a frase: ‘Será que o erro está em mim?' Qual é o título da sua história?".

Para a questão oito, escolhemos dois títulos que poderiam representar o paradoxo entre a palavra "amor" e a violência, pois a maioria dos participantes dessa etapa relacionou o fato de amar/ser amado e a existência desse afeto justificar a violência conjugal. Assim, a questão oito foi formulada da seguinte maneira: "Inspirado em sua história, complete as frases abaixo: 'Quem ama não bate, mas...' e 'Fui amado, mas...".

A partir dessas perguntas, os participantes da segunda etapa puderam ter estímulos para intitularem/nomearem suas próprias histórias. Essas perguntas foram criadas de acordo com os objetivos da pesquisa, no intuito de verificar como os homens da segunda etapa manifestariam os títulos de suas vivências conjugais e se essa nomeação da relação poderia ter indícios de critérios de duplo-vínculos da dinâmica. Após a contextualização do procedimento de construção desse questionário, podemos discutir as respostas apresentadas pelos participantes da segunda etapa da pesquisa.

Na Tabela 6.16A, a primeira coluna da tabela apresenta o número indicativo de cada participante da segunda etapa. A segunda coluna mostra a resposta ao item sete do questionário. Esse item solicitou aos homens nomearem a sua vivência com a seguinte instrução: Um homem resumiu a história dele com a frase: "Será que o erro está em mim?" Qual é o título da sua história?. As respostas ao item oito do instrumento estão descritas na terceira e quarta colunas da tabela, cujo comando foi: Inspirado em sua história, complete as frases abaixo: “Quem ama não bate, mas..." e "Fui amado, mas... A organização em única tabela permite a análise conjunta das respostas de um mesmo participante às perguntas sete e oito do questionário. Esse formato possibilita a compreensão mais clara de alguns critérios de duplo-vínculo.

A análise dessas respostas em conjunto foi feita com base no entendimento que a resposta à questão sete do instrumento pode possibilitar aos participantes exporem as anestesias que os aprisionavam ou os aprisionam à relação conjugal. As respostas ao item oito pode permitir a constatação de que há algo errado no relacionamento: estimulados pela inserção da palavra "mas" dos títulos escolhidos da primeira etapa. Ao juntar as três respostas, imaginamos ser possível fazer uma reflexão sobre os títulos das vivências conjugais desses homens e verificar se essa nomeação 
da relação poderia ter indícios de critérios de duplo-vínculos da dinâmica. Esperamos que surgissem alguns paradoxos entre as anestesias apresentadas pelos homens e a percepção da realidade da violência em suas conjugalidades. Essa análise das respostas de cada participante pode auxiliar no entendimento de algumas características duplo-vinculares de dinâmicas conjugais marcadas pela violência conjugal a partir da perspectiva de homens autores de violência.

Tabela 6.16A

Título e Nomeação das Próprias Histórias pelos Participantes da $2^{a}$ Etapa

\begin{tabular}{|c|c|c|c|}
\hline & Título & $\begin{array}{l}\text { Complemento da frase 1: } \\
\text { "Quem ama não bate, mas... }\end{array}$ & $\begin{array}{l}\text { Complemento da frase } 2 \\
\text { "Fui amado, mas... }\end{array}$ \\
\hline 14. & Sou mesmo o errado? & Ao bater arca com as consequências... & Fui encarcerado! \\
\hline 15. & O erro está em mim & Cuida & Ai não duvidar \\
\hline 16. & O erro foi dela, sempre ela errou. & Depende da raiva. & Não fui amado. \\
\hline 17. & "Amor imaturo" & Cuida e dar carinho & Não deu certo \\
\hline 18. & Falta entendimento pros dois & Não apanha. & Ela tem força na língua \\
\hline 19. & Não quero culpar ninguém & Cuida & - \\
\hline 20. & $\begin{array}{l}\text { "Não precisava ter chegado a esse } \\
\text { ponto." }\end{array}$ & $\begin{array}{l}\text { Na hora da raiva e das humilhações a gente } \\
\text { perde a cabeça }\end{array}$ & $\begin{array}{l}\text { Por um motivo banal, besta gerou } \\
\text { uma confusão, que chegou à polícia. }\end{array}$ \\
\hline 21. & "Nossa história: nota 7" & Magoa & Não amei. \\
\hline 22. & $\begin{array}{l}\text { "Tive falhas, mas não era pra ter } \\
\text { ocorrido isso" }\end{array}$ & Maltrata. & Não deu certo \\
\hline 23. & A gente cansa. & Sofro muito. & - \\
\hline 24. & A minha mulher é muito ciumenta & Jamais eu lhe trisco & - \\
\hline 25. & Tapas e beijos & - & - \\
\hline 26. & $\mathrm{O}$ erro foi dos dois & Cuida & - \\
\hline 27. & Eu achei que Ela me amava. & Cuida e valoriza. & Também enganado. \\
\hline 28. & O erro dos dois & Fazer o que? & Não fui. \\
\hline 29. & Será que o erro está em mim & Quem apanha não esquece & Nunca esqueci \\
\hline 30. & Pra que tanto ciúmes & Cuida & Não correspondido \\
\hline 31. & $\begin{array}{l}\text { Por que de tantas arrogâncias (minha e } \\
\text { dela) }\end{array}$ & Cuida & Agora odiado \\
\hline 32. & O erro foi eu & Perdoa e não trai & Não dei valor \\
\hline 33. & Ainda vamos ser muito feliz. & Sim, dá amor e carinho & Amei muito também \\
\hline 34. & O erro foi meu & "educa" & Ainda sou amado \\
\hline 35. & - & Cuida & Eu não amava \\
\hline 36. & Eu estava errado & Ama & Não fui amado \\
\hline 37. & Ela tem que ser mais calma & Compreende & Amei também e amo \\
\hline 38. & O erro era nos dois & Ama & Não sou mais \\
\hline 39. & O erro está em nós & Sim procura resolver o problema & Não dei valor, mas nunca é tarde \\
\hline 40. & "O erro sempre foi de nós dois."” & Dá carinho & Ainda amo ela. \\
\hline 41. & A gente tem uma convivência boa & Arrepende depois & Fui correspondido \\
\hline 42. & "O machista" & Quem bate se arrepende depois & Não dei valor \\
\hline 43. & O ciúme recíproco traz problemas & Quando se trata de ciúme doentio... & $\begin{array}{l}\text { Ela era violenta e pirracenta... e } \\
\text { braba... }\end{array}$ \\
\hline 44. & Foi após a separação & Só com a ira & Mas ela esqueceu da família \\
\hline 45. & A falta de diálogo & Demonstra & Eu não amei \\
\hline 46. & As influências atrapalham & Então me respeita & Eu não dei valor \\
\hline 47. & Ela foi difícil de relacionar & Fala sério & Não fui correspondido \\
\hline 48. & Os erros que não percebi & Magoa sem perceber & Cometi erros \\
\hline 49. & "Não vou levar desaforo para a casa" & Leva pancada. & Fui desprezado. \\
\hline 50. & Sem noção & Saí fora & Aproveitado \\
\hline 51. & Incapacitado & Perdoa & Não realizado \\
\hline 52. & Será que eu sou o errado & Dá carinho, amor, respeito etc; & Não dei valor \\
\hline 53. & Será que a mulher está sempre certa? & Compreende o parceiro & Não estava preparado \\
\hline 54. & $\begin{array}{l}\text { Uma família é feliz quando sabe } \\
\text { conversar }\end{array}$ & Quem não escuta pode agredir & Não fui ouvido \\
\hline 55. & O erro foi bebida ou foi eu mesmo & Dá carinho e amor & Não correspondi do jeito certo \\
\hline 56. & Tudo novo de novo & Respeita & $\mathrm{O}$ ciúmes dela era maior \\
\hline 57. & Julgamos o livro pela capa & Evita a discussão & Não compreendido \\
\hline 58. & $\begin{array}{l}\text { Uma história de amor, ao mesmo } \\
\text { tempo de terror }\end{array}$ & Cuida & Ao mesmo tempo desamado \\
\hline
\end{tabular}

As respostas/percepções dos homens da primeira e da segunda etapas acerca de suas histórias foram analisadas à luz da Teoria do Duplo-Vínculo - TDV. Vários estudos (Hamilton \& Armstrong, 2009; Mahmoud, 2003) defendem a importância de se discutir a dinâmica duplo- 
vincular para ampliar a compreensão das relações sociais, familiares e conjugais, mas poucos estudos relacionam TDV e violência conjugal (Angelim, 2009; Angelim \& Diniz, 2010; Knickmeyer et al., 2003).

Watzlawick et al. (1967/2007) afirmam que o padrão de duplo-vínculo aprisiona todas as pessoas envolvidas na trama relacional. A dinâmica também gera um duplo-vínculo para quem o estabeleceu. Essa pesquisa pretende ser mais um pequeno passo para ampliar essa área de conhecimento. Esperamos ajudar na compreensão de como os homens autores também podem ficar presos a essa dinâmica. Essa compreensão pode ser importante para embasar estudos futuros que busquem formas de auxiliá-los a refletir e a superar os critérios duplo-vinculares presentes em muitas relações conjugais marcadas pela violência conjugal.

A nomeação/intitulação da própria história pelos homens revelou alguns paradoxos da presença da violência na relação de muitos participantes. A partir da análise dos títulos foram identificadas quatro categorias de paradoxos entre o discurso de naturalização da violência e a presença de agressões na relação: desresponsabilização dos homens; minimização; negação; início do processo de reconhecimento da violência. Essas categorias são apresentadas e problematizadas a seguir.

Alguns homens trouxeram respostas que ajudam a compreender os paradoxos entre o discurso de desresponsabilização dos homens e a manutenção de violência conjugal na relação. Esses paradoxos são expostos nas seguintes respostas que indicam a externalização da responsabilidade dos homens da segunda etapa: "O erro foi dela, sempre ela errou; Depende da raiva; Não fui amado.”; "Falta entendimento pros dois; Não apanha; Ela tem força na língua”; "A gente cansa; Sofro muito.”; "Eu achei que Ela me amava.; Cuida e valoriza.; Também enganado.”; "Será que o erro está em mim; Quem apanha não esquece; Nunca esqueci"; "Pra que tanto ciúmes; Cuida; Não correspondido"; "O erro foi meu; educa; Ainda sou amado"; "Ela tem que ser mais calma; Compreende; Amei também e amo"; "O ciúme recíproco traz problemas; Quando se trata de ciúme doentio...; Ela era violenta e pirracenta... e braba..."; "Foi após a separação; Só com a ira; Mas ela esqueceu da família”; “As influências atrapalham; Então me respeita; Eu não dei valor"; "Ela foi difícil de relacionar; Fala sério; Não fui correspondido"; "Não vou levar desaforo para a casa; Leva pancada.; Fui desprezado.”; "Sem noção; Saí fora; Aproveitado"; "Será que a mulher está sempre certa?; Compreende o parceiro; Não estava preparado"; "O erro foi bebida ou foi eu mesmo; Dá carinho e amor; Não correspondi do jeito certo"; "Tudo novo de novo; Respeita; O ciúmes dela era maior"; "Julgamos o livro pela capa; Evita a discussão; Não compreendido". Algumas narrativas dos participantes durante a reflexão grupal ilustram bem essa desresponsabilização da violência: 
"Quando o juiz manda a gente pra cá, tem que mandar a mulher também, porque o erro é dos dois, os dois têm que mudar ou pros dois separar se não der certo" P26

"Eu coloquei 'quem apanha não esquece' porque eu apanhei e o errado foi eu, sobrou pra mim ainda" P29

"Eu achava que homem podia educar a mulher mesmo, agora to vendo que tava errado, o erro foi meu mesmo" P34

"Eu coloquei que foi depois da separação, porque a gente brigava por causa do filho, não melhorou nada porque eu queria que ela fizesse tudo do meu jeito assim mesmo. Ela tava com enxaqueca, daí eu falei pra ela ir no hospital e ela não queria ir, então eu peguei ela no braço pra ela ir" P44

“A mulher me perguntava: 'você me ama?' Eu falo pra ela, 'to me acostumando com tu, minha filha?' Eu já levei porrada demais, pancada demais, por isso escrevi que fui desprezado. Eu tenho só respeito, mas amar mesmo, eu não amo mais não, confio mais não (...) Eu gostei, amei mesmo, mas sabe o que acaba com o amor? Vem umas palavras que acaba com a gente. Eu falava pra umas das mulheres que eu tive 'dá um tapa na cara, mas num fala uma palavra pra marcar o meu coração não', isso marca o coração, isso que acaba com o amor, o cara vai desgostando, a mulher vai desgostando, a gente também fala essas coisas. As vezes é melhor levar uma porrada do que ficar guardando aquilo dentro da gente, tem umas mulher que tem fogo na língua" $\mathrm{P} 49$

"Eu botei aqui: fui amado, mas ela era violenta, pirracenta e braba... Só que eu também sou assim, sou violento e brabo, só não sou pirracento. (...) No título coloquei sobre o ciúme nosso, porque eu achava que era dono dela, tinha ciúmes e não controlava mesmo, ela também era assim. Os dois tem que saber se controlar. Eu sou comerciante, eu tenho que lidar com o público, eu trato as pessoas fora bem, todo mundo bem. Antes ela morria de ciúme porque eu tratava as clientes bem, mas era o meu ganha pão. Hoje eu to controlando e ela também. Se eu dou conta de tratar os clientes bem, eu tenho que tratar ela bem também" P43

"Por isso eu coloquei que 'as influências atrapalham', sempre tem alguém querendo intrometer, eu não aceito.” P46

As respostas desses participantes indicam que eles percebiam ou percebem a violência como algo que estava totalmente fora de sua responsabilidade, especialmente por jogar a culpa nas mulheres, ciúmes ou bebida. Muitas dessas justificativas são amparadas por diversos mitos e estereótipos legitimados socialmente e que contribuem para naturalizar a culpabilização das mulheres e desresponsabilização dos homens.

Esses mitos que culpabilizam a mulher e desresponsabilizam os homens são complementares e contribuem de forma significativa para justificar a violência. Ao mesmo tempo em que existe a tendência em culpabilizar e psicopatologizar as mulheres, os homens autores de violência também são desresponsabilizados pelas agressões. A presença desses mitos sociais favorece a perpetuação desses paradoxos que estruturam a relação e têm grande impacto em todas as pessoas envolvidas nas relações marcadas pela violência conjugal. Esses mitos atuam como referências, mas não são totalmente impositivos ou determinantes. Eles agem como mapas que orientam e combinam as prescrições sociais com as relações concretas com outras pessoas. Nesse 
contexto, as pessoas atualizam as questões sociais nos âmbitos afetivo, interacional e familiar (Diniz \& Angelim, 2003; Gregori, 1993; Medrado et al., 2011).

Brah (2006) afirma que culpabilização da mulher pela violência sofrida revela a desigualdade entre homens e mulheres. As diferenças entre os dois sexos sempre existiram e sempre existirão. O problema surge quando essas diferenças se transformam em desigualdades na sociedade e nas relações familiares e conjugais. Carvalho (2010) reforça essa ideia por afirmar que existe uma conversão das diferenças em desigualdades ontológicas quando as mulheres são julgadas como inferiores, naturais e imutáveis. Essas condições implicam na maneira como os homens autores de violência justificam a necessidade do controle masculino sobre as mulheres.

A segunda categoria referiu se ao paradoxo entre violência e a sua minimização, especialmente por meio da vivência de ambiguidade de sentimentos sobre a relação conjugal. Essa ambiguidade foi revelada nas respostas de diversos participantes da segunda etapa: "Nossa história: nota 7; Magoa; Não amei."; "Tapas e beijos"; "O erro foi dos dois; Cuida”; "O erro dos dois; Fazer o que?; Não fui”; “O erro era nos dois; Ama; Não sou mais”; “O erro sempre foi de nós dois; Dá carinho; Ainda amo ela."; "Uma história de amor, ao mesmo tempo de terror; Cuida; Ao mesmo tempo desamado". Muitos homens percebem o fato de o erro estar nos dois como algo que minimiza suas agressões.

A expectativa de conformidade das mulheres e a compreensão de que o erro também é da parceira pode favorecer a minimização da violência e dificultar a percepção pelos homens de várias mensagens paradoxais nas conjugalidades marcadas pela violência (Angelim, 2009; Angelim \& Diniz, 2009; Mahmoud, 2003; Watzlawick et al., 1967/2007). É fundamental, então, a reflexão a respeito das respostas que indicam os paradoxos entre essas expectativas dos homens sobre o conformismo das mulheres à dinâmica marcada pela violência. O estímulo da capacidade de revisão desses paradoxos pode ajudá-los a verificar os benefícios da igualdade de direitos e de possibilidades na relação conjugal. Essa igualdade não significa a ausência ou eliminação da diferença entre homens e mulheres, mas o reconhecimento das diferenças. Dessa forma, os homens podem compreender cada vez mais quando a diferença resulta diretamente em desigualdade, exploração e opressão. Podem perceber, também, quando essa diferença pode significar relações marcadas pelo igualitarismo, pela diversidade e por formas mais democráticas de se relacionar (Brah, 2006; Scott, 1995, 2005).

Temos que percorrer um longo caminho até conseguir o reconhecimento social das vantagens da igualdade de direitos entre homens e mulheres, inclusive nas relações conjugais. Essa reflexão pode ser útil em ações preventivas e interventivas - inclusive nos grupos de homens autores de violência. A revisão sobre esses paradoxos pode ter contribuído para reflexão e 
sensibilização dos seis participantes da primeira etapa que citaram essas respostas. Todos eles aceitaram encaminhamento ao final do acompanhamento psicossocial no Grupo Misto. Essa proposta de intervenção grupal com homens pode contribuir como um passo pequeno, mas importante rumo a uma sociedade mais igualitária e sem tanta violência conjugal.

Muitos participantes da segunda etapa ao responderem a questão oito do questionário revelam paradoxo das relações ao completarem as frases: "Quem ama não bate, mas..." e "Fui amado, mas...”. Esses paradoxos foram expressos nas seguintes respostas: "Cuida; Ai não duvidar"; "Cuida e dar carinho; Não deu certo"; "Magoa; Não amei”; "Maltrata; Não deu certo"; "Cuida e valoriza; Também enganado"; "Cuida; Agora odiado"; “Ama; Não fui amado"; "Ama; não sou mais"; "Demonstra; Não sou mais"; "Demonstra; Eu não amei”; "Então me respeita; Eu não dei valor"; "Dá carinho e amor; Não correspondi do jeito certo". As respostas de 12 participantes revelaram paradoxos entre cuidar/ser cuidado, dar carinho, valorizar/ser valorizado, amar, demonstrar afeto, ser respeitado em contraste com a relação não ter dado certo, existir desconfiança e dúvidas, mágoa, não amar, maltrato, ser enganado, não correspondido, ódio, não ser amado, não dar valor e não ser correspondido. Ou seja, evidenciaram a ambiguidade de sentimento entre a expectativa do afeto e a constatação da violência ou que algo não está bem na relação.

Toneli et al.(2010) ajuda a compreender como a ambiguidade dessas respostas podem ser prejudiciais aos homens e às mulheres envolvidos/as em violência conjugal. Esse tipo de violência geralmente é vivenciado entre pessoas que têm grande valor afetivo e lugar de referência entre si. Dessa forma, essa relação pode misturar diversos sentimentos contraditórios. A vivência de ambiguidade de afeto, inclusive de amor e ódio em relação ao/à parceiro/a, é tão significativa que pode afetar diretamente a qualidade do relacionamento conjugal e a construção da própria identidade das pessoas envolvidas (Fávero, 2010; McGoldrick, 1994; Vazquez, 2014).

As respostas dos participantes evidenciaram o paradoxo entre a dúvida do afeto da ex/parceira e a constatação de que algo vai mal na relação, de que a mulher não lhe ama mais e/ou que ele pode ter errado com a mesma, inclusive de ter agredido a ex/parceira. A coexistência da confiança (ou a constatação de sua falta) aliada ao sentimento de insegurança diante dessa dúvida do afeto da ex/companheira também pode favorecer a intensificação do primeiro critério de duplovínculo - o valor de sobrevivência em relação ao cônjuge, pois aumenta a vulnerabilidade dos homens ao paradoxo entre amor e violência (Angelim, 2009; Angelim \& Diniz, 2010). Watzlawick et al. (1967/2007) afirmam que esse dilema seria impossível se não houvesse confiança em algum momento.

Os indícios de um relacionamento marcado pelo alto valor de sobrevivência podem ser identificados nas justificativas que os homens apresentam para a manutenção da relação conjugal 
(Angelim, 2009; Angelim \& Diniz, 2010; Watzlawick et al., 1967/2007). O relato de afeto pela ex/parceira pode significar o desejo de manter o controle sobre a mesma, inclusive após o término da relação nos casos em que há separação. Esses indícios podem revelar e potencializar a vulnerabilidade dos homens à violência conjugal (Silva \& Sattler, 2015; Teixeira, 2009).

Esses aspectos paradoxais presentes nos discursos de homens também podem evidenciar possibilidades de mudanças pessoais e/ou relacionais (Silveira et al., 2009). Esses pesquisadores ressaltam que as mensagens marcadas pela ambiguidade de sentimentos não possuem apenas aspectos negativos.

Silveira et al. (2009) afirmam que essa ambiguidade pode ser um fator propulsor e potencializador de mudanças na resolução dos conflitos e de transformações na relação conjugal marcada pela violência. É preciso que os/as profissionais tenham consciência da potencialidade desses paradoxos, para que sejam bem trabalhados em intervenções adequadas e instrumentalizadas para lidar com os padrões de duplo-vínculo. A variabilidade das respostas de muitos homens pode indicar o início do processo de reconhecimento do caráter relacional das situações de conflito conjugal e favorecer a sua adoção de estratégias de autocuidado, autorresponsabilização e de superação da violência.

Alguns participantes apresentaram ambiguidade de sentimentos e ao mesmo tempo o início de uma reflexão sobre sua responsabilização e possibilidade de mudança. A manifestação desses questionamentos é importante pelo fato de muitos homens se sentirem extremamente dependentes de uma companheira para cuidar deles. Ao mesmo tempo são estimulados socialmente a serem totalmente independentes. Esse paradoxo contribui para a utilização de algumas estratégias de duplo-vínculo usadas simultaneamente de forma consciente e inconsciente para a perpetuação da violência. Essas estratégias podem ser justificadas por vários comportamentos baseados em valores sociais internamente arraigados (Mahmoud, 2003). Os participantes desse estudo revelaram muitos motivos para permanecerem na relação e justificar a violência contra suas ex/companheiras baseados na dúvida sobre o afeto que elas sentiam ou poderiam ter sentido por eles. Essas justificativas evidenciam o valor de sobrevivência em relação às ex/parceiras (Angelim, 2009; Angelim \& Diniz, 2010; Separavich \& Canesqui, 2013; Souzas \& Alvarenga, 2001).

Essa ambivalência de sentimento deve ser bem avaliada nas intervenções com homens, pois podem atingir o seu extremo quando ocorre o paradoxo entre amor e ódio, geralmente associado ao valor de sobrevivência em relação ao cônjuge. A dinâmica duplo-vincular dificulta que homens e mulheres encontrem alternativas fora da relação. Eles/as podem estar aprisionados/as a esse padrão de relacionamento. Em muitos momentos, alguns homens podem vislumbrar a morte da ex/parceira e/ou a sua como a única forma de tentar resolver o problema, o que aumenta a chance de homicídio 
e/ou suicídio nessas situações. A socialização tradicional de homens, baseada principalmente no modelo hegemônico de masculinidade, contribui para a adoção de soluções drásticas. O homicídio e/ou o suicídio podem ser utilizados quando o homem encontra obstáculos para exercer o seu controle sobre a ex/parceira. A violência é estimulada tanto pelos aspectos que potencializam ou que ferem a masculinidade dos homens (Alves et al., 2012; Angelim \& Diniz, 2010; Camargo et al., 2011; Separavich \& Canesqui, 2013; Teixeira, 2009).

A manifestação de alguns paradoxos entre a violência e a ambiguidade de sentimentos é fundamental para iniciar o processo de conscientização dos homens para evitar a escalada da violência que pode culminar em grandes tragédias. Essa estratégia metodológica pode ter contribuído nesse sentido.

Outros homens trouxeram respostas que ajudam a compreender os paradoxos entre o discurso de negação das agressões e a presença de violência: "Não quero culpar ninguém; Cuida"; "Não precisava ter chegado a esse ponto.; Na hora da raiva e das humilhações a gente perde a cabeça; Por um motivo banal, besta gerou uma confusão, que chegou à polícia.”; "Tive falhas, mas não era pra ter ocorrido isso; Maltrata.; Não deu certo"; “Ainda vamos ser muito feliz.; Sim, dá amor e carinho; Amei muito também"; "Cuida; Eu não amava”. A respostas dos participantes indicam que o fato de não querer culpar ninguém, a expectativa de cuidado, de não precisar chamar a polícia ou de ter ocorrido o processo judicial, a esperança de ser muito feliz somente pelo fato de amar a parceira são fatores que favorecem que os homens não percebam a violência na relação. As narrativas dos participantes durante a reflexão grupal exemplificam bem essa negação da violência:

“A gente não via, é impressionante, era só briga, confusão, mas a gente só queria continuar, aí as brigas só piorava, mas ninguém queria ver, achava que ia ter um milagre e que ia ficar de boa." P17

"No meu caso eu não vi isso, não caiu a ficha quando a gente tava junto, eu to há mais de cinco anos divorciado. Eu perdi e nem percebi que perdi, não entendi o porque. Aqui você pediu um título, eu botei os erros que eu não percebi e magoa sem perceber. O relacionamento nosso sempre foi de muito companheirismo, de muito diálogo, muito respeito mesmo. Mas no mínimo a gente machuca a pessoa, no mínimo. Até umas coisas que passam despercebido, a gente magoa, distancia, você esfria o relacionamento. Não houve agressão, mas ao mesmo tempo houve, porque a mulher é muito assim, ela pode ser muito sensível, até se a gente não vê que ela cortou o cabelo, ela tá lá mexendo no cabelo e você vê, mas não fala, ai você já arrumou a confusão. Mas essas coisas são a gota d'água, a gente vacila muito, nunca é só isso" P48

A socialização masculina favorece essa negação da violência (Oliveira \& Gomes, 2011). A negação ocorre quando a pessoa não percebe a violência ou não reconhece a gravidade de suas consequências (Lila et al., 2012).

Alguns participantes foram capazes de revisar a inadequação do paradoxo entre amor/violência na relação e iniciaram o processo de reconhecimento do impacto da violência. 
Esse processo foi apresentado nas seguintes respostas dos homens da segunda etapa: "Sou mesmo o errado?; Ao bater arca com as consequências...; Fui encarcerado!”; “O erro está em mim; Cuida; Ai não duvidar"; “Amor imaturo; Cuida e dar carinho; Não deu certo"; “A minha mulher é muito ciumenta; Jamais eu lhe trisco"; "Por que de tantas arrogâncias (minha e dela); Cuida; Agora odiado"; "O erro foi eu; Perdoa e não trai; Não dei valor"; "Eu estava errado; Ama; Não fui amado"; "O erro está em nós; Sim procura resolver o problema; Não dei valor, mas nunca é tarde"; "A gente tem uma convivência boa; Arrepende depois; Fui correspondido"; "O machista; Quem bate se arrepende depois; Não dei valor”; “A falta de diálogo; Demonstra; Eu não amei”; “Os erros que não percebi; Magoa sem perceber; Cometi erros"; "Incapacitado; Perdoa; Não realizado"; “Será que eu sou o errado; Dá carinho, amor, respeito etc.; Não dei valor"; "Uma família é feliz quando sabe conversar; Quem não escuta pode agredir; Não fui ouvido". Algumas narrativas dos participantes durante a reflexão grupal ilustram bem esse início do reconhecimento da violência:

“O meu título foi 'o erro foi eu' porque a gente só quer apontar, dizer que ela tá errada, ai é muito fácil, mas a gente tem que se colocar no lugar da pessoa pra ter uma noção do que ela tá passando" P32

“O meu foi 'amor imaturo', porque passei pela dificuldade e a gente aprende. Os dois foram imaturos, eu e ela, mas a gente não via que não tava dando certo e queria continuar, ai veio as brigas. Hoje eu vejo." P17

"E no meu eu coloquei que eu não dei valor, mas não foi tarde, eu tive a oportunidade, porque eu não perdi, eu quase perdi, mas graças a Deus eu ainda estou com ela. Pelo menos hoje eu acho ela muito interessante, coisa que eu via e não dava valor mesmo. Hoje eu sei que é uma mulher que gosta muito de mim, porque se não gostasse não tava comigo" P39

"Eu vejo nos relacionamentos, nos homens em geral, a gente sai pra trabalhar, passa raiva o dia todo e a casa da gente vira uma válvula de escape. Às vezes, a gente descarrega tudo ali, tudo em cima da mulher. No meu título, a última frase eu escrevi assim: "cometi erros", "quem ama não bate, mas magoa sem perceber" e o meu título: "os erros que não percebi”. A gente não percebe, a gente fica cego, fica cego mesmo. E a mulher vai absorvendo igual esponja, absorvendo e absorvendo e a gente não vê que ela tá mal, que o relacionamento tá mal, e depois a gente não entende porque que termina, porque que vem parar aqui (...) A gente tem que ter mais tolerância, mais compreensão" P48

"É fácil chegar aqui e jogar a culpa na mulher né, eu tive que mudar algumas coisas, abrir mão de muitas coisas. Eu ficava a semana toda trabalhando, chegava final de semana era só bebida, sábado bebida, domingo bebida. Ela ia pra igreja, a gente não tinha um momento pra gente, de sair junto. Eu só pensava em mim. Hoje já mudou, sábado eu vou pra um lugar com ela, domingo nós vamos pra outro. Por isso eu escrevi [no título] 'o erro está em nós' e ‘to procurando resolver o problema', mas eu to procurando ver o meu erro aqui, eu que tenho que resolver o meu problema, eu to correndo atrás do prejuízo, nunca é tarde" P 39

"O meu título foi 'o machista' mesmo. Eu sempre tava com a razão, achava que eu era terrível, o bonzão. Ela queria ir comigo e eu não deixava, ela falava que as amigas iam com os maridos. Eu falava: 'só tem homem, você não vai não' (...). Por isso que os relacionamentos não dão certo, daí eu coloquei o machista, eu era assim 
(...) Eu completei 'quem ama não bate, mas se arrepende', foi o nosso caso aqui né, se arrepende depois" P42

"Há dois anos atrás eu participei de uma tarde de reflexão sobre a [Lei] Maria da Penha. Cara, quando eu entrei naquela sala, eu tava numa revolta, eu fiquei indignado, indignado com a Maria da Penha, para mim essa lei não valia nada, só protegia elas e tal. Hoje não, eu vejo que o erro tá na gente mesmo, que a gente tá crescendo no dia a dia, hoje eu vejo que a Lei é importante e que a gente tem nossos direitos de outra forma" P48

A estratégia utilizada pode ter facilitado a discussão sobre alguns fatores que impedem ou dificultam a reflexão de homens sobre a relação conjugal marcada pela violência - que ajuda a romper com a terceira condição do duplo-vínculo (Angelim, 2009; Angelim \& Diniz, 2010; Watzlawick et al., 1967/2007). Algumas respostas levantadas pelos participantes podem ter ajudado na identificação dos aspectos que mais aprisionam homens nessas dinâmicas marcadas pela violência: os papéis tradicionais de gênero; o silêncio e o segredo como estratégias de enfrentamento à violência; a instalação das anestesias relacionais; o ciclo da violência; a escalada gradual da violência; e o isolamento social da família.

Diante desses fatores que aprisionam os participantes, a estratégia metodológica pode ter facilitado a promoção ou o aprimoramento da capacidade dos homens de refletirem sobre as consequências deletérias a todos/as envolvidos/as da dinâmica conjugal estruturada pela violência (Angelim, 2009; Macedo, 2013; Pondaag, 2009). Esses recursos de reflexão podem favorecer o estabelecimento de limites para o próprio significado da experiência de violência para os homens. Os recursos podem, inclusive, ter ajudado no início do processo de superação do padrão de relacionamento duplo-vincular e na ampliação da capacidade de avaliar os riscos da violência para romper a terceira condição do duplo-vínculo, baseada na incapacidade ou dificuldade de refletir sobre os paradoxos da violência (Angelim \& Diniz, 2010; Watzlawick et al., 1967/2007).

O método proposto ajudou a iniciar a quebra da terceira condição de duplo-vínculo (Angelim, 2009; Angelim \& Diniz, 2010), pois contribuiu para que esses participantes manifestassem contradições e paradoxos de suas respostas. Essa manifestação pode abrir possibilidade para reflexão sobre vários aspectos da relação conjugal e de sua vida, inclusive sobre possíveis prejuízos de seguir um padrão de masculinidade hegemônico, que ainda impõe diversos duplo-vínculos aos homens atualmente. Esse modelo exerce várias pressões sociais e coloca diversos dilemas para a população masculina. Os homens são influenciados a reproduzir alguns privilégios das masculinidades, mas são simultaneamente estimulados a se oprimirem e se distanciarem de seus próprios sentimentos. A supremacia dos papéis masculinos também expõe e fragiliza os homens. Existe um paradoxo entre os privilégios e as vulnerabilidades dos homens que potencializa a violência conjugal (Alves et al., 2012; Alves \& Diniz, 2005; Maciel \& Barbosa, 2010; Medrado \& Méllo, 2008; Norman, 2011). 
Alguns participantes foram capazes de refletir sobre a inadequação de justificar a externalização da responsabilidade e a expectativa de conformismo da mulher. Esses homens puderam iniciar o processo de reconhecimento da importância de superar a ambiguidade de sentimentos. Eles perceberam a inadequação dos paradoxos entre amor/violência na relação. $\mathrm{Na}$ maioria dos casos, a reflexão sobre esses paradoxos foi acompanhada do intuito de adotar estratégias para mudar a história do relacionamento conjugal, o que pode ter facilitado, inclusive, a aceitação de encaminhamentos ao final do acompanhamento psicossocial.

A utilização dessa estratégia metodológica dentro de um contexto de acompanhamento psicossocial mais amplo, como por exemplo, em grupos reflexivos para homem, pode ter poderosos efeitos terapêuticos, mesmo que não se configurem como uma psicoterapia. A intervenção psicossocial pode criar uma rede de comunicações e de apoios sociais entre os homens, que ajuda a romper a terceira condição de duplo-vínculo: favorece a reflexão sobre a violência. A intervenção gera oportunidades para os participantes desafiarem as mensagens paradoxais, inclusive de valor de sobrevivência entre os cônjuges. Dessa forma, contribui para a superação do segundo e do primeiro critério de duplo-vínculo. Assim, aumenta a possibilidade desses homens se libertarem dos aprisionamentos diante dos paradoxos e iniciarem o processo de mudanças para superação da violência e de transformação da relação. Essa estratégia pode ajudar no reconhecimento que ambos têm o direito de viver livres e sem violência (Angelim, 2009; Angelim \& Diniz, 2010; BoydFranklin \& Franklin, 2003; Watzlawick et al., 1967/2007).

A correta aplicação das teorias sistêmicas pode fornecer diversas ferramentas para os/as profissionais que atuam na área de violência conjugal (Angelim, 2009; Angelim \& Diniz, 2010). Essa estratégia metodológica pode ser importante para ajudar na manifestação de indícios de anestesias relacionais e de critérios de duplo-vínculos da dinâmica na perspectiva de homens autores. Esse passo é fundamental para que na sequência do acompanhamento psicossocial essas questões possam ser trabalhadas e desconstruídas. O acompanhamento pode se constituir, então, como uma poderosa oportunidade de reflexão para homens sobre a relação marcada pela violência.

Uma análise detalhada das anestesias relacionais e dos critérios de duplo-vínculo carrega o potencial de revelar o quanto um relacionamento marcado pela violência conjugal pode estar alicerçado em padrões paradoxais, de difícil reconhecimento e superação. Essa análise deve ser feita à luz de uma perspectiva de gênero, no intuito de evitar a naturalização de algumas das contradições e paradoxos vividos pelas mulheres e homens nessas relações (Angelim \& Diniz, 2010).

As respostas às oito questões do questionário pelos homens participantes do estudo revelaram várias questões fundamentais para compreendermos os aspectos de suas vivências pessoais, relacionais e sociais em relação à violência conjugal. Para enriquecer ainda mais o 
trabalho, mostramos a seguir algumas respostas complementares de homens e mulheres que participaram simultaneamente dos Grupos Mistos na primeira etapa da pesquisa. Conforme o método do SERAV, a participação de membros do mesmo casal/ex-casal no acompanhamento psicossocial aconteceu no mesmo período, mas eles/as foram inseridos em grupos em dia e horários diferenciados.

É importante desenvolver novas propostas metodológicas de pesquisa e intervenção para favorecer o empoderamento das mulheres e de homens em situação de violência. A estratégia dessa pesquisa pode contribuir para que homens e mulheres manifestem e até percebam a tendência de justificar, de minimizar e até negar a própria experiência como violenta - geralmente baseados em mitos sociais. Esse passo pode ajudar em posterior conscientização de alguns paradoxos existentes na relação. Por isso, consideramos ser importante fazer uma discussão no próximo tópico sobre as vivências complementares de homens e mulheres em uma dinâmica conjugal marcada pela violência. Dessa forma, poderemos ter mais elementos para intervir junto aos homens e às mulheres para que ambos possam realmente se libertar da violência e transformar as relações conjugais.

\section{Complementaridade das vivências de homens e mulheres}

A violência conjugal aprisiona muitos casais ou ex-casais (Silveira et al., 2009). Diante do aspecto complementar dos inúmeros processos que compõem as tramas das dinâmicas conjugais em situação de violência, nós consideramos a importância de destacar e refletir também sobre as anestesias relacionais e os aspectos duplo-vinculares dos homens e das mulheres em conjunto. Nós incluímos cinco mulheres que eram parceiras ou ex-parceiras dos homens participantes da primeira etapa da pesquisa e que também compareceram ao Grupo Misto e preencheram os questionários.

Tivemos o objetivo de contemplar algumas especificidades do trabalho com homens em situação de violência conjugal e lidar com o desafio de ampliar as estratégias metodológicas em relação ao que foi trabalhado com as mulheres na pesquisa do mestrado (Guimarães, 2009). Essa amostra complementar foi importante para termos mais elementos para analisar as dinâmicas conjugais dos homens participantes, mas sem perder a priorização do estudo das masculinidades nesse trabalho. Apresentamos os resultados comparativos das respostas dos casos 4, 5, 9, 12 e 13, que tiveram a participação dos homens e das mulheres.

\section{Sentimentos despertados pelos/as participantes com a leitura do livro}

A Tabela 6.17 mostra a comparação entre os sentimentos despertados nos/as participantes com a leitura do livro em resposta à primeira pergunta do questionário. A primeira coluna da tabela apresenta o número indicativo de cada participante. A segunda coluna mostra os sentimentos dos homens e a terceira coluna o sentimento das mulheres. 
Tabela 6.17

Sentimentos dos/as Participantes ao Ler o Livro

\begin{tabular}{|c|c|c|}
\hline & Homens & Mulheres \\
\hline 4 & Eu me decepcionei comigo & $\begin{array}{l}\text { Eu senti o mesmo sofrimento que aquela mulher } \\
\text { passou }\end{array}$ \\
\hline 5 & Um sentimento de repúdio & $\begin{array}{l}\text { Sentimento que sempre aconteceu comigo o mesmo } \\
\text { dela }\end{array}$ \\
\hline 9 & $\begin{array}{l}\text { De arrependimento, que poderia ser e fazer melhor, ser mais } \\
\text { atencioso, saber amar quem te ama. }\end{array}$ & $\begin{array}{l}\text { Foi um sentimento de surpresa e ao mesmo tempo } \\
\text { que as coisas podiam mudar. Foi sentimento } \\
\text { inexplicável. }\end{array}$ \\
\hline 12 & Achei muito interessante & $\begin{array}{l}\text { Eu senti que estava ali dentro do livro como se fosse } \\
\text { a Roz. }\end{array}$ \\
\hline 13 & Saudades, vergonha, raiva de minha pessoa etc. & Nojo, ódio \\
\hline
\end{tabular}

Os resultados das respostas de homens e mulheres apresentados em conjunto permitem perceber que as respostas se complementaram sobre a percepção da dinâmica conjugal do livro. Tanto os homens quanto as mulheres apresentaram sentimentos fortes e aversivos em relação à situação de violência do casal protagonista. No entanto, os homens trouxeram aspectos de naturalização da violência e as mulheres se identificaram com a personagem do livro.

Eles/as descreveram sentimentos relacionados à decepção, repúdio, arrependimento, interesse, saudades, vergonha, raiva, surpresa, inexplicável, nojo, ódio. Três das cinco mulheres descreveram grande identificação com a personagem: de ter sentido o mesmo sofrimento da Roz, de ter acontecido o mesmo dela, de sentir que estava dentro do livro. O interesse pelo livro foi explícito por todos e todas participantes. O relato de uma das mulheres evidencia o impacto da leitura do livro: "Foi um sentimento inexplicável".

É fundamental estimular e/ou devolver a capacidade de reflexão de homens e mulheres sobre esses sentimentos. Podemos, assim, auxiliá-los/as para que compreendam melhor como eles/as ficam presos/as à relação por anestesiar as suas emoções. O fato de voltar a reconhecer e a ter contato com os sentimentos aversivos e fortes diante da violência pode ser o primeiro passo para libertação de ambos da violência conjugal (Guimarães, 2009; Macedo, 2013; Ravazzola, 1997, 1998). Dessa forma, essa estratégia metodológica apresentou seu potencial para ajudar homens e mulheres a superar essa dificuldade de reconhecer e expressar os seus sentimentos.

\section{Comparação entre a história do livro e as vivências dos homens e das mulheres}

A Tabela 6.18 indica os elementos que os homens e mulheres consideraram semelhantes e diferentes em relação à vivência dos personagens do livro. A primeira coluna da tabela apresenta o número indicativo de cada participante. A segunda e a terceira colunas mostram as respostas que os homens compreenderam como comuns e diferentes da história de Roz e Brian, respectivamente. A quarta e a quinta colunas expõe as respostas que as mulheres identificaram como semelhantes e diferentes, respectivamente. 
Tabela 6.18

Elementos Comuns e Diferentes entre a História dos/as Participantes e a dos Personagens do Livro

\begin{tabular}{|c|c|c|c|c|}
\hline & \multicolumn{2}{|c|}{ Homens } & \multicolumn{2}{|c|}{ Mulheres } \\
\hline & Comuns & Diferentes & Comuns & Diferentes \\
\hline 4 & Quando eu bebia álcool & Eu nunca traí minha esposa. & $\begin{array}{l}\text { Minha história é diferente. Mas o } \\
\text { Brian tinha as crises dele quando } \\
\text { bebia. O mesmo acontecia com } \\
\text { XXX. }\end{array}$ & $\begin{array}{l}\text { Meu marido nunca me traiu, } \\
\text { e nunca quis obrigar os } \\
\text { filhos a beber álcool. }\end{array}$ \\
\hline 5 & $\begin{array}{l}\text { Parecido só a respeito do } \\
\text { alcoolismo }\end{array}$ & Tudo & A ignorância e a falta de respeito & $\begin{array}{l}\text { Quase nada, quer dizer é } \\
\text { igual ao que aconteceu } \\
\text { comigo }\end{array}$ \\
\hline 9 & $\begin{array}{l}\text { Roz - no carinho, no acreditar e } \\
\text { na esperança que é a última que } \\
\text { morre, a vontade de dialogar, } \\
\text { sem saber o que fazer. Brian - } \\
\text { não dar valor na pessoa que está } \\
\text { ao seu lado querendo ver você } \\
\text { crescer, melhorar. }\end{array}$ & $\begin{array}{l}\text { Muita coisa, mas a minha perda } \\
\text { foi eu mentir muito, sair com } \\
\text { outras mulheres, eu não fui } \\
\text { agressivo fisicamente, mas fui } \\
\text { muito verbal e mentiroso, magoei } \\
\text { o sentimento. }\end{array}$ & $\begin{array}{l}\text { Tem algumas coisas em comum } \\
\text { que no começo é uma maravilha, } \\
\text { mas depois não sei o que acontece } \\
\text { que ele se revolta. }\end{array}$ & Nada. \\
\hline 12 & $\begin{array}{l}\text { Momentos bons e momentos } \\
\text { ruins, mais bons do que ruins. }\end{array}$ & Traição, porque eu nunca traí ela. & $\begin{array}{l}\text { Brian tem um pouco em comum } \\
\text { com meu marido porque bebia } \\
\text { muito, era muito agressivo e eu já } \\
\text { tive medo dele... }\end{array}$ & A traição. \\
\hline 13 & Algumas mentiras, bebidas. & Eu nunca traí (traição) & $\begin{array}{l}\text { Os pedidos de desculpas e as } \\
\text { promessas }\end{array}$ & Traições e as humilhações. \\
\hline
\end{tabular}

As mulheres apresentaram mais facilidade na identificação com a dinâmica apresentada pelos personagens do livro. Elas conseguiram identificaram mais elementos diante dessa comparação. Os principais elementos em comum identificados pelas participantes foram: abuso de álcool pelo ex/parceiro, a falta de respeito, presença do ciclo e da escalada da violência; sentimento de medo das agressões. O ciclo de violência foi identificado nos pedidos de desculpas e promessas, de ficar mais agressivo ao beber. A escalada da violência pode ser constatada no relato de a relação ser muito boa no início e ter ocorrido o aumento gradual das agressões.

A maioria dos homens percebeu como elemento comum o abuso de álcool, que foi relatado por três participantes. Outros dois homens perceberam o ciclo de violência como semelhante à história do livro.

Percebemos que os homens tiveram maior tendência a naturalizar a violência. Eles trouxeram mais aspectos que indicam a negação, minimização e/ou desresponsabilização da violência. Essa naturalização evidencia a existência de anestesias relacionais que dificultam a percepção do impacto da violência para esses ex/casais (Ravazzola, 1997, 1998).

O principal elemento percebido como diferentes tanto pelos homens quanto pelas mulheres foi a ausência de traição. Três homens e três mulheres citaram que não houve infidelidade em suas vivências. Os outros dois homens descreveram a ausência de agressão física e que tudo era diferente, respectivamente. As outras duas mulheres identificaram que nada ou quase nada era diferente.

Esses dados divergem dos resultados da pesquisa do mestrado (Guimarães, 2009). Naquele estudo, a grande maioria das mulheres identificou-se com a vivência de infidelidade dos personagens do livro. As participantes daquela pesquisa trouxeram os seguintes relatos dessa 
experiência aversiva: "ele enganava, traia"; "ele prezar tanto a fidelidade e não retribuir com a mesma fidelidade"; "as mentiras que conta que são iguais as da história". Seis mulheres dentre as 19 participantes mencionaram que a infidelidade e as agressões eram vivenciadas de forma associada. Essa associação foi exemplificada nos seguintes trechos: "traição, amor e violência”; "a traição e a violência física", “a violência e a traição". Souzas e Alvarenga (2001) afirmam que a infidelidade pode ser a uma das diversas portas de entrada da violência conjugal.

As diferenças entre os dados da pesquisa de mestrado e dessa tese reforçam a diversidade das conjugalidades das relações marcadas pela violência. Os elementos identificados pelos/as participantes do presente estudo como semelhantes e diferentes em relação à vivência dos personagens do livro revelaram três categorias de percepções entre os homens e as mulheres. As respostas foram convergentes, parcialmente convergentes e outras divergiram totalmente de acordo com a percepção de cada casal ou ex-casal ao comparar as dinâmicas conjugais próprias e a do livro.

Um casal e um ex-casal tiveram respostas totalmente convergentes e complementares ao comparar os elementos semelhantes e diferentes em relação ao casal do livro. O homem e a mulher do casal referente ao Participante 4 identificaram como elementos comuns o abuso de álcool do homem e como diferente a ausência de traição. Já os membros do ex-casal alusivo ao Participante 13 perceberam como semelhante o ciclo de violência e como diferente a infidelidade. $\mathrm{O}$ casal (Participante 4) estava junto e convivia maritalmente há 26 anos. O ex-casal (Participante 13) estava separado há 36 meses.

Esse fato evidência que estar separados ou juntos não determina se as percepções dos membros do casal/ex-casal serão parecidas ou divergentes. Mais importante do que estar junto ou separado, é como se dá a relação durante a convivência e/ou depois da separação (Nichols \& Schwartz, 2007; Vazquez, 2014).

Um casal teve percepção totalmente contrária e divergente ao descrever essa comparação. Os membros do casal referente ao Participante 5 divergiram tanto nos aspectos comuns quanto nos diferentes. Ele identificou como semelhante entre sua vivência e a do livro somente o alcoolismo dele e do Brian, ela descreveu a ignorância e a falta de respeito. Quanto aos aspectos diferentes, ele compreendeu que era tudo, ela percebeu que era quase nada e enfatizou que a história de Roz era igual à dela. Esse casal convivia maritalmente há 11 anos. Essa divergência pode evidenciar dificuldades comunicacionais entre ele/a e ser um fator de risco para a re/instalação da violência (Guimarães, 2009; Medeiros, 2015).

Os outros dois casais tiveram um aspecto complementar e uma divergência nas respostas descritas pelos seus membros. $\mathrm{O}$ casal referente ao Participante 9 teve respostas convergentes ao 
descrever os aspectos comuns, ambos relataram a existência do ciclo de violência. Eles divergiram na compreensão dos parâmetros diferentes de sua relação. Ele descreveu que percebia muita coisa diferente ao comparar sua história com a do livro, frisou especialmente que ele não foi agressivo fisicamente. Ela compreendeu que nada era diferente, percebendo muito mais aspectos em comum entre a vivência pessoal e a narrada no livro. Os dois eram noivos há cinco anos.

O casal referente ao Participante 12 divergiu em um aspecto de comparação e convergiu em outro. Os dois tiveram respostas parecidas quanto aos aspectos diferentes, ambos compreenderam a ausência de infidelidade na relação. No entanto, divergiram na compreensão dos aspectos comuns, o homem frisou a oscilação entre momentos bons e ruins, a mulher evidenciou o abuso de álcool, a presença de agressões e o sentimento de medo dele. O casal estava casado há 12 anos.

O quinto axioma da Teoria da Comunicação descrita pelo grupo de MRI também ajuda a compreender essa diversidade de percepções entre os ex/casais participantes do estudo, especialmente quanto às interações comunicacionais. Essa teoria defende que existem duas características principais na comunicação entre os casais: uma de simetria e outra de complementaridade. Essas relações geralmente se baseiam nas dimensões de igualdade e diferenças entre os cônjuges. No primeiro caso, cada ex/parceiro/a reflete o comportamento um do outro, caracterizada pela igualdade e pela minimização da diferença. No segundo, o comportamento de um complementa o do outro, baseando-se na maximização da diferença (Watzlawick et al., 1967/2007; Zordan, Dellatorre \& Wieczorek, 2012).

Essa teoria reforça que não há problema em divergir ou convergir sobre essa comparação com a história do livro ou outros aspectos em suas conjugalidades. A questão importante é como os membros dos casais lidam com as divergências comunicacionais na relação. Muitos ex/casais conseguem superar as suas diferenças e crescer com as crises. Outros transformam essas diferenças em desigualdades e violência (Nichols \& Schwartz, 2007; Vazquez, 2014; Watzlawick et al., 1967/2007; Zordan et al., 2012). Essa proposta metodológica pode ser importante para ajudá-los a manifestar essas diferenças. Intervenções posteriores no contexto grupal e/ou intervenções conjugais podem ajudá-los a refletir sobre essas diferenças comunicacionais e podem favorecer a superação dos conflitos por meio da aceitação da diversidade e de formas mais democráticas de se relacionar em suas conjugalidades (Brah, 2006; Scott, 1995, 2005).

A reflexão sobre as respostas dos homens e mulheres ao compararem as suas vivências com a história dos personagens do livro têm o potencial de considerar e enfatizar a variabilidade das conjugalidades (Graham-Kevan, 2007; Medeiros, 2015; Oliveira \& Gomes, 2011; Silveira et al., 2009; Teixeira, 2009). Entendemos que o reconhecimento dessa diversidade pelos profissionais facilita a escuta desses/as homens e mulheres como seres humanos, não apenas como meros 
agressores e vítimas. A superação dessa cristalização e rotulação das pessoas envolvidas na violência conjugal é fundamental para uma intervenção adequada a esses casos. Dessa forma, os profissionais podem acreditar, priorizar e investir mais na possibilidade de superação da violência e de mudança das masculinidades, feminilidades e conjugalidades. Essa visão mais ampla possibilita também abranger esses homens e essas mulheres como os/as principais agentes de mudanças para a superação e transformação de sua própria relação conjugal (Beiras \& Cantera, 2012; Separavich \& Canesqui, 2013).

\section{Reflexão sobre as anestesias relacionais dos homens e das mulheres}

$\mathrm{Na}$ quarta e quinta perguntas os/as participantes puderam escolher as anestesias que identificaram como presentes em suas próprias histórias. Eles tiveram como estímulo as anestesias descritas e ilustradas pela Roz no livro Mas ele diz que me ama (Penfold, 2005/2006). A Tabela 6.19 revela as anestesias relacionais mais marcadas pelos homens e pelas mulheres.

Tabela 6.19

Anestesias mais Marcadas pelos/as Participantes

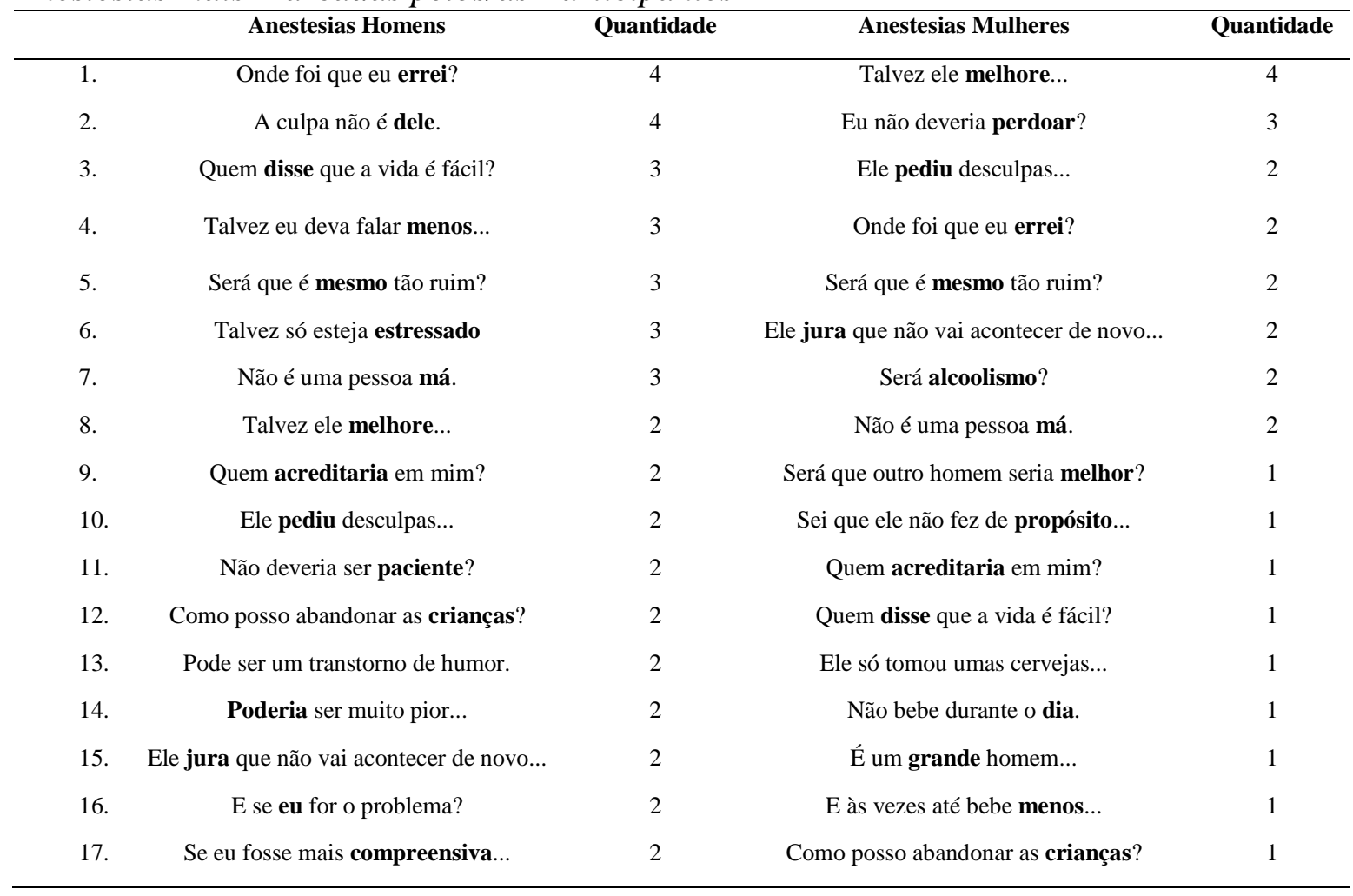

A primeira coluna da tabela apresenta o número indicativo de cada participante. A segunda coluna mostra as anestesias mais assinaladas pelos homens e a terceira coluna a quantidade de vezes que cada anestesia foi escolhida pelos participantes. A quarta coluna evidencia as anestesias que as mulheres mais se identificaram e a quinta coluna a quantidade de vezes que foram citadas por elas. Apresentamos as anestesias que foram marcadas por pelo menos dois participantes. 
As anestesias que os homens mais se identificaram foram: “Onde foi que eu errei?”, “A culpa não é dele.”. As mulheres escolheram outras anestesias. As mais importantes para elas foram: "Talvez ele melhore..." e "Eu não deveria perdoar?".

Dentre as 35 anestesias listadas no livro, 31 foram marcadas pelo menos uma vez pelos homens e 27 pelas mulheres. Oito anestesias foram citadas por mais da metade dos homens e duas pelas mulheres, o que indica um alto reconhecimento de sua influência na manutenção da violência conjugal pelos homens autores e mulheres vítimas de violência.

A Tabela 6.20 exibe a quantidade de anestesias relacionais marcadas por cada participante. A primeira coluna mostra o caso referente a cada participante. A segunda coluna mostra a quantidade de anestesia escolhida pelos participantes. A terceira coluna evidencia a quantidade de anestesias das participantes.

Tabela 6.20

\begin{tabular}{ccc}
\multicolumn{2}{c}{ Quantidade de Anestesias } & Marcadas por Cada participante \\
\hline Caso & $\begin{array}{c}\text { Quantidade } \\
\text { Homens }\end{array}$ & $\begin{array}{c}\text { Quantidade } \\
\text { Mulheres }\end{array}$ \\
\hline $\mathbf{4}$ & 3 & 6 \\
$\mathbf{5}$ & 8 & 3 \\
$\mathbf{9}$ & 18 & 6 \\
$\mathbf{1 2}$ & 19 & 16 \\
$\mathbf{1 3}$ & 9 & 7 \\
\hline
\end{tabular}

A quantidade de anestesias selecionadas pelos homens variou entre 3 a 19 e a das mulheres de 3 a 16. Esse fato mostra certa semelhança na amplitude máxima e mínima de anestesias marcada pelos/as participantes.

A Tabela 6.21 resume a comparação da quantidade de anestesias relacionais marcadas pelos/as participantes. A primeira coluna mostra o caso referente a cada participante. A segunda coluna mostra a média, quantidade mínima e máxima de anestesias escolhidas pelos homens. A terceira coluna evidencia essas informações sobre as anestesias das mulheres.

Tabela 6.21

Comparação da quantidade de anestesias marcadas por cada participante

\begin{tabular}{ccc}
\hline & $\begin{array}{c}\text { Total } \\
\text { Homens }\end{array}$ & $\begin{array}{c}\text { Total } \\
\text { Mulheres }\end{array}$ \\
\hline Média & 11,4 & 7,6 \\
Mínima & 3 & 3 \\
Máxima & 19 & 16 \\
\hline
\end{tabular}

A média foi de 11,4 anestesias para os homens e 7,6 anestesias para as mulheres. A média dos homens foi muito acima que a das mulheres, os participantes marcaram mais anestesias que suas ex/parceiras. Esse fato pode sinalizar uma maior naturalização de aspectos que lhes impediram de reconhecer as consequências e os riscos da violência conjugal (Ravazzola, 1997, 1998). 
A pergunta 5 do questionário tinha o comando para os homens e as mulheres escolherem três das 35 anestesias que eles/as perceberam como mais importantes na vivência da relação marcada pela violência. A Tabela 6.22 apresenta essas anestesias pelos/as participantes.

Tabela 6.22

Anestesias Consideradas Mais Influentes pelos/as Participantes

\begin{tabular}{lllc}
\hline Anestesias Homens & $\begin{array}{c}\mathbf{N}^{\circ} \text { de } \\
\text { participantes }\end{array}$ & \multicolumn{1}{c}{ Anestesias Mulheres } & $\begin{array}{c}\mathbf{N}^{\circ} \text { de } \\
\text { participantes }\end{array}$ \\
\hline Quem disse que a vida é fácil? & 2 & Talvez ele melhore... & 3 \\
Talvez eu deva falar menos... & 2 & Eu não deveria perdoar? & 1 \\
Talvez ele melhore... & 1 & Sei que ele não fez de propósito... & 1 \\
Eu não deveria perdoar? & 1 & Quem acreditaria em mim? & 1 \\
Onde foi que eu errei? & 1 & Ele pediu desculpas... & 1 \\
Como posso abandonar as crianças? & 1 & É um grande homem... & 1 \\
Poderia ser muito pior... & 1 & Será que é mesmo tão ruim? & 1 \\
Será que é mesmo tão ruim? & 1 & E se eu for o problema? & 1 \\
Talvez só esteja estressado & 1 & Sei que ele me ama... & 1 \\
Ele jura que não vai acontecer de novo... & 1 & Será alcoolismo? & 1 \\
E se eu for o problema? & 1 & Não é uma pessoa má. & 1 \\
Não é uma pessoa má. & 1 & Se eu fosse mais compreensiva... & 1 \\
A culpa não é dele. & 1 & Se eu me esforçar mais... & 1 \\
\hline
\end{tabular}

A maioria dos/as participantes escolheu e escreveu até três anestesias no campo apropriado do questionário. As anestesias mais relevantes na visão dos participantes foram "Quem disse que a vida é fácil" e "Talvez eu deva falar menos...”. Para as mulheres foi a "Talvez ele melhore...".

O objetivo da pergunta 6 do questionário foi averiguar quais anestesias os/as participantes consideravam importantes a partir de suas próprias histórias, ou seja, eles/as tinham a opção de acrescentar anestesias advindas de sua própria experiência e que não estavam listadas no estímulo fornecido. A Tabela 6.23 mostra as anestesias relacionais identificadas pelos/as próprios/as participantes sem os estímulos do livro.

Tabela 6.23

\begin{tabular}{|c|c|c|c|c|}
\hline \multicolumn{2}{|r|}{ Anestesias Homens } & Quantidade por & Anestesias Mulheres & Quantidade por \\
\hline 4 & Eu não vou perder minha família & 1 & - & 0 \\
\hline 5 & - & 0 & $\begin{array}{c}\text { Tinha medo de sofrer com meus } \\
\text { filhos; } \\
\text { Hoje eu não tenho medo mais. }\end{array}$ & 2 \\
\hline 9 & $\begin{array}{l}\begin{array}{l}\text { Envolvimento familiar (para sair do } \\
\text { relacionamento); }\end{array} \\
\text { Vergonha, falta de oportunidade (pedir } \\
\text { ajuda); } \\
\text { Falta coragem, falta diálogo, pulso firme, pé } \\
\text { no chão. }\end{array}$ & 3 & $\begin{array}{c}\text { Foi mais por causa do medo dele } \\
\text { fazer alguma coisa contra mim; } \\
\text { Por vergonha de denunciar só porque } \\
\text { é meu noivo. }\end{array}$ & 2 \\
\hline 12 & - & 0 & - & 0 \\
\hline 13 & $\begin{array}{c}\text { Desabafo; } \\
\text { Ódio; } \\
\text { Arrependimento. }\end{array}$ & 3 & $\begin{array}{c}\text { Medo; } \\
\text { Vergonha. }\end{array}$ & 2 \\
\hline
\end{tabular}


Os homens conseguiram levantar sete e as mulheres seis anestesias. Três homens e três mulheres identificaram anestesias próprias de sua vivência. Os homens trouxeram respostas que mostram que as anestesias criadas e percebidas por eles foram o medo de perder a família, o envolvimento de terceiros, falta de oportunidade de pedir ajuda, de ausência de diálogo no relacionamento e a influência de diversos sentimentos aversivos, tais como vergonha, medo, desabafo, ódio, arrependimento.

As principais anestesias próprias identificadas pelas mulheres foram a vergonha e o medo tanto de novas agressões dos parceiros ou de como seria a vida após a separação ou a denúncia, inclusive de não ter condições de sustentar os filhos e aumentar o sofrimento deles. Esse resultado coincidiu com a pesquisa desenvolvida no mestrado. As participantes daquele estudo também identificaram esse medo como o maior empecilho para superar a violência. As mulheres vítimas de violência conjugal tendem a permanecer na relação e tolerar anos a fio as múltiplas formas de agressões. A certeza de que vão encontrar muitos empecilhos adia e/ou dificulta a decisão de saída do relacionamento (Guimarães, 2009).

Esses dados revelam que existem diversos obstáculos para homens e mulheres lidarem e superarem a violência, seja permanecendo na relação ou separando do/a parceiro/a. As dificuldades vão desde a expectativa de como será a reação dos familiares, dos amigos e da sociedade ao medo da reação e das ameaças do parceiro (Guimarães, 2009). Oliveira \& Gomes (2011) corroboram essa ideia e defendem a falta de responsabilização dos homens em relação às agressões e as justificativas e queixas das mulheres vítimas atuam conjuntamente em prol da manutenção da violência.

Ravazzola (1997, 1998) afirma que a análise comparativa das anestesias de mulheres e de homens em uma dinâmica conjugal permite identificar a presença de algumas coincidências e complementaridades em diversos níveis. Tais coincidências e complementaridades contribuem para sustentar e justificar a violência, permitindo e contribuindo para que ela se repita, cresça e se perpetue.

O maior problema dessas anestesias é que a sua coincidência com uma tendência social dos próprios homens em situação de violência conjugal: a naturalização da violência por meio da negação, minimização e desresponsabilização de seus atos. Isso pode servir para justificar suas condutas de forma complementar, por eles mesmos, pelas ex/parceiras e pelos profissionais (Aguiar, 2009; Guimarães, 2009; Machado, 2000). Por isso, é importante ajudar tanto os homens quantos as mulheres a manifestarem as anestesias que os aprisionam às relações marcadas e estruturadas pela violência.

Esse estudo teve o objetivo de contribuir para a identificação de algumas anestesias de ambos os membros do ex/casal de forma complementar. Entendemos que assim, profissionais 
podem ajudá-los/as no decorrer do acompanhamento psicossocial que eles e elas possam ter mais condições de superar os fatores que dificultam a compreensão das consequências e dos riscos da violência conjugal. Compreendemos que essa forma de análise deve ser estendida aos paradoxos que estruturam algumas conjugalidades. Assim, discutimos a seguir os principais aspectos complementares de homens e mulheres referentes à nomeação das relações marcadas pela violência, que podem indicar a existência de critérios de duplo-vínculos em algumas dinâmicas conjugais.

Duplo-vínculos e nomeação da violência conjugal pelos homens e pelas mulheres

As duas últimas perguntas do questionário tiveram como objetivo conhecer como os/as participantes nomearam e perceberam a própria história tendo como estímulo o título do livro "Mas ele diz que me ama" (Penfold, 2005/2006). A Tabela 6.24 revela a nomeação da própria vivência conjugal pelos homens e pelas mulheres a partir do título do livro como estímulo. A análise conjunta das duas respostas de cada membro dos casais/ex-casais pode auxiliar no entendimento de algumas características duplo-vinculares de dinâmicas relacionais de alguns homens e mulheres envolvidos/as na violência conjugal.

A primeira coluna da tabela apresenta o número indicativo de cada participante. A segunda e a quarta colunas mostram as resposta ao item sete do questionário pelos homens e pelas mulheres, respectivamente. Esse item solicitou aos/às participantes nomearem a sua vivência com a seguinte instrução: “A Roz resumiu a história dela com o título: 'Mas ele diz que me ama...'. Qual seria o título da sua história?". As respostas ao item oito do instrumento pelos homens e pelas mulheres estão descritas na terceira e na quinta colunas da tabela, respectivamente. O comando dessa questão para os/as participantes foi: "Inspirado em sua história, complete a frase/título do livro: "Mas ele diz que me ama...".

A análise dessas respostas em conjunto foi feita com base no entendimento que a resposta à questão sete do instrumento pode possibilitar aos/às participantes exporem as anestesias que os/as aprisionavam ou os/as aprisionam a relação conjugal. A resposta ao item oito pode priorizar a constatação de que há algo errado no relacionamento: estimulados pela palavra "mas" do título do livro.

A análise conjunta das duas respostas permite fazer uma reflexão sobre alguns paradoxos entre as anestesias apresentadas pelos homens e pelas mulheres, bem como uma análise inicial da percepção da realidade da violência em suas conjugalidades. Essa análise pode auxiliar no entendimento de algumas características duplo-vinculares de dinâmicas conjugais de alguns/mas participantes. 
Tabela 6.24

Título e Nomeação das Próprias Histórias pelos/as Participantes

\begin{tabular}{|c|c|c|c|c|}
\hline & Título & $\begin{array}{l}\text { Complemento da frase } \\
\text { "Mas ele diz que me ama... }\end{array}$ & Título & $\begin{array}{l}\text { Complemento da frase } \\
\text { "Mas ele diz que me ama... }\end{array}$ \\
\hline 4 & Mas ela é religiosa & Por que fiz isso? & $\begin{array}{l}\text { Mas eu sempre fui uma } \\
\text { boa mulher }\end{array}$ & Então ele precisa mudar \\
\hline 5 & Quem ama não bate & Mas era só ilusão & $\begin{array}{l}\text { Acho que ele não me } \\
\text { ama }\end{array}$ & $\begin{array}{l}\text { Se ele me amasse ele não faria o que fez } \\
\text { comigo }\end{array}$ \\
\hline 9 & $\begin{array}{l}\text { Fui amado, mas não soube } \\
\text { amar }\end{array}$ & Mas não agi com amor & $\begin{array}{l}\text { Por que ele era tão } \\
\text { grosso comigo }\end{array}$ & E porque ele era tão frio assim \\
\hline 12 & $\begin{array}{l}\text { Até que as coisas começam a } \\
\text { mudar... }\end{array}$ & Mas tudo pode mudar... & $\begin{array}{l}\text { Ele sempre disse que } \\
\text { me amou... }\end{array}$ & Do jeito dele. \\
\hline 13 & Será que o erro está em mim? & $\begin{array}{l}\text { Mas porém a pessoa que ama não trai, } \\
\text { bate, não menti. }\end{array}$ & Me deixei levar & Mas não é o que parece \\
\hline
\end{tabular}

A nomeação/intitulação da própria história pelos/as homens e mulheres revelou alguns paradoxos da presença da violência na relação dos/as participantes. A partir da análise dos títulos foram identificadas, inclusive, várias complementaridades nas respostas dos membros dos ex/casais.

Diversos elementos da relação foram importantes para os/as participantes descreverem respostas que revelaram alguns paradoxos das relações conjugais tanto pelos homens quanto pelas mulheres. Eles/as trouxeram aspectos relacionados à religiosidade, de ser boa mulher, de ter sido iludido e, especialmente, relacionado ao afeto - de ser amado/a e esse afeto justificar a tolerância ou a permissividade à violência. Cinco homens e mulheres trouxeram referências diretas ao sentimento de "amor". Essa associação paradoxal entre a coexistência do amor e da violência pode revelar a presença de mensagens paradoxais exercidas por pessoas de grande valor afetivo, que dificultam a reflexão sobre a relação conjugal estruturada pela violência (Angelim, 2009; Angelim \& Diniz, 2010).

As respostas dos/as homens e mulheres trouxeram indícios de um início do processo de questionamento do relacionamento marcado pelo valor de sobrevivência, questão fundamental para posteriormente iniciar o processo de romper com alguns paradoxos e elaborar estratégias para superar a violência (Angelim, 2009; Angelim \& Diniz, 2010).

Esses questionamentos podem ser identificados principalmente nas respostas de ambos à questão oito do instrumento. As mulheres enfatizaram o questionamento da obrigatoriedade de ser uma boa mulher, da necessidade de mudança do parceiro, de questionar o amor que ele promete, de não aceitar as grosserias, a frieza e o "jeito" dele amar. Elas conseguiram manifestar, inclusive, sobre sua corresponsabilidade, da importância de não se deixar levar pelo parceiro e/ou pela relação. A manifestação desses questionamentos é importante para ajudar na retomada da capacidade de reflexão para que as mulheres não aceitem a imposição da prioridade da manutenção da família e a valorização do papel do homem em detrimento da sua própria integridade e sua saúde (Angelim, 2009; Angelim \& Diniz, 2010).

De forma complementar, os homens revelaram muitos questionamentos sobre a inadequação em permanecerem em uma relação com violência. Essa reflexão é importante para eles 
não justificarem as agressões contra suas ex/companheiras. Os participantes começaram a questionar a naturalização dessas agressões, se realmente amavam a parceira, o fato de ter se iludido, de ter sido amado e não saber amar, o que fizeram de errado. Essas reflexões favoreceram a expectativa de o relacionamento poder mudar para melhor ou de retomar a vida após a separação.

A reflexão sobre esses aspectos é fundamental para que os participantes consigam questionar algumas justificativas utilizadas por homens autores de violência que revelam a desigualdade na relação conjugal e reforçam o valor de sobrevivência em relação à parceira. A imposição de papéis sociais favorece a dependência entre os cônjuges ao dispor os homens como provedores e dominadores e as mulheres como subordinadas. Esses aspectos relacionados aos papéis tradicionais de gênero embasam a naturalização da violência conjugal pelos/as participantes de forma complementar (Angelim, 2009; Beauvoir, 1967, 1946/2000; Fávero, 2010; Separavich \& Canesqui, 2013; Souzas \& Alvarenga, 2001).

Para Simone de Beauvoir (1967, 1946/2000), existe uma estereotipia do comportamento feminino. As mulheres ficam subjetivamente dependentes do lócus conjugal e familiar. A expectativa social das mulheres resumirem suas vidas ao mundo privado do lar dificulta a reflexão das mesmas sobre sua condição subjetiva (Angelim, 2009; Diniz, 1999). A socialização de homens por meio da influência de seus pares, da família e da sociedade favorece a utilização da violência como algo natural, inclusive contra as ex/parceiras. Assim, esses homens ficam com extrema dificuldade de reconhecer e falar sobre a violência. As mulheres têm papel complementar à agressividade do papel masculino. São encorajadas a culpabilizar a si mesmas. Essa complementaridade forma um "laço duplo". Ambos ficam com extrema dificuldade de refletir sobre as consequências da relação marcada pela violência conjugal (Fávero, 2010).

O ciclo de violência também colabora para que homens e mulheres permaneçam na relação de forma complementar. Geralmente após um episódio de agressão, alguns homens podem dar assistência à mulher, pedir desculpas, mostrarem-se arrependidos e com remorso, fazerem promessas e usarem mecanismos de sedução. Na maioria dos casos, mais do que uma tentativa de enganar a parceria, muitos homens têm convicção de que conseguirão não recorrer mais à violência. Muitas mulheres tentam acreditar e criam esperança de que o parceiro realmente possui capacidade para mudar (Walker, 1999). Essa expectativa de mudança na relação dificulta a reflexão do casal sobre a dinâmica da violência. E, lamentavelmente, sem a busca de ajuda a tendência é a retomada das fases mais violentas do ciclo. Os momentos de tranquilidades tendem a ficar cada vez mais curtos e raros (Guimarães, 2009; Guimarães et al., 2007; Soares, 2005).

A violência conjugal configura como um elo que aprisiona muitos casais ou ex-casais (Silveira et al., 2009). Por isso, diante de tantos aspectos que favorecem de forma complementar 
para que homens e mulheres fiquem aprisionados à dinâmica relacional, a busca de ajuda externa é fundamental em vários casos. Os profissionais devem criar estratégias criativas para ajudar homens e mulheres a identificarem e auxiliarem na compreensão dos critérios do duplo-vínculo da dinâmica que alicerçam a relação marcada pela violência conjugal. Esse pode ser o primeiro passo para ajudar os/as envolvidos/as nessas dinâmicas. Essa etapa é fundamental para que eles e elas possam buscar ajuda e proteção.

É importante desenvolver novas propostas metodológicas de pesquisa e intervenção para favorecer o empoderamento das mulheres e de homens em situação de violência. Esse desenvolvimento pode contribuir para que ambos percebam a tendência de minimizar, de justificar e até negar a própria experiência como violenta baseados em mitos sociais e em estereótipos de gênero. Por fim, pode conscientizá-los/as dos diversos paradoxos existentes em muitas dinâmicas. Essa estratégia pode ser útil nesse sentido. Dessa forma, poderemos ter mais condições para que homens e mulheres realmente possam transformar as relações sociais e conjugais e se libertarem da violência. 


\title{
Capítulo 6
}

\section{Compreensão das masculinidades como meio de superar a violência conjugal}

\author{
Fala um pouco \\ Tua voz tá tão presa \\ Nos ensina esse jogo da vida \\ Onde vida só paga pra ver \\ (...) \\ Você foi meu herói, meu bandido \\ Hoje é mais muito mais que um amigo \\ Nem você, nem ninguém tá sozinho \\ Você faz parte desse caminho \\ Que hoje eu sigo em paz \\ (Música: Pai - Fábio Júnior)
}

A partir de abordagem sistêmica feminista e de gênero, essa pesquisa de doutorado teve o intuito de verificar se homens autores manifestam a tendência de naturalizar a violência ao compararem a história do livro com as próprias vivências. Pretendemos analisar se homens conseguem perceber o sofrimento dos personagens do livro e se essa identificação favorece a reflexão sobre o próprio padrão conjugal.

A violência conjugal impõe desafios imensos. Ela forma um elo que aprisiona homens e mulheres à dinâmica relacional. Somos otimistas e lutamos por um futuro de paz, mesmo sabendo que a violência é parte estruturante das relações em nossa sociedade. A violência é um instrumento utilizado historicamente pela humanidade para lidar com os seus conflitos. Imaginar um mundo sem violência conjugal ainda é uma utopia em nosso contexto. Alcançar a paz nos lares é algo bem complicado de se concretizar atualmente. No entanto, apostamos que é totalmente alcançável - a médio e longo prazo - um mundo em que as pessoas não naturalizem, minimizem e tolerem tanto a violência. Apostamos que podemos e devemos diminuir significativamente os números alarmantes de violência. Incluir os homens autores de violência conjugal como um dos agentes de mudança e transformação é fundamental para alcançar esse objetivo.

Infelizmente, mesmo com diversos avanços sociais e legais, a violência conjugal ainda tem permissão social para existir e se manter. A naturalização e a banalização das diversas formas dessa violência dificultam a sua percepção pelos/as envolvidos/as e pela sociedade. A socialização masculina também contribui para essa invisibilidade da violência. A construção social das masculinidades é contraditória. O mesmo sistema que brutaliza os homens, simultaneamente lhe confere privilégios e poder. As consequências desse condicionamento paradoxal são gravíssimas e repercutem em toda a sociedade. Esse sistema naturaliza a associação da masculinidade à agressividade. Essa naturalização contribui também para que muitos homens reprimam suas necessidades, dificuldades, sentimentos e várias outras formas de expressão e reconhecimento de 
afeto (Fávero, 2010; Medrado, 2009; Nascimento et al., 2009; Silveira et al., 2009; Toneli et al., 2010).

A nossa sociedade precisa reconhecer essas questões culturais que marcam, enrijecem e estigmatizam a população masculina. Esse reconhecimento pode ser um primeiro passo para superar esse padrão de socialização que aprisiona homens e mulheres, inclusive em dinâmicas conjugais marcadas pela violência. Precisamos construir mecanismos para quebrar a forte associação entre violência e masculinidades. Devemos desconstruir os mitos e os estereótipos de que a violência é naturalizada, justificada, aceita, permitida e necessária entre homens em muitos contextos. Temos que inventar novas formas de relações humanas que não tenham a violência como estrutura (Beiras \& Cantera, 2012; Fávero, 2010; Separavich \& Canesqui, 2013).

O método utilizado nesse trabalho - leitura do livro e preenchimento do questionário associados à reflexão grupal - facilitou a conscientização de muitos participantes sobre como as suas concepções estereotipadas de gênero e a manutenção de dinâmicas conjugais marcadas pela violência são prejudiciais a todos/as envolvidos/as na relação (Alvarenga, 2012; Juras, 2009; Oliveira, 2015; Silva, 2012, Siqueira, 2012). Vários participantes reconheceram e nomearam, inclusive, como essas dinâmicas são extremamente deletérias aos próprios homens autores de violência conjugal (Araújo, 2012; Macedo, 2013; Randle \& Graham, 2011).

Nós tivemos a pretensão de refletir sobre os aspectos de duplo-vínculos e as anestesias relacionais da dinâmica conjugal na perspectiva dos homens autores de violência conjugal. A estratégia metodológica utilizada nesse estudo foi um relevante espaço de escuta e uma valiosa oportunidade de percepção e resignificação da violência por esses homens. Esse trabalho resume essa experiência, alguns resultados merecem destaque.

A leitura da história do casal protagonista do livro teve grande repercussão nos participantes. A vivência de mal-estar com o contato com a história do livro foi relatada por 37 homens dentre os 45 participantes da segunda etapa. As respostas dos participantes referentes a esses sentimentos foram divididas em três categorias: 1) sentimentos aversivos gerais, sem aplicar diretamente ao seu relacionamento; 2) identificação de sentimentos aversivos relacionados às próprias vivências; e 3) sentimentos/descrições de fatos que revelaram negação de vivência parecida com os personagens.

A leitura facilitou o processo de percepção e reconhecimento da violência no próprio relacionamento conjugal por muitos participantes. Essa associação direta entre a história do livro e a vivência pessoal apareceu nas respostas de sete homens na primeira etapa e por outros sete participantes na segunda etapa. A leitura do livro pode facilitar o processo de percepção e reconhecimento da violência no próprio relacionamento conjugal, pois muitos homens transferiram o mal-estar sentido pelo contato e identificação com a história dos personagens à sua vivência. $\mathrm{O}$ 
método utilizado nesse estudo favoreceu a emergência desses sentimentos fortes e aversivos. O contato com esses sentimentos pode ajudar no início do processo de quebra de suas próprias anestesias relacionais e da tendência de alguns homens em repremir os seus sentimentos (Ravazzola, 1997, 1998, 2015)

A comparação entre as semelhanças e diferenças das histórias pessoais e a do livro foi uma oportunidade de estimular que os participantes trouxessem à tona as principais questões que favorecem a naturalização da violência em suas relações. Esse processo de reflexão indireta permitiu a manifestação de mecanismos de negação, minimização, externalização da responsabilidade dos homens autores de violência.

A maioria dos homens apresentou respostas que apontaram as próprias vivências como menos graves que a história do livro. Os homens mantiveram a tendência de naturalizar a violência ao comparar as suas histórias com os personagens do livro. Eles não reconheceram toda magnitude do impacto da violência às próprias parceiras e a si mesmo. Eles tiveram mais facilidade em identificar os prejuízos causados à outra mulher - no caso, a personagem Roz.

Os aspectos que os homens reconheceram como semelhantes foram relacionados às respostas dispostas em quatro categorias: desresponsabilização; minimização, negação da violência e início do processo de reconhecimento da violência. Na segunda etapa, 14 participantes se desresponsabilizaram, 14 minimizaram e 16 negaram a violência ao identificar em suas histórias pelo menos um aspecto semelhante à dinâmica apresentada no livro. Apenas quatro homens na segunda etapa trouxeram elementos que demonstravam algum reconhecimento de sua corresponsabilidade. A soma de elementos em cada categoria ultrapassa a quantidade de participantes, pois muitos deles citaram mais de um elemento de sua vivência como semelhante à história do livro. Muitos elementos citados pelo mesmo participante perpassaram mais de uma categoria.

Alguns homens perceberam a violência apenas como meros conflitos na relação, banalizando o seu impacto. Esses participantes relataram termos como "brigas", "erros", “incompreensões”, “poder”, "mentiras”, “xingamentos”, “discussões”, "palavras pesadas”, apenas um participante mencionou a palavra "violência". Essa situação pode indicar uma dificuldade em nomear a violência conjugal e uma tendência a minimizá-la (Angelim, 2009; Diniz \& Pondaag, 2004, 2006; Guimarães, 2009; Pondaag, 2003, 2009; Silveira et al., 2009; Toneli et al., 2010).

As respostas dos participantes sobre as diferenças de suas histórias com a dos personagens do livro baseou-se em comparações sobre o que foi melhor ou pior em cada vivência. A grande maioria dos homens trouxe respostas que apontaram as próprias vivências como menos graves que a 
história do livro, se desresponsabilizaram pelas agressões ou negaram a violência. Ao todo, 38 homens apresentaram comparações nesse sentido na segunda etapa.

A maioria desses participantes relacionou a ocorrência de agressões mais brandas ou a não existência de traições, mentiras e enganações, revelando a tendência de minimização da violência por 20 homens na segunda etapa. Outros 11 homens negaram totalmente qualquer semelhança. Seis participantes apresentaram uma tendência a se desresponsabilizar. Por último, sete participantes conseguiram descrever respostas que indicaram alguma reflexão sobre a sua responsabilização das agressões ao relatar a diferença entre suas histórias pessoais e a do livro.

As respostas dos homens mostraram um continuum de naturalização da violência ao comparar as vivências pessoais com a história do livro. Alguns homens não conseguiram perceber nenhum aspecto da violência em suas relações, negaram totalmente as agressões. Outros homens conseguiram perceber algum aspecto da violência, mas tiveram a tendência de minimizá-la perceberam, mas a banalizaram. Outros se desresponsabilizaram, ou seja, compreenderam que o relacionamento não estava bem ou até mesmo que tinha violência, mas justificaram as agressões e/ou externalizaram a sua responsabilidade para a parceira ou para outros eventos. Ou seja, alguns negaram totalmente, outros perceberam e minimizaram o seu impacto, outros compreenderam sua existência, mas não perceberam como sua responsabilidade. O livro pode ter ajudado na manifestação de mecanismos de naturalização da violência por meio da identificação inicial com os personagens do livro ou mesmo quando não houve identificação alguma, como no caso da negação.

A conscientização da violência é um dos primeiros passos necessários para a sua superação. Mesmo que os participantes não percebam toda a dimensão da violência em suas relações conjugais, a manifestação de alguns aspectos de sua naturalização tais como o abuso de álcool, o ciclo da violência e as brigas e erros na dinâmica conjugal pode contribuir para que os participantes possam trabalhar a ressignificação desses elementos na continuidade do acompanhamento psicossocial para que, futuramente, possam iniciar o processo de reflexão sobre os diversos problemas psicossociais e de saúde que afetam as mulheres vítimas e os homens autores devido às agressões, mesmo que de diferentes modos (Alvarenga, 2012; Araujo, 2012; Couto \& Schraiber, 2005; Medeiros, 2010; Oliveira, 2015; Oliveira \& Gomes, 2011; Randle \& Graham, 2011).

As anestesias que os participantes da primeira etapa mais se identificaram foram: "Onde foi que eu errei?”, “Quem disse que a vida é fácil?”, "Ele jura que não vai acontecer de novo...” e “Talvez ele melhore...". Dentre as 35 anestesias listadas no livro, 33 foram marcadas pelo menos uma vez. Os participantes conseguiram identificar 19 anestesias relacionais em suas próprias vivências sem os estímulos das anestesias do livro. 
Na segunda etapa, dentre as 31 anestesias listadas no questionário criado a partir dos dados da primeira etapa, 30 foram marcadas pelo menos uma vez. Uma anestesia foi citada por mais da metade dos 45 participantes: "Ela não precisava chamar a polícia". Outras seis foram mencionadas por mais de um terço dos homens: "Eu te amo... Nunca quis magoar você..."; "Eu não vou perder minha família"; "Eu ainda gosto dela"; "Não vai acontecer de novo... Eu juro!"; "Pense nas crianças."; "Não jogue fora nosso amor.”, o que indica um alto reconhecimento de sua influência na manutenção da violência conjugal pelos homens autores de violência da segunda etapa. Foram criadas quatro categorias de anestesias que os próprios homens autores de violência criaram e/ou consideraram como mais influentes e impactantes em suas vivências: Desresponsabilização do homem; Minimização da violência; Negação da violência; e Início do processo de reconhecimento da violência/responsabilização.

O processo de construção de anestesias ocorre de forma sistêmica, com influência de questões sociais e culturais sobre a dinâmica familiar e conjugal. A sua ressignificação também é complexa e exige recursos criativos e diferenciados para intervir com os homens autores. A estratégia metodológica proposta nesse estudo pretende ser mais uma opção para ampliar os recursos para identificar anestesias desses homens. O diferencial dessa pesquisa foi ajudar na identificação, nomeação e reflexão sobre as anestesias por parte dos próprios homens autores e não apenas pelos/as profissionais. Esse processo de reflexão ocorreu gradualmente em várias etapas. Essa aproximação gradativa ajudou os participantes a irem reconhecendo e lidando com seus sentimentos.

A nomeação/intitulação da própria história pelos homens revelou paradoxos da presença da violência na relação de muitos participantes. A partir da análise dos títulos foram identificadas quatro categorias de paradoxos entre o discurso de naturalização da violência e a presença de agressões na relação: desresponsabilização dos homens; minimização; negação; início do processo de reconhecimento da violência.

O método proposto ajudou a iniciar a quebra da terceira condição de duplo-vínculo (Angelim, 2009; Angelim \& Diniz, 2010), pois contribuiu para que esses participantes manifestassem contradições e paradoxos de suas respostas. Essa manifestação pode abrir possibilidade para reflexão sobre vários aspectos da relação conjugal e de sua vida, inclusive sobre possíveis prejuízos de seguir um padrão de masculinidade hegemônico, que ainda impõe diversos duplo-vínculos aos homens atualmente.

A estratégia metodológica utilizada permitiu a alguns participantes iniciarem o processo de reflexão acerca das mensagens paradoxais e desafiar/rever o valor de sobrevivência preconizado na relação. Esse recurso auxilia, então, as pessoas envolvidas a questionarem a primeira e a segunda 
condição do duplo-vínculo (Angelim \& Diniz, 2010). A estratégia utilizada pode fornecer subsídios importantes para uma posterior intervenção com homens e mulheres. A partir dos mecanismos de naturalização evidenciados pelos participantes nos títulos de suas próprias vivências, os profissionais podem ter elementos que possibilitem a quebra da terceira condição de duplo-vínculo: a impossibilidade de sair e/ou de refletir sobre a relação.

A palavra "mas" - do item oito do questionário - permitiu confrontar diretamente suas anestesias relacionais (Ravazzola, 1997). Os participantes manifestaram paradoxos entre o amor que sente, sentia ou esperava que a ex/parceira sentisse e a violência que ele mesmo pratica ou praticava (Angelim \& Diniz, 2010). O exercício de dar continuidade ao título do livro pode ajudálos a se posicionaram acerca da existência desse paradoxo que também lhes aprisionam à dinâmica marcada pela violência.

Investimos na construção de uma proposta metodológica criativa e mais atrativa aos homens, para escutá-los de forma diferenciada e não apenas responsabilizá-los (Lima \& Büchele, 2011). Essa escuta incluiu várias dimensões que transcenderam a dimensão individual e contemplou aspectos sociais e culturais da violência (Medrado, 2010; Medrado \& Lyra, 2008). Consideramos ser de fundamental importância ajudar esses homens a repensar a relação entre violência, masculinidades e conjugalidades como um dos passos rumo a relações mais igualitárias em suas relações conjugais.

Nós consideramos a importância de destacar e refletir também sobre as anestesias relacionais e os aspectos duplo-vinculares dos homens e das mulheres em conjunto diante do aspecto complementar dos inúmeros processos que compõem as tramas das dinâmicas conjugais em situação de violência. Nós incluímos cinco mulheres que eram parceiras ou ex-parceiras dos homens participantes e que também compareceram ao Grupo Misto e preencheram os questionários.

Os resultados das respostas de homens e mulheres apresentados em conjunto permitem perceber que elas se complementaram sobre a percepção da dinâmica conjugal do livro. As participantes também apresentaram sentimentos fortes e aversivos em relação à situação de violência do casal protagonista.

A reflexão sobre as respostas dos homens e mulheres ao compararem as suas vivências com a história dos personagens do livro têm o potencial de considerar e enfatizar a variabilidade das conjugalidades. Entendemos que o reconhecimento dessa diversidade pelos profissionais facilita a escuta desses/as homens e mulheres como seres humanos, não apenas como meros agressores e vítimas. A superação dessa cristalização e rotulação das pessoas envolvidas na violência conjugal é fundamental para uma intervenção adequada a esses casos. Dessa forma, os profissionais podem acreditar, priorizar e investir mais na possibilidade de superação da violência e de mudança das 
masculinidades, feminilidades e conjugalidades. Essa visão mais ampla possibilita também abranger esses homens e essas mulheres como os/as principais agentes de mudanças para a superação e transformação de sua própria relação conjugal (Beiras \& Cantera, 2012; Separavich \& Canesqui, 2013).

A aplicação da Teoria do Duplo-Vínculo - TDV e das anestesias relacionais revelam que o ponto central do aprisionamento de homens e mulheres à dinâmica marcada pela violência é o impedimento ou redução significativa da capacidade de reconhecer, expressar e refletir sobre os sentimentos, as crenças e os pensamentos sobre a relação e a violência. Contribuímos nesse estudo para promover a manifestação de alguns aspectos que aprisionam homens diante de paradoxos impostos desde a socialização masculina e que repercutem em suas conjugalidades. Entendemos que a retomada da capacidade de refletir é imprescindível para libertar os homens de várias vulnerabilidades presentes nas relações sociais e conjugais nocivas aos homens e às mulheres.

Criamos e oferecemos nesse estudo um instrumento simples, intenso e de grande impacto emocional para ajudar os próprios homens a manifestarem e, até mesmo, perceberem aspectos que lhe aprisionam a essas relações. Acreditamos que essa estratégia pode ser um passo inicial e valioso para diversos homens em um longo processo posterior de mudanças e transformações para superação da violência conjugal.

Toda proposta metodológica possui limitações. O sucesso dessa pesquisa-intervenção depende da leitura de um livro, do preenchimento de um questionário e da potencialidade que esses processos trazem de evocar reflexões acerca das identidades de gênero, dos mitos e prescrições sociais e suas consequências para as pessoas e para as relações. Identificamos, assim, três limitações principais dessa estratégia. A primeira está na exigência da capacidade de leitura e escrita por parte dos participantes. Essa exigência pode ser um empecilho em contextos de pobreza e/ou de baixa escolaridade. A segunda limitação consiste em não ter como garantir plenamente que os participantes de fato leiam o livro durante a semana, em que tentamos contorná-la na segunda etapa da pesquisa, ao realizar a leitura durante o grupo. A terceira refere-se às pessoas que coordenam a pesquisa/intervenção, pois elas precisam estar cientes de seus próprios mitos acerca da masculinidade e feminilidade; precisam ter discernimentos para promover e ampliar a reflexão acerca da construção das identidades masculinas e femininas, das dinâmicas relacionais e os impactos das violências em todas as pessoas envolvidas na conjugalidade.

Outras limitações referem-se à pouca quantidade de participantes desse estudo; ao fato de ter sido realizado apenas com homens autores de um estado brasileiro; e por não ter ocorrido um treinamento prévio para os/as profissionais do SERAV e NAFAVD que auxiliaram a coleta de dados - especialmente sobre questões de masculinidades, violência e conjugalidades. 
Essas limitações podem ser contornadas. Os/as profissionais podem incentivar os homens a pedirem para algum familiar ou amigo/a que leia o livro para ele. A história pode também ser lida em grupo e a pessoa que não sabe ler, pode acompanhar a leitura através das ilustrações. Para contornar a dificuldade de escrita de alguns participantes, os/as profissionais podem utilizar o questionário construído apenas no segundo encontro. Nesse caso, a estratégia seria gravar o encontro grupal no qual as perguntas seriam feitas e respondidas oralmente.

As pessoas que não leram o livro podem ser convidadas a participarem da discussão em outro encontro grupal. Uma alternativa possível é solicitar que essas pessoas observem o encontro de discussão sobre o livro e sejam estimuladas a fazer a leitura e preenchimento do questionário posteriormente. Essa última alternativa não é recomendada para contextos de pesquisas, sugerimos sua aplicação apenas como método de intervenção para não contaminar os resultados de um possível estudo. Acreditamos que podemos encontrar diversas formas criativas para superar essas e outras dificuldades que certamente possam surgir a partir do uso dessa estratégia. Fica o desafio de rever e aprimorar as limitações de modo a ampliar os benefícios dessa proposta de pesquisa e intervenção.

O aprimoramento dessa proposta de pesquisa e intervenção merece atenção. Fica aqui o incentivo para que outras pesquisas sejam realizadas no intuito de testar, ampliar, questionar, remodelar e reforçar essa estratégia metodológica. Outras pesquisas podem ser delineadas, por exemplo, para aplicar esse método em grupo controle composto por homens autores de violência conjugal que não estão no contexto da Justiça. Os resultados podem ser comparados para analisar as semelhanças e diferenças na capacidade de refletir e nomear a violência, o progresso no acompanhamento psicossocial e, inclusive, a aceitação ou recusa de encaminhamentos.

Outra amostra pode ser composta por homens da comunidade que supostamente não cometem ou cometeram violência conjugal contra suas ex/parceiras. Os resultados podem ajudar a verificar se há diferenças e semelhanças nas concepções sobre violência, conjugalidade e masculinidades entre os homens autores e os homens em geral. Essa proposta pode ser utilizada com homens jovens e adolescentes em escolas e universidades para promover a prevenção da violência.

Uma adaptação desse método também pode ser realizada para uma aplicação a nível nacional em diferentes contextos (judicial, saúde, assistência social, comunidades etc.). A ampliação da amostra que inclua homens de outros estados ou regiões do Brasil poderia consolidar um maior conhecimento obtido pelos próprios homens brasileiros de suas anestesias relacionais e os paradoxos da relação que dificultam ou impedem o reconhecimento da violência nas diferentes conjugalidades. 
A ampliação da amostra e adaptação de outras estratégias metodológicas podem fornecer subsídios para futuramente elaborar um livro em formato de história em quadrinhos baseado na visão dos próprios homens. A partir de uma história escrita por uma mulher, podemos elaborar um livro narrado e ilustrado pelos homens autores de violência conjugal.

As limitações do estudo somadas à necessidade de outras pesquisas não tiram o mérito da estratégia metodológica proposta. Essa estratégia mostrou seu potencial e utilidade como método de pesquisa e como meio importante de intervenção. Esperamos que sua utilização em diferentes contextos e o consequente aprimoramento dessa proposta de intervenção por outros pesquisadores e/ou profissionais possam ajudar outros homens a darem os primeiros passos rumo a sua libertação da dinâmica permeada violência conjugal.

Acreditamos que a leitura do livro, o preenchimento do questionário e a reflexão em grupo, somados, têm o potencial de iniciar o processo de reconhecimento da violência pelos homens autores. Esse processo é fundamental para a responsabilização da violência cometida, para que eles não se deixarem levar cegamente por suas próprias percepções permeadas pela naturalização da violência por meio de falas-armadilhas: "Ela não precisava chamar a polícia". Esperamos que essa estratégia ajude-os a se tornarem capazes de se ouvirem e levarem a sério os riscos do relacionamento para as mulheres e para si mesmos.

O título dessa tese foi baseado em uma dessas percepções armadilhas baseadas na negação da violência pelo participante. Essa compreensão dificulta a percepção da violência e facilita o processo de naturalização das agressões no espaço privado, pois contribui também para que homens considerem desnecessária a busca da Justiça ou de terceiros por parte da mulher. Muitos homens percebem a denúncia das mulheres como algo desnecessário por considerarem que não houve violência. Geralmente, eles não conseguem perceber a violência sofrida pelas ex/companheiras e não compreendem a denúncia como um meio para elas buscarem e receberem apoio e proteção (Maciel \& Barbosa, 2010; Silveira et al., 2009).

Homens podem ter dificuldade de perceber que os privilégios sociais das masculinidades podem resultar paradoxalmente no próprio aprisionamento dos mesmos à dinâmica marcada pela violência. A revisão de anestesias e paradoxos da relação que naturalizam a violência pode ajudálos a desconstruir os mecanismos de negação, de minimização e desresponsabilização das agressões. Essa revisão pode configurar como um primeiro passo para que eles mesmos possam superar a violência e verificar os benefícios da igualdade de direitos na relação conjugal.

A atenção direcionada a homens autores é fundamental pelo fato de a violência conjugal surgir, em muitos casos, como uma possibilidade de demonstração de poder e de virilidade, justamente quando muitos homens sentem que estão desempoderados (Zuma et al., 2013). 
Entendemos que é importante intervir com esses homens para que eles mesmos consigam perceber os prejuízos da socialização machista para homens e mulheres, para compreenderem os impactos de diversos mitos sociais na construção identitária de homens - especialmente pelos mitos que constroem a masculinidade hegemônica. Os mitos dificultam os questionamentos e reflexões sobre mandatos sociais e discursos sobre as masculinidades que favorecem a instalação e manutenção da violência conjugal.

A intervenção com homens autores deve ser em conjunto com o processo de empoderamento de mulheres e em consonância com as ideologias dos movimentos feministas. A violência conjugal poderá ser prevenida ou combatida por meio do aumento da capacidade dos indivíduos em questionar e ressignificar mandatos tradicionais das masculinidades e das feminilidades (Beiras et al., 2012).

As ações com homens autores de violência conjugal contra mulheres podem favorecer processos de empoderamentos humanos como proposta de compreensão e intervenção da violência. Essas ações podem abranger tentativas de criações e fortalecimentos de pontes de transformação do indivíduo (Ponce-Antezana, 2012). A promoção de empoderamentos e mudanças subjetivas pode ser, inclusive, um dos meios mais efetivos para a responsabilização de homens autores de violência (Beiras et al., 2012).

A intervenção com homens autores é importante para ajudá-los a iniciar o processo de autocuidado, de autorresponsabilização e de conscientização das anestesias, das contradições e dos paradoxos da dinâmica relacional marcada e estruturada pela violência. Esse é um passo estratégico, fundamental e central para a superação da violência de gênero contra a mulher nas relações conjugais. 


\section{Referências Bibliográficas}

Acosta, F., Andrade, A. F., Bronz, A. (2004). Conversas Homem a Homem: Grupo Reflexivo de Gênero. Metodologia. Rio de Janeiro: Instituto Noos. Recuperado em 5 de maio de 2015, de http://www.noos.org.br/userfiles/file/metodologia_port.pdf

Acselrad, G., Karam, M. L., David, H. M. S. L., \& Alarcon, S. (2012). Consumo de bebidas alcoólicas no Brasil: estudo com base em fontes secundárias. Rio de Janeiro: FLACSO Brasil.

Aguiar, L. H. M. (2009). Gênero e masculinidades: follow-up de uma intervenção com homens autores de violência conjugal. Dissertação de Mestrado, Instituto de Psicologia, Universidade de Brasília, Brasília.

Akoensi, T. D., Koehler, J. A., Lösel, F., \& Humphreys, D. K. (2013). Domestic Violence Perpetrator Programs in Europe, Part II: A Systematic Review of the State of Evidence. International Journal of Offender Therapy and Comparative Criminology, 57(10). Recuperado em 24 de maio de 2015, de http://ijo.sagepub.com/content/57/10/1206.long

Almeida, M. V. (1996). Gênero, masculinidade e poder: revendo um caso do sul de Portugal. Anuário Antropológico. 95, 161-189. Recuperado em 11 de maio de 2015, de http://miguelvaledealmeida.net/wp-content/uploads/2008/06/genero-masculinidade-epoder.pdf

Alvarenga, A. L. (2012). A Lei da Palmada e abuso físico intrafamiliar: reflexões sobre a punição corporal como prática educativa. Trabalho de Conclusão de Curso, Pós-Graduação em Psicologia Jurídica, Instituto de Educação Superior de Brasília - IESB, Brasília.

Alves, R. A., Pinto, L. M. N., Silveira, A. M., Oliveira, G. L., \& Melo, E. M. (2012). Homens, vítimas e autores de violência: a corrosão do espaço público e a perda da condição humana. Interface - Comunicação, Saúde, Educação, 16(43), 871-883. Recuperado em 12 de abril de 2015, de http://www.scielo.br/pdf/icse/v16n43/aop5212.pdf

Alves, S. L. B. \& Diniz, N. M. F. (2005). Eu digo não, ela diz sim: a violência conjugal no discurso masculino. Revista Brasileira de Enfermagem, Brasília, 58(4), 387-392. Recuperado em 1 de agosto de 2008, de http://www.scielo.br/pdf/reben/v58n4/a02v58n4.pdf

Anacleto, M. I. C. (2000). Terapia familiar: elos entre as concepções analíticas e sistêmicas. Revista da SPAGESP, 1(1), 43-48. Recuperado em 10 de junho de 2015, de http://pepsic.bvsalud.org/scielo.php?pid=S1670007\&script=sci_arttext

Angelim, F. P. (2004). Construindo novos discursos sobre a violência doméstica: uma articulação entre a Psicologia Clínica e a Justiça. Dissertação de Mestrado, Instituto de Psicologia, Universidade de Brasília.

Angelim, F. P. (2009). Mulheres vítimas de violência: Dilemas entre a busca da intervenção do Estado e a tomada de consciência. Tese de doutorado. Instituto de Psicologia, Universidade de Brasília, Brasília.

Angelim, F. P., \& Diniz, G. R. S. (2010). A Teoria do Duplo-Vínculo como referencial teórico para intervenções em casos de violência contra mulheres. In I. Ghesti-Galvão \& E. C. B. Roque (Orgs.). Aplicação da lei em uma perspectiva interprofissional: Direito, psicologia, psiquiatria, serviço social e ciências sociais na prática jurisdicional (pp. 397-412). Brasília: Editora Lumen Juris.

Anistia Internacional - AI (2014). Campanha Jovem Negro Vivo. Recuperado em 7 de maio de 2015, de https://anistia.org.br/campanhas/jovemnegrovivo/

Araújo, K. S. (2012). Violência conjugal, masculinidades e intervenção psicossocial: análise das percepções de profissionais. Trabalho de Conclusão de Curso, Pós-Graduação em Psicologia Jurídica, Instituto de Educação Superior de Brasília - IESB, Brasília.

Ávila, T. A. P., Machado, B. A., Suxberger, A. H. G., \& Távora, M. F. (2014). Modelos europeus de enfrentamento à violência de gênero: experiências e representações sociais. Brasília: ESMPU. 
Azevedo, R. G. (2008). Sistema penal e violência de gênero: análise sociojurídica da Lei 11.340/06. Sociedade e Estado,23(1), 113-135. Recuperado em 29 de maio de 2015, de http://www.scielo.br/pdf/se/v23n1/a05v23n1.pdf

Banco Mundial/CEPIA (2003). A questão de gênero no Brasil. Brasília: Banco Mundial/ CEPIA.

Bandeira, L. (2009). Três décadas de resistência feminista contra o sexismo e a violência feminina no Brasil: 1976 a 2006. Sociedade e Estado, Brasília, 24(2), 401-438. Recuperado em 19 de maio de 2015, de www.scielo.br/pdf/se/v24n2/04.pdf

Bardin, L. (2004). Análise de Conteúdo. (3 $3^{\mathrm{a}}$ ed). Lisboa: Edições 70.

Barker, G., \& Nascimento, M. (2001). Da violência para convivência. Caderno 3 da Série "Programa H - Trabalhando com homens jovens". Rio de Janeiro: Instituto Promundo. Recuperado em 14 de junho de 2015, de http://promundo.org.br/wpcontent/uploads/2014/12/Programa-H-Trabalhando-com-Homens-Jovens.pdf

Bauer, M. W. (2002). Análise de conteúdo clássica: uma revisão. In M. W. Bauer \& G. Gaskell (Orgs.). Pesquisa qualitativa com texto, imagem e som: um manual prático (pp. 189-217) (9a ed). Petrópolis: Vozes, 2007.

Beauvoir, S. (1967) O segundo sexo: a experiência vivida. (2a ed.). São Paulo: Difusão.

Beauvoir, S. (2000). O segundo sexo, vol. 1. Rio de Janeiro: Nova Fronteira, 10a Edição. (Original publicado em 1946).

Beiras, A. (2012). La (de)construcción de subjetividades en un grupo terapéutico para hombres autores de violencia en sus relaciones afectivas. Tesis Doctoral. Departamento de Psicología Social. Universitat Autònoma de Barcelona.

Beiras, A. (2014). Relatório Mapeamento de Serviços de atenção grupal a homens autores de violência contra mulheres no contexto brasileiro. Rio de Janeiro: Instituto NOOS. Recuperado em 3 de maio de 2015, de http://www.noos.org.br/userfiles/file/Relat\%C3\%B3rio\%20Mapeamento\%20SHAV_site.pd $\underline{f}$

Beiras, A., \& Cantera, L. (2012). Narrativas personales, construcción de masculinidades aportaciones para la atención psicosocial. PSICO, Porto Alegre, PUCRS, 43(2), 251-259. $\begin{array}{lllll}\text { Recuperado em } & 22 \text { de }\end{array}$ http://www.revistaseletronicas.pucrs.br/ojs/index.php/revistapsico/article/viewFile/10023/80 $\underline{35}$

Beiras, A., Moraes, M., Alencar-Rodrigues, R., \& Cantera, L. M. (2012). Políticas e leis sobre violência de gênero - reflexões críticas. Psicologia \& Sociedade, 24(1), 36-45. Recuperado em 22 de abril de 2015, de http://www.scielo.br/pdf/psoc/v24n1/05.pdf

Berceli, D. (2007). Evaluating the Effects of Stress Reduction Exercises. Tese de doutorado, Arizona State University, Arizona.

Berceli, D. (2010). Exercícios para liberação do trauma. Recife: Libertas Editora.

Blay, E. V. (2014). Feminismos e masculinidades: novos caminhos para enfrentar a violência contra a mulher. São Paulo: Cultura Acadêmica.

Bourdieu, P. (1999). A dominação masculina. Rio de Janeiro: Bertrand Brasil. (Original publicado em 1998).

Boyd-Franklin, N., \& Franklin, A. J. (2003). Casais afro-americanos em terapia. In M. McGoldrick (Org.), Novas Abordagens da Terapia Familiar: Raça, Cultura e Gênero na prática clínica (pp. 309-323). São Paulo: Roca.

Braga, K. S., Nascimento, E. [Orgs]; Diniz, D. [Ed.] (2006). Bibliografia Maria da Penha: Violência contra a mulher no Brasil: 1980-2006. Brasília: LetrasLivres/Editora UnB.

Braga, L. J., Sosa, M. E., \& Nogueira, R. M. (2004). 8 jeitos de mudar o mundo na escola. São Paulo: Fundação Educar Dpaschoal. Recuperado em 20 de maio de 2015, de http://unesdoc.unesco.org/images/0013/001394/139486porb.pdf

Brah, A. (2006). Diferença, diversidade, diferenciação. Cadernos Pagú, 26, 329-376. Recuperado em 10 de junho de 2015, de http://www.scielo.br/pdf/cpa/n26/30396.pdf 
Brancalhone, P. G., Fogo, J. C. \& Williams, L. C. A. (2004). Crianças expostas à violência conjugal: avaliação do desempenho acadêmico. Psicologia: Teoria e Pesquisa, Brasília, 20(2), 113-117.

Brasil (2006). Lei 11.340 de 07/08/2006 - "Lei Maria da Penha”. Recuperado em 28 de março de 2007, de http://www.planalto.gov.br/ccivil/_Ato2004-2006/2006/Lei/L11340.htm

Brasil (2015). Lei 13.104/15 - "Lei do Feminicídio". Recuperado em 19 de maio de 2015, de http://www.planalto.gov.br/ccivil_03/_Ato2015-2018/2015/Lei/L13104.htm

Brasil. Ministério da Saúde. (2008). Política nacional de atenção integral à saúde do homem: princípios e diretrizes - PNAISH. Brasília: Ministério da Saúde.

Brasil. Presidência da República. Secretaria Especial de Políticas para as Mulheres - SPM (2004). Plano Nacional de Políticas para as Mulheres. Brasília: Secretaria Especial de Políticas para as Mulheres. Recuperado em 20 de agosto de 2009, de http://200.130.7.5/spmu/docs/PNPM.pdf

Brasil. Presidência da República. Secretaria Especial de Políticas para as Mulheres - SPM (2008). II Plano Nacional de Políticas para as Mulheres. Brasília: Secretaria Especial de Políticas para as Mulheres. Recuperado em 20 de agosto de 2009, de http://200.130.7.5/spmu/docs/Livro_II_PNPM_completo08.10.08.pdf

Brasil. Presidência da República. Secretaria Especial de Políticas para as Mulheres - SPM (2013). Matéria: Governo federal investirá $R \$ 265$ milhões em serviços integrados de atendimento à mulher em situação de violência. Brasília: Secretaria Especial de Políticas para as Mulheres. Recuperado em 5 de abril de 2013. de http://spm.gov.br/noticias/ultimas_noticias/2013/03/13-03-governo-federal-investira-r-265milhoes-em-servicos-integrados-de-atendimento-a-mulher-em-situacao-de-violencia

Brasil. Presidência da República. Secretaria Especial de Políticas para as Mulheres - SPM (2008). Diretrizes para Implementação dos Serviços de Responsabilização e Educação dos Agressores. Brasília: SPM. Recuperado em 16 de abril de 2015, de http://www.spm.gov.br/sobre/a-secretaria/subsecretaria-de-enfrentamento-a-violenciacontra-as-mulheres/pacto/servico-de-responsabilizacao-do-agressor-pos-workshop.pdf

Brauner, M. C. C. \& Carlos, P. P. (2004). A violência intrafamiliar sob a perspectiva dos direitos humanos. In G. Maluschke, J. S. F. N. Bucher-Maluschke \& K. Hermanns (Orgs.), Direitos humanos e violência: desafios da ciência e da prática (pp. 133-147). Fortaleza: Fundaçao Konrad Adenauer.

Buompadre, J. E. (2013). Violencia de género, femicidio y derecho penal: Los nuevos delitos de género. Córdoba: Alveroni Ediciones.

Butler, J. (2003). Problemas de gênero: feminismo e subversão da Identidade. Rio de Janeiro: Civilização Brasileira.

Camargo, B. V., Campos, P. H. F., Torres, T. L., Stuhler, G. D., \& Matão, M. E. L. (2011). Representações sociais de saúde e cuidado: um estudo multicêntrico sobre vulnerabilidade masculina. Temas em Psicologia, 19(1), 179-192. Recuperado em 11 de maio de 2015, de http://pepsic.bvsalud.org/scielo.php?script=sci_arttext\&pid=S1413$\underline{389 X 2011000100014 \& \operatorname{lng}=\mathrm{pt} \& \ln \mathrm{g}=\mathrm{pt}}$

Cantera, L. M. (2007). Casais e violência: um enfoque além do gênero. Porto Alegre: Dom Quixote.

Carreira, D. \& Pandjiarjian, V. (2003). Vem pra roda! Vem pra rede! Guia de apoio à construção de redes de serviços para o enfrentamento da violência contra mulher. São Paulo: Rede Mulher de Educação. Recuperado em 1 de agosto de 2008, de http://www.redemulher.org.br/publicacoes/vempraroda.pdf

Carvalho, M. P. F. S. (2010). A Crítica de Judith Butler às Normas que Governam Gênero e Sexualidade. Ethica. 17(2), 81-92. 
Cerqueira, D., Matos, M., Martins, A. P. A., \& Pinto Júnior, J. (2015). Avaliando a efetividade da Lei Maria da Penha. Brasília: IPEA. Recuperado em 19 de maio de 2015, de http://www.ipea.gov.br/portal/images/stories/PDFs/TDs/td_2048k.pdf

CFEMEA (2009). Lei Maria da Penha: do papel para a vida. Comentários à Lei 11.340/2006 e sua inclusão no ciclo orçamentário. ( $2^{\mathrm{a}}$ edição). Brasília: CFEMEA. Recuperado em 1 de agosto de

2011,

de

http://www.andi.org.br/sites/default/files/legislacao/leimariadapenhadopapelparaavida_2edic ao\%5B1\%5D.pdf

Chaves, D. S., \& Silva, M. M. B. L. (2010). Não vou fazer amor por fazer: Grupo Psicossocial Misto no Contexto da Justiça, um espaço para transcender as dicotomias de gênero. In I. Ghesti-Galvão \& E. C. B. Roque (Orgs.), Aplicação da lei em uma perspectiva interprofissional: Direito, psicologia, psiquiatria, serviço social e ciências sociais na prática jurisdicional (pp. 413-426). Brasília: Editora Lumen Juris.

Connell, R. W. (1995). Políticas da masculinidade. Educação e Realidade, Porto Alegre, 20(2), 185-206.

Connell, R. W. (1997). La organización social de la masculinidad. In T. Valdés \& J. Olavarría (Orgs.). Masculinidad/es: poder y crisis (p. 31-48). Santiago: Ediciones de las mujeres.

Conselho Federal de Psicologia - CFP (2000). Resolução CFP 016/2000, de 20 de dezembro de 2000, dispõe sobre a realização de pesquisa em psicologia com seres humanos. Recuperado $\begin{array}{llllll}\text { em } & 8 & \text { de } & \text { agosto } & \text { de } & 2008,\end{array}$ http://www.pol.org.br/pol/export/sites/default/pol/legislacao/legislacaoDocumentos/resoluca o2000_16.pdf

Conselho Nacional de Justiça - CNJ (2010). Manual de Rotinas e Estruturação dos Juizados de Violência Doméstica e Familiar Contra a Mulher. Brasília: Conselho Nacional de Justiça. Recuperado em 25 de julho de 2011, de http://www.cnj.jus.br/images/programas/mutiroesda-cidadania/manualmariadapenha.pdf

Conselho Nacional de Justiça - CNJ (2011). Resolução $n^{\circ}$ 128, de 17 de março de 2011. Brasília: CNJ.

Conselho Nacional de Saúde - CNS (1996). Resolução 196/96 sobre as normas e diretrizes regulamentadoras de pesquisa envolvendo seres humanos. Recuperado em 8 de agosto de 2008, de http://www.unb.br/fs/clm/labcor/etic196.htm

Costa, P. R. S. M., \& Grossi, M. P. (2010). Violências de gênero: assassinos/as impiedosos/as ou enlouquecidos/as pela dor do amor? Estudos Feministas, Florianópolis, 18(2), 607-623. Recuperado em 19 de maio de 2015, de http://www.scielo.br/pdf/ref/v18n2/22.pdf

CPMIVCM (2013). Relatório final da CPMI da Violência contra Mulher. Brasília: Senado Federal. $\begin{array}{llllll}\text { Recuperado em } 27 \text { de julho de } & \end{array}$ http://www.senado.gov.br/atividade/materia/getPDF.asp?t=124181\&tp=1

Cronen, V. E., Johnson, K. M., \& Lannamann, J. W. (1982). Paradoxes, Double Binds and Reflexive Loops: An Alternative Theoretical Perspective. Family Process, 21(1), 91-112. Recuperado em 6 de maio de 2015, de http://onlinelibrary.wiley.com/doi/10.1111/j.15455300.1982.00091.x/pdf

Cunha, T. R. A. (2008). Violência conjugal: os ricos também batem. Publicatio UEPG, Ponta Grossa, 16(1), 167-176. Recuperado em 1 de setembro de 2009, de http://www.revistas2.uepg.br/index.php/humanas/article/viewFile/628/616

Dantas-Berger, S. M., \& Giffin, K. (2005). A violência nas relações de conjugalidade: invisibilidade e banalização da violência sexual?. Cad. Saúde Pública, 21(2), 417-425. Recuperado em 1 de agosto de 2008, de http://www.scielo.br/pdf/csp/v21n2/08.pdf

Day, V. P., Telles, L. E. B., Zoratto, P. H., Azambuja, M. R. F., Machado, D. A., \& Silveira, M. B. (2003). Violência doméstica e suas diferentes manifestações. Revista de Psiquiatria do Rio Grande do Sul. 25(1), 9-21. Recuperado em 19 de maio de 2015, de www.scielo.br/pdf/rprs/v25s1/a03v25s1 
Debert, G. G. \& Gregori, M. F. (2008). Violência e gênero: novas propostas, velhos dilemas. Rev. bras. Ci. Soc.Fev, 23(66), 165-185. Recuperado em 1 de agosto de 2008, de http://www.scielo.br/pdf/rbcsoc/v23n66/11.pdf

Del Priori, M. (1993). Ao Sul do Corpo: condição feminina, maternidade e mentalidades no Brasil Colônia. Brasíli: Edunb; Rio de Janeiro: Editora José Olympio.

Diniz, G. R. S. (1999). Condição feminina: fator de risco para a saúde mental? In M. G. T. Paz \& A. Tamayo (Orgs.), Escola, saúde e trabalho: estudos psicológicos. Brasília: Editora UnB.

Diniz, G. R. S. (2003). Gênero e Psicologia: Questões Teóricas e Práticas. Revista Psicologia Brasil, 1(2), 16-21.

Diniz, G. R. S. (2011). Conjugalidade e violência: reflexões sob uma ótica de gênero. In T. FéresCarneiro (Org.), Casal e família: conjugalidade, parentalidade e psicoterapia (pp. 11-26). São Paulo: Casa do Psicólogo.

Diniz, G. R. S., \& Angelim, F. P. (2003). Violência doméstica: por que é tão difícil lidar com ela? Perfil e Vertentes, 15(1), 20 - 35.

Diniz, G. R. S., \& Pondaag, M. C. M. (2004). Explorando significados do silêncio e do segredo nos contextos de violência doméstica. In G. Maluschke, J. S. F. N. Bucher-Maluschke \& K. Hermanns, Direitos humanos e violência: desafios da ciência e da prática (pp. 133-147). Fortaleza: Fundaçao Konrad Adenauer.

Diniz, G. R. S., \& Pondaag, M. C. M. (2006). A face oculta da violência contra a mulher: o silêncio como estratégia de sobrevivência. In A. M. O. Almeida, M. F. S. Santos, G. R. S. Diniz \& Z. A.Trindade (Orgs.). Violência, Exclusão Social e Desenvolvimento Humano: Estudos em Representações Sociais. (pp. 233-259). Brasília: Editora Universidade de Brasília - EDUnB.

Distrito Federal (2013). NAFAVD já atenderam quase dez mil só neste ano, de www.mulher.df.gov.br/noticias/item/2389-nafavd-atenderam-quase-dez-mil-s\%C3\%B3neste-ano.html

Distrito Federal (2015). Secretaria Adjunta de Políticas para as Mulheres. Recuperado em 18 de agosto de 2015, http://www.uricer.edu.br/site/pdfs/perspectiva/136_314.pdf

Dohmen, M. L. (2006). Aspectos comportamentales. In J. Corsi (Org.). Violencia masculina en la pareja: una aproximación al diagnostico y a los modelos de intervención (pp.51-68). Buenos Aires: Paidós.

Dohmen, M. L. (2006a). Aspectos emocionales. In J. Corsi (Org.). Violencia masculina en la pareja: una aproximación al diagnostico y a los modelos de intervención (pp. 97-110). Buenos Aires: Paidós.

Fávero, M. H. (2010). Psicologia do Gênero: Psicobiografia, Sociocultura e Transformações. Curitiba: Ed. UFPR.

Feder, L., \& Wilson, D. B. (2005). A meta-analytic review of court-mandated batterer intervention programs: Can courts affect abusers' behavior? Journal of Experimental Criminology, 1: 239-262.

Feder, L., Wilson, D. B., \& Austin, S. (2008). Court-mandated interventions for individuals convicted of domestic violence. Campbell Systematic Reviews, 12, 1-46. Recuperado em 24 de maio de 2015, de http://campbellcollaboration.org/lib/download/218/

Figueira, K. T. S. (2011). O atendimento aos autores de violência conjugal contra a mulher: um estudo de caso. Trabalho de Conclusão de Curso, Instituto de Ciências Sociais, Universidade de Brasília, Brasília.

Foucault, M. (1996). Ordem do Discurso. São Paulo: Ed. Loyola.

Ghesti, I., Roque, E. C. B., \& Moura, M. L. R. (2006). Breve análise psicossocial dos casos inaugurais da $1^{\circ}$ Vara do Juizado de Violência Familiar e Doméstica contra a Mulher do TJDFT. In E. C. B. Roque, M. L. R. Moura, I. Ghesti (Orgs.). Novos paradigmas na Justiça Criminal: Relatos de experiências do Núcleo Psicossocial Forense do TJDFT. Brasília: TJDFT. Recuperado em 5 de agosto de 2008, de http://www.tjdft.jus.br/trib/publ/docPubl/edicoes/novosp.pdf 
Ghesti-Galvão, I., \& Roque, E. C. B. (2010). Aplicação da lei em uma perspectiva interprofissional: Direito, psicologia, psiquiatria, serviço social e ciências sociais na prática jurisdicional. Brasília: Editora Lumen Juris.

Ghesti-Galvão, I., Machado, J. P., \& Costa, M. M. O. (2010). Intervenções grupais e temáticas no contexto psicossocial-judiciário de enfrentamento da violência de gênero. In I. GhestiGalvão \& E. C. B. Roque. Aplicação da lei em uma perspectiva interprofissional: Direito, psicologia, psiquiatria, serviço social e ciências sociais na prática jurisdicional (pp. 427442). Brasília: Editora Lumen Juris.

Gomes, R. (2001). A análise de conteúdo em pesquisa qualitativa. In M. C. S. Minayo (Org.). Pesquisa social: teoria método e criatividade (pp. 79-108) (18 a ed.). Petrópolis: Vozes.

Gondolf, E. W. (2011). The weak evidence for batterer program alternatives. Aggression and Violent Behavior, 16, 347-353. Recuperado em 24 de maio de 2015, de http://www.sciencedirect.com/science/article/pii/S1359178911000632\#

Graham-Kevan, N. (2007). Domestic violence: research and implications for batterer programmes in Europe. Eur J Crim Policy Res (2007) 13:213-225. Recuperado em 24 de maio de 2015, de http://link.springer.com/article/10.1007\%2Fs10610-007-9045-4

Grandesso, M. (2001). Terapias pós-modernas: um panorama. Congresso da IFTA. Recuperado em 10 de junho de 2015, http://www.terapianarrativa.com.br/artigos/pos-moderno.pdf

Gregori, M. F. (1993). Cenas e queixas: um estudo sobre mulheres, relações violentas e práticas feministas. Rio de Janeiro: Editora Paz e Terra; São Paulo: ANPOCS.

Grossi, M. P., Minella, L. S., \& Losso, J. C. M. (2006). Gênero e violência: pesquisas acadêmicas brasileiras (1975-2005). Florianópolis: Mulheres.

Grossi, P. K. (1995). Violência contra a mulher: mitos e fatos. Educação, Porto Alegre, 18(29), 9399.

Grossi, P. K. (2013). Avanços e desafios da Lei Maria da Penha na garantia dos direitos das mulheres no RS. Seminário Internacional Fazendo Gênero 10: desafios atuais dos feminismos. Florianópolis. Recuperado em 16 de maio de 2015, de http://www.fazendogenero.ufsc.br/10/resources/anais/20/1386620845_ARQUIVO_Patricia KriegerGrossi.pdf

Guareschi, N. M. F., Weber, A., Comunello, L. N., Nardini, M. (2006). Discussões sobre violência: trabalhando a produção de sentidos. Psicologia: Reflexão e Crítica, 19(1), 122-130. Recuperado em 29 de maio de 2015, de http://www.scielo.br/readcube/epdf.php?doi=10.1590/S010279722006000100v19n1/31301. pdf

Guareschi, P. A. (2000). Ética, justiça e direitos humanos. In Conselho Federal de Psicologia - CFP (Org.), Psicologia, Ética e Direitos Humanos (pp. 11-21) ( $2^{\circ}$ ed.). São Paulo: Casa do Psicólogo.

Guimarães, F. (2009). “Mas ele diz que me ama...": impacto da história de uma vítima na vivência de violência conjugal de outras mulheres. Dissertação de mestrado. Instituto de Psicologia, Universidade de Brasília, Brasília. Recuperado em 1 de julho de 2011, de http://repositorio.bce.unb.br/bitstream/10482/5952/1/2009_FabricioGuimaraes.pdf

Guimarães, F., Silva, E. C., \& Maciel, S. A. B (2007). Resenha: "Mas ele diz que me ama...": Cegueira relacional e violência conjugal. Psicologia: Teoria e Pesquisa, 23(4), 481-482. Recuperado em 8 de junho de 2015, de http://www.scielo.br/pdf/ptp/v23n4/15.pdf

Guimarães, F., Diniz, G. R. S., \& Angelim, F. P. (no prelo). "Mas ele diz que me ama...": duplovínculo e nomeação da violência conjugal. Psicologia: Teoria e Pesquisa.

Guimarães, M. C. (2014). A formação pessoal de psicólogos/as e o trabalho com violência doméstica contra a mulher. Dissertação de Mestrado em Processos de Desenvolvimento Humano e Saúde, Instituto de Psicologia, Universidade de Brasília, Brasília. Recuperado em 4 de junho $\quad$ de $\quad 2015, \quad$ de http://repositorio.unb.br/bitstream/10482/16657/1/2014_MaisaCamposGuimaraes.pdf 
Hamilton, L., \& Armstrong, E. A. (2009). Gendered sexuality in young adulthood: double binds and flawed options. Gender \& Society, 23(5), 589-616.

Hamilton, L., Koehler, J. A., Lösel, F. A. (2013) Domestic Violence Perpetrator Programs in Europe, Part I: A survey of Current Practice. International Journal of Offender Therapy and Comparative Criminology, 57(10). Recuperado em 24 de maio de 2015, de http://ijo.sagepub.com/cgi/pmidlookup?view=long\&pmid=23267241

Hirigoyen, M. F. (2006). A violência no casal. Da coação psicológica à agressão física (M. H. Kuhner, Trad.). Rio de Janeiro: Bertrand Brasil (Trabalho original publicado em 2005).

Indicadores e Dados Básicos - Brasil. (2006). Saúde do homem. Brasília, DF: Rede Interagencial de Informações para a Saúde.

Instituto Brasileiro de Geografia e Estatística - IBGE (2009). Indicadores Sociodemográficos e de Saúde no Brasil. Rio de Janeiro: IBGE. Recuperado em 12 de maio de 2015, de http://www.ibge.gov.br/home/estatistica/populacao/indic_sociosaude/2009/indicsaude.pdf

Instituto Brasileiro de Geografia e Estatística - IBGE (2013). Pesquisa Nacional por Amostra de Domicílio. Rio de Janeiro: IBGE. Recuperado em 13 de junho de 2015, de http://www.ibge.gov.br/home/estatistica/populacao/trabalhoerendimento/pnad2013/

Instituto de Pesquisa Econômica Aplicada - IPEA (2014). Sistema de Indicadores de Percepção Social: tolerância social à violência contra as mulheres em nosso país. Brasília: IPEA.

Instituto Patrícia Galvão/Data Popular (2013). Percepção da sociedade sobre violência $e$ assassinatos de mulheres. São Paulo: Instituto Patrícia Galvão/Data Popular. Recuperado em 19 de maio de 2015, de http://agenciapatriciagalvao.org.br/wpcontent/uploads/2013/08/livro_pesquisa_violencia.pdf

Jablonski, B. (1991). Até que a vida nos separe: a crise do casamento contemporâneo. Rio de Janeiro: Agir.

Jablonski, B. (2003). Afinal, o que quer um casal? Algumas considerações sobre o casamento e a separação na classe média carioca. In T. Féres-Carneiro (Org.), Família e casal: arranjos e demandas contemporâneas (pp. 141-168). Rio de Janeiro: Ed. PUC-Rio; São Paulo: Loyola.

Juras, M. M. (2009). Papéis conjugais e parentais na situação de divórcio destrutivo com filhos pequenos. Dissertação de Mestrado, Instituto de Psicologia, Universidade de Brasília, Brasília. Recuperado em 5 de junho de 2015, de http://bdtd.bce.unb.br/tedesimplificado/tde_busca/arquivo.php?codArquivo=6321

Kimmel, M. S. (1997). Homofobia, temor, vergüenza y silencio en la identidad masculina. In T. Valdés \& J. Olavarría (Orgs.). Masculinidades: poder y crisis. Ediciones de las mujeres (pp. 49-62). Santiago: ISIS-FLACSO. (Original publicado em 1994). Recuperado em 11 de maio de 2015, de http://hombressinviolencia.org/docs/HOMOFOBIA.pdf

Knickmeyer, N., Levitt, H. M., Horne, S. G., \& Bayer, G. (2003). Responding to mixed messages and double binds: Religious oriented coping strategies of Christian battered women. Journal of Religion and Abuse, 5, 55-82.

Krug, E. G., Dahlberg, L. L., Mercy, J. A., Zwi, A. B. \& Lozano, R. (2002) Relatório mundial sobre violência e saúde. Geneva: Organização Mundial de Saúde. Recuperado em 5 de agosto de 2009, de http://www.opas.org.br/cedoc/hpp/ml03/0329.pdf

Levine, P. A., \& Frederick, A. (1999). O despertar do tigre: curando o trauma (4a ed.). São Paulo: Summus.

Lila, M., Gracia, E., \& Herrero, J. (2012). Asunción de responsabilidad en hombres maltratadores: influencia de la autoestima, la personalidad narcisista y la personalidad antisocial. Revista Latinoamericana de Psicología, 44(2), 99-108. Recuperado em 20 de maio de 2015, de http://www.scielo.org.co/pdf/rlps/v44n2/v44n2a09.pdf

Lima, D. C., \& Büchele, F. (2011). Revisão crítica sobre o atendimento a homens autores de violência doméstica e familiar contra as mulheres. Physis: Revista de Saúde Coletiva, 21(2), 721-743. Recuperado em 27 de abril de 2015, de http://www.scielo.br/pdf/physis/v21n2/a20v21n2.pdf 
Lima, D. C., Büchele, F., \& Clímaco, D. A. (2008). Homens, gênero e violência contra a mulher. Saúde e Sociedade, 17(2), 69-81. Recuperado em 27 de abril de 2015, de http://www.scielo.br/readcube/epdf.php?sausoc/v17n2/08.pdf.

Lobão, M., Resende, E., Roque, E. C. B., \& Brito, V. (2012). Conexões: Teoria e Prática do Trabalho em Redes na Secretaria Psicossocial Judiciária do TJDFT. Rio de Janeiro: Lumens Juris.

Lopes, P. V. L., \& Leite, F. (2013). Atendimento a homens autores de violência doméstica: desafios à política pública. Rio de Janeiro: ISER.

Lusa, M. G. (2008). Desconstruindo o heterocentrismo da violência nas relações conjugais. Reseña de "Casais e violência: um enfoque além do gênero" de Leonor M. Cantera. Revista Katálysis, 11(1), 149-151. Recuperado em 11 de maio de 2015, de http://www.redalyc.org/pdf/1796/179613968016.pdf

Macdonald, J., Monaem, A., Sliwka, G., Smith, A., Trezise, E. (2010). Pathways to Despair: the social determinants of male suicide (aged 25-44). Men's Health Information \& Resource Centre - MHIRC, Paper no. 2. Sidney: University of Western Sydney.

Macedo, D. S. (2013). Exercícios para Liberação da Tensão e do Trauma (TRE): aplicação a situações de violência conjugal. Dissertação de Mestrado, Instituto de Psicologia, Universidade de Brasília, Brasília.

Macedo, D., Guimarães, F., Tusi, M., Guimarães, R., Chaves, R. \& Ramos, T. (2012). Audiências interdisciplinares e violência contra a mulher: intervenções psicossociais no âmbito do TJDFT. In M. Lobão, E. Resende \& E. C. B. Roque, (Orgs.) \& V. Brito (Coord.), Conexões: Teoria e Prática do Trabalho em Redes na Secretaria Psicossocial Judiciária do TJDFT (pp. 13-32). Rio de Janeiro: Lumens Juris.

Machado, L. Z. (2014). Apresentação. In T. A. P. Ávila, B. A. Machado, A. H. G. Suxberger \& M. F. Távora, Modelos europeus de enfrentamento à violência de gênero: experiências e representações sociais. (pp. 11-18). Brasília: ESMPU.

Machado, M. H. (2000). Pratt, Mary Louise. Os Olhos do Império. Relatos de viagem e transculturação. Revista brasileira de História, 20(39), 281-289. Recuperado em 10 de junho

de 2015,

de http://www.scielo.br/readcube/epdf.php?doi=10.1590/S0102bh/v20n39/2990.pdf

Machin, R., Couto, M. T., Silva, G. S. N., Schraiber, L. B., Gomes, R., Figueiredo, W. S., Valença, O. A., \& Pinheiro, T. F. (2011). Concepções de gênero, masculinidade e cuidados em saúde: estudo com profissionais de saúde da atenção primária. Ciência \& Saúde Coletiva, 16(11), 4503-4512. Recuperado em 12 de maio de 2015, de http://www.scielo.br/pdf/csc/v16n11/a23v16n11.pdf

Maciel, S. A. B., \& Barbosa, A. C. G. (2010). Homens, masculinidades e Justiça. In I. GhestiGalvão \& E. C. B. Roque (Orgs.), Aplicação da lei em uma perspectiva interprofissional: Direito, psicologia, psiquiatria, serviço social e ciências sociais na prática jurisdicional (pp. 375 - 388). Brasília: Editora Lumen Juris.

Magalhães, N. T. (2011). Gênero e violência conjugal: olhares de um sistema de justiça especializado. Dissertação de Mestrado, Universidade de Brasília, Brasília.

Mahmoud, V. M. (2003). Os Duplos Vínculos do Racismo. In M. McGoldrick (Org.), Novas Abordagens da Terapia Familiar: Raça, Cultura e Gênero na prática clínica (pp. 293-307). São Paulo: Roca.

Manita, C. (2008). Programas de intervenção em agressores de violência conjugal: intervenção psicológica e prevenção da violência doméstica. Revista de Reinserção Social e Prova, 1, 21-32. Recuperado em 16 de abril de 2015, de http://repositorioaberto.up.pt/bitstream/10216/64477/2/91989.pdf

Manzanares, R. C., \& Salgado, C. A. (2013). Violencia de género y justicia. Santiago de Compostela: Servizo de Publicacións e Intercambio Científico, Universidade de Santiago de 
Compostela. Recuperado em 19 de maio de 2015, de http://www.psimae.es/imgx/articulos/capitulo_en_VdG_y_Justicia-Loinaz_2013.pdf

Martins, A. P. A., Cerqueira, D., \& Matos, M. V. M. (2015). Nota Técnica: A institucionalização das políticas públicas de enfrentamento à violência contra as mulheres no Brasil. Brasília: IPEA. Recuperado em 19 de maio de 2015, de http://www.ipea.gov.br/portal/images/stories/PDFs/nota_tecnica/150302_nt_diest_13.pdf

Matjasko, J. L., Vivolo-Kantor, A. M., Massetti, G. M., Holland, K. M., Holt, M. K., Cruz, J. D. (2012). A systematic meta-review of evaluations of youth violence prevention programs: Common and divergent findings from 25 years of meta-analyses and systematic reviews. Aggression and Violent Behavior, 17, 540-552. Recuperado em 24 de maio de 2015, de http://www.sciencedirect.com/science/article/pii/S1359178912000857

McGoldrick, M. (1994). As mulheres e o ciclo de vida familiar. Em B. Carter \& M. McGoldrick. $O$ ciclo de vida familiar: uma abordagem para a terapia familiar. Porto Alegre: Artes Médicas.

McGoldrick, M. (2003). Novas abordagens da terapia familiar: raça, cultura e gênero na prática clínica. São Paulo: Roca.

Medeiros, G. A. (2002). Por uma Ética na Saúde: algumas reflexões sobre a Ética e o Ser Ético na atuação do psicólogo. Psicologia: Ciência e Profissão, 22 (1); 30-37.

Medeiros, M. N. (2010). Violência conjugal: repercussões na saúde mental de mulheres e de suas filhas e seus filhos adultas/os jovens. Dissertação de Mestrado, Instituto de Psicologia, Universidade de Brasília, Brasília.

Medeiros, M. N. (2015). Avaliação de risco em casos de violência perpetrada por parceiro íntimo: a identificação da reincidência e da letalidade. Tese de Doutorado, Instituto de Psicologia, Universidade de Brasília, Brasília.

Medrado, B. (2009). A Lei Maria da Penha não é contra os homens, é a favor de uma sociedade sem violência: conquistas, lacunas e desafios em políticas públicas. In C. S. Tornquist, C. C. Coelho, M. C. S. Lago \& T. K. Lisboa (Orgs.). Leituras de resistência: corpo, violência e poder (pp. 20-35). Florianópolis: Editora Mulheres, v. 2.

Medrado, B. (2010). Prefácio. In M. J. F. Toneli, A. Beiras, A. D. A. Clímaco, \& M. C. S. Lago, Atendimento a homens autores de violência contra mulheres: Experiências latinoamericanas. (pp. 7-9). Florianópolis: UFSC/CFH/NUPPE.

Medrado, B., \& Lyra, J. (2008). Por uma matriz feminista de gênero para os estudos sobre homens e masculinidades. Rev. Estud. Fem., Florianópolis, 16(3). Recuperado em 19 de maio de 2015, de http://www.scielo.br/pdf/ref/v16n3/05.pdf

Medrado, B., \& Méllo, R. P. (2008). Posicionamentos críticos e éticos sobre a violência contra as mulheres. Psicol. Soc. vol.20, no.spe, p.78-86. ISSN 0102-7182. Recuperado em 16 de abril de 2015, de http://www.scielo.br/pdf/psoc/v20nspe/v20nspea11.pdf

Medrado, B., Lemos, A. R., \& Brasilino, J. (2011). Violência de gênero: paradoxos na atenção a homens. Psicologia em Estudo, 16(3), 471-478. Recuperado em 11 de março de 2015, de http://www.scielo.br/pdf/pe/v16n3/v16n3a14.pdf

Meneghel, S. N., \& Hirakata, V. N. (2011). Femicídios: homicídios femininos no Brasil. Rev Saúde Pública. 45(3), 564-74.

Minayo, M. C. S. (1998). O desafio do conhecimento: pesquisa qualitativa em saúde. (5ª ed.). São Paulo: Hucitec.

Minayo, M. C. S. (2001). Pesquisa social: teoria método e criatividade (18 a ed.). Petrópolis: Vozes.

Minayo, M. C. S. (2013). Conceitos, teorias e tipologias de violência: a violência faz mal à saúde individual e coletiva. In K. Njaine, S. G. de Assis \& P. Constantino (Orgs.), Impactos da Violência na Saúde (pp. 21-42) (3ª ed.). Rio de Janeiro: Fundação Oswaldo Cruz.

Moore, R. A. (2015). Violência e gênero: vulnerabilidade masculina. Dissertação de Mestrado, Instituto de Psicologia, Universidade de Brasília. Recuperado em 3 de junho de 2015, de http://repositorio.unb.br/bitstream/10482/18126/1/2015_RafaelAlbertoMoore.pdf 
Moreira, A. D., \& Matta, K. W. (2006). Grupo de Conversação sobre as Relações: Espaço de Reflexão na Justiça para Pessoas em Situação de Violência Intrafamiliar. In E. C. B. Roque, M. L. R. Moura \& I. Ghesti (Orgs.), Novos paradigmas na Justiça Criminal: Relatos de experiências do Núcleo Psicossocial Forense do TJDFT (pp. 223-234). Brasília: TJDFT. Recuperado em 1 de maio de 2015, de http://www.tjdft.jus.br/publicacoes/edicoesespeciais/livros/novosp.pdf

Narvaz, M. G., \& Koller, S. H. (2006). Mulheres vítimas de violência doméstica: compreendendo subjetividade assujeitadas. Psico, Porto Alegre, 37(1), 7-13. Recuperado em 9 de agosto de 2008 ,

http://revistaseletronicas.pucrs.br/ojs/index.php/revistapsico/article/viewFile/1405/1105

Nascimento, E. F., Gomes, R., \& Rebello, L. E. F. S. (2009). Violência é coisa de homem? A naturalização da violência nas falas de homens jovens. Ciência \& Saúde Coletiva, 14(4), 1151-1157. Recuperado em 11 de maio de 2015, de http://www.scielo.br/pdf/csc/v14n4/a16v14n4.pdf

Nichols, M. P., \& Schwartz, R. C. (2007). Terapia familiar: conceitos e métodos. (7 ${ }^{\mathrm{a}}$ ed.). Porto Alegre: Artmed.

Nolasco, S. (1993). O mito da masculinidade. Rio de Janeiro: Rocco.

Nolasco, S. (2001). De Tarzan a Simpson, banalização e violência masculina. Rio de Janeiro: Rocco.

Norman, M. E. (2011). Embodying the double-bind of masculinity: young men and discourses of normalcy, health, heterosexuality, and individualism. Men and Masculinities, 0(0), 1-20. $\begin{array}{llllll}\text { Recuperado em } 30 \text { de } & \text { maio }\end{array}$ http://jmm.sagepub.com/content/early/2011/05/20/1097184X11409360.full.pdf

Ogando, A. C. F. L. (2010). Entre o público e privado: as relações de gênero no pensamento positivista e católico (1870-1889). Seminário Internacional Fazendo Gênero 9: diásporas, diversidades, deslocamentos. Florianópolis. Recuperado em 10 de junho de 2015, de http://www.fazendogenero.ufsc.br/9/resources/anais/1278290628_ARQUIVO_fazendogener o_vf.pdf

Oliveira, A. L. P. (2015). "Se você ficar com nossos filhos, eu te mato!" Violência doméstica e familiar contra a mulher e as disputas de guarda de filhos/as em trâmite nas Varas de Família de Ceilândia/DF. Dissertação de Mestrado, Faculdade de Direito, Universidade de Brasília, Brasília. Recuperado em 22 de julho de 2015, de http://repositorio.unb.br/handle/10482/18401

Oliveira, K. L. C., \& Gomes, R. (2011). Homens e violência conjugal: uma análise de estudos brasileiros. Ciênc. saúde coletiva, 16(5), 2401-2413. Recuperado em 15 de abril de 2015, de http://www.scielosp.org/pdf/csc/v16n5/a09v16n5

Organização das Nações Unidas - ONU (2000). Declaração do Milênio. Nova Iorque: ONU. $\begin{array}{llllll}\text { Recuperado em } 20 \text { de maio de } & \end{array}$ http://www.pnud.org.br/Docs/declaracao_do_milenio.pdf

Organização das Nações Unidas - ONU (2006). In-depth study on all forms of violence against women: report of the secretary-general. Nova Iorque: ONU. Recuperado em 27 de abril de 2015, de http://daccess-ods.un.org/TMP/1312907.63616562.html

Organização das Nações Unidas - ONU (2010). The World's Women 2010: Trends and Statistics. Nova Iorque: ONU. Recuperado em 13 de junho de 2015, de http://unstats.un.org/unsd/publication/SeriesK/SeriesK_19s.pdf

Organização das Nações Unidas - ONU Mulher (2015). Progress of the World's Women 20152016: Transforming economies, realizing rights. Nova Iorque: ONU. Recuperado em 13 de junho de 2015, de http://progress.unwomen.org/en/2015/pdf/UNW_progressreport.pdf

Organização das Nações Unidas para a Educação, a Ciência e a Cultura - UNESCO \& Brasil. Presidência da República (2015). Índice de vulnerabilidade juvenil à violência $e$ desigualdade racial 2014. Secretaria-Geral da Presidência da República, Secretaria Nacional 
de Juventude, Ministério da Justiça e Fórum Brasileiro de Segurança Pública. Brasília: Presidência da República.

Organização dos Estados Americanos - OEA (1994). Convenção Interamericana para Prevenir, Punir e Erradicar a Violência contra a Mulher. Brasil: Comissão Interamericana de Direitos Humanos - OEA. Recuperado em 4 de agosto de 2009, de http://cidh.oas.org/Basicos/Portugues/m.Belem.do.Para.htm

Organização Mundial de Saúde - OMS (2001). Dando prioridade a las mujeres: Recomendaciones éticas y de seguridad para la investigación sobre la violência domestica contra lãs mujeres. Genebra: Organização Mundial de Saúde. Recuperado em 8 de agosto de 2008, de http://whqlibdoc.who.int/hq2001/WHO_FCH_GWH_01.1.pdf

Organização Mundial de Saúde - OMS (2005). Estudio multipaís de la OMS sobre salud de la mujer y violencia doméstica contra la mujer: primeros resultados sobre prevalencia, eventos relativos a la salud y respuestas de las mujeres a dicha violencia. Genebra: Organização Mundial de Saúde. Recuperado em 5 de agosto de 2008, de http://www.who.int/gender/violence/who_multicountry_study/summary_report/summaryrep ortSpanishlow.pdf

Pandjiarjian, V. (2002). Os estereótipos de gênero nos processos judiciais e a violência contra a mulher na legislação. Rio de Janeiro: IPAS-Brasil. Recuperado em 2 de agosto de 2008, de http://www.ipas.org.br/arquivos/valeria/painel.doc

Papp, P. (2002). Casais em perigo: novas diretrizes para terapeutas. Porto Alegre: Artes Médicas.

Penfold, R. B. (2006). Mas ele diz que me ama: graphic novel de uma relação violenta. (D. Pelizzari, trad.) . Rio de Janeiro: Ediouro. (Original publicado em 2005).

Ponce-Antezana, A. (2012). Intervenção com homens que praticam violência contra seus cônjuges: reformulações teórico-conceituais para uma proposta de intervenção construtivistanarrativista com perspectiva de gênero. Revista Nova Perspectiva Sistêmica, 42, 9-25.

Pondaag, M. C. M. (2003). O dito pelo não dito: desafios no trabalho com mulheres vítimas de violência. Dissertação de Mestrado, Instituto de Psicologia, Universidade de Brasília, Brasília.

Pondaag, M. C. M. (2009). Sentidos da Violência Conjugal: a perspectiva de casais. Tese de Doutorado, Instituto de Psicologia, Universidade de Brasília, Brasília.

Pontes, H (2004). Modas e Modos: uma leitura enviesada de O espírito das roupas. Cadernos Pagú, 24, 13-46. Recuperado em 10 de junho de 2015, de http://www.scielo.br/readcube/epdf.php?doi=10.1590/S0104/n22/n22a03.pdf

Porto, M. \& Costa, F. P. (2010). Lei Maria da Penha: as representações do judiciário sobre violência contra mulher. Estudos de Psicologia. 27(4), 479-489.

Pratt, M. L. (1993). Mulher, literatura e irmandade nacional. In H. B. Holanda (Org.), Tendências $e$ Impasses: o feminismo como crítica da cultura. Rio de Janeiro: Rocco.

Programa das Nações Unidas para o Desenvolvimento - PNUD Brasil/IPEA (2014). Objetivos de Desenvolvimento do Milênio: relatório nacional de acompanhamento. Brasília: IPEA. Recuperado em 20 de maio de 2015, de http://www.pnud.org.br/Docs/5_RelatorioNacionalAcompanhamentoODM.pdf

Ramos, M. E. V. (2013). Homens e mulheres envolvidos em violência e atendidos em grupos socioterapêuticos: união, comunicação e relação. Revista Brasileira de Psicodrama, 21(1), 39-53. Recuperado em 19 de maio de 2015, de http://pepsic.bvsalud.org/pdf/psicodrama/v21n1/a04.pdf

Randle, A. A., \& Graham, C. A. (2011). A review of the evidence on the effects of intimate partner violence on men. Psychology of Men \& Masculinity, 12(2), 97-111. Recuperado em 18 de maio de 2015, de http://dx.doi.org/10.1037/a0021944

Rangel, R.B. \& Tusi, M.M.A. (2010). Além das fronteiras: Atuação interdisciplinar no Fórum da Ceilândia. In I. Ghesti-Galvão \& E. C. B. Roque (Orgs.), Aplicação da lei em uma 
perspectiva interprofissional: Direito, psicologia, psiquiatria, serviço social e ciências sociais na prática jurisdicional (pp. 457-466). Brasília: Editora Lumen Juris.

Ravazzola, M. C. (1997). Historias infames: los maltratos em las relaciones. Buenos Aires: Paidós.

Ravazzola, M. C. (1998). Violencia familiar: el abuso relacional como un ataque a los derechos humanos. Sistemas Familiares, 4(3), 29-41.

Ravazzola, M. C. (2007). Violência nas Relações Familiares: Por que uma visão sistêmica e de gênero? Pensando Famílias, 11 (1), 11-28.

Ravazzola, M. C. (2015) Algunas propuestas en el tema de la violencia doméstica. Página 12, Recuperado em 27 de junho de 2015, de http://www.pagina12.com.ar/diario/sociedad/3275503-2015-06-23.html

Ribeiro, R. \& Costa, L. F. (2007). As emoções do profissional psicossocial frente à situação de abuso sexual infantil. Estilos da Clinica, 12(23), 108-129.

Rodrigues, C. (2005). Butler e a desconstrução de gênero. Revista Estudos Feministas, 13(1), 179183. Recuperado em 10 de junho de 2015, de http://www.scielo.br/readcube/epdf.php?doi=10.1590/ref/v13n1/a12v13n1.pdf

Roque, E. C. B., Moura, M. L. R., \& Ghesti, I. (2006). Novos paradigmas na Justiça Criminal: Relatos de experiências do Núcleo Psicossocial Forense do TJDFT. Brasília: TJDFT. Recuperado em 1 de maio de 2015, de http://www.tjdft.jus.br/publicacoes/edicoesespeciais/livros/novosp.pdf

Rothman, E. F., Butchart, A., \& Cerda, M. (2003). Intervening with perpetrators of intimate partner violence: a global perspective. Geneva: World Health Organization. Recuperado em 27 de abril de 2015, de http://whqlibdoc.who.int/publications/2003/9241590491.pdf?ua=1

Saffioti, H. I. B. (1999). Já se mete a colher em briga de marido e mulher. Perspectiva, São Paulo, 13(4), 82-91. Recuperado em 1 de agosto de 2008, de http://www.scielo.br/pdf/spp/v13n4/v13n4a08.pdf

Santos, A. C. W. \& Moré, C. L. O. O. (2011). Repercussão da violência na mulher e suas formas de enfrentamento. Paidéia (Ribeirão Preto), 21(49), 227-235.

Santos, G. K. F. (2015). Impactos da metodologia de Grupos Mistos em situações de violência doméstica na Justiça. Trabalho de Conclusão de Curso, Departamento de Psicologia, Universidade Católica de Brasília, Brasília.

Schimidt, R. T. (2009). Mulheres reescrevendo a nação. In A. Piscitelli (Org.), Olhares Femininos. Brasília: Ministério da Educação.

Schmidt, B. B. L. B. (2010). Ciclos de violência e alcoolismo na conjugalidade: construções subjetivas dos homens agressores e alcoolistas. Dissertação de mestrado. Instituto de Psicologia, Universidade de Brasília, Brasília.

Scott, J. (2005). O enigma da igualdade. Revista Estudos Feministas, 13(1), 11-30. Recuperado em 10 de junho de 2015, de http://www.scielo.br/pdf/ref/v13n1/a02v13n1.pdf

Scott, J. W. (1995). Gênero: uma categoria útil de análise histórica. Educação e Realidade, 20(2), 71-99.

Scott, K., King, C., McGinn, H., \& Hosseini, N. (2011). Effects of Motivational Enhancement on Immediate Outcomes of Batterer Intervention. J Fam Viol, 26, 139-149. Recuperado em 24 de maio de 2015, de http://link.springer.com/article/10.1007/s10896-010-93531/fulltext.html

Seidl de Moura, M. L. \& Ferreira, M. C. (2005). Projetos de Pesquisa: Elaboração, redação e apresentação. Rio de Janeiro, RJ: EDUERJ.

Separavich, M. A., \& Canesqui, A. M. (2013). Saúde do homem e masculinidades na Política Nacional de Atenção Integral à Saúde do Homem: uma revisão bibliográfica. Saúde $e$ Sociedade, 22(2), 415-428. Recuperado em 15 de abril de 2015, de http://www.scielo.br/pdf/sausoc/v22n2/v22n2a13.pdf

SEPSI/TJDFT (2009). Práticas psicossociais no Tribunal de Justiça do Distrito Federal e dos Territórios. Brasília: SUGRA/TJDFT. 
Serviço de Assessoramento aos Juízos Criminais - SERAV (2012). Conheça o SERAV. Brasília: SUGRA/TJDFT.

Silva, I. B. S. (2012). Violência conjugal e autoimagem de mulheres. Trabalho de Conclusão de Curso, Pós-Graduação em Psicologia Jurídica, Instituto de Educação Superior de Brasília IESB, Brasília.

Silva, I. M., \& Sattler, M. K. (2015). As raízes do ciúme: uma compreensão a partir das experiências vivenciadas na família de origem. In T. Almeida (Org.), Relacionamentos Amorosos: O Antes, o durante e o depois - V. 03 (pp. 251-281). São Paulo: Polo Books. $\begin{array}{llllll}\text { Recuperado em } 29 \text { de junho de } & \end{array}$ http://www.thiagodealmeida.com.br/site/files/livros/Relacionamentos_amorosos_o_antes_o _durante_e_o_depois_Voume_3.pdf

Silva, L. L., Coelho, E. B. S., \& Caponi, S. N. C. (2007). Violência silenciosa: violência psicológica como condição da violência física doméstica. Interface - Comunicação, Saúde, Educação, 11(21), 93-103. Recuperado em 08 de junho de 2015, de http://www.scielo.br/scieloOrg/php/articleXML.php?pid=S141432832007000100009\&lang=en

Silveira, P., Medrado, B., \& Rodrigues, L. O. (2009). Sentidos de violência contra as mulheres nas narrativas de homens denunciados por violência conjugal. Cadernos Saúde Coletiva (UFRJ), v. XVII, 951-970. Recuperado em 17 de maio de 2015, de http://gemaufpe.blogspot.com.br/p/textos.html

Siqueira, M. B. (2012). Violência conjugal e paternidade: o significado de ser pai para homens agressores. Trabalho de Conclusão de Curso, Pós-Graduação em Psicologia Jurídica, Instituto de Educação Superior de Brasília - IESB, Brasília.

Soares, B. M. (2005). Enfrentando a violência contra a mulher: orientações práticas para profissionais e voluntários(as). Brasília: Secretaria Especial de Políticas para as Mulheres SPM.

Soares, B. M. (2006). A violência doméstica e as pesquisas de vitimização. Em II Encontro Nacional de Produtores e Usuários de Informações Sociais, Econômicas e Territoriais. Rio de Janeiro: IBGE. Recuperado em 1 de agosto de 2009, de www.ibge.gov.br/confest_e_confege/pesquisa_trabalhos/arquivosPDF/M705_01.pdf

Soares, B. M. (2012). A 'conflitualidade' conjugal e o paradigma da violência contra a mulher. DILEMAS: Revista de Estudos de Conflito e Controle Social, 5(2), 191-210. Recuperado em 19 de maio de 2015, de http://revistadil.dominiotemporario.com/doc/dilemas-5-2-art1.pdf

Soares, G. A. D. (2002). Matar e, depois morrer. Opinião Pública, 8(2), 275-303. Recuperado em 8 de junho de 2015, de http://www.scielo.br/pdf/op/v8n2/14881.pdf

Souzas, R. \& Alvarenga, A. T. (2001). Da negociação às estratégias: relações conjugais e de gênero no discurso de mulheres de baixa renda em São Paulo. Saúde e Sociedade, São Paulo, 10(2), 15-31.

Teixeira, A. B. (2009). Nunca você sem mim: homicidas-suicidas nas relações afetivo-conjugais. São Paulo: Annablume.

Toneli, M. J. F., Beiras, A., Climaco, A. D. A., \& Lago, M. C. S. (2010). Atendimento a homens autores de violência contra mulheres: Experiências latino-americanas. Florianópolis: $\mathrm{UFSC/CFH/NUPPE.}$

Toneli, M. J. F., Lago, M. C. S., Beiras A. L., \& Clímaco, A. D. A. (2008). Programas de atenção a homens que cometem agressão contra mulheres: propostas latino-americanas e estadunidenses: debates em torno a propostas feministas e judiciais. In: Anais do Seminário Internacional Fazendo Gênero 8 - Corpo Violência e Poder; Florianópolis. Recuperado em 15 de abril de 2015, de http://www.fazendogenero.ufsc.br/8/sts/ST21/Toneli-Lago-BeirasLodetti-Climaco_21.pdf 
Tribunal de Contas da União - TCU (2013). Acórdão 403/2013 - Auditoria sobre a Lei Maria da Penha. Brasilia: TCU. Recuperado em 29 de maio de 2015, de www.tcu.gov.br/Consultas/Juris/.../20130219/AC_0403_02_13_1.doc

Vazquez, G. G. (2014). Estratégias de resolução de conflito conjugal entre casais: semelhanças e diferenças. Dissertação de Mestrado, Instituto de Psicologia, Universidade de Brasília, Brasília. Recuperado em 10 de junho de 2015, http://repositorio.unb.br/bitstream/10482/18343/1/2014_GreisyGonzalezVazquez.pdf

Veloso, F. G. C., \& Natividade, C. (2013). Metodologias de abordagem dos homens autores de violência contra as mulheres. In P. V. L. Lopes \& F. Leite (Orgs.). Atendimento a homens autores de violência doméstica: desafios à política pública (pp. 44-64). Rio de Janeiro: ISER.

Waiselfisz, J. J. (2012). Mapa da Violência 2012. Os novos padrões da violência homicida no Brasil-Caderno Complementar 1: Homicídios de Mulheres no Brasil. São Paulo: Instituto Sangari.

Waiselfisz, J. J. (2014). Mapa da Violência 2014: os jovens do Brasil. Brasília: Secretaria-Geral da Presidência da República, Secretaria Nacional de Juventude, Secretaria de Políticas de Promoção da Igualdade Racial.

Waiselfisz, J. J. (2015). Mapa da Violência 2015: mortes matadas por armas de fogo. Brasília: Secretaria-Geral da Presidência da República, Secretaria Nacional de Juventude, Secretaria de Políticas de Promoção da Igualdade Racial. Recuperado em 15 de maio de 2015, de http://www.mapadaviolencia.org.br/pdf2015/mapaViolencia2015.pdf

Waiselfisz, J. J. (2015a). Mapa da Violência 2015: Homicídios de Mulheres no Brasil. Brasília: Secretaria-Geral da Presidência da República, Secretaria Nacional de Juventude, Secretaria de Políticas de Promoção da Igualdade Racial.

Walker, L. E. (1979). The battered woman. Nova York: HarperPerennial.

Walker, L. E. A. (1999). The battered woman syndrome. (2ºd.). Nova York: Springer Publishing Company.

Walker, L. E., Duros, R. I., \& Tome, A. (2007). The battered woman syndrome. Recuperado em 8 de junho de 2015, de http://www.cavis.es/sitio/index2.php?option=com_docman\&task=doc_view\&gid=147\&Ite $\underline{\operatorname{mid}=46}$

Watzlawick, P., Beavin, J. H., \& Jackson, D. D. (2007). Pragmática da comunicação humana: um estudo dos padrões, patologias e paradoxos da interação. São Paulo: Cultrix. (Original publicado em 1967).

Welzer-Lang, D. (2001). A construção do masculino: dominação das mulheres e homofobia. Revista Estudos Feministas, 9(2), 460-482. Recuperado em 11 de maio de 2015, de http://www.scielo.br/pdf/ref/v9n2/8635.pdf

Williams, L. C. A. (2001). Lições de Gravelina: violência fatal contra a mulher. Revista Olhar, São Carlos, 3(5-6), 1-10. Recuperado em 1 de agosto de 2008, de http://www.ufscar.br/laprev/arquivos/publicacoes/Licoes_de_Gravelinaviolencia_fatal contra.pdf

Yamamoto, A., \& Colares, E. S. (2015). Por que falar em feminicídio? Observa Gênero, 47(7), 5-7. Recuperado em 30 de maio de 2015, de http://agenciapatriciagalvao.org.br/wpcontent/uploads/2015/05/BOLETIM-OBSERVA-GeNERO_N47_maio.pdf

Zampieri, A. M. F. (1996). Sociodrama Construtivista da AIDS. Campinas: PSY.

Zampieri, A. M. F. (2009). Sociodrama Construtivista como estratégia de prevenção para o "empoderamento" de profissionais de Saúde e Educação. Tese de pós-doutorado, Psicologia Clínica, Pontifícia Universidade Católica de São Paulo - PUC/SP, São Paulo.

Zampieri, A. M. F. (2011). Programa de ajuda humanitária psicológica: manual de capacitação. São Paulo: ABRAPAHP. 
Zordan, E. P., Dellatorre, R., \& Wieczorek, L. (2012). A entrevista na terapia familiar sistêmica: pressupostos teóricos, modelos e técnicas de intervenção. Perspectiva, 36(136), 133-142. Recuperado em 10 de junho de 2015, de http://www.uricer.edu.br/site/pdfs/perspectiva/136_314.pdf

Zuma, C. E, Mendes, C. H. F., Cavalcanti, L. F., \& Gomes, R. (2013). Violência de gênero na vida adulta. In K. Njaine, S. G. de Assis \& P. Constantino (Orgs.), Impactos da Violência na Saúde (pp. 149-186) ( $3^{\text {a }}$ ed.). Rio de Janeiro: Fundação Oswaldo Cruz. 
Anexos

Anexo I

Questionário sobre o Livro: "Mas ele diz que me ama...”" ( $1^{\text {a }}$ Etapa)

1. Qual foi o sentimento (ou sentimentos) que você teve ao ler este livro?

2. O que tem de comum/parecido na história do seu relacionamento e na história dos personagens do livro - Roz e Brian?

3. O que tem de diferente em sua história?

4. Na folha em anexo, marque com um " $X$ " quais pensamentos/sentimentos da Roz são parecidos com os pensamentos que você tem ou teve.

5. Escolha 3 desses pensamentos/sentimentos que mais influenciaram em sua história:

a)

b)

c)

6. Além dos pensamentos apresentados pela Roz, você teve outros que te impediram de pedir ajuda, quebrar o ciclo de violência ou de sair do relacionamento?

( ) Não ( ) Sim. Quais?

a)

b)

c)

7. A Roz resumiu a história dela com o título: "Mas ele diz que me ama...". Qual seria o título da sua história?

8. Inspirado em sua história, complete a frase/título do livro:

"Mas ele diz que me ama, 


\section{Anexo II}

Contracapas do livro "Mas ele diz que me ama" (Penfold, 2005/2006)

Marque com um " $\mathrm{X}$ " quais pensamentos/sentimentos são parecidos com os pensamentos que você tem ou teve.

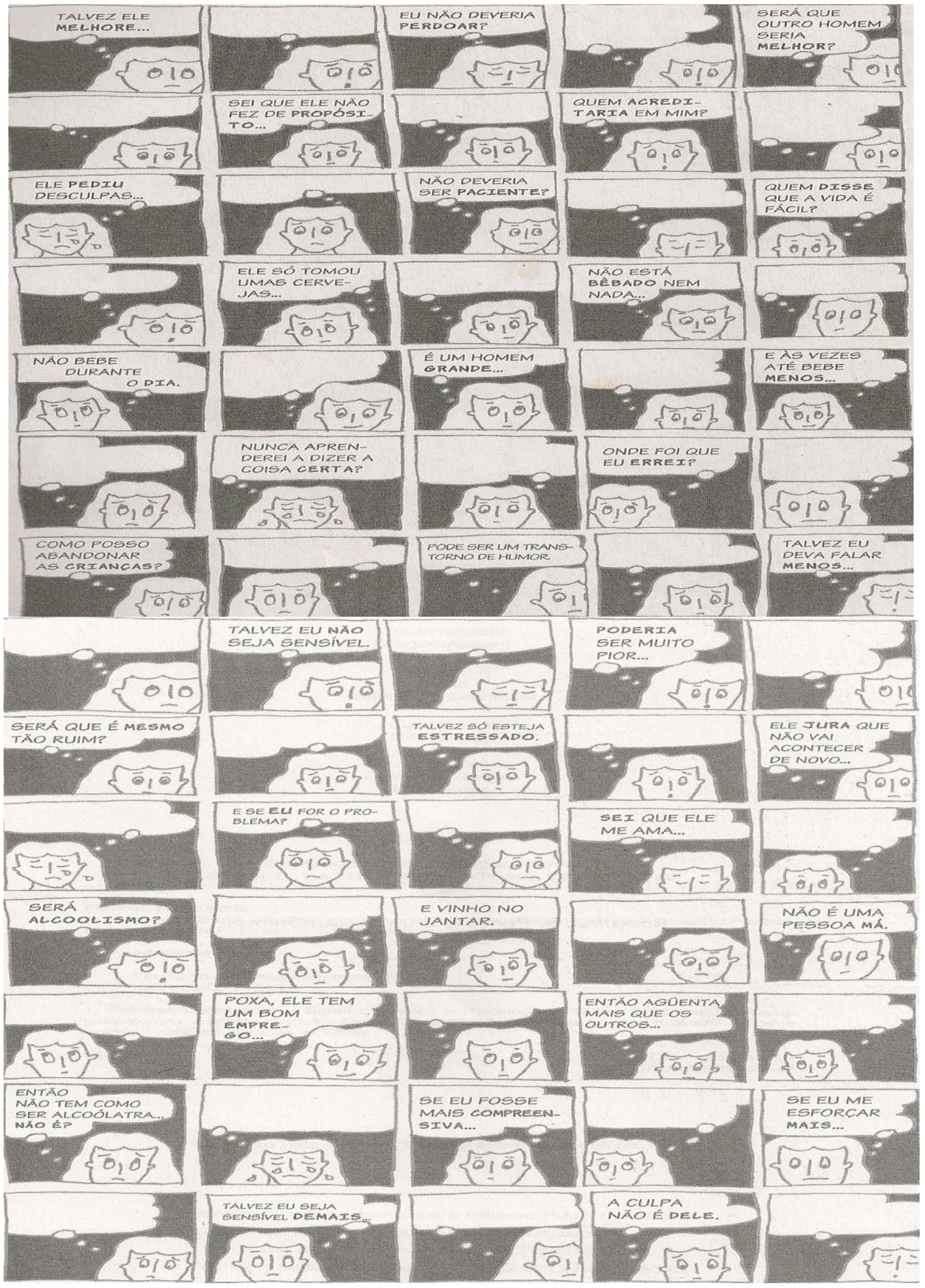




\section{Anexo III \\ Questionário sobre o Livro: "Mas ele diz que me ama...” (2 $2^{\mathrm{a}}$ Etapa)}

1. Qual foi o sentimento (ou sentimentos) que você teve ao ler essa história?

2. O que tem de parecido na história de seu relacionamento e na história de Brian e Roz?

3. O que tem de diferente em sua história?

4. No anexo, marque com um " $X$ " quais pensamentos/sentimentos são parecidos com os pensamentos que você tem ou teve.

5. Escolha 3 desses pensamentos/sentimentos que mais influenciaram a sua história:

a)

b)

c)

6. Você teve outros pensamentos/sentimentos que te impediram de perceber as consequências da violência e/ou pedir ajuda?

( ) Não

( ) Sim. Quais?

a)

b)

c)

7. Um homem resumiu a história dele com a frase: "Será que o erro está em mim?" Qual é o título da sua história?

8. Inspirado em sua história, complete as frases abaixo:

"Quem ama não bate, mas

"Fui amado, mas 


\section{Anexo IV}

Marque com um "X" quais pensamentos/sentimentos são parecidos com os pensamentos que você tem ou teve
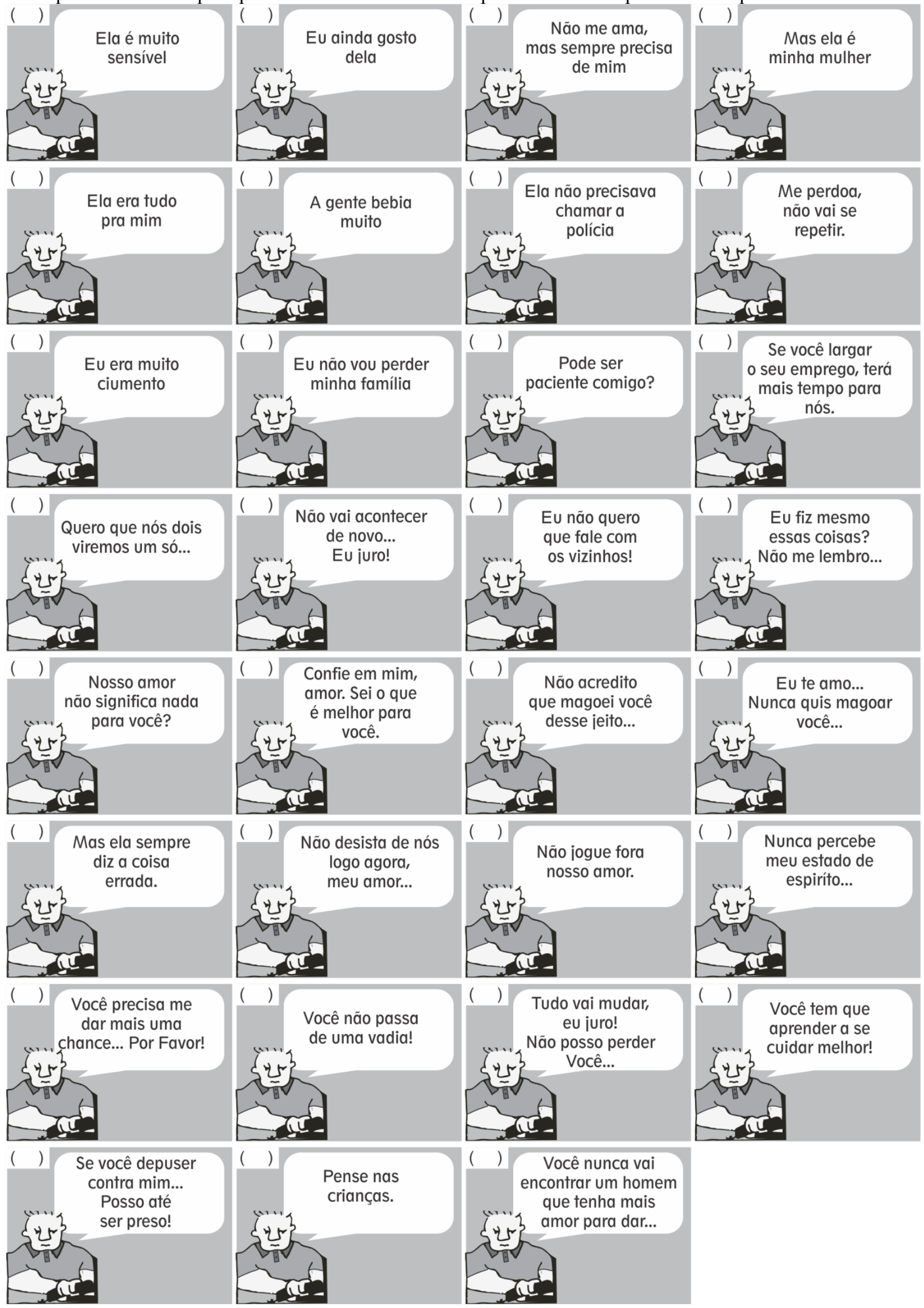


\section{Anexo V}

\section{Ficha de Evolução - GRUPO MISTO}

Nome: Caso:

Nome da outra parte:

JUFAM: $\square 1^{\circ} \square 2^{\circ}$ Grupo: $\square$ G1 $\square$ G2 $\square$ G3

Dia da semana: $\square$ segunda-feira $\square$ terça-feira $\square$ quarta-feira $\square$ quinta-feira

- Separados ( ) Sim ( ) Não

- A parte aceita essa decisão? ( ) Sim ( ) Não

- Há Medida Protetiva? ( ) Sim ( ) Não - Está sendo cumprida? ( ) Sim ( ) Não

Observações:

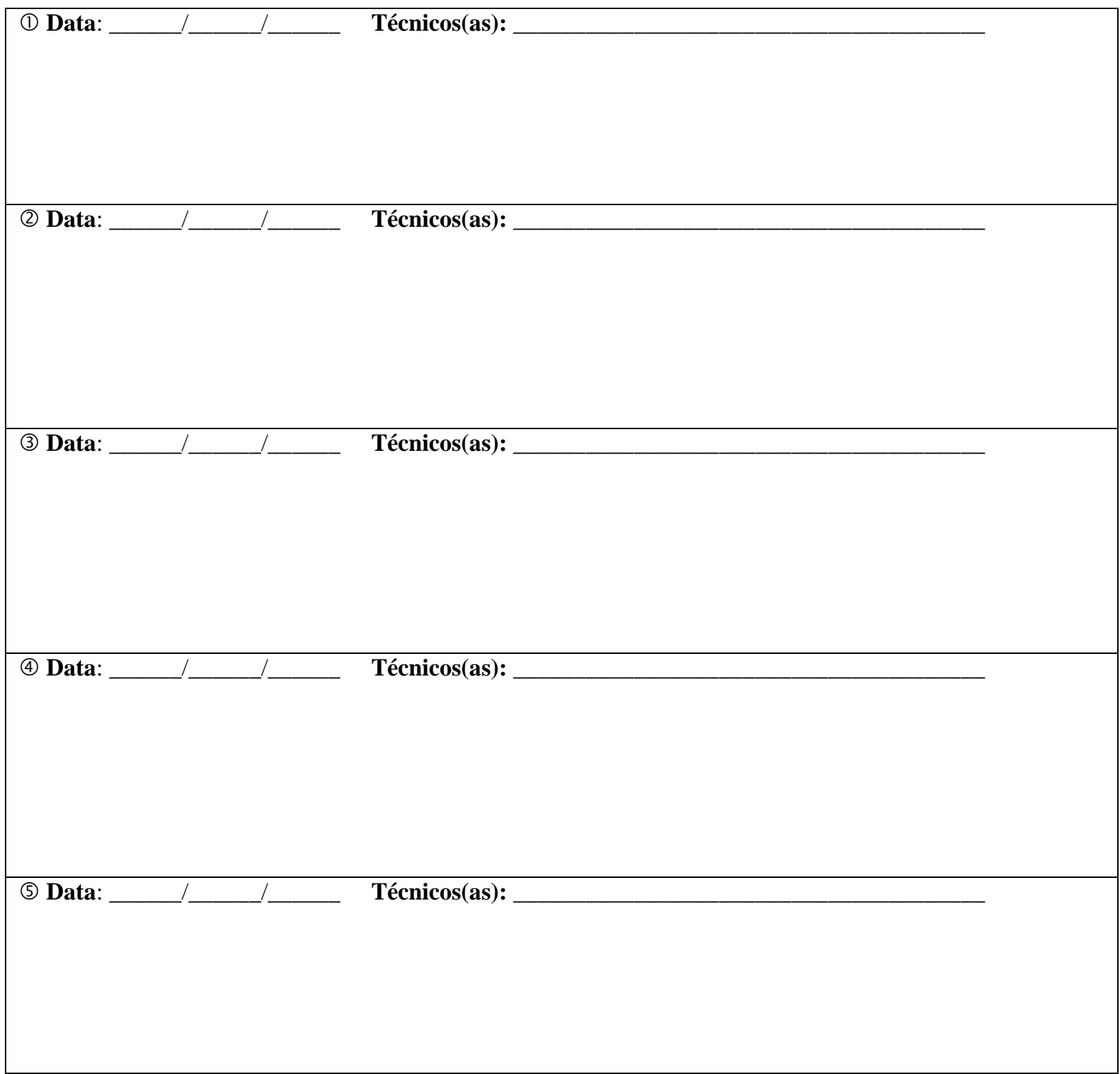

- Refletiu sobre seu papel na construção da relação violenta/corresponsabilidade? ( )Sim ( )Não

- Encaminhamento: ( ) pediu ( ) aceitou ( ) negou

- Encaminhamento: ( )NPJ/UnB ( )Caps-AD ( )Nafavd ( )Outros: 
Anexo VI

\section{Controle de Empréstimo do Livro}

CONTROLE DE EMPRÉSTIMO

Eu me comprometo a devolver o livro "MAS ELE DIZ QUE ME AMA", no prazo máximo de uma semana ou até o próximo atendimento agendado, mesmo que não possa participar dos encontros subseqüentes ou tenha concluído o acompanhamento psicossocial.

\begin{tabular}{|c|c|c|c|c|c|c|}
\hline $\begin{array}{l}\text { Número } \\
\text { do Caso }\end{array}$ & Nome Completo & Telefone & $\begin{array}{c}\text { Data } \\
\text { Empréstimo }\end{array}$ & Data Devolução & Técnico(a) & Assinatura \\
\hline & & & & & & \\
\hline & & & & & & \\
\hline & & & & & & \\
\hline & & & & & & \\
\hline & & & & & & \\
\hline & & & & & & \\
\hline & & & & & & \\
\hline & & & & & & \\
\hline & & & & & & \\
\hline & & & & & & \\
\hline & & & & & & \\
\hline
\end{tabular}




\section{Anexo VII \\ TERMO DE CONSENTIMENTO LIVRE E ESCLARECIDO}

Você está sendo convidado/a a participar da pesquisa de doutorado intitulada: “'Mas ela é minha mulher...': Impactos da história de uma mulher vítima na vivência de violência conjugal de homens". O estudo será realizado pelo pesquisador Fabrício Lemos Guimarães, aluno de doutorado do Programa de Pós-Graduação em Psicologia Clínica e Cultura - PsiCC, do Departamento de Psicologia Clínica - PCL, vinculado ao Instituto de Psicologia da Universidade de Brasília, sob a orientação da Prof ${ }^{a}$. Gláucia Ribeiro Starling Diniz, PhD. O pesquisador é psicólogo do Serviço de Assessoramento aos Juízos Criminais - SERAV da Subsecretaria Especializada em Violência e Família - SUAF da Secretaria Psicossocial Judiciária - SEPSI do TJDFT.

O objetivo desta pesquisa é refletir sobre a leitura do livro: "Mas ele diz que me ama" e compreender como a história da personagem influencia na vivência de violência conjugal de homens. Assim, gostaria de consultá-lo/a sobre seu interesse e disponibilidade de cooperar com a pesquisa.

Para que isso seja possível, serão realizadas duas entrevistas com você e demais participantes com duração de uma hora a uma hora e meia. No primeiro encontro explicaremos os objetivos da nossa pesquisa e pediremos para você que leve para casa e leia o livro "Mas ele diz que me ama" e que responda a um questionário com algumas perguntas sobre as suas percepções sobre o livro. No segundo encontro, você também será convidado/a a participar de uma reflexão em grupo e com outros/as participantes que também já estão em acompanhamento psicossocial no SERAV/NAFAVD. Após conclusão da pesquisa esperamos realizar pelo menos um encontro com você e os/as demais participantes para apresentar e esclarecer os resultados.

Acreditamos que esta pesquisa não acarretará riscos diretos para você. No entanto, caso você ou o pesquisador julgue necessário ou surja problemas emocionais após a entrevista, tais como angústia e ansiedade pelo fato de relembrar e refletir sobre as vivências violentas, será trabalhado no próprio acompanhamento psicossocial em andamento no SERAV/NAFAVD ou por algum encaminhamento à Rede Social parceira do SERAV/NAFAVD. A qualquer momento você pode procurar o pesquisador para atendimento, mesmo após o encerramento do acompanhamento psicossocial no SERAV/NAFAVD. Por outro lado, a sua participação nessa pesquisa pode favorecer a reflexão sobre o seu relacionamento conjugal, sobre as dificuldades em pedir ajuda e lidar com a violência. A sua participação na pesquisa pode trazer benefícios para o seu relacionamento e para a sua vida.

Solicitamos sua autorização para gravação de voz durante o segundo encontro, que será utilizada apenas como complemento de suas respostas ao questionário. Solicitamos também o acesso aos seus dados sociodemográficos do Formulário de Acolhimento do SERAV/NAFAVD. Você receberá todos os esclarecimentos necessários antes, durante e após a finalização da pesquisa, e lhe asseguro que o seu nome não será divulgado, sendo mantido o mais rigoroso sigilo mediante a omissão total de informações que permitam identificá-lo/a. Afirmamos o caráter confidencial e sigiloso de qualquer informação prestada por você na feitura desta pesquisa. O material produzido será guardado em sigilo e sob responsabilidade deste pesquisador. Os resultados poderão divulgados por meios onde a referida tese de doutorado for publicada, tais como artigos científicos, capítulos de livro, dentre outras.

Sua participação é voluntária e livre de qualquer remuneração ou benefício. Você é livre para recusar-se a participar, retirar seu consentimento ou interromper sua participação a qualquer momento. Caso não deseje ou desista de participar desta pesquisa, isso não acarretará penalidade, perda de benefícios ou nenhum prejuízo para você em seu acompanhamento psicossocial no SERAV/NAFAVD e/ou no seu processo judicial.

Você pode entrar em contato com os pesquisadores responsáveis a fim de obter qualquer tipo de explicação, pedir indicação de ajuda profissional caso julgue necessário e/ou para obter informações sobre o andamento da pesquisa. O projeto desta pesquisa foi submetido à avaliação e 
aprovado pelo Comitê de Ética em Pesquisa - CEP/IH/UnB. Você também pode entrar em contato com a Coordenadora do CEP pelo e-mail cep_ih@unb.br

Este Termo de Consentimento Livre e Esclarecido é redigido em duas vias, uma para a guarda do(s) pesquisador(es) e outra para você guardar.

$\mathrm{Eu}$, declaro que aceito participar voluntariamente desta pesquisa. Afirmo ainda, que autorizo a utilização das informações prestadas por mim para este estudo.

Brasília, de de 201_.

Assinatura do/a participante

Assinatura do pesquisador responsável

Pesquisadores responsáveis pela pesquisa:

- Fabrício Guimarães (Psicólogo CRP 01/13650 - Doutorando da UnB mat.11/0166060, psicólogo da SERAV/TJDFT, mat.: 317983). Telefone: (61) 92255200 / 31038434 SERAV.

- Gláucia Ribeiro Starling Diniz (Professora de psicologia da UnB - Orientadora) Telefone: (61) 33072625 - Ramal 315.

\section{Contato com o Comitê de Ética em Pesquisa:}

Você também pode entrar em contato com a Coordenadora do CEP no endereço: Comitê de Ética em Pesquisa do Instituto de Ciências Humanas da Universidade de Brasília, Campus Universitário Darcy Ribeiro, ICC - Centro mezanino, Departamento de Serviço Social, Sala B1 432, Brasília, DF, CEP 70910-966 ou pelo e-mail cep_ih@unb.br 